\title{
Mangrove crabs diversity as bio- indicator for the ecology of mangrove ecosystem at Gam Bay-Sawinggrai Research Station, Raja Ampat, Papua
}

By John Dominggus Kalor

Student ID/Email: 20852979/john_pela@yahoo.com

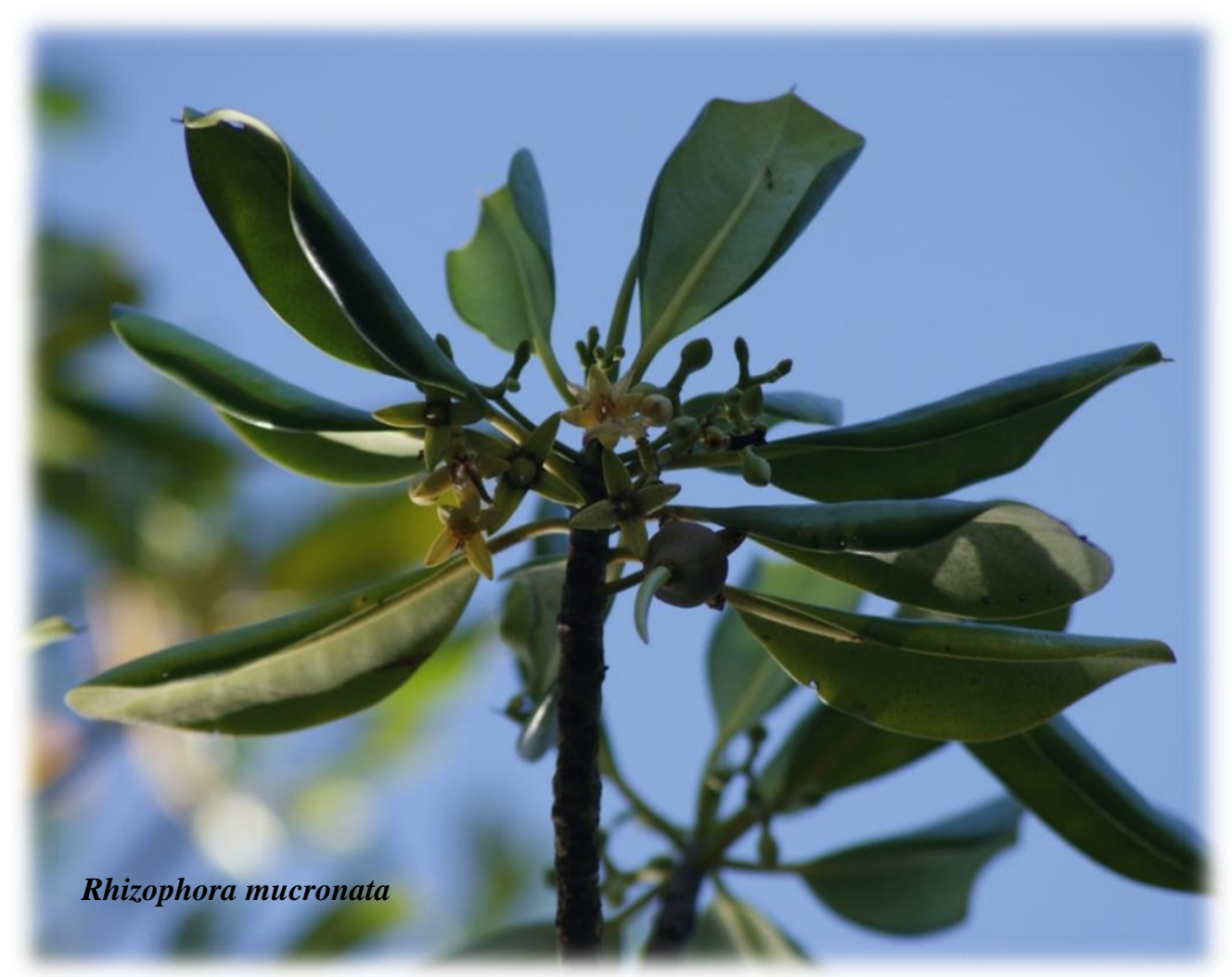

Thesis of Master of International Nature Conservation, March 2012

The Center for Nature Conservation, Department of Conservation Biology, Faculty of Biology, Georg-August University of Goettingen- Germany

The Isaac Center for Nature Conservation, Faculty of Environment, Society \& Design, Lincoln University, CenterburyNew Zealand 
Supervisor/Betreuer

Examiner/Gutachter

Date of Submission/Abgabedatum

German Title/Deutscher Titel
: Prof. Dr. Michael Mühlenberg

: Prof. Dr. Daniel Jackson

: Thursday, March 22, 2012

: Mangrove crabs diversity as the bio-indicator for the ecology of mangrove ecosystem at Gam Bay-Sawinggrai research station, Raja Ampat, Papua 


\section{Abstract}

This study about mangrove crabs diversity as bio-indicator for the ecology of mangrove ecosystems was established at Gam Bay-Sawinggrai Research Station, Raja Ampat, Papua, from $2^{\text {th }}$ May- 11 June 2011. In order to indentify the number of crab diversity and density, and then to describes the mangrove crab diversity as the bio-indicator for assessing the current ecological conditions of mangrove ecosystems. By using the point transects, quadrat, point center quarters, stratify transects design, and the rank of disturbances at 10 stations, 40 transects, 160 points, and 160 quadrats. As the results: 5 families, 9 genus, 15 species of true mangrove tree, the total individual is about 585, and then 10 families, 10 genus, 11 associated mangrove species, total individual 38 have recorded. We gets Shannon-Wiener index is about 2.411, and the Simpson index is 0.854, and the Margalef index is 3.884. However, Ceriops decandra is the new species, therefore the numbers of mangroves diversity in Raja Ampat should change became 26 species. Gam Bay preserves 4 super families, 7 families, 12 genus, and 53 species of mangrove crab, and the total population is about 2846 individual, and we had Shannon-Wiener index is about 4.823, Simpson index is 0,954, and Margalef is 6.538. On the whole we had high diversity and richness of mangrove crab and mangroves trees in Gam Bay. The linear regression analysis and Pearson's index shows, mangroves diversity and crabs community (diversity, richness, and density) have significant relationship. Therefore we are going to reject $\mathrm{H}_{0}$ and accept $\mathrm{H}_{1}$. The high diversity, richness, density of mangrove crabs indicates a mangrove ecosystem has low density, high diversity and richness of mangrove trees, and also high diversity of crab habitats, this is appropriate for the coastline mangrove ecosystem. While, low diversity, richness, density of mangrove crabs indicates a mangrove ecosystem has high density, low diversity and richness of mangrove trees, and low diversity of crab habitats, this is suitable for the riverine mangrove ecosystem. The islands and the coves mangrove forests are compatible for both typical of ecological and biological correlation. Therefore crab diversity as the biological indicator is useful to describe the ecological conditions of particular mangrove forest area. The contribution of Ocypodidae and Sesarmidae crabs as the greatest population is significant on these relationships. But the future researchs needed, in order to compare this conclusion with other location which has high or moderate level of disturbances and to clarify the relationship between the diversity and density of mangrove trees and crabs density. We verified mangrove ecosystems still capable to provide a suitable fundamental niche for mangrove crab species, the current disturbances in Gam Bay are under the carrying capacity, yet the integrity and stability of mangrove ecosystems are secure from being degradation.

Key Words: Mangroves, Crabs, Bio-indicator, Ecology, Gam Bay, Raja Ampat. 


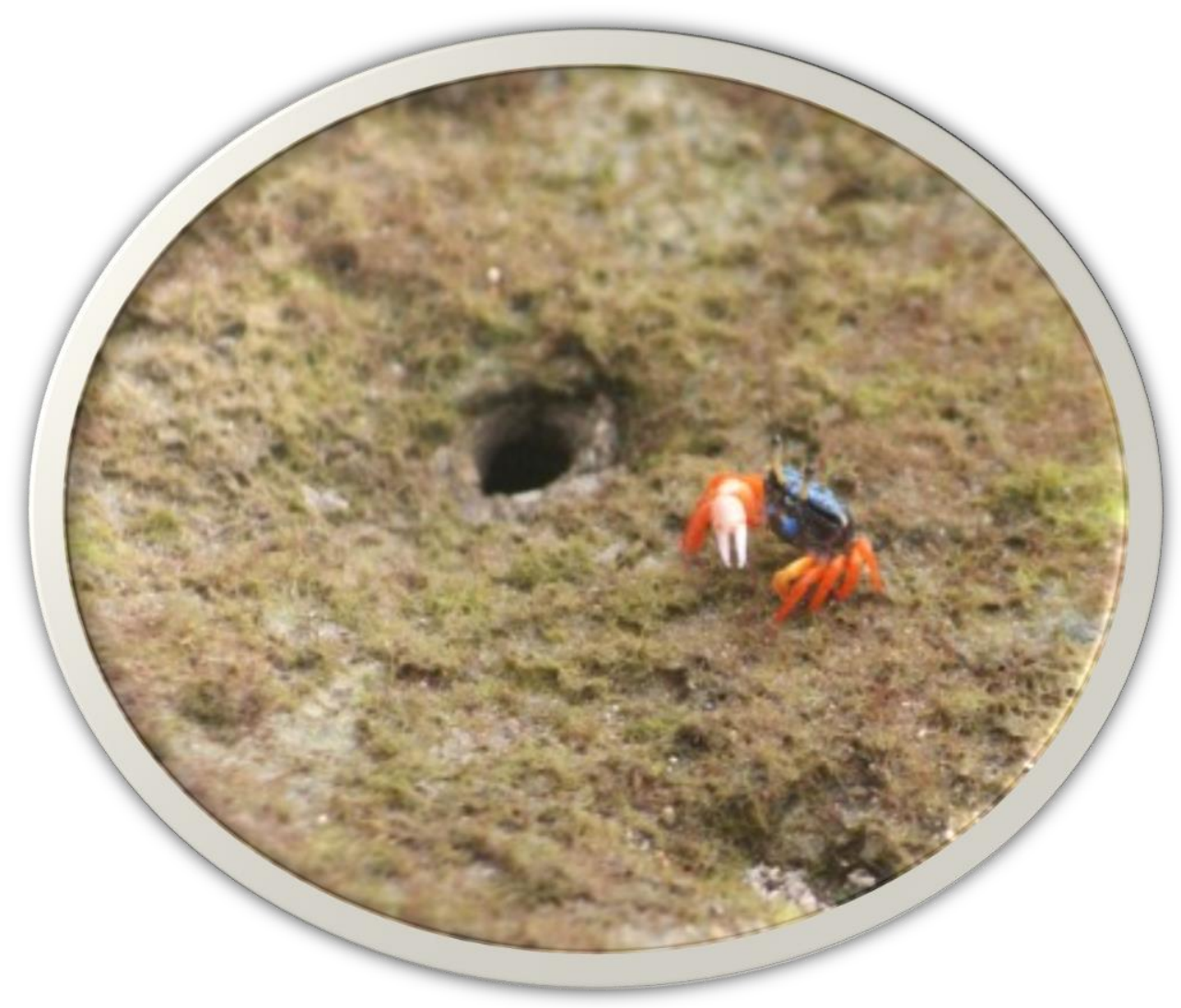

Uca sp 17/ Uca tetragonon (Herbst, 1790) 


\section{List of Contents}

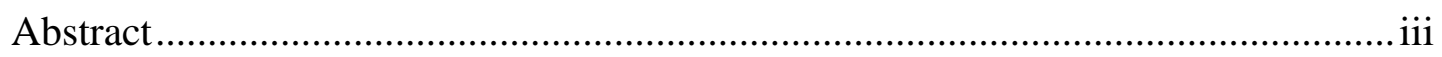

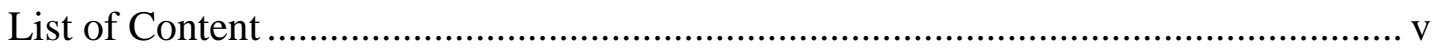

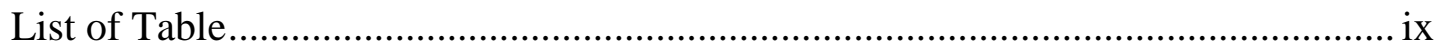

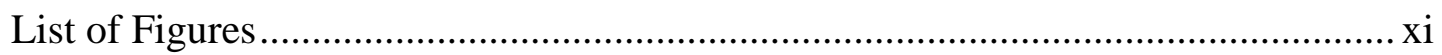

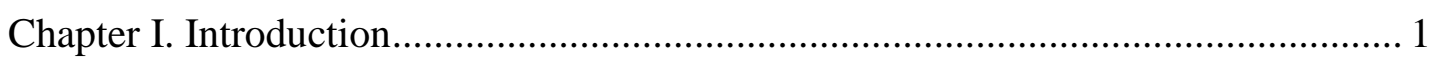

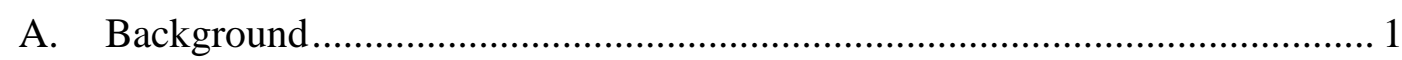

B. Research Objectives............................................................................. 3

C. Hypothesis and Specific question ...................................................... 4

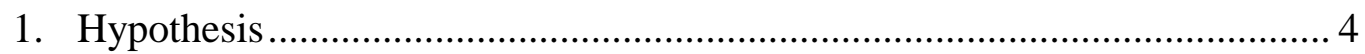

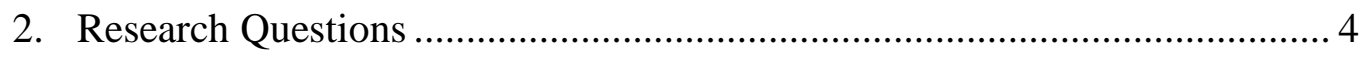

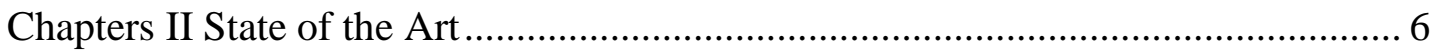

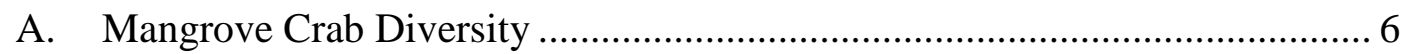

B. Ecological Relationship between Mangrove Crabs and Mangrove Ecosystem7

C. The Bio- Indicator for the Integrity of the Mangrove Ecosystem ................. 10

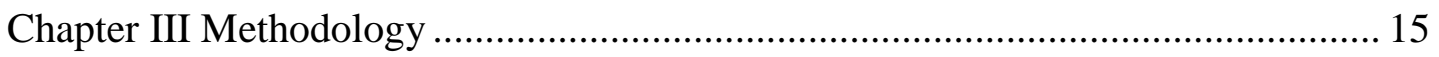

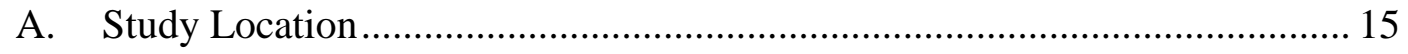

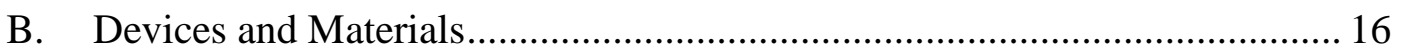

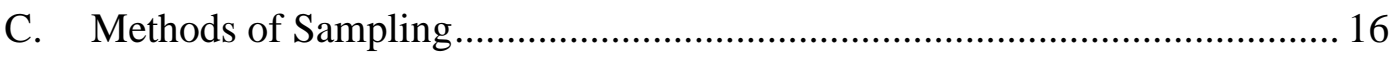

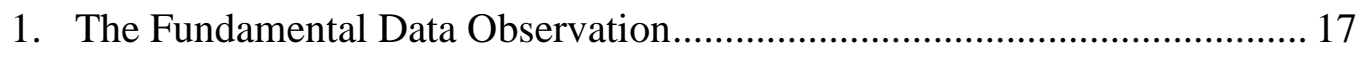

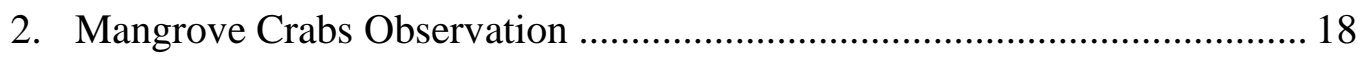

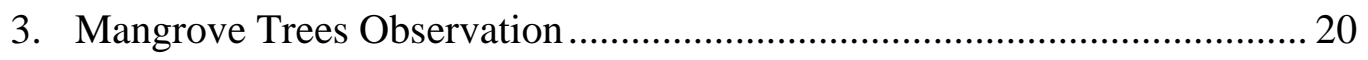

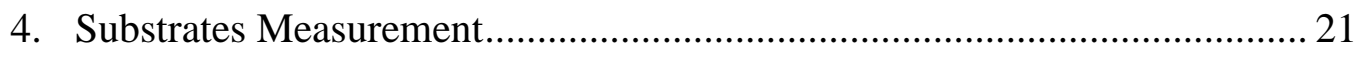

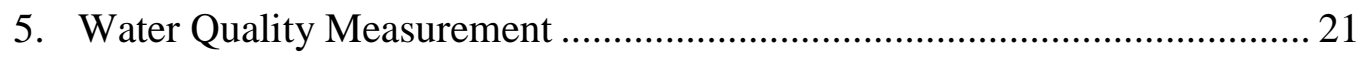

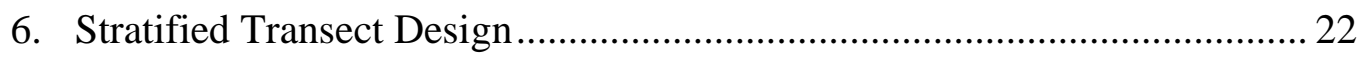

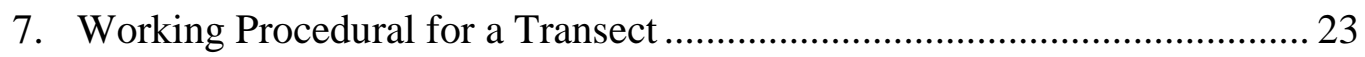

D. The Procedure of Mangrove Crabs and Mangrove Trees Identifications...... 24

1. The Procedure of Mangrove Crabs Identification....................................... 24 
2. The Procedure of Mangrove Trees Identification ....................................... 25

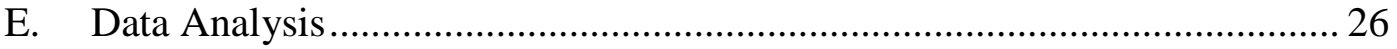

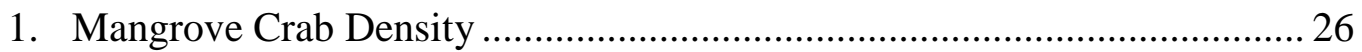

2. Shannon-Wiener Index (Krebs, 1985) ……............................................ 27

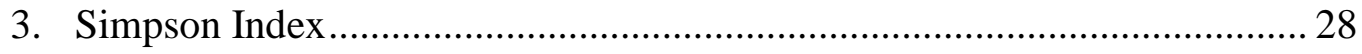

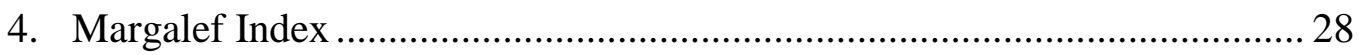

5. Point Center Quarter Analysis ............................................................. 29

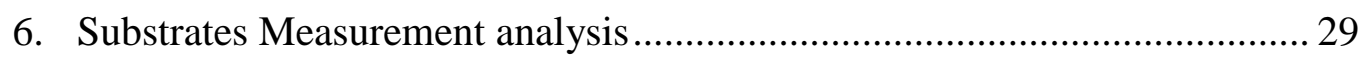

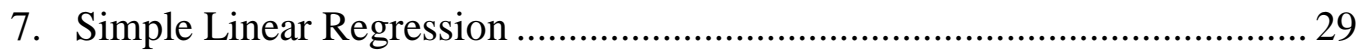

8. The Ranks of Disturbances at 10 Stations...................................................... 30

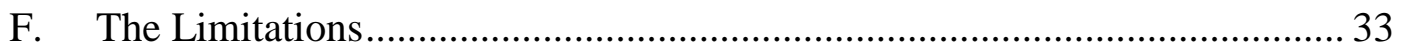

1. The High and Low Tide of Sea Water ....................................................... 33

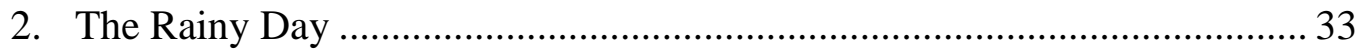

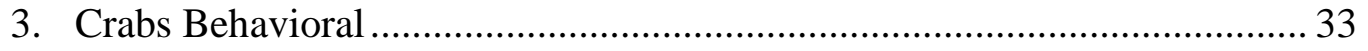

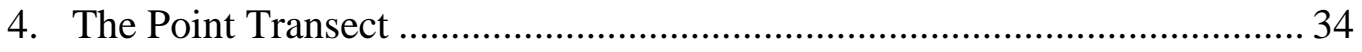

5. No Data about Crab Diversity in Raja Ampat ........................................... 34

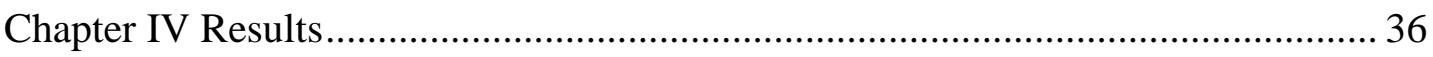

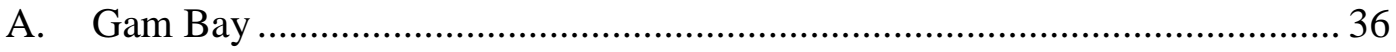

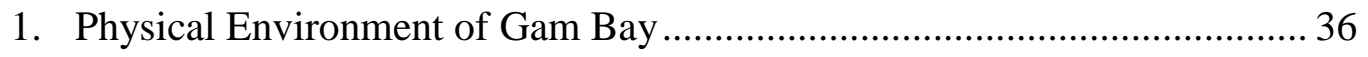

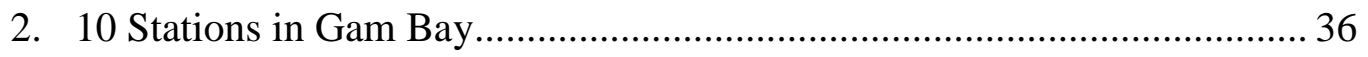

3. The Level of Disturbances in Ten Stations of Gam Bay ............................ 38

B. Mangrove Ecosystem and Crabs Habitat in Gam Bay, Raja Ampat Islands. 39

1. Mangrove Ecosystem in Gam Bay, Raja Ampat Islands ............................ 39

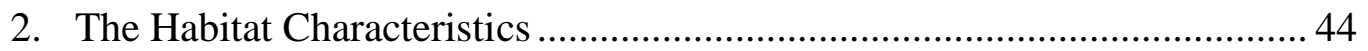

C. Mangrove Tree Community in Gam Bay, Raja Ampat Islands.................... 46

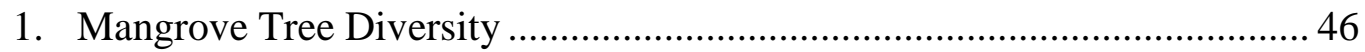

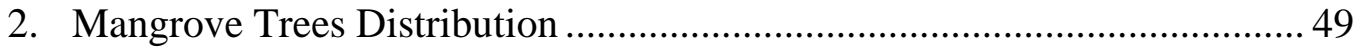




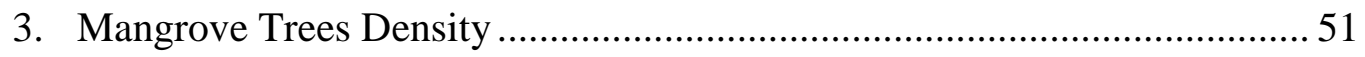

D. Mangrove Crabs Community in Gam Bay, Raja Ampat Islands................... 53

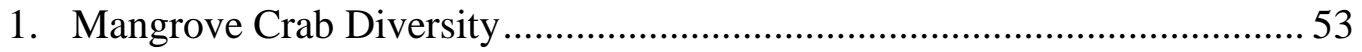

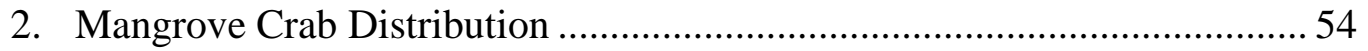

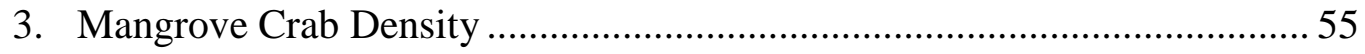

4. The Associated Crab Species in a Micro-habitat ........................................ 61

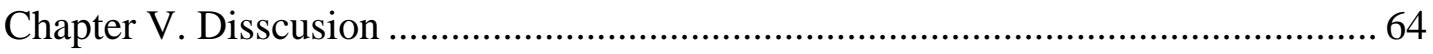

A. Mangrove Ecosystem in Gam Bay: The Diversity of Crab Habitat and

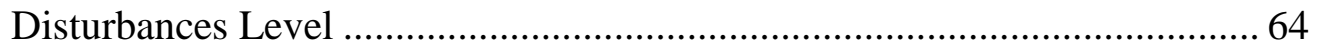

1. The Diversity of Crab Habitat and the Cluster of Mangrove Ecosystem in

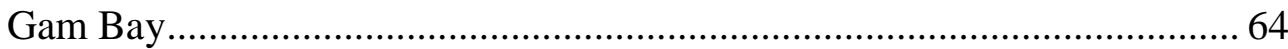

2. The Disturbances of Mangroves Ecosystem in Gam Bay ........................... 67

3. The Disturbances Factors in Gam Bay: the Remoteness as the Indirect

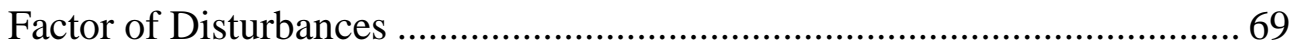

B. The Community Ecological Association among Mangrove Crabs and

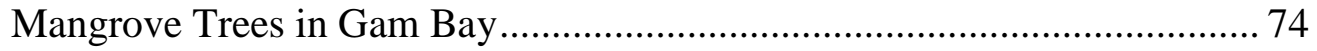

1. The Association between Mangroves Diversity and the Mangrove Crabs Community: Diversity, Richness, and Density .75

2. The Association between Mangroves Richness and the Mangrove Crabs Community: Diversity, Richness, and Density 84

3. The Association between Mangroves Density and the Mangrove Crabs Community: Diversity, Richness, and Density

C. Mangrove Crab as the Biological Indicator for the Ecology of Mangrove Ecosystem at Gam Bay 95

1. The Criteria of Good Indicator Ability of Mangrove crabs ........................ 96

2. The Criteria of Abundant and Common......................................................... 97

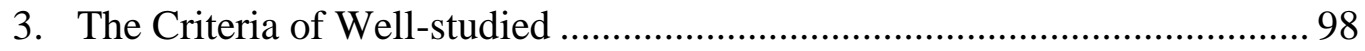

4. The Criteria of Economically/ Commercially …......................................... 99

Chapter VI. Conclusions and Recommendations .............................................. 101 


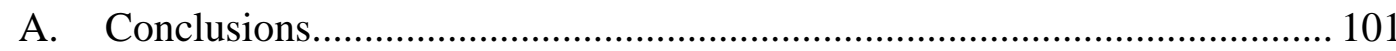

1. The Current Conditions of Mangrove Ecosystems in Gam Bay ................ 101

2. The Relationship between Mangroves Community and Mangrove Crabs Community (Diversity, Richness, and Density) ...................................... 102

3. Mangrove Crabs as Bio-Indicator for the Ecology of Mangrove Ecosystem

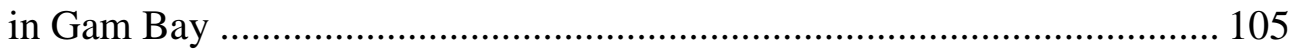

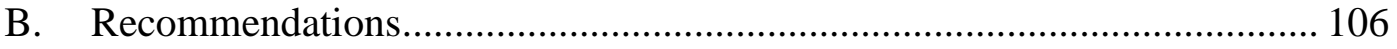

1. Recommendation for the Future Research ............................................... 106

2. Conservation Approaches: How to conserve the Crabs and Mangrove

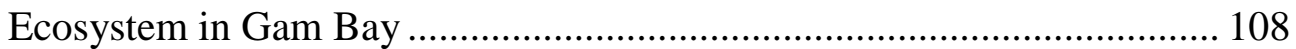

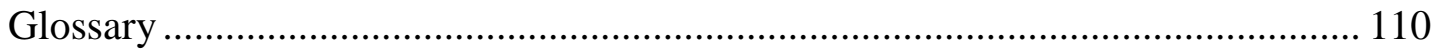

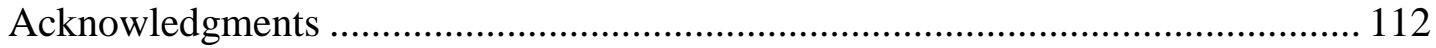

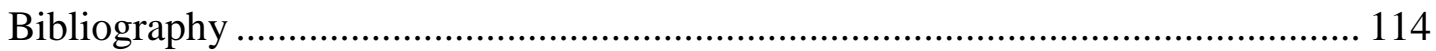

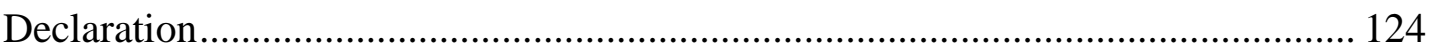

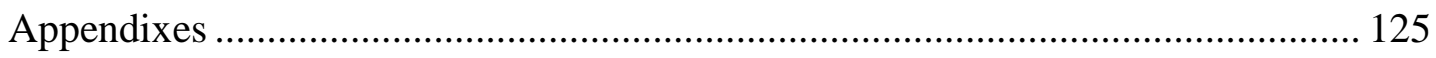




\section{List of Tables}

Table 1. The Rank of Distances from the human population to Station.....................30

Table 2. The Ranks of Rubbish Availability in a Station ..........................................31

Table 3. The Ranks of Cutting Trees Activíties for the Constructions Material

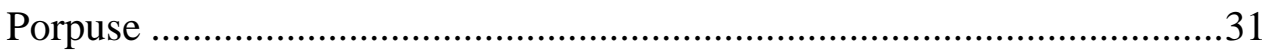

Table 4. The Rank of Gardening Activity ................................................................

Table 5. The Rank of Transportation Activities ........................................................32

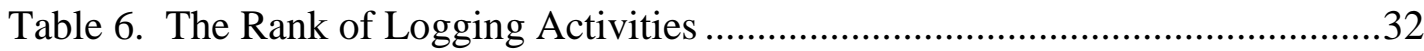

Table 7. The Ranks of Station Disturbances ..................................................................33

Table 8. The Coordinates Position of Ten Stations in Gam Bay ..............................37

Table 9. The Level of Disturbances in Ten Stations in Gam Bay ..............................38

Table 10. The Areas Occupied by Mangrove Forest in Raja Ampat..........................40

Table 11. The Physical Characteristic in the Ten Stations in Gam Bay .....................44

Table 12. The Diversity of True Mangrove Species..................................................46

Table 13. The Diversity of Mangrove Associate Species........................................47

Table 14. The Diversity Values of Mangrove Tree Species.......................................48

Table 15. The Distribution of the True Mangrove and Mangrove Associated Species at Ten Station in Gam Bay.....................................................................50

Table 16. The Density Value of Mangrove Trees .....................................................52

Table 17. Diversity of Mangrove Crab Species.........................................................53

Table 18. The Diversity Value of Mangrove Crab Species.......................................54

Table 19. The Distribution of Mangrove Crab Species at Ten Station in Gam Bay .56

Table 20. Mangrove Crabs Density at Ten Stations in Gam Bay..............................58

Table 21. The Numbers of Associated Mangrove Crab Species in Micro-habitat....62

Table 22. The Variety of Mangrove Crabs Habitat in Gam Bay ..............................65

Table 23. Mangrove area in Raja Ampat and Others .............................................68

Table 24. The Relationship of Disturbances Factors ................................................70

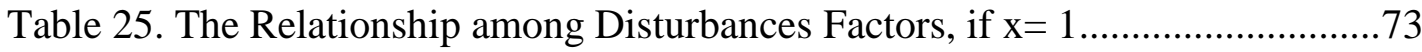

Table 26. The Relationship among the Mangrove Diversity and Crabs Community:

Diversity, Richness, and Density ................................................................ 75

Table 27. The Relationship among Mangrove Diversity and Mangrove Crabs: if $\mathrm{x}=$

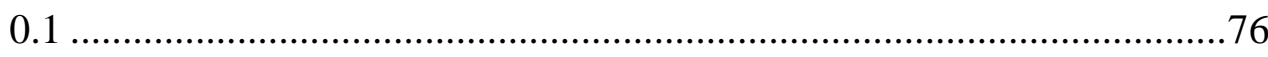


Table 28. The Relationship among Mangrove Diversity and Mangrove Crabs:

Predicted Value of Mangrove Crabs Community, if $x=-0.1$ .77

Table 29. The Relationship among the Mangrove Richness and Crabs Community:

Diversity, Richness, and Density. .85

Table 30. The Relationship among Mangrove Richness and Mangrove Crabs: if $\mathrm{x}=$ 0.1 .85

Table 31. The Relationship between Mangrove Density and Mangrove Crab Community: Diversity, Richness, and Density .87

Table 32. The Relationship among Mangrove Density and Mangrove Crabsif $x=0.1$

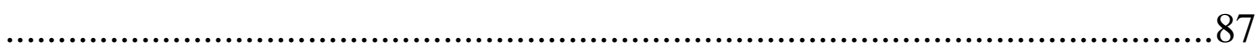

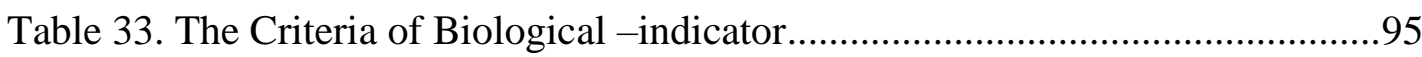

Table 34. The Status of The Relationship between Mangrove Community and Crab

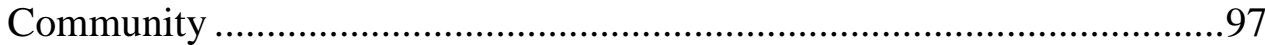

Table 35. Review the Criteria of Biological -Indicator ........................................105 


\section{List of Figures}

Figure 1. The Study Location in Gam Island at Raja Ampat Island.......................... 15

Figure 2. Point Sampling Method........................................................................ 18

Figure 3. The Quadrats Sampling on a Transect Line ........................................... 19

Figure 4. The Point Center Quarters ..................................................................... 20

Figure 5. The Stratified Transect Design ................................................................ 22

Figure 6. Ten Sampling Station at Gam Bay ......................................................... 37

Figure 7. The Camparison of Mangroves Diversity in Gam Bay …......................... 48

Figure 8.Mangroves Availability at Stations in Gam Bay ..................................... 51

Figure 9. Average of Mangrove Crab Density at Ten Station ................................. 57

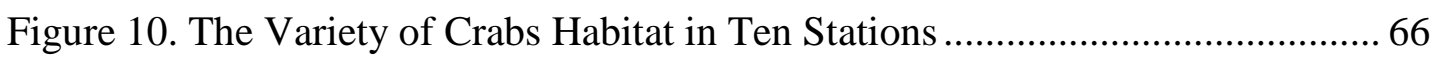

Figure 11. The Comparison between the Type of Mangrove Ecosystem and the Average Numbers of Crabs Habitat ...................................................... 66

Figure 12. The Level of Disturbances at Ten Stations in Gam Bay Area ................ 69

Figure 13. The Relationship among the Distances and Disturbances Factors:

Rubbish, Harvesting for the Construction Material Uses, Traditional

Garden, Transportation Activity, and Logging Activity .....

Figure 14. Distances as Indirect Disturbance Factor significantly affected Others

Disturbances Factors

Figure 15. The Comparison between Mangroves and Crabs diversity in Mangrove

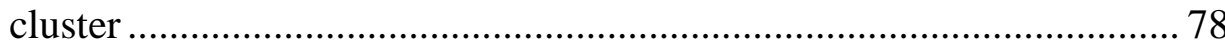

Figure 16. The Home Range of Crabs Species at Ten Station in Raja Ampat .......... 80

Figure 17. The Relationship between Habitat Diversity and Crabs Community: Crab Diversity, Richness, and Density 82

Figure 18. The Relationship between Mangroves Richness and Crabs Community: Crab Diversity, Richness, and Density 86

Figure 19. The Relationship between Mangroves Density and Crabs Community: Crab Diversity, Richness, and Density ..... 89

Figure 20. The Relationship between Habitat Diversity and Crabs Community: Crab Diversity, Richness, and Density 92

Figure 21. The Numbers of Mangrove Crabs Species are often appear together at Ten Station in Gam Bay Area 93 
Figure 22. The Relationship between Mangrove Density and the Numbers of Species which have Interaction Ability.

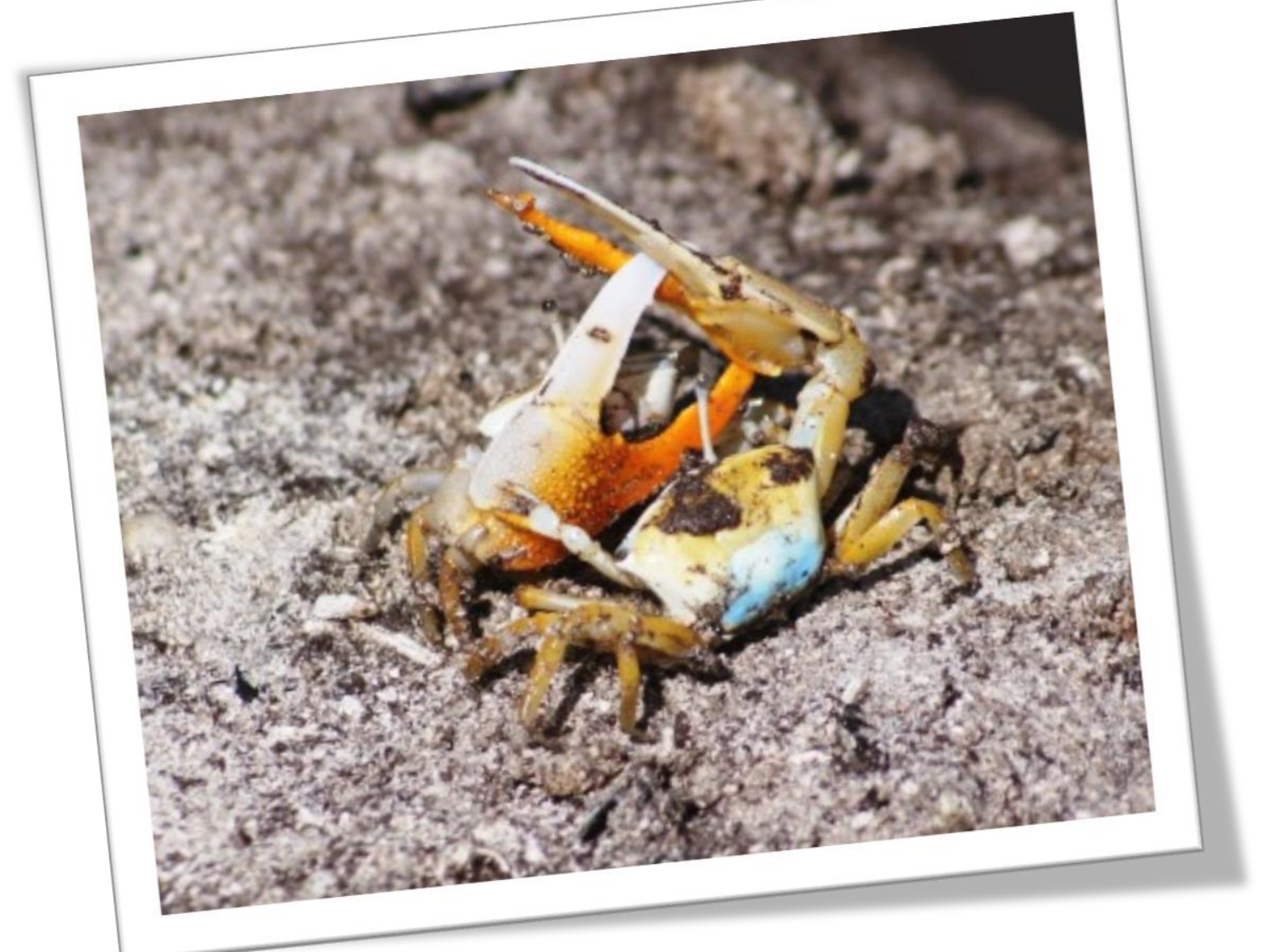

Two males of Uca spp 19/U. jocelynae fighting 


\section{Chapter I. Introduction}

\section{A. Background}

Raja Ampat or "the Four Kings" is located at the Head Bird of Papua Island. This region is surrounded by the sea encompasses approximately 40,000 km2 (McKenna, 2002) and other authors say about 45,000 km2 (Ainsworth, et al., 2008), these islands are consist of approximately 610 islands (Ainsworth, et al., 2008). Raja Ampat has highest numbers of marine biodiversity worldwide (McKannan et al., 2002; Bailey, 2003; Nature Conservancy, 2003; Allen \& Erdmann, 2009; McLeod, et al., 2009; CII, 2010).

The Raja Ampat biodiversity had been explored since many years a go, according to (McKannan et al., 2002; Allen \& Erdmann, 2009). At the present Raja Ampat biodiversity as follow, 699 species of mollusks (McKenna et al., 2002), 535 species of coral reefs (Veron \& Turak, 2006), about 1.149 species coral reef fishes (McKenna et al., 2002), and 4 species of sea turtle (Nature Conservancy, 2003), and 25 species of the true mangrove trees (Nature Conservancy, 2003). There is no research at all about mangrove invertebrates (Alongi, 2007), and yet on the book of “The Ecology of Papua, Part One” by Adrew J. Marshall and Bruce M. Beehler (2007) there are no explanation about how many mangrove invertebrate nor mangrove crabs. This is the first research of mangrove crabs in Raja Ampat, and through this research, it is hoped that the total number of biodiversity in Raja Ampat and also Papua region will be increased.

The types of ecosystems in the Raja Ampat could be divided into two major groups, such as the terrestrial ecosystems and marine ecosystems (Nature Conservancy, 2003). Mangrove forest ecosystem is positioned in between both groups of ecosystems, exactly in transitional zone, which means in between land and the sea (Echeverria-Saenz, et al., 2003). Ecologically, the function of mangrove forest is to maintain entire integrity of the seashore, it was including sea grass ecosystem, coral reef ecosystem, estuary ecosystem, and small island ecosystems (McKannan et al., 2002; Schwamborn et al., 2002; Ashton et al., 2003; Nature Conservancy, 2003; Soundarapandian, 2008). On the other hand, the mangrove ecosystem is provided several economical values and used for local people (Ashton et al., 2003), called ecosystem services. Yet ecologically, this 
ecosystem have complex environment, provides fundamental niche, such as numerous habitat, food and resources for many flora and fauna, it was including mangrove crabs.

Mangrove crabs live in mangrove ecosystem and distributes to the following mangroves habitation, such as along coastal line, river, delta, basin, and estuaries area (Macintosh \& Ashton 2002; Ashton, et al., 2003; Mazumder \& Saintilan, 2003; Amarasinghe, 2009). Mangrove crabs are "the ecosystem engineer" (Nordhaus, 2003; Gillkin and Kamanu, 2005; Amarasinghe, 2009) and "the keystone" (Mazumder \& Saintilan, 2003; Gillikin, et al., 2004; Amarasinghe, 2009) of mangrove ecosystem. Hence mangrove crabs are playing very important roles for the structure and function of the mangrove ecosystem itself (Macintosh \& Ashton 2002; Ashton, et al., 2003; Mazumder \& Saintilan, 2003; Amarasinghe, 2009) and they was affect the wide range of mangrove organisms (Mcivor \& Smith III, 1995; Schwamborn et al., 2002; Nordhaus, 2003; Soundarapandian, et al., 2008; Amarasinghe, 2009). On the other hand these crabs also have economical, commercial, and cultural value (Soundarapandian, et al., 2008), for example, Scylla serrata, S. paramamosain, S. transquebarica and S. olivacea, S. oceanica, (Macintosh \& Ashton 2002; Geisen, et al., 2007; Rangka, 2007; Bonine et al., 2008).

Unfortunately, the mangrove ecosystems are often be the victims of particular decision maker for infrastructure development (Wells, 2007). Yet Ashton et al. (2003), underline that the importance functions of mangrove forest has often been unappreciated and not adequately valued economically, it result to the lost and the degradation of mangrove extensively. The same situation was occurred in several places in Raja Ampat Islands, for example: Waisai and Waiwo in Waigeo Island. This situation will cause negative impact on mangrove ecosystem and crabs itself, and we will lose unknown crabs species, therefore it is necessary to do crabs observation and conservation as soon as that possible. Base on the explaination above this research has established in the mangrove forest ecosystem at Gam Island, Raja Ampat.

Mangrove ecosystem and mangrove crab needed much attention (Kathiresan \& Bingham, 2001; Alongi, 2007), due to those subjects become extremely important and have been proposing to be studies, especially about the relationships between biodiversity and the ecosystem functioning (Ashton, et al., 
2003). Actually, there are several groups of crabs are found in Raja Ampat Island too, such as sea grass crabs, coral reef crabs, land crabs, and freshwater crabs. Yet each group might be provides different crab species enormously, it is very attractive and interested on the future research. However, within this research we going to figure out the mangrove crab diversity as the bio-indicator for the integrity of mangrove forest ecosystem.

\section{B. Research Objectives}

This understandable too, that the morphology and characteristic of mangrove ecosytem is very different with other ecosystems, due to this ecosystem was occurred in extreme environment conditions. The common zonation of seashore, starting from indland to the coastal, following the first ecosystem is terrestrial vegetation, coastal vegetation, and next ecosystem is mangrove forest, after that sea grass ecosystem, and finally coral reef ecosystem. All of those ecosystems are continued, connected, and interidenpendent. These ecosystems have very strong relationship. Many scientist proved that the mangrove ecosytem is extraordinary important for whole ecosystem in the seashore, includes various organisms. In the same times, globally mangrove forest area is decreasing so fast.

Scientist or researchers have proved that significantly mangrove crabs communities are playing vary important roles. Meanwhile crab has significant contribution to form the ecological stability of mangrove forest ecosystem. However, by use an individual species or genus it was done, in this time we ere use crab diversity to estimate the ecological status of a mangrove ecosystem in a region.

Maintaining the integrity and stability of mangrove forest as an ecosystem in Gam Bay can be done, if there is an assessment of the current status of the mangrove ecosystem. Therefore, the main idea within this research is to study mangrove crabs diversity and to describe their relationship with mangrove ecosystem. In this case we use mangrove crabs diversity as the bio-indicator for assessing the ecological status of mangrove ecosystem.

Through this study we are able to explain the current ecological status of mangrove forest in Gam Bay by use crab community as the bioindicator. The possible hypothesis is mangroves ecosystem in Gam Bay are occupying by different crabs species, density, and abundance. In order to give more description 
of this situation we design the research objectives, are: (1) to indentify the number of crab diversity and density (2) to describe the mangrove crab diversity as the bioindicator for assessing the current ecological status of mangrove ecosystem.

\section{Hypothesis and Specific question}

\section{Hypothesis}

$\mathrm{H}_{0}$ : There is no relationship between mangrove crabs diversity and the ecology of mangrove ecosystem in Gam Bay, Raja Ampat

$\mathrm{H}_{1}$ : There is a relationship between mangrove crabs diversity and the ecology of mangrove ecosystem in Gam Bay, Raja Ampat

\section{Research Questions}

The research questions are following:

a. How many mangrove crab species in Gam Bay?

b. How are the current conditions of mangrove ecosystems in Gam Bay?

c. How does the mangrove crab diversity as bio indicator for the ecological of mangrove forest ecosystem indicate the human impact?

d. How the ecology of mangrove ecosystems does influences the diversity of mangrove crabs?

e. Which relationship does exist between mangrove crab community and the type of mangrove ecosystem?

f. Is there a zonation of different crab species along the flooding gradient?

g. Does the crab species composition follow a certain pattern? 


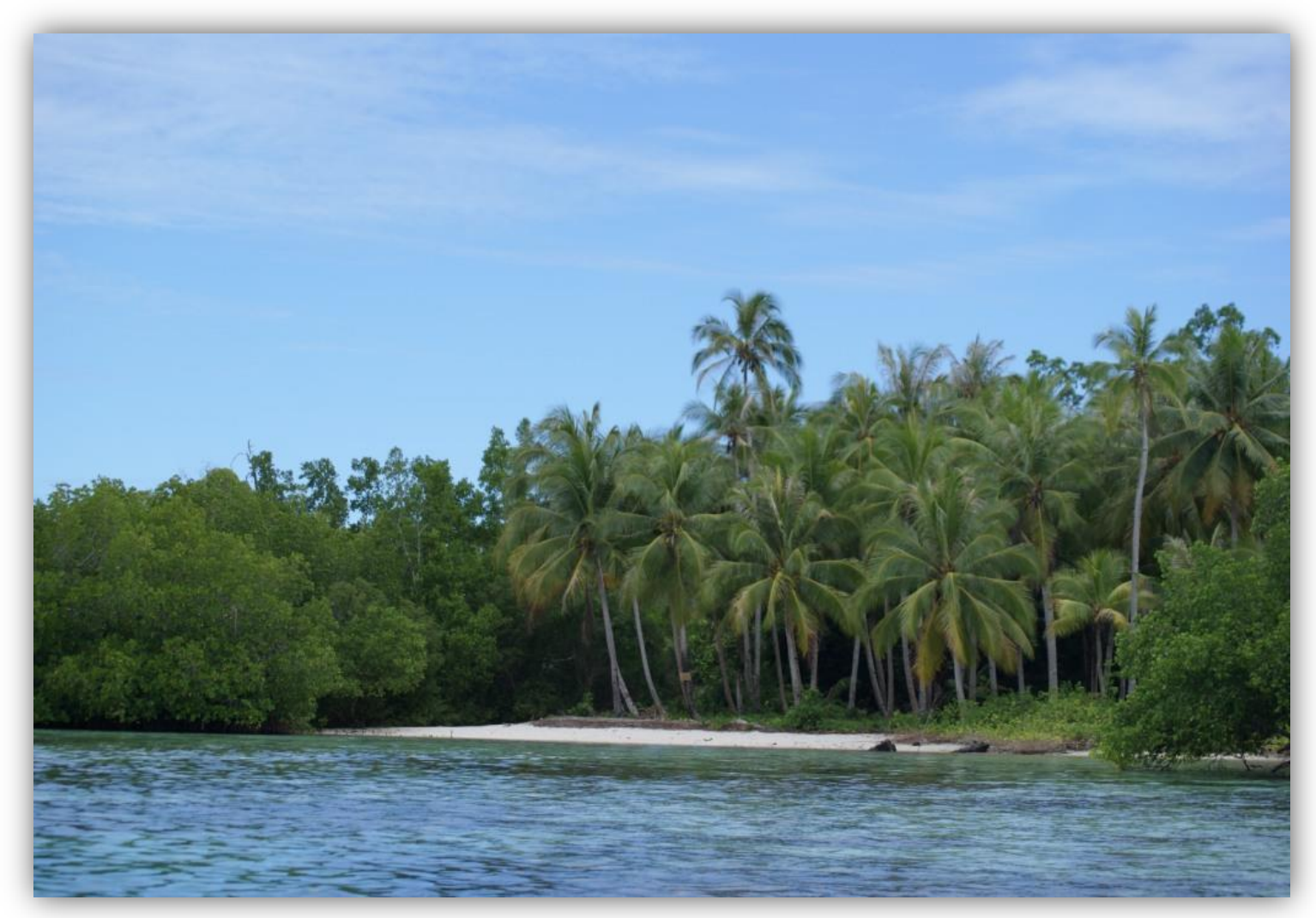

Mangrove Ecosystem at Station Bun Mkun 


\section{Chapters II State of the Art}

\section{A. Mangrove Crab Diversity}

Ng Peter, et al., (2008) in Systema Brachyurorum: Part I. An Annotated Checklist of Extant Brachyuran Crabs of the World, states that the diversity of the brachyuran crabs or the true crabs in worldwide are about 10,500 includes 6,793 valid species and subspecies (with 1,907 primary synonyms), 1, 271 genera and subgenera (with 393 primary synonyms), 93 families and 38 super families. Another statement by His-Te Shih and Ng. Peter K. L., 2011) remark for the number of freshwater crabs species approximately more than 1300 species, 238 genera, and eight families, and they was distributed across tropical and subtropical, such as: Asia, Africa, Central and South America, southern Europe, the Middle East and Australasia. According to Mala Amarasinghe (2009), mangrove crabs diversity itself is very high with estimated 275 species from six families associated with the mangrove ecosystem.

$\mathrm{Ng}$, et al., (2008), believes that the number of crabs species in the worldwide will be increase, that is why he give the estimation the number of crabs about 5,000-10,000 species. Currently, there are many carcinologists still work on crab diversity. Yet they are able to describe numerous new species by observations and taxonomic revisions of brachyuran crabs from different region in the worldwide. It consists of several species from Papua, Indonesia. This fact explains and shows that numerous regions in the world does not have the crab data base, therefore crab observation is needed, then a researcher still have chances to indentify new crabs species, indicated the diversity of crabs still growing.

There are many new species of mangrove crab base on the field observation, for example: Sakaina glabra sp. and S. granulata sp. from the Yellow Sea- China (Jiang Wei \& Liu Ruiyu, 2011a), Paraeuphylax cubanensis, from Matanzas Province- Cuba (Varela \& Schweitzer, 2011b), Paragoneplax chenae sp. from the South (Jiang Wei \& Liu Ruiyu, 2011), Eucolosiana guinoate n. sp. from Vanuatu, Papua New Guinea (Galil \& Ng, 2010), Charybdis (Charybdis) goaensis sp. from Goa, West Coast of India (Vinay, et al., 2010), Sundathelphusa cagayana, a new species from Cagayan Province in Northeastern Luzon Island, Philippines, (Mendoza \& Naruse, 2010) Abyssophthalmus schultzi, Planoprosopon hystricosus, and $P$. rhathamingus, from the Upper Jurassic (Tithonian) Ernstbrunn Limestone- 
Asutria (Schweitzer \& Feldmann, 2009), Geothelphusa makatao, from Southwestern Taiwan (His-Te Shih \& Jhy-Yun Shy, 2009), Macrophthalmus pentaodon, from Bohol Island - the Philippine (Mendoza \& Naruse, 2009), Aphanodactylus panglao, from Panglao Island- the Philippine (Ng \& Naruse, 2009) Pinnixa lata from Otsuchi Bay, Northeastern Japan (Komatsu \& Takeda, 2009a), Heteronucia fujitai from Okinawa Island (Komatsu \& Takeda, 2009b), Sesarma primigenium sp. from the Western Cement Company Cave, parish of St. Elizabeth, Southwestern Jamaica (Collins et al., 2009), and Cryptopilumnus taiwanensis from Taiwan (Pan-Wan Hsueh, 2009).

There are many crabs have described as the new species by using taxonomy revisions, such as: Uca cryptic sp. from Indonesia (Naderloo, et al., 2010), Bonita mexicana from Tortugas Bay, Baja California Sur, México (Campos, 2009), Cymonomus diogenes, $C$. deforgesi, $C$. gracilipes, and $C$. mariveneae, from IndoWest Pasific (Ahyong \& Ng, 2009), Bucculentum bachmayeri, Glaessneropsis myrmekia, G. tribulosa, Lecythocaris obesa, and Prosopon abbreviatum (Schweitzer \& Feldmann, 2009b), Ilyograpsus daviei from Queensland- Australia (Komai \& Wada, 2008), Chiromantes ryukyuanum from Ryuku Island, Japan (Naruse and Ng, P. K. L., 2008).

Some research about crabs (Crustacea: Decapoda: Brachyura) have done in Papua as well (Rahayu, 2003; 2006), and the researchers are identified several new species. For example in 2009, two scientists from the Sciences Institute of Indonesia or LIPI succeed to identify 103 species mangrove crabs from Mimika (Southwestern Papua), yet 15 species of them are the new species. Another researcher from LIPI, Daisy Wowor and Ng, Peter K. L. (2009), describe and identify two new species from Western Papua, Indonesia, such as: Karstarma ardea n. sp. and Karstarma waigeo n. sp., these two new species are founded in Kalepale Cave, Kp. Lopintol, Waigeo Island.

\section{B. Ecological Relationship between Mangrove Crabs and Mangrove Ecosystem}

Mangrove crabs are morphologically, physiologically and behaviorally well adapted to their environment (Brown, 1992; Kathiresan \& Bingham, 2001; Macintosh \& Ashton 2002). Generally, mangrove crabs are spending whole live cycle in the ground of mangroves ecosystem, some of them are migratory species 
from the neighbor ecosystems, such as seagrass and coral reef ecosystem, for example the swimming crab Thalamita crenata (Kathiresan \& Bingham, 2001). These crabs are predominantly herbivores (Brown, 1992, Mcivor \& Smith III, 1995; Kathiresan \& Bingham, 2001; Macintosh \& Ashton 2002; Soundarapandian, 2008) and only views of them are carnivores or predator species (Kathiresan \& Bingham, 2001; Fratini, et al., 2005). Every single individual of these crabs has its own burrow, the burrows generally have two or more openings and form extensive labyrinths of interconnected tunnels and (Kathiresan \& Bingham, 2001; Thongtham \& Kristensen, 2003).

The mangrove crab is one of the predominant animal groups of the mangrove ecosystem, and than ecologically have vey important roles in the structure and function of the mangrove itself (Macintosh \& Ashton 2002; Ashton, et al., 2003; Echeverria-Saenz, et al., 2003; Thongtham \& Kristensen, 2003; Ravichandran, et al., 2007; Soundarapandian, et al., 2008; Amarasinghe, 2009). They are more depending to that ecosystem or have strong relationship (Kathiresan \& Bingham, 2001), within this relationship between both crabs and mangrove ecosystem it shows a mutualistic relationship.

According to Mala Amarasinghe (2009), mangrove crabs are the "ecosystem engineers" they created new habitats and modify the mangrove sediment or substrates (Macintosh \& Ashton 2002; Ashton, et al., 2003; Thongtham \& Kristensen, 2003). The burrowing activity of the crabs, form a complex tunnel like a system of conduits carrying waters or micro-hydrological system, and this tunnel system can alter the topography in the mangrove area, (Soundarapandian, et al., 2008). This tunnel can dissolved nutrients and air to these primarily anaerobic soils (Kathiresan \& Bingham, 2001; Ravichandran, et al., 2007), those roles are also be a conjunction with other benthic fauna like nematodes, polychaetes, and mudskipper (Kathiresan \& Bingham, 2001).

Crab burrows can effectively remove nitrogen from the aquatic ecosystem in the form of gaseous nitrogen (N2) and nitrous oxide (N2O) (Lee, 1989), and can improve oxygen content in soil layer (Amarasinghe, 2009). The changes to the physical, chemical and biological nature of the ecosystem as a result of the presence of crabs together with any other organism (Kathiresan \& Bingham, 2001; Thongtham \& Kristensen, 2003; Soundarapandian, et al., 2008; Amarasinghe, 2009) are collectively called bioturbation (Amarasinghe, 2009). 
Several example are as follows, two burrowing crabs, Neosarmatium meinerti and $N$. smith are significantly contribute to improve structure and functions mangrove ecosystem in Kenyan (Gillikin, et al., 2004). While, Sesarmidae crabs Chiromanthes spp., in mangrove stand in a Hong Kong Tidal Shrimp Pond, has consuming > 57\% daily leaf, declining amount of nitrogen (Lee, 1989). Then, burrowing activities of Uca cordatus improve the oxygenation of deeper sediment layers in a mangrove forest in Northern Brazil (Nordhaus, 2003).

Whereas, part of the nitrates formed may be transported to other parts of the mangrove and become available nitrogen for plant and bacterial growth, this function also may happen by crab activities. For example, Nordhaus (2003) was show up the impact of $U$. cordatus on the litter turnover rate is higher in the IndoWest Pacific region, further more $U$. cordatus population produces large amounts of finely fragmented faeces which is rich in carbon, nitrogen and bacterial biomass.

Mangrove crabs also the "keystone" species by their high abudance and biomass as well (Ashton, et al., 2003; Nordhaus, 2003; Mazimder \& Saintilan, 2003; Gillikin, et al., 2004; Koch, et al., 2005; Amarasinghe, 2009;), because they was forming important links between the primary detritus at the base of the food web (Robertson, 1986; Koch, et al., 2005; Amarasinghe, 2009), consumers of higher tropic levels; they do supplement their diet with mangrove leaves (Brown, 1992; Kathiresan \& Bingham, 2001; Gillikin \& Schubart, 2004; Soundarapandian, et al., 2008). According to Soundarapandian, et al., (2008), mangrove crabs constitute about $80 \%$ of the macrofaunal biomass and can reach densities of $80-90$ animals $/ \mathrm{m}^{-2}$, however Koch reported that detritivorous crabs ( $>95 \%$ fiddler crabs) account for almost $90 \%$ of total benthic macrofauna production in the Caete mangrove (Koch, et al., 2005).

Several publication reported and explained the roles of crab as the keystone species, follow of, Perisesarma spp. have the highest biomass in certain mangrove forest at East Africa (Gillikin \& Schubart, 2004), fiddler crabs biomass was highest in a North Brazilian mangrove Ecosystem (Koch, et al., 2005). The present of 36 species of families Grapsidae and Ocypodidae is the most dominant fauna in Pichavaram Mangrove Ecosystem, South Coast of India, which play a vital role in recycling the nutrients, enhancing decomposition plant material and litter processing (Soundarapandian, et al., 2008). 
The removal and processing of mangrove leaves by crabs, helps to trap the energy stored in these leaves within the mangroves before the tide can carry them away (Gillikin \& Schubart 2004; Ravichandran, et al., 2007; Robertson, 1986). Furthermore, their faecal material potentially contributes to both secondary production via a coprophagous food chain (Gillikin \& Schubart 2004) and reproduction of the mangrove vegetation (Kathiresan \& Bingham, 2001; Ravichandran, et al., 2007). For example, the impact of $U$. cordatus on the litter turnover rate is higher in a high intertidal forest in northern Brazil (Nordhaus, 2003; Nordhaus, et al. 2006), similar to Sesarna meinerti de Man, 1887 and Cardisoma carnifex Herbst, 1794 at Mida Creek, Kenya, East Africa (Micheli, et al., 1991). Furthermore U. cordatus population produces large amounts of finely fragmented faeces which is rich in carbon, nitrogen and bacterial biomass compared to the sediment (Nordhaus, 2003; Nordhaus, et al. 2006)

\section{The Bio- Indicator for the Integrity of the Mangrove Ecosystem}

The biological and the ecological indicators are more complex, because each problem will have different approach based on the level of problems itself, specific purpose, and the current natural condition. Von Bertalanffy in Jorgensen, et al. (2005) characterized the criteria for the selection of ecological indicator for the ecosystem health assessment (EHA) in the terms of four major attributes, this criteria also can be used for the indicator of ecosystem integrity, such as:

1. Progressive integration (which entails the development of integrative linkages between different species of biota and between biota, habitat, and climate).

2. Progressive differentiation (progressive specialization as systems evolves biotic diversity to take advantage of abilities to partition resources more finely and so forth).

3. Progressive mechanization (covers the growing number of feedbacks and regulation mechanisms).

4. Progressive centralization (which does probably not refer to a centralization in the political meaning, as ecosystems are characterized by short and fast feedbacks and decentralized control, but to the more and more developed cooperation among the organisms (the "Gaia", 
effect) and the growing adaptation to all other component in the ecosystem).

According to Jorgensen, et al. (2005), the ecosystem integrity is the ability of an ecosystem to maintain its organization. While, Primack (2006) dicribes the ecosystem integrity is the condition in wich an ecosystem is complete and functional. However, Karr \& Dudley were the first authors who describe the ecological integrity in 1981 (Maurer, 1992). They defined that ecological integrity as the ability of an ecosystem to maintain a balanced, integrated, adaptive community of organisms having a species composition, diversity, and functional organization comparable to that of the natural habitat of the region". Jorgensen, et al. (2005) emphasizes the two aspects of the organizational state of an ecosystem: function and structure, in order to measure the ecosystem integrity. Function refers to the overall activities in the ecosystem and structure refers to the interconnection between the components of the system (Jorgensen, et al. 2005).

The ecosystem integrity would provide the ecosystem stability; the term of ecosystem stability is close to the ability of ecosystem to resits or to defend against disturbances changes. Although it is seems impossible to maintain the stability of ecosystem now days. If, the stability of an ecosystem decline, it never returns to the same situation again. In order to maintain the integrity of mangrove forest ecosystem, an ecosystem investigation is needed to describe the current situation of that ecosystem, within this approach we will know what we have to do for the future conservation approach.

We can measure the ecosystem integrity base on several indices, such as: indices based on indicator species, ecological strategies, the diversity value, and indicators integrating all environments information (Jorgensen, et al., 2005). According to Faber-Langendoen, et al., (2011), there are three levels approach to assess ecological integrity, we undelined one of them is the intensive assessment, because this level has connected to the main idea on this study. The intensive assessment means ,evaluate the condition of individual occurrences using relatively detailed quantitative field indicators. Assessment can be based on indicators that have been calibrated to measure the responses of the system to various disturbances (e.g. indices of biotic or ecological integrity" (FaberLangendoen, et al., 2011). In this thesis we chose the indices based on the diversity value and indicators which is integrating all environments information, and the 
intensive assessment. Therefore, such important information about the integrity of mangrove ecosystem and the mangrove crab diversity to be the bio-indicator are needed.

Mangrove ecosystems have unique and extreme ecological and biological performing (Kathiresan \& Bingham, 2001; Alongi, 2007; Wells, 2007), for examples high salinity, fluctuated low and high tides, high temperatures, various substrates, and anaerobic soil (Kathiresan \& Bingham, 2001; Alongi, 2007). Ashton, et al., (2003) clarifies three environmental factors, they are: temperature, salinity, and rainfall. Those factors are important key determinants that have strong influence over the growth, survival and distribution of mangrove forest (Alongi, 2007). Consequently mangrove tree have capability to perform incredible adaptation strategy (Kathiresan \& Bingham, 2001) such us: reproduction strategy (Viviparous water dispersal- young seedlings), roots development (e.g. modification of aerial roots), Salt-excreting leave through special leaves anatomy and morphology (Alongi, 2007; Muehlenberg, 2011).

There were approximately 80 species of mangrove tree species in the world, belong to 30 genera, and 20 families (Wells, 2007). In New Guinea due to position exactly in between the Australasian and Indo-Malesian center of biodiversity, there were 43 species (Alongi, 2007). Furthermore in Raja Ampat have 25 species of mangrove trees (Nature Conservancy, 2003).

Mangrove ecosystems are important to neighboring ecosystems such as coral reef, sea grass, and terrestrial ecosystems (Akil \& Jiddawi, 1997; Wells, 2007). On the other hand this ecosystem also play very important role to support the life of peoples (Kathiresan \& Bingham, 2001; Alongi, 2007). Then the mangrove vegetation also contributes to habitat complexity and the diversity of associated flora and fauna (Kathiresan \& Bingham, 2001; Taylor, et al., 2003; Alongi, 2007).

The present circumstances showing that habitat modification, destruction, and exploration are growing rapidly, with the consequence that mangroves are being cleared at an alarming rate. For example in Southeast Asia over the past decades, the mangrove forest ecosystems have been declined significantly (Macintosh, et al. 2002). The same situation is happened in Raja Ampat, due to infrastructure development of the new regency and daily use of people (e.g. livelihood, shelter, and timber). Therefore the sooner strategy in order to save the 
mangrove forest it must be done. The first step is to find the way how to evaluate the ecological status of mangrove ecosystem, and the next would be establishing conservation program.

The dominant macro-fauna of mangroves ecosystem in terms of numbers and species are the crustaceans and mollusks, includes crabs (Kathiresan \& Bingham, 2001), crabs itself are predominant species or the dominant species in mangrove forest area (Macintosh \& Ashton 2002; Ashton, et al., 2003; EcheverriaSaenz, et al., 2003; Gillikin \& Schubart, 2004; Koch, et al., 2005; Ravichandran, et al., 2007; Soundarapandian, et al., 2008). Ecological crab is very important for mangrove ecosystem (Thongtham \& Kristensen, 2003; Amarasinghe, 2009). Thus, their diversity and abundance may reflect the status and functions of mangrove forest ecosystems and serve as potential biological/ecological indicators of habitat change in mangroves ecosystem, therefore it wills discus more on this thesis. 


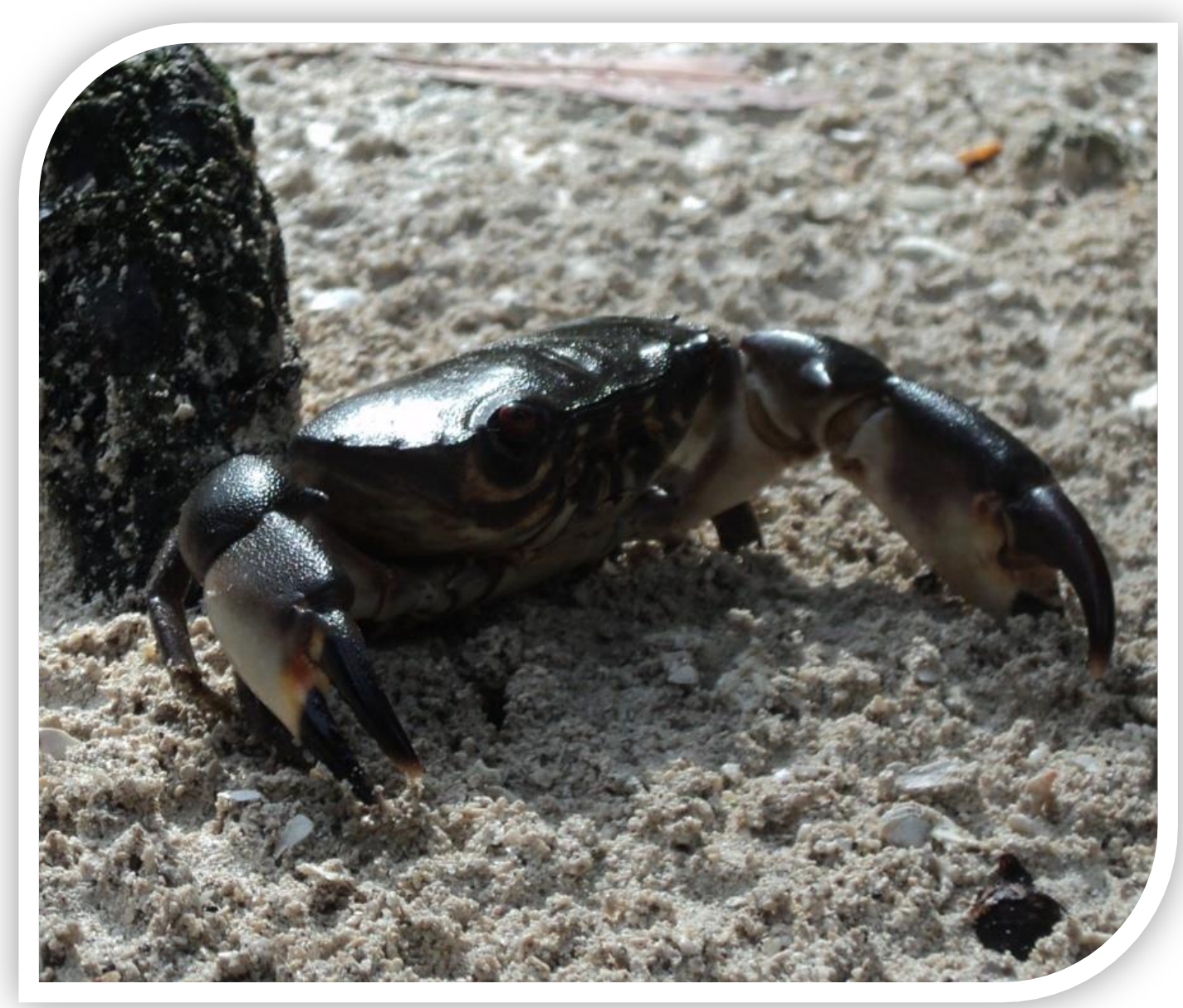

Myomenippe sp at Station Tapor Pandera 


\section{Chapter III Methodology}

\section{A. Study Location}

This study was conducted at Gam Bay on Gam Island in Raja Ampat, from $2^{\text {th }}$ May- 11 June 2011 (See Appendix 1. Time Shcedules). This island is located nearby Southern Waigeo Island, Raja Ampat Archipelago (Picture 01), with coordinates: $\mathrm{S} 00^{\circ} 32^{\prime} 00.7^{\prime}, \mathrm{E} 130^{\circ} 35^{\prime} 08.4^{\prime \prime}$ and $\mathrm{S} 00^{\circ} 29^{\prime} 56.5^{\prime}$ ', E $130^{\circ} 31^{\prime} 47$, 3', There were five villages in this island, such as, Kabui, Yembeser, Yen Wawpnor, Sawinggrai, and Kapisawar (McKenna, et al., 2003: BAPPEDA Kab. Raja Ampat, 2010). Sawinggrai is the oldest village at that island, this village also the location of the Sawinggrai Research Station. This station is managed by the Center for Nature Conservation- University of Goettingen, Germany and Biology Department, Mathematics and Science Faculty of University of Cenderawasih, Jayapura- Papua, Indonesia.

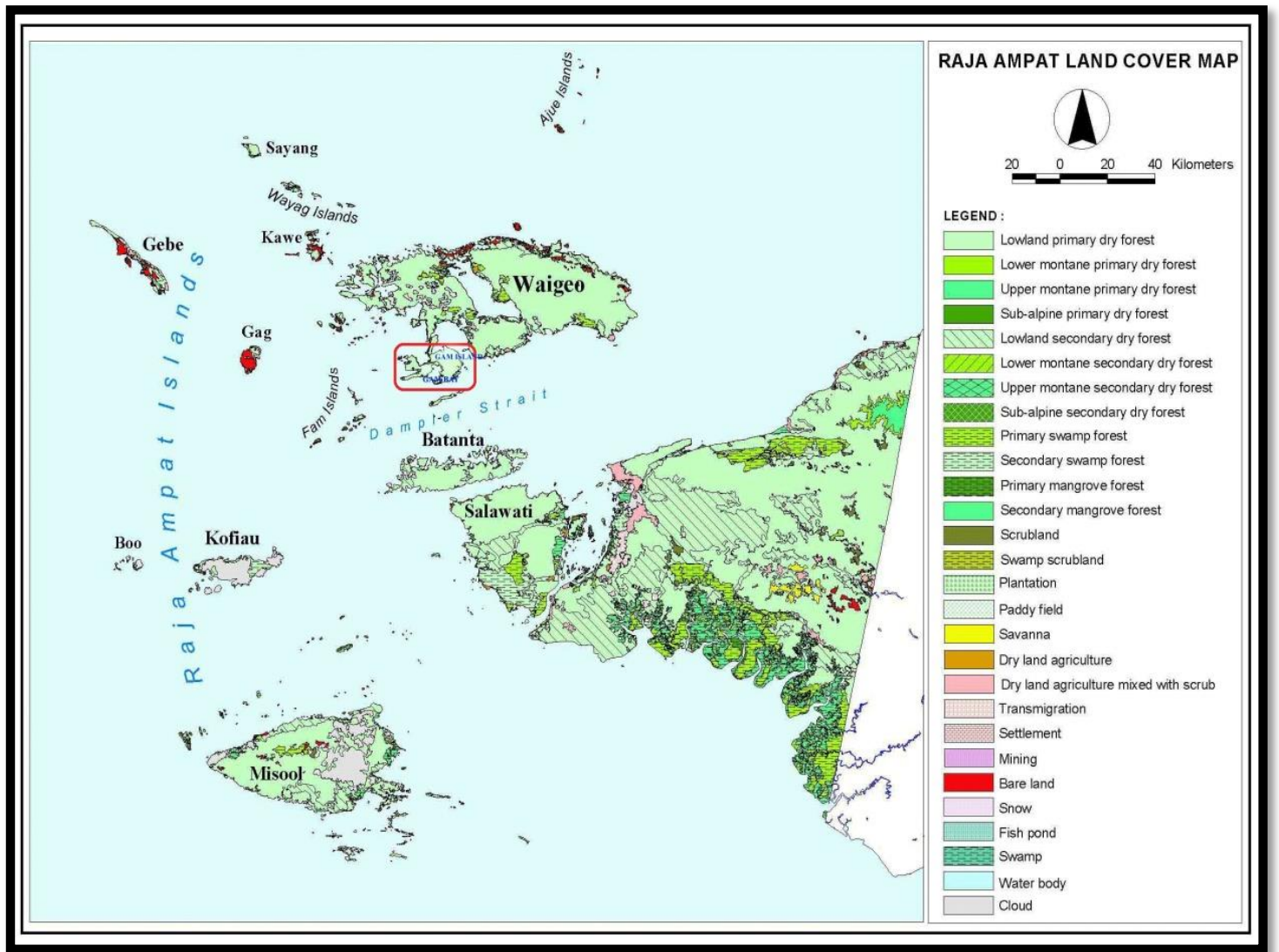

Figure 1. The Study Location in Gam Island at Raja Ampat Island

The Gam Island is marking with a rounded red rectangle; Gam is positioned in the south cost of Waigeo. Resources: CIFWI, 2003 
In general Gam Island is at typical island of the whole region of Raja Ampat Island. This island provides high numbers of marine biodiversity and magnificent natural view. The Red Bir of Paradise (Paradisaea rubra) is an endemic bird in this island. Unfortunately, not too much research has been done in these islands.

\section{B. Devices and Materials}

In conducting this research, we used many devices and several. All devices such as: compass for the angle and the direction measurements of a transect, a rangefinder is for distance measurement, tape measurement $(100 \mathrm{~m}$ and $5 \mathrm{~m})$ for measuring transect length and the substrate deepness, a stick $(2,5 \mathrm{~m})$ for determining the substrate deepness, a global positioning system (GPS) for measuring coordinates, the box specimen for collecting and restoring crab specimen, labelling paper for marking the box specimen, ribbon for marking the line transect, the quadrat $(1 \mathrm{x} 1 \mathrm{~m})$ to observe crabs diversity in their micro habitat, the GLX explorer to measure water quality (with $\mathrm{pH}$ devices, DO devices, and oxygen devices), a salinometer for measure waters salinity, the head lamp for lightness, the camera for making photograph, a set of surgical instruments for specimen preparation, work sheets, the field guide for mangrove tree and mangrove crabs identifications. Materials: formalin for preserving the specimen, aquacades to reduce the formalin concentration.

\section{Methods of Sampling}

There are five steps of this research: (1) collecting the fundamental data or fundamental data observation in the field, such as: physical characteristics of mangrove ecosystem, human influences, and land use, (2) Mangrove crab observation, such as: species, number of individual of species, and distance from crab to the center point, (3) mangrove trees observations in collecting mangrove trees data, such as: tree species and distance from the mangrove tree to the center point, (4) substrate observation, by collecting data of the substrate, such as: type of substrates and deepness of substrates, and (5) observation water quality data, such as: $\mathrm{DO}, \mathrm{pH}$, temperature, and salinity. 


\section{The Fundamental Data Observation}

Before setting up the transect line in particular location for crab and mangrove trees observations, firstly we did the fundamental data observation in the field. The function of this observation is to make sure that the selected stations must be fulfilled by the appropriate variables. Therefore, the fundamental observation is run firstly and then crabs observation.

The advantages of this approach are, the station is selected based on the characteristic of mangrove ecosystem and it is avoided the whole stations have a similarity of characteristics. We can set the transect line and the quadrat a day or two days before the crab observation take a place. In order to run this fundamental data observation we created tree variables, as follows: (1) the location or station it must be big enough to set up four transects lines or the mangrove forest area should not too narrow; (2) the location has to provide various type of substrate or every location or mangrove area has to be dissimilar on substrates. Base on our assumption that the availability of crab species are depend substrates types and mangrove trees community. Within this approach we can avoid the similarity of crab population; (3) the mangrove ecosystems are distributed in various morphological appearances in Gam Bay. Locations of mangrove ecosystem are directly connected with other ecosystem, for example mangrove ecosystem and coral reef ecosystem, mangrove ecosystem and sea grass ecosystem, mangrove ecosystem and costal vegetation, and next mangroves ecosystem and landscape vegetation. On another hand, diverse locations of mangroves ecosystem occurred in Gam Bay, such as: coves, rivers system, small island, and along coastal line; (4) mangrove forest ecosystem area was influenced by human activities, such as: nearby or faraway from a village, rubbish, traditional garden, transportation, cutting tree activities, logging activities and livelihood purpose. Within this strategy by doing fundamental data observation, we are able to count all characteristics of mangrove forest ecosystem in entire Gam Island Bay. Moreover, through this approach would be represented entire mangrove ecosystem characteristic and yet entire mangrove crabs population in Gam Bay. 


\section{Mangrove Crabs Observation}

The two methods has been used for this observation, they are: point transects and quadrate method. Point transect method is a form of distance sampling method (Buckland et al., 1993; 2001; 2006; Thomas et al., 2002). Whereas quadrat sampling to observe the relationship within each species in their micro habitat. These two methods has specific purpose, point transect to observe the crabs diversity, density, abundance, and total population $/ \mathrm{m}^{2}$ (Buckland, et al.,1993; 2001, 2006).

\section{a. Point Transect Method}

In this point transect method, we count three main variables such as: the distance in between detected objects and the center point, the species name, and the number of object are recorded. Detailed attribute for every single transect as follows, length $30 \mathrm{~m}$. and wide $2.5 \mathrm{~m}$. Each line has four sample points, the first sample point exactly in starting point or at point zero, the second point in $10 \mathrm{~m}$, the third point at $20 \mathrm{~m}$, the fourth point at $30 \mathrm{~m}$ (Figure 2). Then, each station has four lines, overall we have 10 stations, 40 lines transects, and 160 sample points.

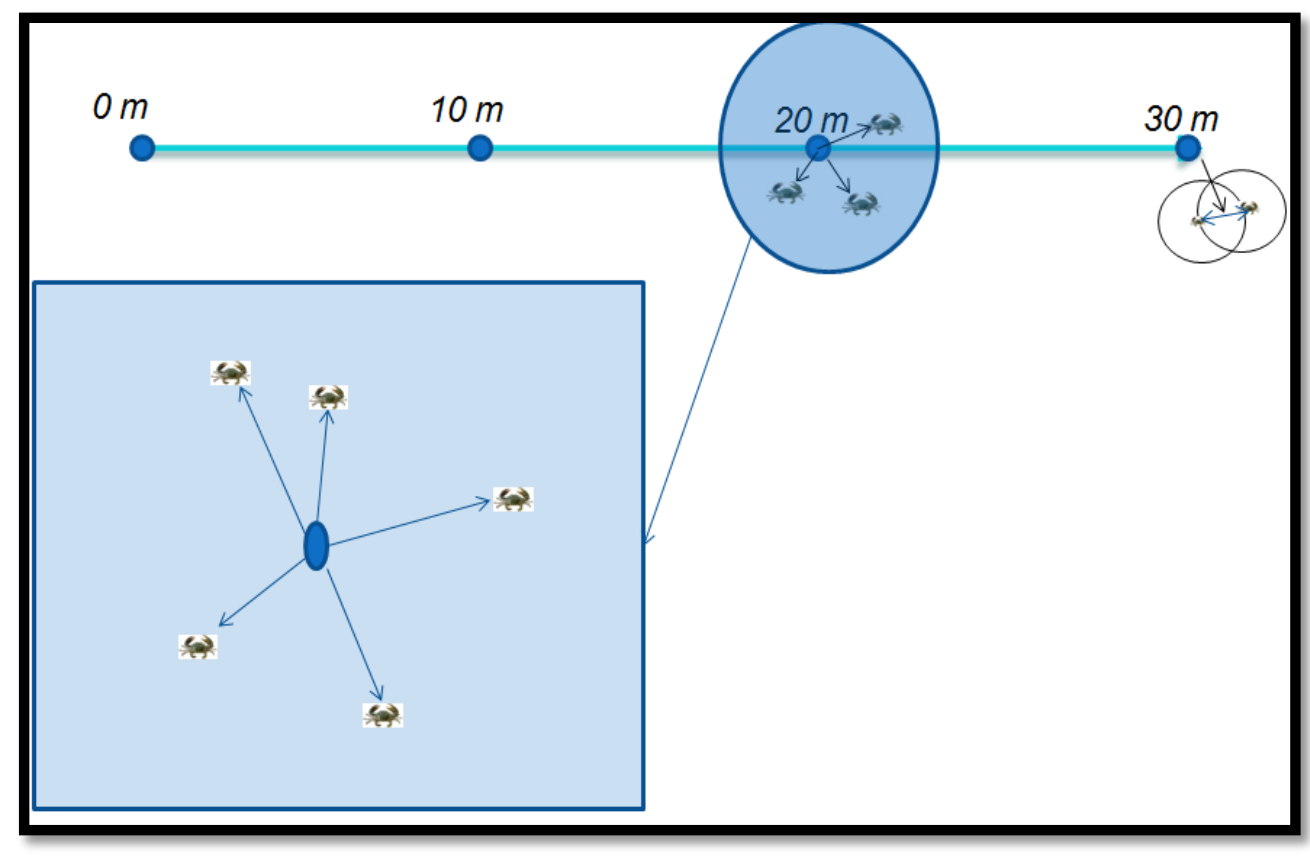

Figure 2. Point Sampling Method

Usually, the distance sampling method has been used successfully and useful in very diverse array of taxa, includes insects, amphibians, reptiles, 
birds, fish, marine and land mammals (Thomas, et al., 2002). In particular the point transect method is usually used for songbird population, even though not exclusively (Thomas, et al., 2002). However, there are no publications concerning that the point transect method has been used for crab observation nor a statement that this method are usefully for crabs observation. Within this research, we are trying to use this method to observe mangrove crab diversity and population (Crustacean; Decapoda; Brachyura).

Understandable, some difficulties might be occurred and founded in the field, yet might be unsatisfying result may happen. However our assumption the point transects method should be worked well for crab observation. Therefore during crab observation in the field we perform very carefully and steps slowly along the line transect, in order to decrease disturbances, noises, and stress circumstances for crabs. On other side we did the observation in the right time when the crab is being active for feeding, foraging, meeting, and fighting. However in this observation we did the observation at low tide during the day, around 09.30 AM to 18.00 PM.

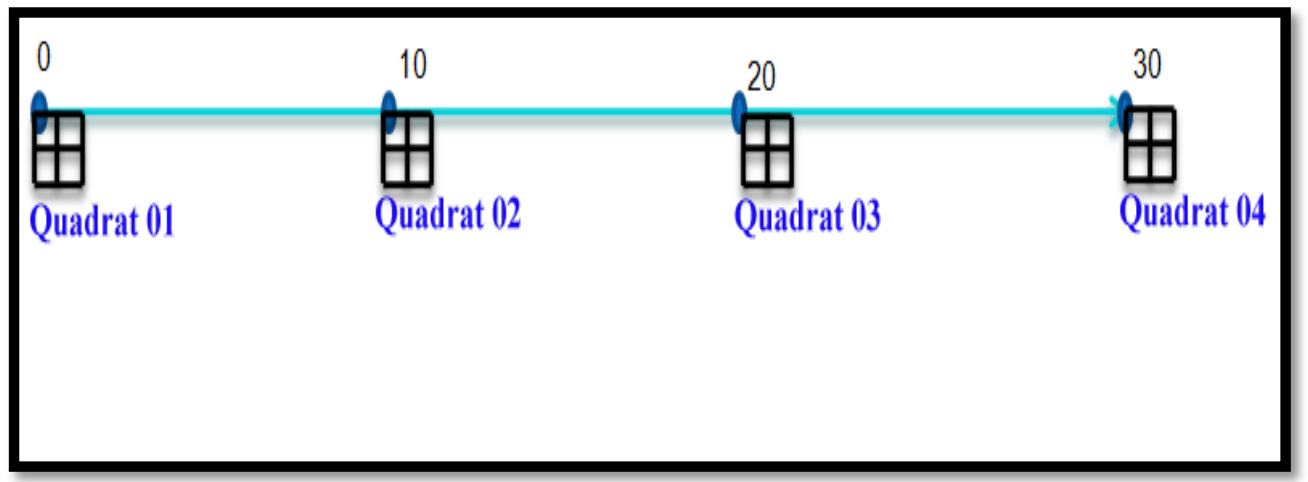

Figure 3. The Quadrats Sampling on a Transect Line

\section{b. The Qaudrat Sampling}

According to Fachrul (2007), the quadrat sampling is useful for ground animals and slowly movement of animals. Therefore we establish this method too for crab observation. The main purpose on this method is to observe how many species are presents in a small habitat one square meters. The attributes for every single quadrate as follow, length $1 \mathrm{~m}$ and 
wide $1 \mathrm{~m}$. A single station has four transects, each transects have 1 quadrat, there are 10 stations, 40 lines transect and 160 quadrates (Figure 3). Four quadrates were set up on every line transect, exactly on right side, in line with this design we will focus only on right site for observing the availability of deferent crabs species in one square meter.

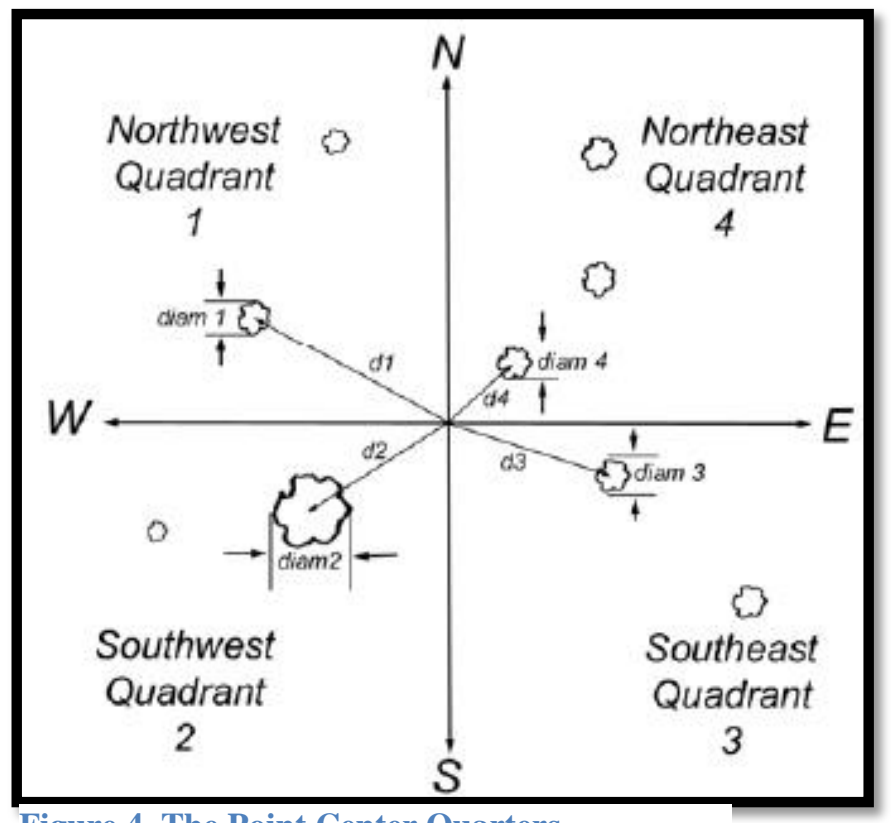

Figure 4. The Point Center Quarters

\section{Mangrove Trees Observation}

The Point Center Quarter or PCQ has used for this study in order to collect the mangrove trees data, this method also one of this sampling methods (Kleinn \& Vilcko, 2006a). The area around the sample plot is divided into four quarters (See Figure 4); quarter $1\left(0^{\circ}-90^{\circ}\right)$, quarter $2\left(90^{\circ}-180^{\circ}\right)$, quarter 3 $\left(180^{\circ}-270^{\circ}\right)$, and quarter $4\left(270^{\circ}-360^{\circ}\right)($ Figure 5), and then we looked for the nearest tree, and selected (Kleinn \& Vilcko 2006a; 2006b; Kangas \& Maltamo 2006; Kleinn 2007; Magnussen, at al., 2007).

Then we measure two variables, such as: distance from the nearest to the center point $(r=4)$ and species name. Afterward, we did species identification of mangrove trees and distance measurement on the first point, next step would be the repeated of all steps for the rest sample points along a transect line. In the case that the species name does not well indentify in the field, then would be continued with advanced identification. In order to 
support that advanced identification, we collect photographs of plant component, such as: leaf, flower, bark of stem, and root system.

\section{Substrates Measurement}

Within this measurement we counted two variables, such as: the deepness of substrates and the types of substrates. We use a conventional method by using a stick $(1.50 \mathrm{~m})$ and a tape $(5 \mathrm{~m})$ to measure substrate deepness and visual observation to distinguish types of substrates. The measurement of the deepness of substrates we stabb the stick deeply in the substrates, marking the edge on surface, and pulling a stick out, and then calculate the deepness by using tape measurement. We did measurement three times for every type of substrates along transect. For example several types of substrates are in a line transect, then we measure first type of substrate, the second type of substrate, and third type of substrate, Overall, we did the same procedure for all line transect.

These measurements are very important to describe how comfortable the substrates are for the mangrove crab communities, how many species of crab would be available in various substrates, and how well relationship between crabs diversity and substrates. We assume that crabs communities are more depend on substrates. However, in this study we are going put all components on gather as a unity of mangrove forest ecosystem, include substrates.

\section{Water Quality Measurement}

The water quality measurement as a part of this observation as well, actually this measurement is not the main variables on this observation, but the result of this measurement will provide a set of additional data to describe the study location on ecological perspective. The aim of this measurement is to get some additional information about water quality, in order to explore more about the ecological things of mangrove ecosystem in Gam Bay, because more or less the water quality was playing such important role as well, for example to provide an appropriate habitat for the crabs communities. The variables of water qualities data are collected, such as $\mathrm{pH}, \mathrm{DO}$, temperature, and salinity.

To measure the water quality we use the GLX explorer and salinometer. In the field we did the measurement on every single transect 
without replication. We took the sample on or along nor nearby the transect line, and then we did the same procedures for the whole transects. Finnally, the total sampling is 40 have been done.

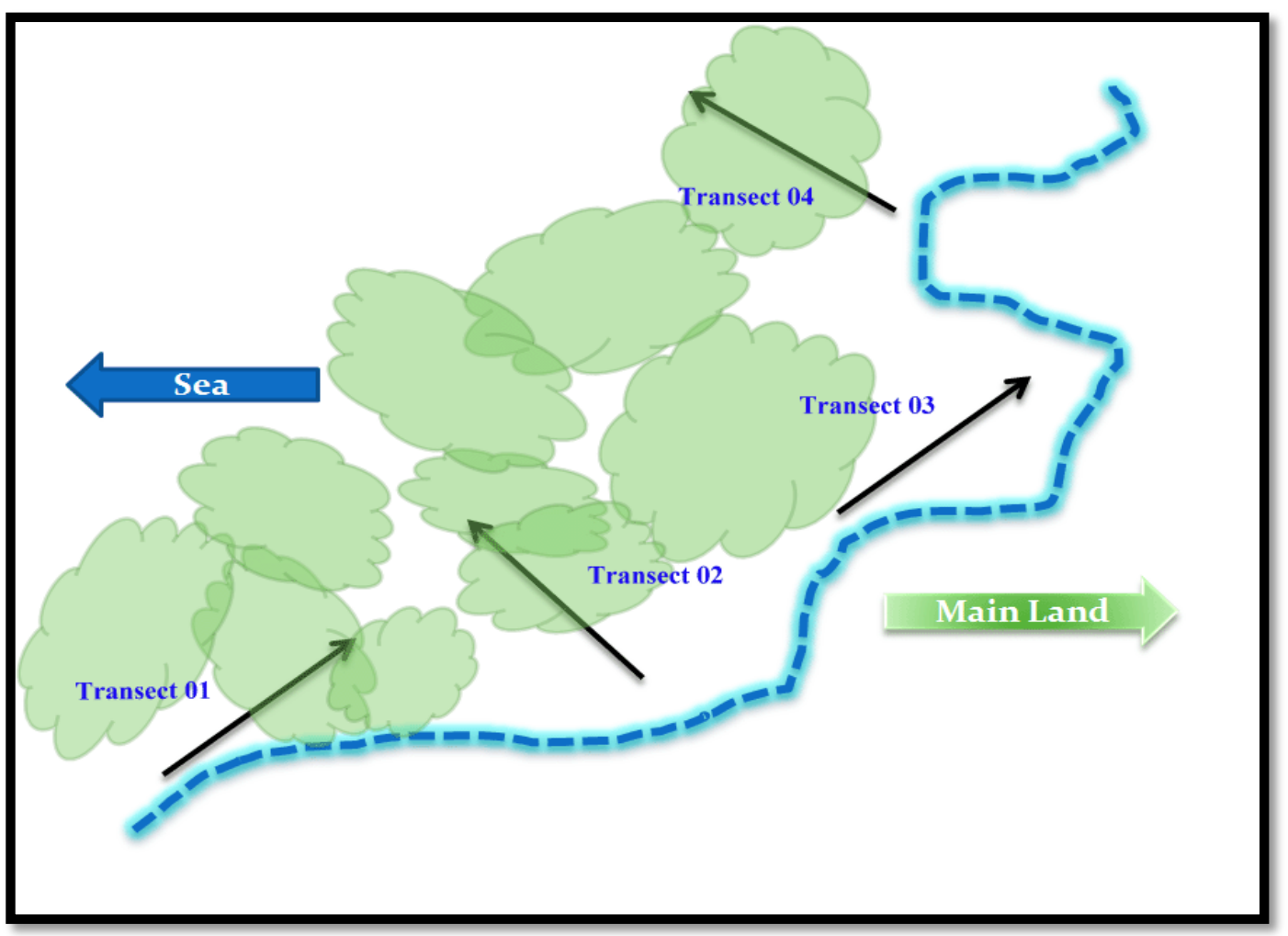

Figure 5. The Stratified Transect Design

\section{Stratified Transect Design}

In order to cover up all type of mangrove forest in a sampling site, based on the morphology of ecosystem, distribution patterns, trees species domination, zonation pattern, and the form of coastline in a particular mangrove ecosystem in Gam Bay. Then we select and set up the stratified transect. Additional reason of using this design because mangrove forest at every single station might be performed different character, like we mention before. As the consequences, we deal with the stratified design, hence the transect direction does not constant, but became adaptive directions, that way every single line transect has different directions (See Figure 5). Due to this transect design will provide good opportunity to observe all type of a mangrove forest characteristics, like we mention above. With an assumption that using this design, we are be able to count entire crab population in whole stations at Gam Bay. 


\section{Working Procedural for a Transect}

The entire observation has been done at low tide and sunny day circumstances, because too difficult for running this observation during, the hight tides, the night time and the rainy times.

We created a set of procedural called "the procedural of crab observation", this procedure is important as a field guide to increase the opportunity in doing crab observation in the field. This procedure has been done since the first day to the end of this observation. The detailed description of the procedural can be seen as follows:

a. Prepare all equipments and materials;

b. Measure the coordinate position by using GPS, exactly in the first point on every single transect;

c. Measure the transect direction by using the compass;

d. Start to do the observation in the first point along the first line at station one, for a transect we need 56.25 minutes on average to take all data. Firstly, we run the mangrove trees observation. The reason why mangrove trees observation are done firstly, because crabs species is very conscious to every single disturbances caused by observer movement, within this strategy crab will be recovered and felt secure, and they can be able to continue their foraging, fighting, and mating activities;

e. Next is observe the crabs; we counted every single individual of crab species, then measure the distance from the object or the crab to the center point. First data collection will be done at the first transect point at zero, after finishing that, then going forward to the next transect point, we was going forward until the fourth point at the first transect. The same things will be repeated at next line transect on that station;

f. Observe the substrates; this observation is done after finishing crab observation. We walk along the transect line and perform the substrate measurement. Some transect line might provide more than one type of substrate. Therefore we will mark and measure three different points for every type of substrates on a single transect;

g. Measure the water quality; this measurement is done after mangrove crab and mangrove trees observation; 
h. Measure the distances from the zero point of line transect to the highest tides point. In this measurement where a transect direction are parallel with the coastal line, then we marking three different points on the transect line, and found the mean value of them;

i. Prepare all equipments and materials for the next transect line.

\section{The Procedure of Mangrove Crabs and Mangrove Trees Identifications}

Identification procedural has been made and used to find the species name of mangrove crabs and mangrove trees name. More explanation of both indentifiaction procedurals can be seen below:

\section{The Procedure of Mangrove Crabs Identification}

This procedure is providing guidance in the field. Furthermore this procedure has facilitated our field work and identificated in advanced, such as:

a. We did crab identification for every single species base on the visual observation at points transects along the first line, by making a notes about the characteristics of that species, such as: colorist (dorsal, abdomen, walking legs, hands) and morphologies appearance (dorsal, abdomen, walking legs, hands);

b. Specified the artificial name to them, starting sp 01, sp 02, sp 03...sp n. This number or the artificial name are continues to the end of this observation;

c. Making the photograph for every single potential species. The photograph is the main variable on this observation, because we are trying to ovoid in collecting to much crab specimens;

d. Afterward, we sorted all photographs and continued to indentify crab species. We did this part in the Biology Department, Mathematics and Science Faculty, Cenderawasih University- Jayapura, Papua.

In order to make advance identification we are using two main references as the identification resources, first by using books and crustacean web sites. Those books are following:

a. Ng, P. K. L., (1998) Crabs: FAO Species Identification Guide for Fishery purposes. The Living Marine Resources of the Western Central 
Pacific. Cephalopods, Crustaceans, Holothurians and Sharks. FAO. Vol 2: 1046- 1155;

b. Ng, P. K. L., Guinot, D., \& Davie, P. J. F. (2008) Systema Brachyurorum: Part I. An Annotated Checklist of Extant Brachyuran Crabs of the World. The Raffeles Bulletin of Zoology, 17: 1-286:

c. Rahayu, D. L. \& Setyadi, G. (2009) Mangrove Estuary Crabs of the Mimika Region- Papua, Indonesia. PT Freeport Indonesia. Timika, Papua.

Not too much online information about crabs are accessible, several web addresses below are free accessed:

a. The Museum Victoria's, Crustaceans of southern Australia;

b. The Central Pacific Crustacea (Decapoda \& Stomatopoda): French Polynesia, Pitcairn, Easter Island, Clipperton;

c. Taiwanese Crab List, National Chung Hsing University.

Those web sites provide the list species and their photographs, and then we will fit the crabs photographs collection from Gam Bay with the available crabs pictures on the web site. To make sure that our crab species have the correct name, we did consultated in advance with the expert too, with Professor. Peter Ng Ken Lee, from Raffles Museum of Biodiversity Research, Department of Biological Science-The National University of Singapore, Singapore. The consultation has been done by sending the crab photographs and cross checked of the scientist name.

\section{The Procedure of Mangrove Trees Identification}

For mangrove trees identification, we used the basic data from Conservation International and Nature Conservancy, in order to figure out the field guidance of mangrove tree identification. According to McKenna, et al. (2002), the Nature Conservancy (2003), and the Conservation International Indonesia (2010), there are 25 the true mangrove species available in entire Raja Ampat Region (Appendix 2. Mangrove Diversity in Raja Ampat).

To make the mangrove tree observation keep running properly, the procedure of indentification is created, they are: 
a. Justify every single species base on the visual observation. The trees identification are not too difficult, because we will recognized the species name directly;

b. In the case that, we cannot find the species name, then continue in making a note about the characteristics of that species, of the morphologies appearance such us: flowers, leaf, trunk, and root system. Afterward we took pictures of unknown mangrove trees species.

c. Sorting the all the photographs and continue with identification, this part was done in the Biology Department, Mathematics and Science Faculty, Cenderawasih University- Jayapura, Papua.

For advanced identification of mangrove trees in Biology Department in Jayapura, we used several books, such as:

a. Noor, R. Y., Khazali, M., \& Suryadiputra, I. N. N. (1999) Paduan Pengenalan Mangrove di Indonesia, PHKA/WI-IP, Bogor. [A Field Guide of Indonesia Mangrove], Adapted from Geisen, W., Stephan, Wulffraat, Schoelten, Z. \& L. (__ A Field Guide of Indonesia Mangrove, WI-IP.

b. Geisen, W., Wulffraat, S., Zieren, M., \& Scholten, L. (2007) Mangrove Guide for Southeast Asia. FAO Regional Office for Asia and the Pacific Maliwan Mansion

\section{E. Data Analysis}

\section{Mangrove Crab Density}

The distance equation has selected to measure the density of mangrove crabs, according to Buckland et al. (1993) the half normal detection function, $g(r)=\exp \left(-r^{2} / 2 \sigma^{2}\right), 0 \leq r<\infty$ in this case we use $\sigma=2.5 \mathrm{~m}$, detection probability is $g(o)=1$, generally the detection function decrease with increasing distance. Then the surveyed area is $a=k \pi w^{2}$.

The equation for a single point is $\widehat{D}=\frac{n}{A}=\frac{n}{\pi r^{2}}$, then $k$ replicate point $\widehat{D}=\frac{n}{k \pi r^{2}}$. (Buckland, et al., 1993; 2001; 2006; Thomas, et al., 2002). The true density is estimated through $\widehat{D}=\frac{n}{\pi r^{-2}}=\frac{n \widehat{h}^{\prime}(0)}{2 \pi}$, and so for the $k$ 
replicate points is $\widehat{D}=\frac{n \cdot \widehat{h}^{\prime}(0)}{2 \pi k}$. However, this equation for the object does not occurred in clusters.

Where $D$ is density or number per unit area, $r$ is the distance from the point to each detected object, $w$ is the radius or width of area searched on each point, $n$ is the number of objects detected, $N$ population size in the study area, $k$ is the number of point transects, and $\hat{h}(0)$ is the slope of the estimated density $\hat{f}(r)$ of observed detection distance evaluated at $r=0 ; \hat{h}(0)=2 \pi / \hat{v}$, where $\hat{v}$ is the effective area of detection (Buckland, et al., 1993; 2001; 2006; Thomas, et al., 2002).

If the objects are in clusters, then the recording unit should be the cluster, not the individual object, and the analyses should be on clusters, which following this equation $\widehat{D}_{s}=\frac{n \cdot \widehat{h}(0)}{2 \pi k}$ and estimated object density is $\widehat{D}=$ $\widehat{D}_{S} \cdot \bar{S}=\frac{n \cdot \widehat{h}(0) \cdot \bar{s}}{2 \pi k}$, (Buckland, et al., 1993; 2001; 2006; Thomas, et al., 2002)

While for the cluster objects, $D_{s}$ is the product of the density of clusters, $s$ the number of individuals in each observed clusters, $\bar{s}$ is the mean of clusters size, and $E(s)$ is the average cluster size (Buckland, et al., 1993).

\section{Shannon-Wiener Index (Krebs, 1985)}

In measuring species diversity, we selected the equation of ShannonWiener Index $\left(\mathrm{H}^{1}\right)$ (Magurran, 1983; 1988; Krebs, 1985; Stiling, 1992; Barnes et al., 1997; Jorgensen et al., 2005), $H^{\prime}=-\sum p i \log 2 p i$ Where, pi is the proportion of individuals found in the species $I$, the real value of $p i$ is unknown, but it is estimated through the ratio $n i / N$, where $n i$ is the number of individuals of the species $i$ and $N$ is the total number of individuals.

Belong to the classification of the ecosystem health indicators by Jorgensen and friends (2005), there are eight levels of classification, this study is suitable with the seven levels, below:

Level 7 encompasses holistic indicators such as resistance, resilience, buffer capacity, and biodiversity, all forms of diversity, size and connectivity of the ecological network, turnover rate of carbon, nitrogen, and energy.

This study aim is to describe why the mangrove crab diversity can be use as the indicator for mangrove ecology. According to (Jorgensen, et al., 
2005) the Shannon-wiener index can take values between 0 and 5 , which mean the maximum values are considered to be indication of good condition of ecosystem, whereas low index values are considered to be indicated of pollution. To estimate the rank of crab diversity in Gam Island Bay, according to Wilha (1975) in (Fachrul, 2007)

1) $\mathrm{H}^{\prime}>3$, which mean the species diversity is high

2) $1 \leq \mathrm{H}^{\prime} \leq 3$, which mean the species diversity is moderate

3) $\mathrm{H}^{\prime}<1$, which mean the species diversity is poor

\section{Simpson Index}

The Simpson index (1949) is referred to as measurement that mostly ponders the abundance of common species instead of the enrichment of the species (Krebs, 1985; Magurran, 1988; Stiling, 1992; Jorgensen et al., 2005), $D=\sum P_{i}^{2}$, where $p_{i}$ is the individual proportion of the species $i$. This index for a finite community we use $1-D=\sum\left[n_{i}\left(n_{i}-1\right) / N(N-1)\right]$ where $n_{i}$ is the number of individuals in the species $i$ and $N$ is the total number of individuals (Brewer, 1994; Barnes et al., 1997; Magurran, 1983). The value Simpson index is usually from 0 to 1 , we can put the rank whitin this value below:

1) $0,67 \leq \mathrm{H}^{\prime} \leq 0,99$, is mean the species diversity is high

2) $0,34 \leq H^{\prime} \leq 0,66$, is mean the species diversity is moderate

3) $0 \leq \mathrm{H}^{\prime} \leq 0,33$, is mean the species diversity is poor

\section{Margalef Index}

The Margalef index quantifies the diversity related to specific richness of the total number of individual (Magurran, 1983; 1988, Krebs, 1985; Stiling, 1992; Jorgensen et al., 2005). Margalef Index by Clifford \& Stephenson, 1975 , is $D=\frac{S-1}{L n N}$ (Magurran, 1988; Jorgensen et al., 2005), where, $S$ is the number of species and $N$ is the total number of individuals. High values are usually associated to healthy systems (Jorgensen, 2005), while the highest value of margalef index is parallel with the richness status, therefor we can give the rank values below:

1) $<2.05$ poor status of environment and richness

2) $2.06-4$ is moderate status of environment and richness 
3) $>4$, good status of environment and richness

\section{Point Center Quarter Analysis}

This method allowed measuring the same main variables, such as: the distance from the sample point to the closest individual in each quadrate and the species. However to measure trees density, we are use this equation $\widehat{D}=\frac{1}{\bar{d}^{2}}$ whereas

$\bar{d}=\sum_{i=1}^{n} d_{i} / n$ (Gray,___ Elzinga, 1998) Where, $\widehat{D}$ is density for a single point, $n$ is the total number of individuals, and $\bar{d}$ is the average value of distance for a single point.

\section{Substrates Measurement analysis}

According to the description of substrates measurement (see the Chapter II.C.4) we observed the types and collected the sample of substrates by using visual observation and by stabbing a stick down on substrates. The measurement of substrate deepness, we did stabbing three times for every type of substrates along a transect line. Then we calculated the mean value. Whole data substrates will analyze by using qualitative method, by the explaination of the distribution of substrates as crab habitat and we tryied to describe more about how the substrates can contribute the crab communities.

\section{Simple Linear Regression}

Two variables of mangrove community and crabs community are used in this study, all variables lead to the main objective is to investigate whether there are relationship among mangrove crabs communities and mangrove ecosystem. The questions for this scenario are:

1) Whether those variables are related?

2) How strong the relationships appear to be?

Therefore the regression analysis has been used to answer those questions. Two regression models are appropriate for this scenario, this equation was counted two variables $Y$ and $X$, where the equation for the simple linear regression model is $Y_{i}=\beta_{0}+\beta_{1} x_{i}+e_{i} \ldots i=1, \ldots, n$ (Johnson \& Bhattacharyya, 1996). This model may change to be a simple equation base on the least square method, following $Y_{i}=a+b X_{i}$ (Mangel, 2006; McCarthy, 2007), where $Y_{i}=$ denotes the response corresponding to the $i$ th experimental 
run in which the input variable $\mathrm{x}$ is set at the value $\mathrm{x}_{\mathrm{i}}$, Where $y_{i}$ is dependent variable, $x_{i}$ is independent variables (Johnson \& Bhattacharyya, 1996; Mangel, 2006; Sugiarto, 2006, and McCarthy, 2007).

In order to measure the significantly of lenear regression (between the $x$ and $y$ ), we are use the coefissien correlation $\left(\mathrm{R}^{2}\right)$ or the Pearson's Index (Johnson \& Bhattacharyya, 1996; McCarthy, 2007). The coeffesien correlation denotes by $\mathrm{R}$. The value of $\mathrm{R}$ is between -1 and +1 . Where

1) $r>0$, if the pattern of $(x, y)$ value is a band that runs from lower left to upper right

2) $\mathrm{r}<0$, if the pattern of $(\mathrm{x}, \mathrm{y})$ value is a band that runs from upper left to lower right

3) $r=+1$, if all $(x, y)$ value lie exactly on a strainght line with a positive slope (perfect positive linear relation)

4) $r=-1$, if all $(x, y)$ value lie exactly on a strainght line with a negative slope (perfect negative linear relation)

\section{The Ranks of Disturbances at 10 Stations}

To estimate the level of disturbances at ten stations, we were created the level of disturbances base to the rank variables, with given following value 1, 2, 3, 4, and 5. Moreover, the ranking parameters are illustrated below:

a. The Ranks of Distances from the Human Population to Station

Which mean if the distance in between a mangrove forest and a village are very close, it mean that area have highest disturbances. Then if the distance is far away from a village, it mean that area have lowest disturbances. All rank for this variable are described below (Table 1):

Table 1. The Rank of Distances from the human population to Station
\begin{tabular}{|l|l|}
\hline Ranking & Notation \\
\hline 1 & Very close to the village, approximately about $0-500 \mathrm{~m}$ \\
\hline 2 & Close to the village, approximately about $500-1000 \mathrm{~m}$ \\
\hline 3 & Moderate, approximately about $1000-2500 \mathrm{~m}$ \\
\hline 4 & Far, approximately about $2500-5000 \mathrm{~m}$ \\
\hline 5 & Very remote, approximately about $>5000 \mathrm{~m}$ \\
\hline
\end{tabular}

b. The Ranks of Rubbish Availability in a Stations

The connotation of rubbish availability is attendances of non natural materials in mangroves ecosystem, such as: plastics, fabrics, cloths, et 
cetera. If there are many rubbish covered along the coastline on a mangrove ecosystem, it mean the rubbish availability is highest (see Table 02).

Table 2. The Ranks of Rubbish Availability in a Station

\begin{tabular}{|c|l|}
\hline Ranking & Notation \\
\hline 1 & $\begin{array}{l}\text { There were many rubbish are covered along the coastline in a } \\
\text { station }\end{array}$ \\
\hline 2 & $\begin{array}{l}\text { There were not too many rubbish are covered along the coastline a } \\
\text { station }\end{array}$ \\
\hline 3 & $\begin{array}{l}\text { Moderate, were several clusters of rubbish are laying on the } \\
\text { coastline a station }\end{array}$ \\
\hline 4 & $\begin{array}{l}\text { There are very few rubbish are available along the coastline in a } \\
\text { station }\end{array}$ \\
\hline 5 & There were no rubbish at all \\
\hline
\end{tabular}

c. The Ranks of Cutting Trees Activities for the Constructions Material Porpuse

The connotation is availability of cutting mangrove tree activities by the local peoples for the construction materials puporse. To investigate those things, we used the visual observation by observe: cutting stems and unnatural gap. All rank for this variable is described below (Table 3):

Table 3. The Ranks of Cutting Trees Activíties for the Constructions Material Porpuse

\begin{tabular}{|c|l|}
\hline Ranking & Notation \\
\hline 1 & $\begin{array}{l}\text { There were many cutting stems and several unnatural gaps in a } \\
\text { station }\end{array}$ \\
\hline 2 & $\begin{array}{l}\text { There were not too many cutting stems and one or two unnatural } \\
\text { gaps in a station }\end{array}$ \\
\hline 3 & $\begin{array}{l}\text { Moderate, there were few cutting stems and an unnatural gap in a } \\
\text { station }\end{array}$ \\
\hline 4 & There were several cutting stems \\
\hline 5 & There were no cutting stems and no unnatural gap in a station \\
\hline
\end{tabular}

\section{d. The Rank of Gardening Activity in the Landscape}

Table 4. The Rank of Gardening Activity

\begin{tabular}{|c|l|}
\hline Ranking & Explanations \\
\hline 1 & There were a garden or two big gardens are nearby a station \\
\hline 2 & There were a garden or a big gardens are nearby a station \\
\hline 3 & Moderate, there were a small garden is nearby a station \\
\hline 4 & There were a former garden is nearby a station \\
\hline 5 & There were no a garden activities \\
\hline
\end{tabular}


That connotation of this variable is the availability of traditional garden nearby a station. To investigate those things, we used the visual observation by observing the availability of traditional garden and estimate how big the garden is. All rank for this variable are describe on table 4 above.

\section{e. The Ranks of Transportation Activities}

The connotation of the transportation activities is mangrove ecosystem is being used as a transportation route by local people. These transportation activites are often created disturbances, example noises and demages. To investigate those things, we are used the visual observation and recorded with the local people. The ranks for this variable are described in table 5 above.

Table 5. The Rank of Transportation Activities

\begin{tabular}{|c|l|}
\hline Ranking & Explanations \\
\hline 1 & Very busy for the transportation activities \\
\hline 2 & Busy for the transportation activities \\
\hline 3 & Moderate \\
\hline 4 & Not too busy for the transportation activities \\
\hline 5 & There is no transportation activities \\
\hline
\end{tabular}

\section{f. The Ranks of Logging activities}

Table 6. The Rank of Logging Activities

\begin{tabular}{|c|l|}
\hline Ranking & Notation \\
\hline 1 & $\begin{array}{l}\text { There were logging activities and several unnatural gaps in a station, } \\
\text { and still on going }\end{array}$ \\
\hline 2 & $\begin{array}{l}\text { There were few cutting stems as a logging activity and a small } \\
\text { unnatural gaps in a station }\end{array}$ \\
\hline 3 & Moderate, \\
\hline 4 & There were less than few cutting stems as a logging activity \\
\hline 5 & There were no logging activity in a station \\
\hline
\end{tabular}

The connotation is availability of logging activities by the locals. To investigate those things, we used the visual observation by observing: cutting stems and unnatural gap. The rangk of logging has dicribes above (see Table 6).

The final calculations for the rank of disturbances of the ten stations, we will calculate the mean value of each variable, then put them in the ranking list, it was described below (Table 7). 
Table 7. The Ranks of Station Disturbances

\begin{tabular}{|l|l|}
\hline Value & Status \\
\hline$\leq 1$ & Highest disturbances \\
\hline$>1 \leq 2$ & High disturbances \\
\hline$>2 \leq 3$ & Moderate \\
\hline$>3 \leq 4$ & Low \\
\hline$>4 \leq 5$ & No disturbances \\
\hline
\end{tabular}

\section{F. The Limitations}

The limitation has been occurring during this observation in Gam Bay, several limitations were described below:

\section{The High and Low Tide of Sea Water}

The observation was done at the day low tides circumstances. Periodically, in every month, it has two times of the day low tides and once the night low tide. The day lowtide happen is around $7-8$ days, and 7- 8 days the night low tides. The problems are: we can not run the observation at the night lowtides; somehow the day lowtide is very short is around $2-2.5$ hours before going down. Those situations were created neither delaying nor waiting the observation.

\section{The Rainy Day}

During a day if the rain is coming it will cause the observation will delayed for a couple hours, because mangrove crab does not active in the rainy times. Crab will escape and wait on their hole until the rain was gone. The result of this circumstance can cancel the observation for a couple hours, yet after the rain stop, and then we have to wait about an hour until the ground became dry. This situation can delayed or canceled the observation for a day or couples hours, this also contribute to the expansion the observation time.

\section{Crabs Behavioral}

The crabs species are very sensitive and aware for every single disturbances which is done by observer movement, some crabs species will immediately flee before be detected. This circumstance was contributed declining detection probability. 


\section{The Point Transect}

The point transect method is never used for the crabs observation, it mean there were no guidelines at all, than it would crate problems in the field. For example, the borrows of crabs are very close to the standing position of observer, cause crabs will choose to stay in their borrows and we can not count that individual. Therefore understanding the method and the behavioral of crabs is important, in order to minimize the problems and to improve the detection probability.

\section{No Data about Crab Diversity in Raja Ampat}

There is no data base about of crab diversity in Raja Ampat, as the consequence we have to indentify the crab in the field without the field guideline of crab indentification, at least to recognize differentiation among crab species and give an artificial name. That situation will take many times for dicribe the crab. As consequences; we have to spend two days in a station. 


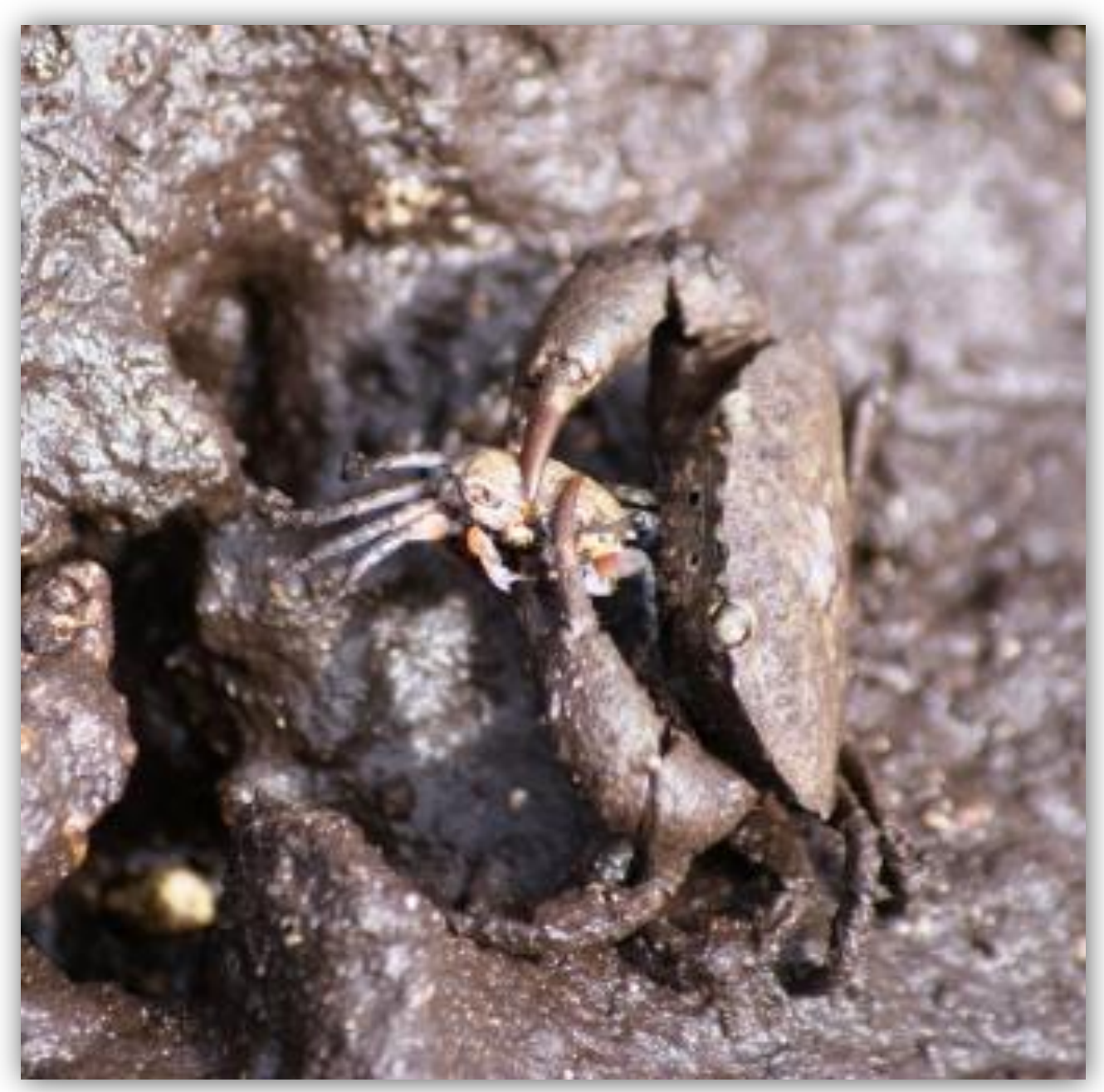

Epixanthus dentatus eating Uca sp 15 


\section{Chapter IV Results}

\section{A. Gam Bay}

\section{Physical Environment of Gam Bay}

Gam region is consists of one main island called Gam Island and also many small neither smallest islands. Generally, the physical environment and oceanographic features in Raja Ampat as a region and Gam as a part of Raja Ampat region are comparable. McKenna and friends (2002) describe the physical environmental characteristic of Raja Ampat, as follow, typically this islands is influences by monsoon regime of winds and rainfall. The dry season is generally from October to March, while highest rainfall occurred April and September. The wettest season is generally June and July. Whereas, the southeast wind season is between May and October, from the northwest between December and March.

Maximum daily tide fluctuation is approximately $1.8 \mathrm{~m}$, with an average daily fluctuation of about 0.9-1.3m (McKenna, 2002). Periodic strong current is common through the Raja Ampat region, especially in channels between islands (McKenna, 2002), the same situations also occur in Gam Island. However, inside the bay not have too strong current, but if the southern wins come that place is being shelter. Sea temperature is $27-28^{\circ} \mathrm{C}$, base on the water qualities measurement within this observation from ten different stations and 40 transect in Gam bay, the mean value of them follows, salinity: 31.7, DO: 6.8, pH: 7.9, and temperature: $29.3{ }^{\circ} \mathrm{C}$.

\section{10 Stations in Gam Bay}

We established ten locations as the research stations; it is started from the eastern to western coastline of Gam Island. All stations are following the clusters and wide of mangrove ecosystem, and then we divided the Gam bay area into four clusters, such as: the east coastline cluster, islands, the coves, and inlet bay (See Figure 6). Base on that circumstance, therefore the distances from a station to another station are not constant (See Figure 5).

Three stations in the east coastline of Gam Island such as: St.War Iprim, St. Kapisawar, and St. War Beren, where those stations are not connected one another. Two stations in outlet of Gam Bay or as islands clusters, such as: St. 
Bun Iba Island, and St. Bun Mkun. Whiles, three stations in coves the west coastline of Gam Island, only these stations are connected one to another, such as: St. Tapor Pandera, St. Kim Far, and St. Warbeki. We also establish two stations inlet or down to the bottom of Gam bay, such as: St. War Ongkor and St. War Manak (See Figure 6 and Table 8)

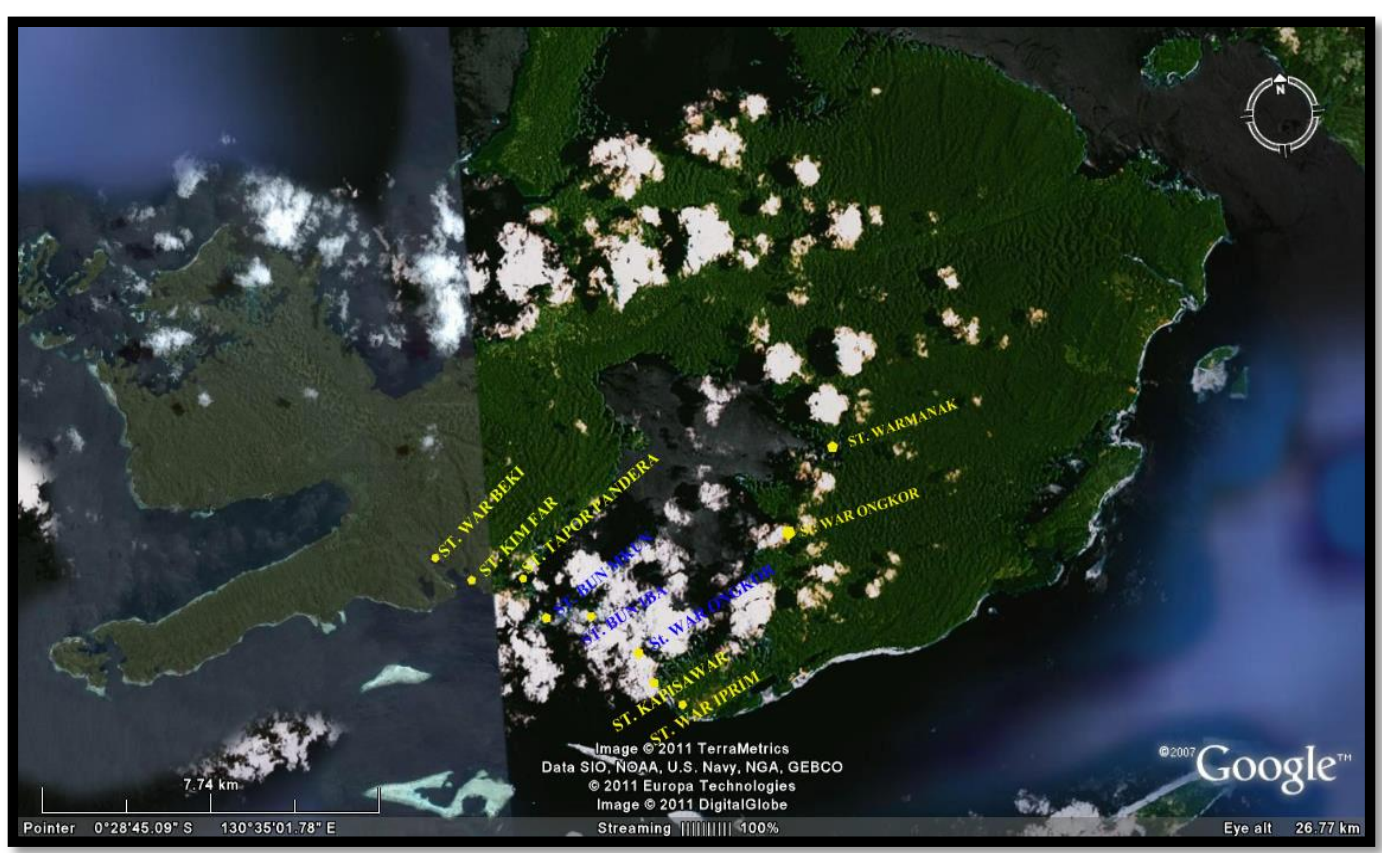

Figure 6. Ten Sampling Station at Gam Bay

Table 8. The Coordinates Position of Ten Stations in Gam Bay

\begin{tabular}{|c|c|c|c|c|}
\hline Stations & Transect 01 & Transect 02 & Transect 03 & Transect 04 \\
\hline St. War Iprim & $\begin{array}{l}\mathrm{S} 00^{\circ} 32^{\prime} 00.7^{\prime \prime} \\
\mathrm{E} 130^{\circ} 35^{\prime} 08.4^{\prime \prime}\end{array}$ & $\begin{array}{l}\mathrm{S} 00^{\circ} 32^{\prime} 01.8^{\prime \prime} \\
\mathrm{E} 130^{\circ} 35^{\prime} 06.7^{\prime \prime}\end{array}$ & $\begin{array}{l}\mathrm{S} 00^{\circ} 32^{\prime} 02.4^{\prime \prime} \\
\mathrm{E} 130^{\circ} 35^{\prime} 05.0^{\prime}\end{array}$ & $\begin{array}{l}\mathrm{S} 00^{\circ} 32^{\prime} 04.1^{\prime \prime} \\
\mathrm{E} 130^{\circ} 35^{\prime} 02.8^{\prime \prime}\end{array}$ \\
\hline St. Kapisawar & $\begin{array}{l}\text { S } 00^{\circ} 31^{\prime} 54.1^{\prime \prime} \\
\text { E } 130^{\circ} 34^{\prime} 31.5^{\prime \prime}\end{array}$ & $\begin{array}{l}\text { S } 00^{\circ} 31^{\prime} 58.4^{\prime \prime} \\
\text { E } 130^{\circ} 34^{\prime} 31.6^{\prime \prime}\end{array}$ & $\begin{array}{l}\mathrm{S} 00^{\circ} 31^{\prime} 58.6^{\prime \prime} \\
\text { E } 130^{\circ} 34^{\prime} 35.9^{\prime \prime}\end{array}$ & $\begin{array}{l}\mathrm{S} 00^{\circ} 32^{\prime} 51.5^{\prime \prime} \\
\mathrm{E} 130^{\circ} 34^{\prime} 36.5^{\prime \prime}\end{array}$ \\
\hline St. War Beren & $\begin{array}{l}\mathrm{S} 00^{\circ} 30^{\prime} 27.4^{\prime \prime} \\
\mathrm{E} 130^{\circ} 34^{\prime} 15.7^{\prime \prime}\end{array}$ & $\begin{array}{l}\mathrm{S} 00^{\circ} 31^{\prime} 26.3^{\prime \prime} \\
\mathrm{E} 130^{\circ} 34^{\prime} 14.2^{\prime \prime}\end{array}$ & $\begin{array}{l}\mathrm{S} 00^{\circ} 31^{\prime} \quad 24.9^{\prime \prime} \\
\mathrm{E} 130^{\circ} 34^{\prime} 12.2^{\prime \prime}\end{array}$ & $\begin{array}{l}\mathrm{S} 00^{\circ} 31^{\prime} 21.6^{\prime \prime} \\
\mathrm{E} 130^{\circ} 34^{\prime} 11.3^{\prime \prime}\end{array}$ \\
\hline $\begin{array}{l}\text { St. Bun Iba } \\
\text { Island }\end{array}$ & $\begin{array}{l}\text { S 00³0' } 41.4^{\prime \prime} \\
\text { E } 130^{\circ} 33^{\prime} 24.6^{\prime \prime}\end{array}$ & $\begin{array}{l}\mathrm{S} 00^{\circ} 30^{\prime} 42.9^{\prime \prime} \\
\mathrm{E} 130^{\circ} 33^{\prime} 24.8^{\prime \prime}\end{array}$ & $\begin{array}{l}\mathrm{S} 00^{\circ} 30^{\prime} \quad 42.0^{\prime \prime} \\
\mathrm{E} 130^{\circ} 33^{\prime} 25.6^{\prime \prime}\end{array}$ & $\begin{array}{l}\mathrm{S} 00^{\circ} 30^{\prime} 41.9^{\prime \prime} \\
\mathrm{E} 130^{\circ} 33^{\prime} 26.2^{\prime \prime}\end{array}$ \\
\hline $\begin{array}{l}\text { St. Bun Mkun } \\
\text { Island }\end{array}$ & $\begin{array}{l}\mathrm{S} 00^{\circ} 30^{\prime} 48.5^{\prime \prime} \\
\mathrm{E} 130^{\circ} 32^{\prime} 57.0^{\prime \prime}\end{array}$ & $\begin{array}{l}\mathrm{S} 00^{\circ} 30^{\prime} 45.8^{\prime \prime} \\
\mathrm{E} 130^{\circ} 32^{\prime} 56.7^{\prime \prime}\end{array}$ & $\begin{array}{l}\mathrm{S} 00^{\circ} 30^{\prime} 49.9^{\prime \prime} \\
\mathrm{E} 130^{\circ} 32^{\prime} 55.5^{\prime \prime}\end{array}$ & $\begin{array}{l}\mathrm{S} 00^{\circ} 30^{\prime} 50.5^{\prime \prime} \\
\mathrm{E} 130^{\circ} 32^{\prime} 54.8^{\prime \prime}\end{array}$ \\
\hline $\begin{array}{l}\text { St. Tapor } \\
\text { Pandera }\end{array}$ & $\begin{array}{l}\mathrm{S} 00^{\circ} 30^{\prime} 37.3^{\prime \prime} \\
\mathrm{E} 130^{\circ} 32^{\prime} 42,8^{\prime \prime}\end{array}$ & $\begin{array}{l}\mathrm{S} 00^{\circ} 30^{\prime} 36.5^{\prime \prime} \\
\mathrm{E} 130^{\circ} 32^{\prime} 40,7^{\prime \prime}\end{array}$ & $\begin{array}{l}\mathrm{S} 00^{\circ} 30^{\prime} 35.2^{\prime \prime} \\
\mathrm{E} 130^{\circ} 32^{\prime} 39,9^{\prime \prime}\end{array}$ & $\begin{array}{l}\mathrm{S} 00^{\circ} 30^{\prime} 32.6^{\prime \prime} \\
\mathrm{E} 130^{\circ} 32^{\prime} 37,9^{\prime \prime}\end{array}$ \\
\hline St. Kim Far & $\begin{array}{l}\text { S 00³0' } 35.8^{\prime \prime} \\
\text { E } 130^{\circ} 32^{\prime} 29.8^{\prime \prime}\end{array}$ & $\begin{array}{l}\text { S } 00^{\circ} 30^{\prime} 33.6^{\prime \prime} \\
\text { E } 130^{\circ} 32^{\prime} 29.4^{\prime \prime}\end{array}$ & $\begin{array}{l}\mathrm{S} 00^{\circ} 30^{\prime} 32.9^{\prime \prime} \\
\mathrm{E} 130^{\circ} 32^{\prime} 28.3^{\prime \prime}\end{array}$ & $\begin{array}{l}\mathrm{S} 00^{\circ} 30^{\prime} 29.9^{\prime \prime} \\
\mathrm{E} 130^{\circ} 32^{\prime} 26.4^{\prime \prime}\end{array}$ \\
\hline St. War Beki & $\begin{array}{l}\text { S } 00^{\circ} 29^{\prime} 56.5^{\prime \prime} \\
\text { E } 130^{\circ} 31^{\prime} 47.3^{\prime \prime}\end{array}$ & $\begin{array}{l}\text { S } 00^{\circ} 30^{\prime} 29.9^{\prime \prime} \\
\text { E } 130^{\circ} 32^{\prime} 26,4^{\prime \prime}\end{array}$ & $\begin{array}{l}\mathrm{S} 00^{\circ} 30^{\prime} 58^{\prime \prime} \\
\mathrm{E} 130^{\circ} 31^{\prime} 49^{\prime \prime}\end{array}$ & $\begin{array}{l}\mathrm{S} 00^{\circ} 29^{\prime} 00.5^{\prime \prime} \\
\mathrm{E} 130^{\circ} 31^{\prime} 47,3^{\prime \prime}\end{array}$ \\
\hline St. War Manak & $\begin{array}{l}\mathrm{S} 00^{\circ} 30^{\prime} 04.0^{\prime \prime} \\
\mathrm{E} 130^{\circ} 36^{\prime} 12.6^{\prime \prime}\end{array}$ & $\begin{array}{l}\text { S } 00^{\circ} 27^{\prime} 54.9^{\prime \prime} \\
\text { E } 130^{\circ} 35^{\prime} 48.6^{\prime \prime}\end{array}$ & $\begin{array}{l}\text { S } 00^{\circ} 27^{\prime} 53.6^{\prime \prime} \\
\text { E } 130^{\circ} 35^{\prime} 49.9^{\prime \prime}\end{array}$ & $\begin{array}{l}\mathrm{S} 00^{\circ} 27^{\prime} 53.8^{\prime \prime} \\
\text { E } 130^{\circ} 35^{\prime} 52.6^{\prime \prime}\end{array}$ \\
\hline St. War Ongkor & $\begin{array}{l}\text { S 00² } 29^{\prime} 58.1^{\prime \prime} \\
\text { E } 130^{\circ} 36^{\prime} 08.6^{\prime \prime}\end{array}$ & $\begin{array}{l}\mathrm{S} 00^{\circ} 20^{\prime} 00.4^{\prime \prime} \\
\mathrm{E} 130^{\circ} 36^{\prime} 09.1^{\prime \prime}\end{array}$ & $\begin{array}{l}\mathrm{S} 00^{\circ} 30^{\prime} 01.9^{\prime \prime} \\
\mathrm{E} 130^{\circ} 36^{\prime} 10.4^{\prime \prime}\end{array}$ & $\begin{array}{l}\mathrm{S} 00^{\circ} 30^{\prime} 03.6^{\prime \prime} \\
\mathrm{E} 130^{\circ} 36^{\prime} 12.1^{\prime \prime}\end{array}$ \\
\hline
\end{tabular}


However, the mangroves ecosystem does not cover all coastline and islands in Gam Bay area, while some mangroves ecosystem are not big enough to establish a station, at least a station area have to provide four transect lines. Therefore, we adapted the clusters of stations base on the characteristics of mangrove ecosystem in Gam Bay. Two stations in the clusters of inlet area, it might be not represented the entire inlet area of Gam Bay, because the characteristics of mangrove ecosystem over there are consist of small clusters in the northern, then in the western there are no mangrove forest, while mangrove more concentrated in western inlet area of Gam Bay.

\section{The Level of Disturbances in Ten Stations of Gam Bay}

The six variables have used in order to estimate the level of disturbances, each variables are linkage, however the most influences variable is the distances from the station to a village, because it being easy for human intervention. The level of disturbances show that disturbances probability is higher in a mangrove forest area, where a mangrove forest area is close to a village, for example: St. Kapisawar, St. War Iprim, and St. War Beren (appear in Table 9). The probability of disturbances is decrease, if the distances are increase as well, these circumstances take place in St. Kim Far, St.War Beki, St. War Ongkor and St. War Manak (appear in Table 9).

Table 9. The Level of Disturbances in Ten Stations in Gam Bay

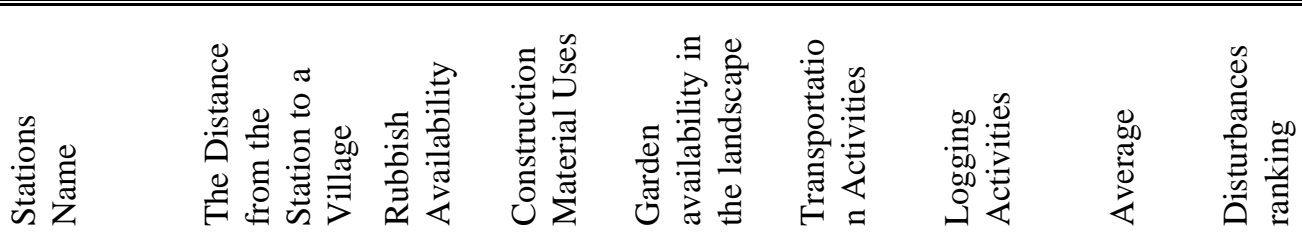

$\begin{array}{lcccccccc}\text { St. Kapisawar } & 1 & 2 & 2 & 2 & 1 & 3 & 1.8 & \text { High } \\ \text { St. War Ipirm } & 2 & 4 & 4 & 3 & 2 & 4 & 3.2 & \text { Low } \\ \text { St. War Beren } & 3 & 4 & 4 & 2 & 2 & 5 & 3.3 & \text { Low } \\ \text { St. Bun Iba } & 3 & 3 & 5 & 4 & 3 & 5 & 3.8 & \text { Low } \\ \text { St. Bun Mkun } & 3 & 4 & 4 & 3 & 3 & 5 & 3.7 & \text { Low } \\ \text { St. Tapor Pandera } & 4 & 5 & 3 & 4 & 3 & 5 & 4.0 & \text { Low } \\ \text { St. Kim Far } & 5 & 5 & 5 & 5 & 3 & 5 & 4.7 & \text { No } \\ \text { St. War Beki } & 5 & 5 & 4 & 4 & 3 & 4 & 4.2 & \text { No } \\ \text { St. War Ongkor } & 5 & 5 & 4 & 5 & 4 & 5 & 4.7 & \text { No } \\ \text { St. War Manak } & 5 & 5 & 4 & 5 & 4 & 5 & 4.7 & \text { No } \\ \text { Average } & 3.6 & 4.2 & 3.9 & 3.7 & 3.7 & 4.6 & 4.0 & \text { Low }\end{array}$

Where the mean value is the average of all rank from the whole variables, $\leq 1$ is highest disturbances, $>1 \leq$ 2 high disturbances, $>2 \leq 3$ is moderate, and $>4 \leq 5$ is no disturbances 
Others variable happen because of consequences the first variable as the major cause to the level of disturbances in a mangrove forest area. Where surrounding Gam Island there were five villages, it was including an Island village called Arborek. Commonly, those mangrove forests with high level of disturbances are the open area for explorations and easily to access. That mangrove area is open for exploration and harvesting because they are not a "Sasi Area" or "Pamali Area" or called traditionally protected area. However, the average value of all variable has showing that the entire Gam Bay Area have low level of disturbances (Appear in Table 9).

\section{B. Mangrove Ecosystem and Crabs Habitat in Gam Bay, Raja Ampat Islands}

\section{Mangrove Ecosystem in Gam Bay, Raja Ampat Islands}

The total areas are occupied by mangrove forest in Raja Ampat are about 27,180 ha (Table 10), however not all islands area has mangrove forest. The largest mangrove area was occurred in Waigeo Island (North Kabuy Bay, Mayalibit Bay, Southwest, Alyui Bay, and Saripa Bay) and Misool Island (McKenna, et al., 2003; Ainsworth, et. al., 2008; CII, 2011). Islands which are settled, Yeben Kecil Island, Batang Pele, Tamagui, Wruwares, Gam, Equator, and Fam Island (McKenna, et al., 2003). There is no data about how large is mangrove forest area in Gam Island. However, mangrove forests in Gam Bay are more concentrated in two major locations, Gam Bay and Besir Bay (McKenna, et al., 2002), while other mangrove forest were situated in Putus Peninsula, Nyandebabo Island, and Kabui.

Various characteristics and distribution pattern of mangrove ecosystem are occurred in Gam Bay, due to three main factors, as follow morphology pattern and physical environment of the Gam Island. Then as the result mangrove forests are constrated in several places in Gam Bay Island, such as: small Islands, small bays or coves, rivers system, and coastlines. Therefore, the stations are adapted toward distribution and characteristics of mangrove ecosystem (Figure 6). 
Table 10. The Areas Occupied by Mangrove Forest in Raja Ampat

\begin{tabular}{|l|l|l|}
\hline State & Mangrove Area $\left(\mathrm{ha}^{2}\right)$ & Sources \\
\hline Salawati Island & 4,258 & CII, 2011 \\
\hline Batanta Island & 785 & CII, 2011 \\
\hline Kafiau Island & 2,391 & McKenna, et al., 2002 \\
\hline Misool Island & 8,093 & CII, 2011 \\
\hline Waigeo Island & 6,843 & McKenna, et al., 2002, CII, 2011 \\
\hline Raja Ampat Islands & 27,180 & CII, 2011 \\
\hline
\end{tabular}

The cluster distributions of the ten stations are described below, such as:

a. The Mangrove ecosystem in Small Islands.

1) Station Bun Iba Island

This island is formed by rocky formation with small pieces of coastal vegetation and mangroves. Then surrounding this island was covering by flat rocky, and in above of the existing substrate. There are two ecosystem are connected with island such as sea grass and coral reef ecosystems. The varoius substrates are formed by muddy, sandy-mud, sandy, and flat rocky. While, the average of substrate deepness are $36.5 \mathrm{~cm}$, however in another place in this island is covered by sand. The distances from the point of lowest tides to the nearest $7.2 \mathrm{~m}$. Mean value of water variable, following as: salinity 33.3\%o, DO 5.2, $\mathrm{pH} 7.9$, and temperature $29.0 \mathrm{C}^{0}$. Four true mangrove species are dominant in this island, they are: Bruguieria gymnorrhiza, Sonneratia alba, and Rizophora stylosa.

\section{2) Station Bun Mkun}

This island looks similar to Bun Iba island, this island is the rocky island as well, connected with both ecosystem coral reed and sea grass. The clusters distributions of mangroves are found in western, eastern, and northern of Mkun. Three species are dominant in this island, such as: Rizophora mucronata, Aegicera. corniculatum, and $B$. gymnorrhiza. Coastal vegetation consists of coconut tree, shrub, and etc. The distances from the point of lowest tides to the nearest transect is about $6 \mathrm{~m}$. Substrates are formined by sandy and muddy, sandier are dominant in lowest tides and vertically became a mixer muddy and sand. The mean of substrate deepness is $36.7 \mathrm{~cm}$, and for the water variable are: salinity $32.8 \%$, DO $8.3, \mathrm{pH} 8.1$, and temperature $29.3 \mathrm{C}^{0}$. 


\section{b. Mangrove Ecosystem Occupied the Coves.}

There are many small coves surrounding the coast line of Gam Bay, however not all of them have mangrove forest, only several coves have mangrove ecosytsem, such as: Dore Bekti, Kimdores, Kimfar, Tapor Pandera, War Beki, and Jawadore. In this time we are choosing Tapor Pandera, Kim Far, and War Beki as the sampling areas, because these stations have large mangrove area, second they are represented the cove cluster of mangrove ecosystems.

1) Station Tapor Pandera

The station Tapor Pandeta is connected to Kim Far and War Beki, there were coastal vegetation and several association species are present in this station, such as Callophylum spp. and Insia Spp. While mangroves forest is situated along coastline of Tapor Pandera, starting from the eastern Tapor Pandera cove down to Kim Far and continues to Warbeki Cove. Then true mangrove species are dominant in this area, such as: Burguiera sexangula and Ceriops decandra, beside those species, there were B. gymnorrhiza, C. tagal, Sonneratia alba, and $R$. stylosa. Substrates as the habitat for mangrove and crabs are forming by sandy and muddy, in couple place is dominated by more sand and other is dominated by more mud. The distance in between lowest tides and the nearest is $6.2 \mathrm{~m}$. The mean deepness of substrate is $43.7 \mathrm{~cm}$. Mean value of water variable, following as: salinity $32.8 \%$, DO 8.3, $\mathrm{pH} 8.1$, and temperature $29.3 \mathrm{C}^{0}$.

\section{2) Station Kim Far}

The situation in station Kim Far is parallel with St. Tapor Pandera and War Beki River. The mangroves ecosystem is situated along coastline and this ecosystem directly connected to coral reef ecosystem, mangrove trees species are dominance in this place are: Burguiera gymnorrhiza, Rhizophora apiculata and $R$. mucronata. The mean distances from the lowest tides to the nearest sampling area is approximately $182 \mathrm{~m}$. The substrates are formed by mixed sandy-mud and mixed sandy-gravels; the mean deepness of substrate is $36.1 \mathrm{~cm}$. Mean value of water variable, following as: salinity $37.8 \%$, DO 7.8, $\mathrm{pH} 8.2$, and temperature $30.5 \mathrm{C}^{0}$. 


\section{3) Station War Beki}

This area is connected to St. Kim Far, St. Tapor Pandera and the first War Beki Cove and the second Warbeki Cove. This station is connected with the sea grass ecosystem. There are several association species are present, such as Tetrameles nudiflora, Pometia Spp, Morinda citrifolia, Coccus spp, Artocarpus spp., Insia spp. and Ficus spp. Mangrove tree dominance in this place is Burguiera gymnorrhiza. However other mangrove species are Rhizopora mocronata, $R$. Stylosa, $R$. apiculata, and B. sexangula. The average distances from the lowest tides to the nearest sampling area is $5.8 \mathrm{~m}$., Substrates are forming by mixing clay-mud, muddy-clay, and there were a peace of flat rocky. The mean deepness of substrate is $48.7 \mathrm{~cm}$. Mean value of water variable, following as: salinity $18.8 \%$, $\mathrm{DO} 5, \mathrm{pH} 8.1$, and temperature $29.0 \mathrm{C}^{0}$.

\section{c. Mangrove Ecosystem Occupied the River System:}

The physical characteristics of ecosystem and mangroves composition in the river system are different with coastline and cove mangroves area in Gam Bay. Mostly, mangrove trees stand highest and more dominant by view species. I we go more deep in the river system we found a situation, when mangrove area are temporally not flood by seawater, if the highest tides occurred then seawater will reach that places. The rivers are often connected with freshwaters, for example: St. War Manak and St. War Beki.

1) Station War Manak:

The mangrove vegetation in this area is very dance and has highest stands. St. War Manak is dominances by the true mangrove tree species, such as Rhizopora mocronata and Burguiera sexangula. While the rivers system was across in from inlet, and was connected with freshwater. The type of substrates are consists by muddy and clay, then the substrate are cover by the flat rock formation. The average distances from the lowest tides to the nearest sampling area is about $24.2 \mathrm{~m}$. The average deepness of the substrate is $35.2 \mathrm{~cm}$. salinity 29.5\%, DO 8.9, pH 7.3, and temperature $29.2 \mathrm{C}^{0}$. 


\section{2) Station War Ongkor}

The War Ongkor Station has the same characteristics with St. War Manak, type mangroves vegetation is very dance and consists of highest mangrove trees. Two dominances of mangrove tree are Rhizopora mocronata and Burguiera sexangula. The distances from the lowest tides to the nearest sampling area is about $16.6 \mathrm{~m}$. Substrates are formed by muddy, the average deepness of substrate is $39.7 \mathrm{~cm}$, then substrate layers are covering flat rock formation. The averages water variable, such as: salinity $29.5 \%$, $\mathrm{DO} 9.2, \mathrm{pH} 8.0$, and temperature $29.0 \mathrm{C}^{0}$.

\section{d. Mangrove Ecosystem Occupied Coastlines:}

1) Station War Iprim:

This mangroves area is occurred along coastline, directly connected with sea grass and coral reef ecosystems. On the other hand this mangrove ecosystem is face strong current and wave from the sea, very near to villages, and has high human influences. Therefore this area has high risks for declining the ecosystem integrity and stability. There are two species are dominance in this area Burguiera gimnorrhiza and Sonneratia alba, and other mangrove species are: $R$. stylosa, R. apiculata, B.sexangula, and Aigiceras corniculatum. While the association species are Tetrameles nudiflora, Insia sp, Coccus spp, and Pongamia pinnata Merr. The distances from the lowest tides to the nearest sampling area is $6.9 \mathrm{~m}$. Substrates are forming by muddy and sandy, sandy-mud, muddy-sand-gravels, and muudy-sand. Then deepness of substrate is 37.2. Then water qualitiy, such as: salinity $36.3 \%$, DO 6.1, pH 7.9, and temperature $28.7 \mathrm{C}^{0}$.

2) Station Kapisawar:

This mangrove ecosystem get the highest rank of disturbances in comparison with other stations, due the position in between two villages, logging activities was take place in this area for village infrastructure at 5 years ago. Only one species is dominance in this area Sonneratia alba. The other mangrove species are present in area too, such as: A. floridum, B. gymnorrhiza, B. sexangula, R.stylosa, and $R$. apiculata. The average distances from the lowest tides to the 
nearest sampling area is $7.1 \mathrm{~m}$. Substrates are forming by muddy and sandy, sandy-mud, muddy-sand-gravels, and muudy-sand. The average value substrate deepness is 39.9 , and for water quality: salinity $36.3 \%$, DO 2.4, pH 7.9, and temperature $31.1 \mathrm{C}^{0}$

\section{3) Station War Beren:}

This station is similar to St. War Iprim and St. Kapisawar, where this station is directly connected with sea grass and coral reef ecosystems. There are four species of the true mangrove are dominance in this area, such as $S$. alba, R. stylosa, R. mucronata, and $R$. apiculata, other mangrove species are: $B$. gymnorrhhiza, B. sexangula, A. corniculatum, and $S$. caseolaris. The average distances from the lowest tides to the nearest sampling area is $5.7 \mathrm{~m}$. Substrates are formed by sandy, sandy-mud, sandy-gravels, muddyand flat rocky. The mean value substrate deepness is 26.9, Water quality: salinity $29.8 \%$, DO 6.8, pH 7.8, and temperature $28.5 \mathrm{C}^{0}$.

\section{The Habitat Characteristics}

Table 11. The Physical Characteristic in the Ten Stations in Gam Bay

\begin{tabular}{|l|c|c|c|c|c|l|l|}
\hline \multicolumn{1}{|c|}{ STATIONS } & S & DO & $\mathrm{pH}$ & $\mathrm{T}$ & DNSP & \multicolumn{1}{|c|}{ Substrates as crab habitat } & \multicolumn{1}{c|}{ Other crab habitat } \\
\hline St. Kapisawar & 36.3 & 2.4 & 7.9 & 31.1 & 7.1 & $\begin{array}{l}\text { Muddy, Muddy-sand, Muddy-sand- } \\
\text { gravels, Sandy, Sandy-mud }\end{array}$ & $\begin{array}{l}\text { The dead wood stem, } \\
\text { mangrove root }\end{array}$ \\
\hline St. War Ipirm & 36.3 & 6.1 & 7.9 & 28.7 & 6.9 & $\begin{array}{l}\text { Muddy, Muddy-sand, Muddy-sand- } \\
\text { gravels, Sandy, Sandy-mud }\end{array}$ & $\begin{array}{l}\text { The dead wood stem, } \\
\text { mangrove root }\end{array}$ \\
\hline St. War Beren & 29.8 & 6.8 & 7.8 & 28.5 & 5.7 & $\begin{array}{l}\text { Sandy, Sandy-gravels, Sandy-mud, } \\
\text { Muddy, Flat rocky }\end{array}$ & mangrove root \\
\hline St. Bun Iba & 33.3 & 5.2 & 7.9 & 29 & 7.2 & $\begin{array}{l}\text { Muddy, Sandy-mud, Sandy, Flat } \\
\text { rocky. }\end{array}$ & mangrove root \\
\hline St. Bun Mkun & 32.8 & 8.3 & 8.1 & 29.3 & 6 & Sandy, Sandy-mud, Muddy-sand & mangrove root \\
\hline $\begin{array}{l}\text { St. Tapor } \\
\text { Pandera }\end{array}$ & 32.8 & 9.1 & 7.9 & 29.3 & 6.2 & $\begin{array}{l}\text { Muddy, Muddy-sand, Sandy, } \\
\text { Sandy-mud }\end{array}$ & $\begin{array}{l}\text { The dead wood stem, } \\
\text { mangrove root }\end{array}$ \\
\hline St. Kim Far & 37.8 & 7.8 & 8.2 & 30.5 & 182 & Sandy-mud, Gravels-sand & mangrove root \\
\hline St. War Beki & 18.8 & 5 & 8.1 & 29 & 5.8 & $\begin{array}{l}\text { Muddy, Clay, Clay-muddy, } \\
\text { Muddy-clay, Flat rocky }\end{array}$ & $\begin{array}{l}\text { The dead wood stem, } \\
\text { mangrove root }\end{array}$ \\
\hline St. War Ongkor & 29.5 & 9.2 & 8 & 29 & 16.6 & Muddy & $\begin{array}{l}\text { The dead wood stem, } \\
\text { mangrove root }\end{array}$ \\
\hline St. War Manak & 29.5 & 8.2 & 7.3 & 29.2 & 24.2 & Muddy, Clay & $\begin{array}{l}\text { The dead wood stem, } \\
\text { mangrove root }\end{array}$ \\
\hline
\end{tabular}

Notes: All waters variables are the average values; DNSP is the distance from low tide to the nearest sampling point; $T$ is temperatures; $S$ is salinity; $S t$. is station

Within this observation it was investigated and classified several habitat base to the physical characteristic, the distribution pattern, and biology of mangrove forest in whole stations of Gam Bay (See Table 11). Mangrove crab habitat has been classified to be four types, such as: the mangrove root, dead 
stem, substrates, and flat rocky. Howe ever for the substrates alone, we classify to be six types, such as Muddy, Muddy-sand, Muddy-sand-gravels, Sandy, and Sandy-mud.

Those habitats providing extraordinary habitation for mangrove crab communities in Gam Bay. Ecologically, crabs will be adapted, developed, and performed their ability in order to live on those habitat, on other side that habitat has provides comfortable physical environment for crab communities it self. The physical characteristics of crab habitat would be described below:

\section{a. Mangrove Roots}

Base on the morphological adaptation of mangrove trees to the extreme environment, therefore their adapting their root shape to be several types sucha as aerial root, butters root, knee root, pneumatophore root, and stilt root. In Gam Bay, we have founded aerial root (Rhizophoraceae), knee root (Rhizophoraceae), pneumatophore root (Sonneratiaceae), and butters root (Rhizophoraceae), and stilt root (Sonneratiaceae). Mangroves roots system was formed a comfortable habitation for mangrove crabs (Appear in Table 11), mostly the climbing crabs are often present this habitat, for example Sesarmidae and Grapsidae crabs

b. Dead wood Stems

Dead wood is being comfortable habitat for crab communities (Appear in Table 11). In Gam Bay, we predicted that mangrove trees do not strong enough for the wind, because the mangrove root does not penetrate deep into substrates. Natural disturbances by strong wind can create gab by fallen mangrove trees. Naturally, the stem became decomposed and became smooth, it was easier for crabs occupying that stems, for example Sesarmidae crab, Grapsidae crabs, and Ocypodidae crab. There are many dead wood stems on the ground in several stations: St.War Iprim (Transect 01), St. Kapisawar (Transect 03 and Transect 04), St. War Beren (Transect 01), St. Taporpandera (Transect 01, Transect 02, Transect 03, and Transect 04), St. Warbeki (Transect 01, Transect 02, Transect 03, and Transect 04), and St. War Manak (Transect 03). 


\section{c. Substrates}

We are founded 12 various substrate in Gam Bay area, such as: clay substrate, clay-muddy substrate, flat rocky substrate, gravels-sand substrate, muddy substrate, muddy-clay substrate, muddy-sand substrate, muddy-sand-gravels substrate, sandy substrate, sandy-gravels substrate, sandy-gravels substrate, and sandy-mud substrate. Following table will show the substrates type in whole stations in Gam Bay (Appear in table 11).

\section{Mangrove Tree Community in Gam Bay, Raja Ampat Islands}

\section{Mangrove Tree Diversity}

The environment characteristic of Gam Bay preserve comfortable habitat for various mangrove tree species, there are two groups of mangroves such as true mangrove species and association mangrove species. We found 5 families, 9 genus, and 15 species of true mangrove tree (See Tabel 12). We also indentify 10 families of association mangrove, 10 genus, and 10 species (appear in Table 13). Commonly the associate mangroves are positioned in between the highest tide and low tide point, Therefore, the assocoted mangroves are usually can be faund together with the true mangrove species in between lowesthightest tides area.

Table 12. The Diversity of True Mangrove Species

\begin{tabular}{|l|l|c|c|}
\hline \multicolumn{1}{|c|}{ Family } & \multicolumn{1}{c|}{ Genus } & \multicolumn{1}{c|}{$\begin{array}{c}\text { Number of } \\
\text { Species }\end{array}$} & $\begin{array}{c}\text { Number of } \\
\text { Individual }\end{array}$ \\
\hline Arecaceae & Nypa & 1 & 6 \\
\hline Euphorbiaceae & Excoecaria & 1 & 5 \\
\hline Meliaceae & Xylocarpus & 1 & 1 \\
\hline Myrsinaceae & Aegiceras & 2 & 19 \\
\hline Rhizophoraceae & Bruguiera & 2 & 278 \\
\hline Rhizophoraceae & Ceriops & 2 & 37 \\
\hline Rhizophoraceae & Rhizophora & 3 & 146 \\
\hline Rubiaceae & Scyphiphora & 1 & 1 \\
\hline Sonneratiaceae & Sonneratia & 2 & 92 \\
\hline \multicolumn{1}{c|}{9} & \multicolumn{1}{c|}{9} & 15 & 585 \\
\hline
\end{tabular}


Table 13. The Diversity of Mangrove Associate Species

\begin{tabular}{|l|l|c|c|}
\hline \multicolumn{1}{|c|}{ Family } & \multicolumn{1}{|c|}{ Genus } & \multicolumn{1}{c|}{$\begin{array}{c}\text { Number of } \\
\text { Species }\end{array}$} & $\begin{array}{c}\text { Number of } \\
\text { Individual }\end{array}$ \\
\hline Arecaceae & Cocos & 1 & 8 \\
\hline Moraceae & Ficus & 1 & 5 \\
\hline Tetramelaceae & Tetrameles & 1 & 3 \\
\hline Leguminosae & Pongamia & 1 & 6 \\
\hline Anacardiaceae & Mangifera & 1 & 3 \\
\hline Fabaceae & Intsia & 1 & 4 \\
\hline Guttiferae & Calophyllum & 1 & 2 \\
\hline Moraceae & Artocarpus & 1 & 1 \\
\hline Rubiaceae & Morinda & 1 & 5 \\
\hline Sapindaceae & Pometia & 1 & 1 \\
\hline \multicolumn{1}{|c|}{10} & 10 & 10 & 38 \\
\hline
\end{tabular}

Base on the Nature Conservancy (2003) the total mangroves species in Raja Ampat is about 25 species (See appendix 2a). However it does not include Ceriops decandra (See appendix 2b), therefore Ceriops decandra is the new species for the Raja Ampat Island, then the total number of species became 26. This species C. decandra are distributed in St. Bun Mkun, St. Tapor Pandera, and St. Kim Far.

While sp $\mathrm{Z}$ as an associate mangrove species still unknown species, therefore the associate species became 11 (See Table 15). Probably, the number of the true mangrove species are more than 15 species, because there are several places was not include the sampling area it is mean those places might provide different species too, yet we not count all species in a line, only four nearest trees from the center point.

About $58 \%$ of them or 15 from 26 true mangrove species are available in Gam Bay Island, and the comparison the number of mangroves diversity in Gam Bay toward the world mangroves diversity and others areas has showed in the figure 7. Belong to the Shannon-Wiener index where the mangrove diversity value in Gam Bay is moderate or 2.411 and the Simpson index is high or 0.854 , than the Margalef index has showing the moderate status of species richness or 3.884 . 


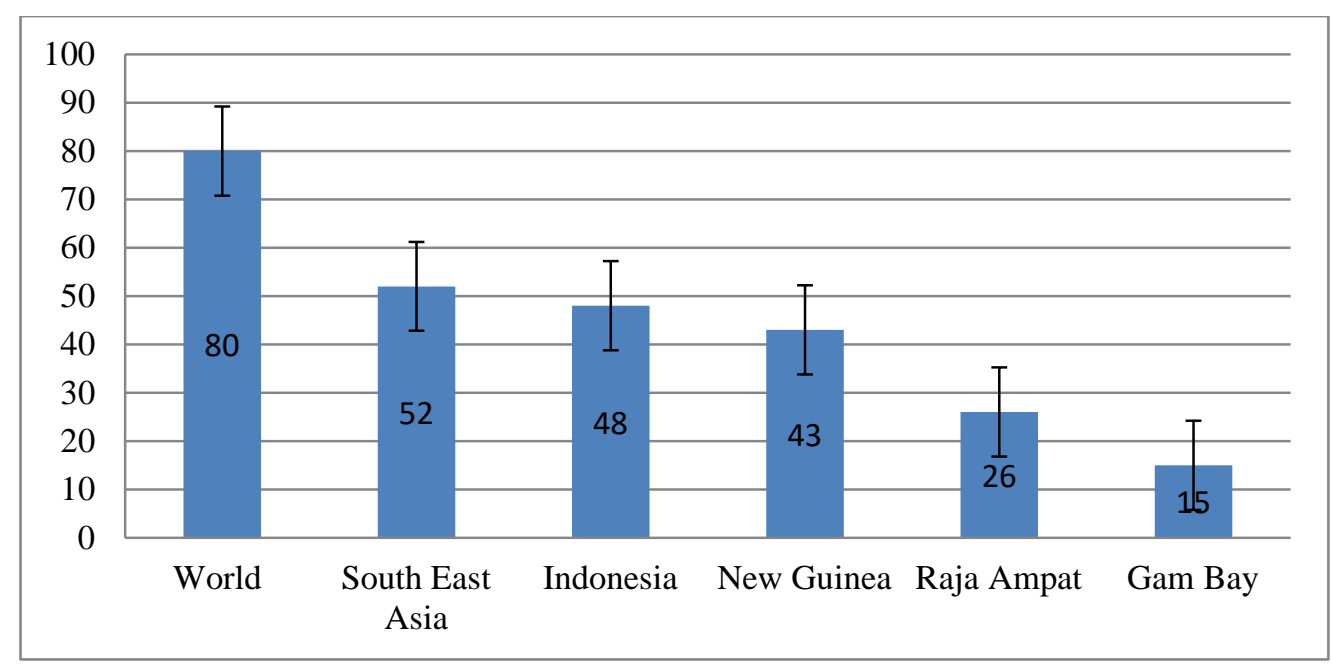

Figure 7. The Camparison of Mangroves Diversity in Gam Bay

Ten stations in Gam Bay region was showing different status of diversity, it is appear in table 14. For example St. War Ongkor has poor diversity status and richnees status base to Shannon-Wiener and Margalef calculation, however if we use the Simpson index then we got moderate status appear in table 14. Possible reason for the diversity status of St War Ongkor base to both indices are due to the zonation pattern of mangrove ecosystem, dominance species are concentrated in particular sampling site or transect line, and the physical characteristic of mangroves forest itself.

Table 14. The Diversity Values of Mangrove Tree Species

\begin{tabular}{|l|c|c|c|c|c|c|}
\hline \multicolumn{1}{|c|}{ Station } & $\begin{array}{c}\text { Sahnnon- } \\
\text { Wiener }\end{array}$ & $\begin{array}{c}\text { Diversity } \\
\text { Status }\end{array}$ & Simpson & $\begin{array}{c}\text { Diversity } \\
\text { Status }\end{array}$ & Margalef & $\begin{array}{c}\text { Richness } \\
\text { Status }\end{array}$ \\
\hline St. Kapisawar & 1.639 & Moderate & 0.534 & Moderate & 1.526 & Poor \\
\hline St. War Ipirm & 1.994 & Moderate & 0.591 & Moderate & 2.404 & Moderate \\
\hline St. War Beren & 3.181 & High & 0.879 & High & 2.885 & Moderate \\
\hline St. Bun Iba & 2.246 & Moderate & 0.730 & High & 2.172 & Moderate \\
\hline St. Bun Mkun & 2.397 & Moderate & 0.793 & High & 1.443 & Poor \\
\hline St. Tapor Pandera & 2.598 & Moderate & 0.814 & High & 1.924 & Poor \\
\hline St. Kim Far & 1.753 & Moderate & 0.612 & Moderate & 0.962 & Poor \\
\hline St. War Beki & 3.204 & High & 0.863 & High & 2.896 & Moderate \\
\hline St. War Ongkor & 0.835 & Poor & 0.396 & Moderate & 0.240 & Poor \\
\hline St. War Manak & 1.304 & Moderate & 0.535 & Moderate & 0.721 & Poor \\
\hline
\end{tabular}

Notes: St. is station 


\section{Mangrove Trees Distribution}

If a particular mangrove species is naturally introduced into new environment, and that species can be able to survive, grow, and reproduce in their new environment. It means that species has been succesfull adapted and distributed to the characteristic of that environment, in the other word that species is matching with the new environment. However, every single species has exclusive adaptation and distribution ability, we have found not all mangroves can be able to occupy ten stations in Gam Bay, several stations has great number of species, some moderate and view are poor species (Appear in Table 14). Therewere three stations has high number of mangrove species, such as St. War Iprim (11 species), St. War Beren (13 species) and St. Warbeki (species).

Zonation pattern of mangrove vegetation in particular station is also contributed to the availibelity of mangroves species. We have found some station has unclear zanation, such as, St. Kapisawar, War Beren, St. War Iprim, St. War Beki, Bun Iba, and Bun Mkun. Than stations with clear zonation pattern, such as: St War Ongkor, St.Kim Far and St. Warmanak. For example, if the line transect was establish in the zone where B. gymnorrhiza (L.) Lamk and B. mucronata occupying than only both species are available. Those circumstances occurred in St. War Ongkor, War Manak and St. Kim Far. While in stations were the mangrove vegetation does not too broad, we found various mangrove species, the dominance species does not appear, and presence of associate species.

Both species Bruguiera sexangula (Lour.) Poir and Bruguiera gymnorrhiza (L.) Lamk, distributed in entire Gam Bay region. B. sexangula (L.) are occupying $90 \%$ of ten stations, while B. gymnorrhiza (L.) is $80 \%$, following by Rhizopra apiculta (BI) is $70 \%$, R. stylosa (G) and Sonneratia alba (J.) are 60\% (appear in Figure 8 and Table 15). It is indicated those species has good adaptation ability and dispersal ability, this factor was including the intrinsic factor of distribution. 
Table 15. The Distribution of the True Mangrove and Mangrove Associated Species at Ten Station in Gam Bay

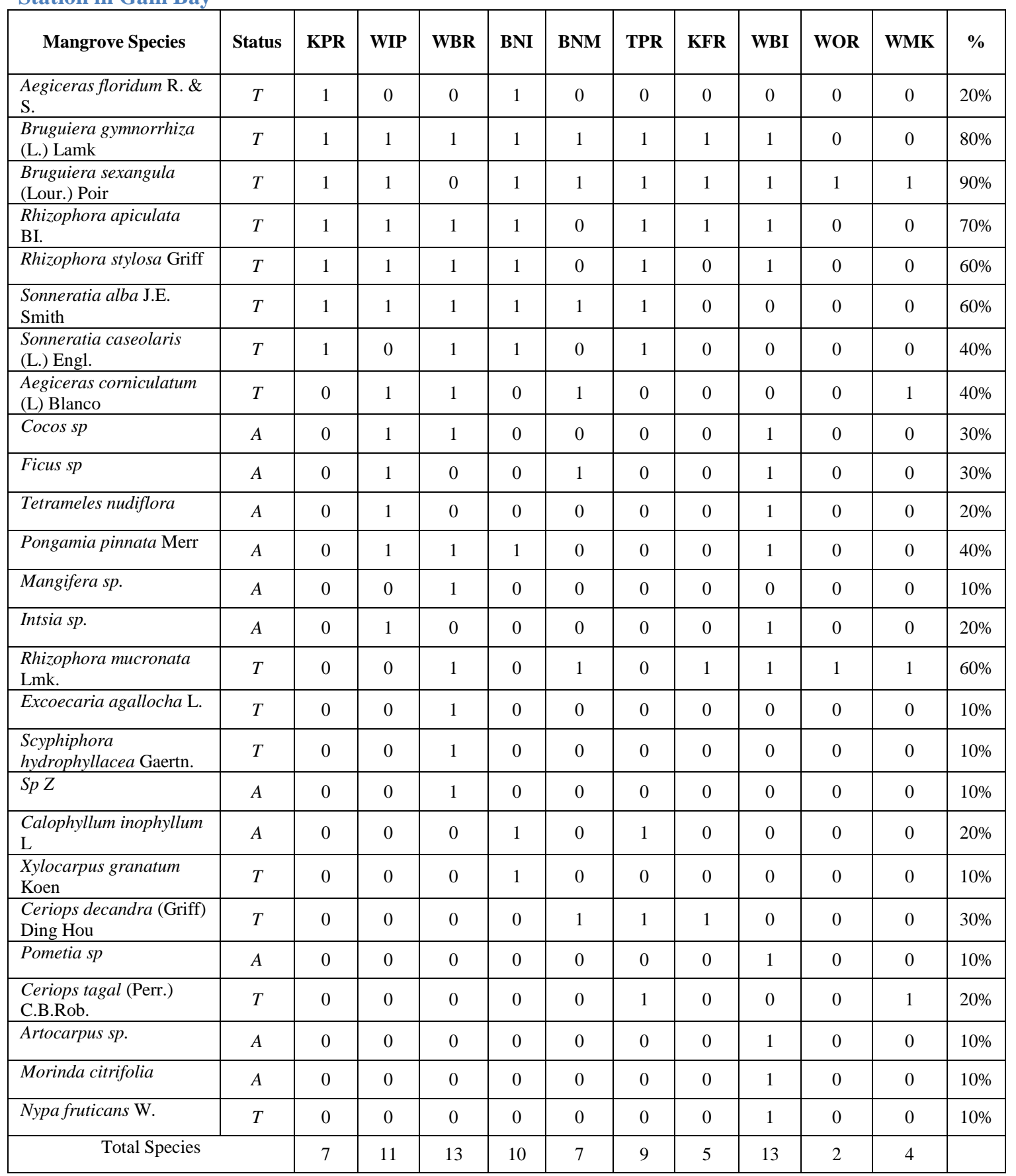

Notes: $K P R$ is Station Kapisawar; WIP is Station War Iprim; WBR is Station War Beren; BNI is Station Bun Iba; BNM is Station Bun Mkun; TPR is Station Tapor Pandera; KFR is Station Kim Far; WBI is Station War Beki; WOR is Station War Ongkor, WMK is Station War Manak. Then 1 is the availability of species, $O$ is the species available of species in a station. $T$ is the true mangrove species; $A$ is mangrove associate species 
Human internvention in several stations are contributed to the availability of associated mangrove species by traditional gardens activities. For example, Cocos sp are presence in St. War Iprim, St. War Manak, and St. War Beki, and Mangifera sp is available in St. War Manak (Table 15). The other factor is the phisycal characteristic of mangrove ecosystem at station is allowed the propogules for being distributed and dispersaled.

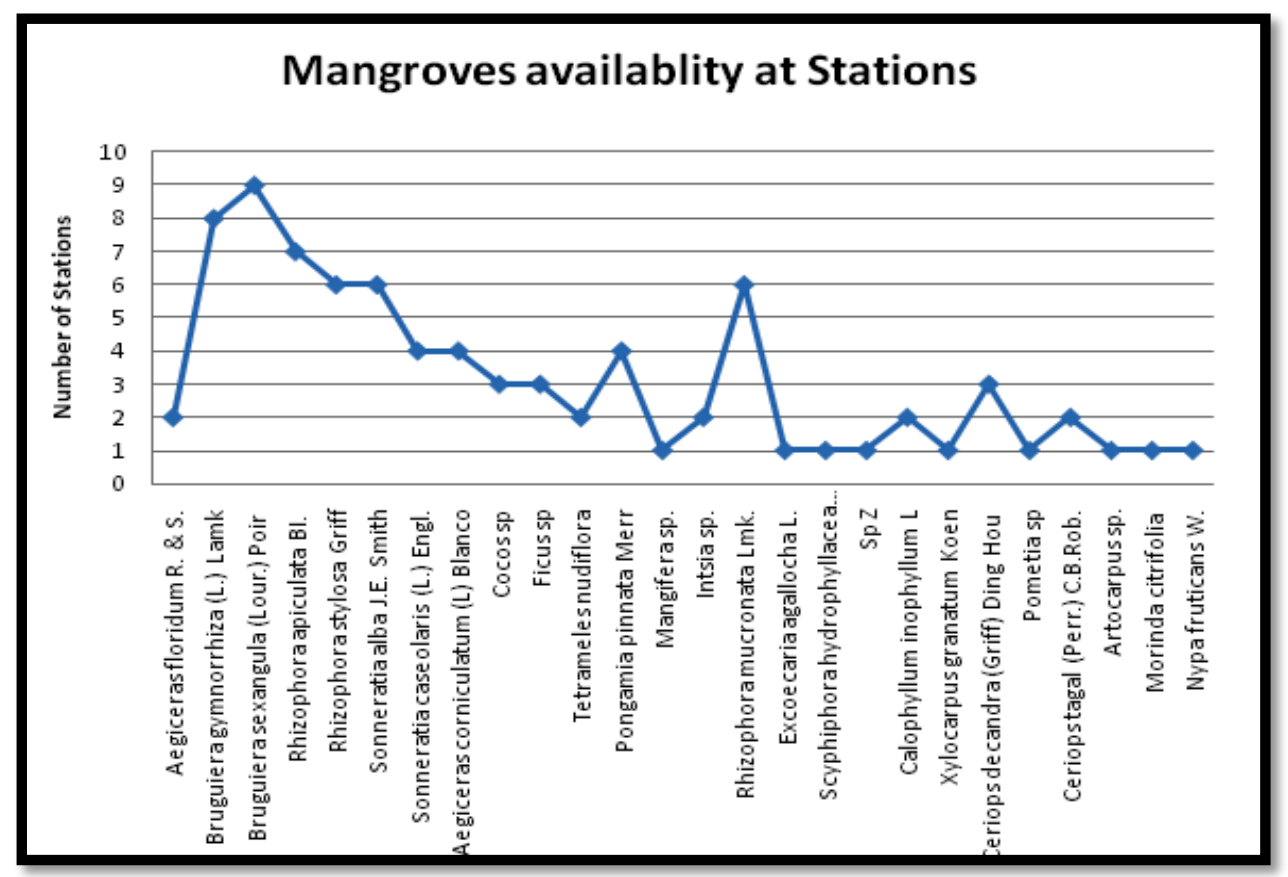

Figure 8.Mangroves Availability at Stations in Gam Bay

\section{Mangrove Trees Density}

New individual can be added to populations in two ways, by birth or regeneration and by immigration (Brewer, 1994). These two factors are playing very important contribution rate of population growth. Plants maintain and expand their population over time by the process of regeneration, for example if we talk about regeneration it was includes seed production and the maturation of seeds (Barnes et al., 1997), so with these two components plants ready to be dispersed. However, not only two factors but there are many factors were contributed to the density of population, such as climate, light, temperature, physiography, soil, site quality (Barnes et al., 1997). 
If individuals are able to survive, grow, and reproduce and their population was growing rapidly indicated that their environments has given better support (Krebs, 1985), however a population will growth until the maximum size or achieve the carrying capacity, then goes down or being slowly (Barnes et al., 1997). In order to regocnize the population growth we can measure the population size and number of individual per unit space or so called density. Whitin this research we did calculation of density value of mangroves at ten stations in Gam Bay area (Table 16).

Table 16. The Density Value of Mangrove Trees
\begin{tabular}{|l|c|}
\hline \multicolumn{1}{|c|}{ Station } & Mangrove Density \\
\hline St. Kapisawar & 487.013 \\
\hline St. War Ipirm & 539.264 \\
\hline St. War Beren & 479.733 \\
\hline St. Bun Iba & 444.549 \\
\hline St. Bun Mkun & 927.032 \\
\hline St. Tapor Pandera & 571.135 \\
\hline St. Kim Far & 891.067 \\
\hline St. War Beki & 433.454 \\
\hline St. War Ongkor & 649.631 \\
\hline St. War Manak & 1524.762 \\
\hline Average & 694.764 \\
\hline
\end{tabular} Notes: St. is station; the value is the number of individual per ha.

The number of density in a mangrove population is affected by more than one factor. All factors are including the density-dependent factors and density-independent factors. Possibellity the density dependent factors, such as competition for resources, crowding population, and stress. The densityindependent factors such as natural disasters like hurricances and fire, physical characteristics, and human activities.

For example human activies, we have classifying the station by distances to the village. We have found these stations; St. Kapisawar, St. War Iprim, and St. War Ongkor are very near to villages. However St. Kapisawar alone has not distance at all with the villages that why, this station has a lot disturbances more than other stations. Eventhought, St. Kapisawar still has a moderate status of mangrove diversity (Appear in Table 14), but the human activities have changed the mangrove communities in that stations. 


\section{Mangrove Crabs Community in Gam Bay, Raja Ampat Islands}

\section{Mangrove Crab Diversity}

Within this research we success to indentify 4 super families, 7 families, 14 genus and 53 species of mangrove crabs (appear in table 17 and table 18, see also appendix 03). There are three predators species, Myomenippe sp, Epixanthus dentatus (white, 1847), Ocypode pallidula (Jacquinot, 1852), and two migratory species Thalamita creanata (Latreille, 1829) and Myomenippe $s p$. Those predator species are usually appear together with uca spp, while $T$. creanata are often available in sea grass ecosystem.

Table 17. Diversity of Mangrove Crab Species

\begin{tabular}{|l|l|l|l|c|c|}
\hline Infraorder & Super Family & \multicolumn{1}{|c|}{ Family } & \multicolumn{1}{c|}{ Genus } & $\begin{array}{c}\text { Number of } \\
\text { Species }\end{array}$ & $\begin{array}{c}\text { Number of } \\
\text { Individual }\end{array}$ \\
\hline Brachyura & Ocypodoidea & Dotillidae & Ilyoplax & 1 & 12 \\
\hline Brachyura & Eriphioidea & Eriphiidae & Epixanthus & 1 & 2 \\
\hline Brachyura & Eriphioidea & Eriphiidae & Myomenippe & 1 & 7 \\
\hline Brachyura & Grapsoidea & Glyptograpsidae & Metopograpsus & 2 & 156 \\
\hline Brachyura & Ocypodoidea & Macrophthalmidae & Macrophthamus & 2 & 10 \\
\hline Brachyura & Ocypodoidea & Ocypodidae & Ocypode & 1 & 2 \\
\hline Brachyura & Ocypodoidea & Ocypodidae & Uca & 27 & 1818 \\
\hline Brachyura & Portunidae & Portunoidae & Thalamita & 1 & 11 \\
\hline Brachyura & Grapsoidea & Sesarmidae & Parasesarma & 12 & 447 \\
\hline Brachyura & Grapsoidea & Sesarmidae & Perisesarma & 2 & 368 \\
\hline Brachyura & Grapsoidea & Sesarmidae & Sarmatium & 1 & 1 \\
\hline Brachyura & Grapsoidea & Sesarmidae & Selatium & 2 & 12 \\
\hline 1 & 4 & 7 & 12 & 53 & 2846 \\
\hline
\end{tabular}

The values of Shannon-Wiener and Simpson diversity indices showing all station has moderate to high status of species diversity (appear table 18) and the Margalef index showing various status of species richness among ten stations. Over all, there were 53 species, and 2846 individual of mangrove crabs, and then we had the values of Shannon-Wiener is about 4.823, Simpson index is about 0,954, and Margalef index is about 6.538, it is maen the mangrove crabs diversity in Gam Bay is very high and very rich.

The value of both diversity indices could be indicated mangrove ecosystem in entire Gam Bay region are comfortable and then the diversity habitat is suitable in order to support the crabs communities and mangroves community, afterward we will disscuss more detail in the chapter discussion. 
By use visual observation surrounding Gam Bay, it was appearing other group of crabs, such as seagrass crabs, land crabs, and coral reef crabs. Surely, those groups of crabs have a particulary number of diversity. For example if we wants to count those groups in the bumber of crab diversity, then we will found greatest number of crab biodiversity.

Table 18. The Diversity Value of Mangrove Crab Species

\begin{tabular}{|l|c|c|c|c|c|c|}
\hline \multicolumn{1}{|c|}{ Station } & $\begin{array}{c}\text { Sahnnon- } \\
\text { Wiener }\end{array}$ & $\begin{array}{c}\text { Diversity } \\
\text { Status }\end{array}$ & Simpson & $\begin{array}{c}\text { Diversity } \\
\text { Status }\end{array}$ & Margalef & $\begin{array}{c}\text { Species } \\
\text { Richness }\end{array}$ \\
\hline St. Kapisawar & 3.709 & High & 0.873 & High & 4.475 & High \\
\hline St. War Ipirm & 3.494 & High & 0.876 & High & 3.693 & Moderate \\
\hline St. War Beren & 3.331 & High & 0.823 & High & 4.164 & High \\
\hline St. Bun Iba & 3.65 & High & 0.908 & High & 3.76 & Moderate \\
\hline St. Bun Mkun & 2.77 & Moderate & 0.79 & High & 2.829 & Moderate \\
\hline St. Tapor Pandera & 3.732 & High & 0.891 & High & 4.141. & High \\
\hline St. Kim Far & 1.865 & Moderate & 0.668 & Moderate & 1.198 & Poor \\
\hline St. War Beki & 3.627 & High & 0.894 & High & 3.595 & Moderate \\
\hline St. War Ongkor & 2.418 & Moderate & 0.771 & High & 1.568 & Poor \\
\hline St. War Manak & 1.786 & Moderate & 0.661 & Moderate & 0.931 & Poor \\
\hline Average & 3.0382 & High & 0.815 & High & 2.912 & Moderate \\
\hline
\end{tabular}

\section{Mangrove Crab Distribution}

The spatial structure of a population has three main properties: distribution, dispersion, and density (Ricklefs, 1990). The distribution of population is its geogphical and ecological range, determined primarly by the presence or obsence suitable habitat condition, and also other limiting factors like food, predation and population size (Krebs, 1985). An individual will be found only where the habitat is suitable, if the habitat does not suitable than individuals is moved to others possible habitat or do immigration. Some mangrove crabs are the migratory species. They can move from one ecosystem to another ecosystem, for example Thalamita creanata (Latreille, 1829), this crab also found in the nearst sea grass ecosystem, while Myomenippe $s p$ often appeared in the coast-land. Some crabs also move from one microhabitat to another microhabitat for example Selatium spp and Metopograpsus frontalis (Miers, 1880), they are the climbing crabs which usually doing feeding activity together with $U c a$ spp.

The data of crab distribution show that the various home range of mangrove crabs species in the ten stations in Gam Bay region (Appear in Table 
19). There are three species has good ability for being distributed: Uca crassipes (White, 1847), U. perplexa (H. Milne Edwards, 1852), and Parasesarma sp 07. These crabs are occupying $70 \%$ of ten stations in Gam Bay region (appear in table 19), and probably has good adaptation abilities, on the other words they have large home range such as Following by Uca sp 02, U. crassipes, Uca sp 06, Uca sp 07, Uca sp 20, Uca sp 21, U. triangularis, Parasesarma sp 02, Parasesarma sp 08, and Metopograpsus frontalis, these crabs occupy $60 \%$ of ten stations. There are nine species found only in one stations, such as Uca sp 08, Uca sp 16, U.jocelynae, Uca sp 23, Uca sp 26, Sermatium cassum, Selatium sp 01, Parasesarma sp 09, and Parasesarma sp 12. These species are probably represented a species which has low ability to adaptation, in other words exclusive species in particular habitat.

\section{Mangrove Crab Density}

The dynamics of population describe the changing of individual number over time and space (Ricklefs, 1990), hence called population dynamic. Therefore to measure the density a reasearcher have to have to found an ideals environment condition and season to measure the species density. Density itself is an important property of a population because it indicates the potential intensity of interaction among individuals (Ricklefs, 1990). Within these interactions are reflecting to the structure of community. The physical environment itself includes many factors important to the well-being of the organism, for example salinity, water, oxygen, temperature, subtrates, and so on.

Population growth declines because of death rate increase, birth rate decrease or both. There is a reduction in the food supply which restricts reproduction resulting in less offspring. The competition for space to establish territories is a behavioral mechanism that may restrict population growth. Predators concentrate in areas where there is a high concentration of prey. As long as the natural resources are available, in sufficient quantity, the population will remain constant. As the population decreases so do the predators. The accumulation of toxic wastes may also limit the size of a population. Intrinsic factors may play a role in limiting a population size. 
Table 19. The Distribution of Mangrove Crab Species at Ten Station in Gam Bay

\begin{tabular}{|c|c|c|c|c|c|c|c|c|c|c|c|c|}
\hline Code & Species & KPR & WIP & WBR & BNI & BNM & TPR & KFR & WBI & WOR & WMK & $\%$ \\
\hline SP 01 & $\begin{array}{l}\text { Uca sp 01/Uca crassipes } \\
\text { (White, 1847) }\end{array}$ & 1 & 1 & 1 & 1 & 1 & 1 & 0 & 1 & 0 & 0 & $70 \%$ \\
\hline SP 02 & Uca sp 02 & 1 & 1 & 1 & 1 & 0 & 1 & 0 & 1 & 0 & 0 & $60 \%$ \\
\hline SP 03 & Uca sp 03 & 1 & 0 & 1 & 0 & 1 & 1 & 0 & 0 & 0 & 0 & $40 \%$ \\
\hline SP 04 & Uca sp 04 & 1 & 1 & 1 & 0 & 0 & 1 & 0 & 0 & 0 & 0 & $40 \%$ \\
\hline SP 05 & $\begin{array}{l}\text { Uca sp 05/ Uca crassipes } \\
\text { (Adams \& White, 1848) }\end{array}$ & 1 & 1 & 1 & 1 & 1 & 0 & 0 & 1 & 0 & 0 & $60 \%$ \\
\hline SP 06 & Uca spp 06 & 1 & 1 & 1 & & 1 & 1 & 0 & 1 & 0 & 0 & $60 \%$ \\
\hline SP 07 & Uca sp 07 & 1 & 1 & 1 & 1 & 1 & 1 & 0 & 0 & 0 & 0 & $60 \%$ \\
\hline SP 08 & Parasesarma sp 01 & 1 & 1 & 1 & 0 & 0 & 0 & 1 & 1 & 0 & 0 & $50 \%$ \\
\hline SP 09 & Uca sp 08 & 1 & 0 & 0 & 0 & 0 & 0 & 0 & 0 & 0 & 0 & $10 \%$ \\
\hline SP 10 & Uca sp 09 & 1 & 0 & 1 & 0 & 0 & 0 & 0 & 0 & 0 & 0 & $20 \%$ \\
\hline SP 11 & Uca sp 10 & 1 & 1 & 1 & 0 & 0 & 1 & 0 & 1 & 0 & 0 & $50 \%$ \\
\hline SP12 & $\begin{array}{l}\text { Uca sp 11/ U. perplexa }(\mathrm{H} . \\
\text { Milne Edwards, 1852) }\end{array}$ & 1 & 0 & 1 & 0 & 0 & 0 & 0 & 0 & 0 & 0 & $20 \%$ \\
\hline SP 13 & Parasesarma sp 02 & 1 & 1 & 0 & 1 & 1 & 1 & 0 & 1 & 0 & 0 & $60 \%$ \\
\hline SP 14 & Uca sp 12 & 1 & 1 & 1 & 1 & 1 & 1 & 0 & 1 & 0 & 0 & $70 \%$ \\
\hline SP 15 & Parasesarma sp 03 & 1 & 0 & 1 & 1 & 0 & 0 & 0 & 1 & 0 & 0 & $40 \%$ \\
\hline SP 16 & Parasesarma sp 04 & 1 & 0 & 1 & 0 & 0 & 1 & 0 & 1 & 0 & 0 & $40 \%$ \\
\hline SP 17 & Uca sp 13 & 1 & 0 & 1 & 0 & 0 & 0 & 0 & 1 & 0 & 0 & $30 \%$ \\
\hline SP 18 & Uca sp 14 & 1 & 1 & 0 & 1 & 0 & 0 & 0 & 0 & 0 & 0 & $30 \%$ \\
\hline SP 19 & Uca sp 15 & 1 & 0 & 1 & 0 & 0 & 0 & 0 & 1 & 0 & 0 & $30 \%$ \\
\hline SP 20 & Parasesarma sp 05 & 1 & 0 & 0 & 1 & 1 & 1 & 1 & 0 & 0 & 0 & $50 \%$ \\
\hline SP 21 & Uca sp 16 & 1 & 0 & 0 & 0 & 0 & 0 & 0 & 0 & 0 & 0 & $10 \%$ \\
\hline SP 22 & $\begin{array}{l}\text { Uca sp 17/ Uca tetragonon } \\
\text { (Herbst, 1790) }\end{array}$ & 1 & 0 & 1 & 0 & 0 & 0 & 0 & 1 & 0 & 0 & $30 \%$ \\
\hline SP 23 & Parasesarma sp 06 & 1 & 1 & 0 & 0 & 0 & 0 & 0 & 1 & 0 & 0 & $30 \%$ \\
\hline SP 24 & $\begin{array}{l}\text { Uca sp 18/ Uca dussumieri } \\
\text { (H. Milne Edwards, 1852) }\end{array}$ & 1 & 0 & 1 & 0 & 0 & 1 & 0 & 1 & 0 & 0 & $40 \%$ \\
\hline SP 25 & $\begin{array}{l}\text { Uca spp 19/ } \\
\text { U. jocelynae Shih }\end{array}$ & 1 & 0 & 0 & 0 & 0 & 0 & 0 & 0 & 0 & 0 & $10 \%$ \\
\hline SP 26 & Macrophthalmus sp 01 & 1 & 0 & 0 & 0 & 0 & 0 & 0 & 0 & 0 & 0 & $10 \%$ \\
\hline Sp 27 & Uca sp 20 & 1 & 1 & 0 & 1 & 1 & 1 & 0 & 1 & 0 & 0 & $60 \%$ \\
\hline Sp 28 & $\begin{array}{l}\text { Ocypode pallidula } \\
\text { (Jacquinot,1852) }\end{array}$ & 1 & 0 & 1 & 0 & 0 & 0 & 0 & 0 & 0 & 0 & $20 \%$ \\
\hline SP 29 & Uca sp 21 & 1 & 1 & 0 & 0 & 0 & 1 & 0 & 1 & 1 & 1 & $60 \%$ \\
\hline SP 30 & Parasesarma sp 07 & 0 & 1 & 0 & 0 & 1 & 1 & 1 & 1 & 1 & 1 & $70 \%$ \\
\hline SP 31 & $\begin{array}{l}\text { Sarmatium cassum (Dana, } \\
1851 \text { ) }\end{array}$ & 0 & 1 & 0 & 0 & 0 & 0 & 0 & 0 & 0 & 0 & $10 \%$ \\
\hline SP 32 & Parasesarma sp 08 & 0 & 1 & 0 & 1 & 1 & 1 & 0 & 0 & 1 & 1 & $60 \%$ \\
\hline SP 33 & $\begin{array}{l}\text { Uca sp 22/Uca } \\
\text { triangularis }\end{array}$ & 0 & 1 & 1 & 0 & 1 & 1 & 0 & 1 & 1 & 0 & $60 \%$ \\
\hline SP 34 & Epixanthus dentatus & 0 & 1 & 0 & 0 & 0 & 0 & 0 & 0 & 1 & 0 & $20 \%$ \\
\hline SP 35 & Metopograpsus sp 01 & 0 & 1 & 0 & 1 & 0 & 1 & 0 & 0 & 0 & 0 & $30 \%$ \\
\hline SP 36 & Uca sp 23 & 0 & 0 & 1 & 0 & 0 & 0 & 0 & 0 & 0 & 0 & $10 \%$ \\
\hline SP 37 & Uca sp 24 & 0 & 1 & 0 & 0 & 0 & 0 & 0 & 1 & 1 & 0 & $30 \%$ \\
\hline SP 38 & Uca sp 25 & 0 & 0 & 1 & 1 & 0 & 1 & 0 & 1 & 0 & 0 & $40 \%$ \\
\hline SP 39 & $\begin{array}{l}\text { Macrophthalmus sp } 02 \\
\text { (Wada and Sakai, 1989) }\end{array}$ & 0 & 1 & 1 & 0 & 0 & 0 & 0 & 1 & 0 & 0 & $30 \%$ \\
\hline SP 40 & Ilyoplax sp & 0 & 0 & 1 & 0 & 0 & 1 & 0 & 1 & 0 & 0 & $30 \%$ \\
\hline SP 41 & Thalamita creanata & 0 & 0 & 0 & 1 & 0 & 0 & 1 & 1 & 0 & 0 & $30 \%$ \\
\hline SP 42 & Selatium sp 01 & 0 & 0 & 0 & 0 & 0 & 0 & 0 & 1 & 0 & 0 & $10 \%$ \\
\hline $\mathrm{Sp} 43$ & Parasesarma sp 09 & 0 & 0 & 0 & 1 & 0 & 0 & 0 & 0 & 0 & 0 & $10 \%$ \\
\hline SP 44 & Parasesarma sp 10 & 0 & 0 & 0 & 1 & 0 & 0 & 0 & 0 & 0 & 0 & $10 \%$ \\
\hline SP 45 & Uca sp 26 & 0 & 0 & 0 & 1 & 0 & 0 & 0 & 0 & 0 & 0 & $10 \%$ \\
\hline SP 46 & Uca sp 27 & 0 & 0 & 0 & 1 & 1 & 1 & 0 & 0 & 0 & 0 & $30 \%$ \\
\hline SP 47 & $\begin{array}{l}\text { Metopograpsus sp 02/ } \\
\text { Metopograpsus frontalis }\end{array}$ & 0 & 0 & 1 & 1 & 1 & 1 & 1 & 0 & 1 & 0 & $60 \%$ \\
\hline SP 48 & Parasesarma sp 11 & 0 & 0 & 0 & 0 & 1 & 1 & 0 & 0 & 1 & 0 & $30 \%$ \\
\hline SP 49 & Perisesarma sp 01 & 0 & 0 & 0 & 0 & 0 & 1 & 1 & 0 & 0 & 0 & $20 \%$ \\
\hline SP 50 & Myomenippe sp & 0 & 0 & 1 & 0 & 0 & 1 & 0 & 0 & 0 & 0 & $20 \%$ \\
\hline SP 51 & Perisesarma sp 02 & 0 & 0 & 0 & 0 & 0 & 0 & 0 & 0 & 1 & 1 & $20 \%$ \\
\hline SP 52 & Selatium sp 02 & 0 & 0 & 0 & 0 & 0 & 0 & 0 & 0 & 1 & 1 & $20 \%$ \\
\hline SP 53 & Parasesarma sp 12 & 0 & 0 & 0 & 0 & 0 & 0 & 0 & 0 & 0 & 1 & $10 \%$ \\
\hline \multicolumn{2}{|c|}{ Total Species } & 29 & 22 & 26 & 19 & 14 & 25 & 6 & 25 & 10 & 6 & \\
\hline
\end{tabular}

Notes: $K P R$ is Station Kapisawar; WIP is Station War Iprim; WBR is Station War Beren; $B N I$ is Station Bun Iba;

BNM is Station Bun Mkun; TPR is Station Tapor Pandera; KFR is Station Kim Far; WBI is Station War Beki; WOR is Station War Ongkor, WMK is Station War Manak. Then 1 is the availability of species, 0 is the species available of species in a station. 
The average crab density at ten stations show different numbers of individual per hectare (Appear in table 20 and figure 9), it indicated each station has different environmental characteristics. While each characteristic of mangrove environmental performs different contribution for the number of individual per unit space. In order to find a station is more suitable for crabs, we have to explore more about the physical characteristic and the level of disturbances on every stations, and migh be more deep in biological factors, and also the response of crabs to their environment.

The density of species is naturally not constant. It's followed the changing of environmental conditions due to individual response whitin a community. In reality, might be too difficult to found a stable environment without external disturbances, whitin this study we have the level of disturbance of ten stations in Gam Bay, and then we can understand that the number crab density has influences by external disturbances in particular level, it might be change the density of crab over time.

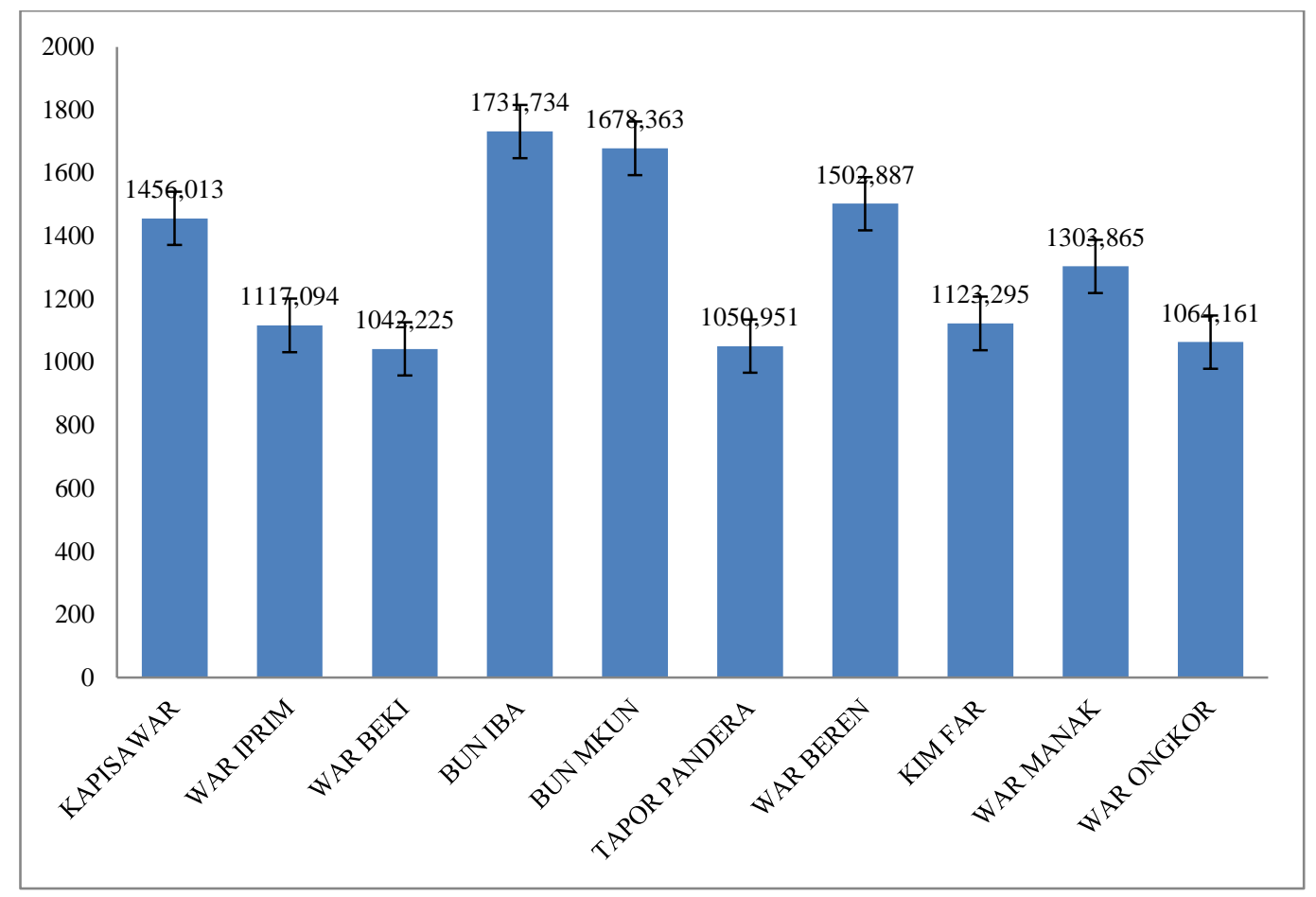

Figure 9. Average of Mangrove Crab Density at Ten Station 
Table 20. Mangrove Crabs Density at Ten Stations in Gam Bay

\begin{tabular}{|c|c|c|c|c|c|c|c|c|c|c|c|c|c|}
\hline $\begin{array}{l}\text { Species } \\
\text { ID }\end{array}$ & Name of Species & KPR & WIP & WBI & BNI & BNM & TPR & WBR & KFR & WMK & WOR & SUM & AVARAGE \\
\hline SP 01 & Uca sp 01/Uca crassipes (White, 1847) & 6296.200 & 639.800 & 639.800 & 8284.60 & 477.57 & 2094.4 & 318.37 & - & - & - & 18750.740 & 2678.677 \\
\hline SP 02 & Uca sp 02 & 1377.800 & 2062.000 & 2062.000 & 442.10 & - & 396.12 & 509.41 & - & - & - & 6849.430 & 1141.572 \\
\hline SP 03 & Uca sp 03 & 3148.100 & - & - & - & 1634.70 & 460.6 & 1516.3 & - & - & - & 6759.700 & 1689.925 \\
\hline SP 04 & Uca sp 04 & 1003.100 & 870.260 & 870.260 & 442.10 & & 877.08 & 331.57 & - & - & - & 4394.370 & 732.395 \\
\hline SP 05 & $\begin{array}{l}\text { Uca sp 05/ Uca crassipes (Adams \& White, } \\
1848 \text { ) }\end{array}$ & 764.080 & 454.8 & 454.8 & - & 189.47 & - & 837.66 & - & - & - & 2700.810 & 540.162 \\
\hline SP 06 & Uca spp 06 & 741.740 & 621.810 & 621.810 & - & 1061.00 & 350.11 & 8652.2 & - & - & - & 12048.670 & 2008.112 \\
\hline SP 07 & Uca sp 07 & 982.640 & 1528.200 & 1528.200 & - & 1255.80 & 279.22 & 1243.6 & - & - & - & 6817.660 & 1136.277 \\
\hline SP 08 & Parasesarma sp 01 & 1965.200 & 566.03 & 566.03 & - & - & - & 2019.8 & 721.92 & - & - & 5838.980 & 1167.796 \\
\hline SP 09 & Uca sp 08 & 519.280 & - & - & - & - & - & - & - & - & - & 519.280 & 519.280 \\
\hline SP 10 & Uca sp 09 & 945.970 & - & - & - & - & - & 339.59 & - & - & - & 1285.560 & 642.780 \\
\hline SP 11 & Uca sp 10 & 966.140 & 6674.900 & 6674.900 & - & & 564.69 & 5150.7 & - & - & - & 20031.330 & 4006.266 \\
\hline SP 12 & $\begin{array}{l}\text { Uca sp 11/U. perplexa (H. Milne Edwards, } \\
\text { 1852) }\end{array}$ & 307.080 & - & - & - & - & - & 1209.8 & - & - & - & 1516.880 & 758.440 \\
\hline SP 13 & Parasesarma sp 02 & 310.990 & 716.240 & 716.240 & 997.44 & 1295.00 & 3100 & - & - & - & - & 7135.910 & 1189.318 \\
\hline Sp 14 & Uca sp 12 & 14.214 & - & 473.91 & 994.72 & 552.74 & 636.77 & 1315.5 & - & - & - & 3987.854 & 664.642 \\
\hline Sp 15 & Parasesarma sp 03 & 236.880 & - & - & 977.01 & - & - & 1315.5 & - & - & - & 2529.390 & 843.130 \\
\hline SP 16 & Parasesarma sp 04 & 403.150 & - & - & - & - & 402 & 831.95 & - & - & - & 1637.100 & 545.700 \\
\hline SP 17 & Uca sp 13 & 331.640 & - & - & - & - & & 1989.4 & - & - & - & 2321.040 & 1160.520 \\
\hline SP 18 & Uca sp 14 & 105.700 & - & 464.08 & 1160.68 & - & - & - & - & - & - & 1730.460 & 576.820 \\
\hline SP 19 & Uca sp 15 & 169.700 & - & - & - & - & - & 397.96 & - & - & - & 567.660 & 283.830 \\
\hline SP 20 & Parasesarma sp 05 & 10225.000 & - & - & 5813.00 & 3836.80 & 682.37 & - & 4421.9 & - & - & 24979.070 & 4995.814 \\
\hline SP 21 & Uca sp 16 & 6367.200 & - & - & - & - & - & - & - & - & - & 6367.200 & 6367.200 \\
\hline SP 22 & Uca sp 17/ Uca tetragonon (Herbst, 1790) & 834.400 & - & - & - & - & - & 1700.7 & - & - & - & 2535.100 & 1267.550 \\
\hline
\end{tabular}




\begin{tabular}{|c|c|c|c|c|c|c|c|c|c|c|c|c|c|}
\hline SP 23 & Parasesarma sp 06 & 493.350 & 554.140 & 554.140 & - & - & - & - & - & - & - & 1601.630 & 533.877 \\
\hline SP 24 & $\begin{array}{l}\text { Uca sp 18/ Uca dussumieri (H. Milne } \\
\text { Edwards, 1852) }\end{array}$ & 518.200 & - & |- & - & |- & 254.7 & 451.4 & - & - - & - & 1224.300 & 408.100 \\
\hline SP 25 & $\begin{array}{l}\text { Uca spp 19/ } \\
\text { U. jocelynae Shih, Naruse \& Ng, } 2010\end{array}$ & 1834.100 & - & |- & - & |- & - & |- & - & |- & - & 1834.100 & 1834.100 \\
\hline Sp 26 & Macrophthalmus sp 01 & 589.770 & - & - & - & - & - & - & - & - & - & 589.770 & 589.770 \\
\hline SP 27 & Uca sp 20 & 360.970 & 240.730 & 240.730 & 361.72 & 1136.80 & 832.34 & 438.52 & - & - & - & 3611.810 & 515.973 \\
\hline SP 28 & Ocypode pallidula (Jacquinot, 1852) & 159.150 & - & - & - & - & - & 497.36 & - & - & - & 656.510 & 328.255 \\
\hline SP 29 & Uca sp 21 & 252.630 & 745.900 & 745.900 & - & - & 1274.9 & - & - & 1390.800 & 723.870 & 5134.000 & 855.667 \\
\hline SP 30 & Parasesarma sp 07 & - & 1956.500 & 1956.500 & - & 1856.40 & 1425.8 & - & 588.39 & 1104.800 & 1177.800 & 10066.190 & 1438.027 \\
\hline SP 31 & Sarmatium cassum (Dana, 1851) & - & 884.19 & 884.19 & - & - & - & - & - & - & - & 1768.380 & 884.190 \\
\hline SP 32 & Parasesarma sp 08 & - & 1243.6 & 1243.6 & 587.95 & 587.95 & 212.25 & - & - & 2343.600 & 1013.600 & 7232.550 & 1033.221 \\
\hline SP 33 & Uca sp 22/ Uca triangularis & - & 514.52 & 514.52 & & 265.26 & 212.25 & 1482.3 & - & - & 663.150 & 3652.000 & 608.667 \\
\hline SP 34 & Epixanthus dentatus (white, 1847) & - & 442.1 & 442.1 & - & - & - & - & - & - & 636.620 & 1520.820 & 506.940 \\
\hline SP 35 & Metopograpsus sp 01 & - & 471.69 & 471.69 & 5305.20 & - & 1720.5 & - & - & - & - & 7969.080 & 1992.270 \\
\hline SP 36 & Uca sp 23 & - & 663.15 & 663.15 & - & - & - & 795.77 & - & - & - & 2122.070 & 707.357 \\
\hline SP 37 & Uca sp 24 & - & 491.32 & 491.32 & - & - & - & - & - & - & 530.520 & 1513.160 & 504.387 \\
\hline SP 38 & Uca sp 25 & - & - & - & 412.53 & - & 1720.5 & - & - & - & - & 2133.030 & 1066.515 \\
\hline SP 39 & $\begin{array}{l}\text { Macrophthalmus sp } 02 \text { (Wada and Sakai, } \\
\text { 1989) }\end{array}$ & - & - & 691.300 & - & - & - & - & - & - & - & 691.300 & 691.300 \\
\hline SP 40 & Ilyoplax sp & - & - & - & - & - & 393.06 & 3227.3 & - & - & - & 3620.360 & 1810.180 \\
\hline SP 41 & Thalamita creanata (Latreille, 1829) & - & - & - & 305.65 & - & - & - & 270.73 & - & - & 576.380 & 288.190 \\
\hline SP 42 & Selatium sp 01 & - & - & - & 2132.000 & - & - & - & - & - & - & 2132.000 & 2132.000 \\
\hline SP 43 & Parasesarma sp 09 & - & - & - & 2105.70 & - & - & - & - & - & - & 2105.700 & 2105.700 \\
\hline SP 44 & Parasesarma sp 10 & - & - & - & 1136.80 & - & - & - & - & - & - & 1136.800 & 1136.800 \\
\hline SP 45 & Uca sp 26 & - & - & - & 230.66 & - & - & - & - & - & - & 230.660 & 230.660 \\
\hline
\end{tabular}




\begin{tabular}{|c|c|c|c|c|c|c|c|c|c|c|c|c|c|}
\hline SP 46 & Uca sp 27 & - & - & - & 884.19 & 9129.00 & 877 & - & - & - & - & 10890.190 & 3630.063 \\
\hline SP 47 & $\begin{array}{l}\text { Metopograpsus sp 02/ } \\
\text { Metopograpsusfrontalis (Miers, 1880) }\end{array}$ & - & - & - & 328.89 & 902.24 & 4727.5 & 203.75 & 509.38 & - & 2356.100 & 9027.860 & 1504.643 \\
\hline SP 48 & Parasesarma sp 11 & - & - & - & - & 994.72 & 601.52 & - & - & - & 486.390 & 2082.630 & 694.210 \\
\hline SP 49 & Perisesarma sp 01 & - & - & - & - & - & 833.89 & - & 227.45 & - & - & 1061.340 & 530.670 \\
\hline SP 50 & Myomenippe sp & - & - & - & - & - & 1344.2 & 795.77 & & - & - & 2139.970 & 1069.985 \\
\hline SP 51 & Perisesarma sp 02 & - & - & - & - & - & - & - & - & 2024.500 & 2725.400 & 4749.900 & 2374.950 \\
\hline SP 52 & Selatium sp 02 & - & - & - & - & - & - & - & - & 627.920 & 328.160 & 956.080 & 478.040 \\
\hline SP 53 & Parasesarma sp 12 & - & - & - & - & - & - & - & - & 331.570 & & 331.570 & 331.570 \\
\hline \multicolumn{2}{|c|}{ AVERAGE } & 1456.013 & 1117.094 & 1042.225 & 1731.734 & 1678.363 & 1050.951 & 1502.887 & 1123.295 & 1303.865 & 1064.161 & - & - \\
\hline \multicolumn{2}{|l|}{ SUM } & 42224.374 & 22341.880 & 23971.170 & 32902.940 & 25175.450 & 26273.770 & 37572.180 & 6739.770 & 7823.190 & 10641.610 & - & - \\
\hline
\end{tabular}

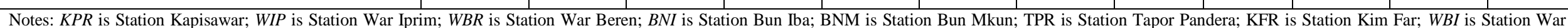
Beki; WOR is Station War Ongkor, WMK is Station War Manak. 


\section{The Associated Crab Species in a Micro-habitat}

The composition of communities is often effected by competition and predation (Primack, 2006). There are many factors may effect to the species composition in a particular habitat. For example, the presence of predator may dramatically reduce the densities of certain prey species and change the composition of a community. Other example, the competition among individuals in a community, indirectly may reduce the density of species and change the composition of species as well.

The population size and interaction of a species may often be controlled by other species that compete with it for the same resources of an ecosystem can support (Primack, 2006). Commonly crabs population have cluster pattern and view of them are random pattern. We have found that several crabs show their ability to be dominant in piece of habitat, and also some different crab species appear to gather in the same micro habitat.

However, this external factor like the habitat variety has significant contribution to the interaction and association among crab species. Due to the habitat variety might provide better condition for more species. Therefore we can describe the relationship among habitat diversity, the number of species, and the level of species interaction and association. These three components have a signicant relationship. The habitat diversity is high than crab diverisity will increase, and than the level of interaction among species will increase as well.

This observation has identified numerous crab species are accupying microhabitats in ten stations (appear in table 21), where 41 species have associated ability and 12 species does not have associated ability. The associated ability means the ability of crab species to share their microhabitat or to live to gather with other different species in a micro habitat. This data shows that not all crab species in a particular mangrove ecosystem, can share their micro-habitat with other crab species. For example, in St. Kapisawar, there are 29 species of crabs, but only 18 species of them can share their habitat with other species. While St. Watiprim, there are 22 species, and only 12 species can share their habitat. Others examples can be seen clearly in table 21. In the other word those species have good ability than other crabs in order to associate with other species in a particular mangrove ecosystem. Uca spp are common species in Gam Bay region, this group species is being associated well than other crabs species. Because, from the total 26 Uca species in Gam Bay Region, 23 Uca spp can be shared in their habitat. 
Table 21. The Numbers of Associated Mangrove Crab Species in Micro-habitat

\begin{tabular}{|c|c|c|c|c|c|c|c|c|c|c|c|}
\hline Code & Species & KPR & WIP & WBR & $\mathrm{BNI}$ & BNM & TPR & KFR & WBI & WOR & WMK \\
\hline SP 01 & Uca sp 01/Uca crassipes (White, 1847) & 18 & 4 & 1 & 5 & 1 & 0 & 0 & 7 & 0 & 0 \\
\hline SP 02 & Uca sp 02 & 5 & 4 & 1 & 0 & 0 & 0 & 0 & 8 & 0 & 0 \\
\hline SP 03 & Uca sp 03 & 15 & 0 & 4 & 0 & 9 & 0 & 0 & 0 & 0 & 0 \\
\hline SP 04 & Uca sp 04 & 2 & 5 & 0 & 0 & 0 & 0 & 0 & 0 & 0 & 0 \\
\hline SP 05 & $\begin{array}{l}\text { Uca sp 05/ Uca crassipes (Adams \& } \\
\text { White, 1848) }\end{array}$ & 2 & 0 & 0 & 0 & 0 & 0 & 0 & 1 & 0 & 0 \\
\hline SP 06 & Uca spp 06 & 3 & 0 & 31 & 0 & 0 & 0 & 0 & 3 & 0 & 0 \\
\hline SP 07 & Uca sp 07 & 0 & 0 & 0 & 14 & 0 & 1 & 0 & 0 & 0 & 0 \\
\hline SP 08 & Parasesarma sp 01 & 0 & 1 & 5 & 0 & 0 & 0 & 2 & 8 & 0 & 0 \\
\hline SP 09 & Uca sp 08 & 8 & 0 & 0 & 0 & 0 & 0 & 0 & 0 & 0 & 0 \\
\hline SP 10 & Uca sp 09 & 0 & 0 & 0 & 0 & 0 & 0 & 0 & 0 & 0 & 0 \\
\hline SP 11 & Uca sp 10 & 12 & 15 & 16 & 0 & 0 & 5 & 0 & 0 & 0 & 0 \\
\hline SP12 & $\begin{array}{l}\text { Uca sp 11/ U. perplexa (H. Milne } \\
\text { Edwards, 1852) }\end{array}$ & 0 & 0 & 3 & 0 & 0 & 0 & 0 & 0 & 0 & 0 \\
\hline SP 13 & Parasesarma sp 02 & 0 & 3 & 0 & 1 & 6 & 0 & 0 & 15 & 0 & 0 \\
\hline SP 14 & Uca sp 12 & 1 & 2 & 2 & 1 & 1 & 0 & 0 & 0 & 0 & 0 \\
\hline SP 15 & Parasesarma sp 03 & 0 & 0 & 2 & 1 & 0 & 0 & 0 & 3 & 0 & 0 \\
\hline SP 16 & Parasesarma sp 04 & 2 & 0 & 0 & 0 & 0 & 0 & 0 & 3 & 0 & 0 \\
\hline SP 17 & Uca sp 13 & 0 & 0 & 0 & 0 & 0 & 0 & 0 & 0 & 0 & 0 \\
\hline SP 18 & Uca sp 14 & 1 & 0 & 0 & 2 & 0 & 0 & 0 & 0 & 0 & 0 \\
\hline SP 19 & Uca sp 15 & 7 & 0 & 0 & 0 & 0 & 0 & 0 & 0 & 0 & 0 \\
\hline SP 20 & Parasesarma sp 05 & 0 & 0 & 0 & 6 & 5 & 0 & 2 & 0 & 0 & 0 \\
\hline SP 21 & Uca sp 16 & 1 & 0 & 0 & 0 & 0 & 0 & 0 & 0 & 0 & 0 \\
\hline SP 22 & $\begin{array}{l}\text { Uca sp 17/ Uca tetragonon (Herbst, } \\
\text { 1790) }\end{array}$ & 3 & 0 & 1 & 0 & 0 & 0 & 0 & 0 & 0 & 0 \\
\hline SP 23 & Parasesarma sp 06 & 2 & 1 & 0 & 0 & 0 & 0 & 0 & 1 & 0 & 0 \\
\hline SP 24 & $\begin{array}{l}\text { Uca sp 18/ Uca dussumieri (H. Milne } \\
\text { Edwards, 1852) }\end{array}$ & 1 & 0 & 0 & 0 & 0 & 0 & 0 & 3 & 0 & 0 \\
\hline SP 25 & $\begin{array}{l}\text { Uca spp } 19 / \\
\text { U. jocelynae Shih, Naruse \& } \mathrm{Ng}, 2010\end{array}$ & 9 & 0 & 0 & 0 & 0 & 0 & 0 & 0 & 0 & 0 \\
\hline SP 26 & Macrophthalmus sp 01 & 1 & 0 & 0 & 0 & 0 & 0 & 0 & 0 & 0 & 0 \\
\hline Sp 27 & Uca sp 20 & 0 & 0 & 0 & 0 & 0 & 4 & 0 & 0 & 0 & 0 \\
\hline Sp 28 & Ocypode pallidula (Jacquinot, 1852) & 0 & 0 & 0 & 0 & 0 & 0 & 0 & 0 & 0 & 0 \\
\hline SP 29 & Uca sp 21 & 0 & 5 & 0 & 0 & 0 & 0 & 0 & 16 & 3 & 0 \\
\hline SP 30 & Parasesarma sp 07 & 0 & 7 & 0 & 0 & 0 & 6 & 5 & 5 & 8 & 11 \\
\hline SP 31 & Sarmatium cassum (Dana, 1851) & 0 & 0 & 0 & 0 & 0 & 0 & 0 & 0 & 8 & 0 \\
\hline SP 32 & Parasesarma sp 08 & 0 & 0 & 0 & 0 & 0 & 0 & 0 & 0 & 0 & 20 \\
\hline SP 33 & Uca sp 22/Uca triangularis & 0 & 0 & 2 & 0 & 0 & 3 & 0 & 9 & 0 & 0 \\
\hline SP 34 & Epixanthus dentatus (white, 1847) & 0 & 0 & 0 & 0 & 0 & 0 & 0 & 0 & 0 & 0 \\
\hline SP 35 & Metopograpsus sp 01 & 0 & 1 & 0 & 0 & 0 & 0 & 0 & 0 & 0 & 0 \\
\hline SP 36 & Uca sp 23 & 0 & 0 & 5 & 1 & 0 & 0 & 0 & 0 & 0 & 0 \\
\hline SP 37 & Uca sp 24 & 0 & 1 & 0 & 0 & 0 & 0 & 0 & 3 & 0 & 0 \\
\hline SP 38 & Uca sp 25 & 0 & 0 & 0 & 3 & 0 & 22 & 0 & 2 & 0 & 0 \\
\hline SP 39 & $\begin{array}{l}\text { Macrophthalmus sp } 02 \text { (Wada and } \\
\text { Sakai, 1989) }\end{array}$ & 0 & 0 & 0 & 0 & 0 & 0 & 0 & 0 & 0 & 0 \\
\hline SP 40 & Ilyoplax sp & 0 & 0 & 2 & 0 & 0 & 2 & 0 & 2 & 0 & 0 \\
\hline SP 41 & Thalamita creanata (Latreille, 1829) & 0 & 0 & 0 & 0 & 0 & 0 & 0 & 0 & 0 & 0 \\
\hline SP 42 & Selatium sp 01 & 0 & 0 & 0 & 0 & 0 & 0 & 0 & 1 & 0 & 0 \\
\hline Sp 43 & Parasesarma sp 09 & 0 & 0 & 0 & 4 & 0 & 0 & 0 & 0 & 0 & 0 \\
\hline SP 44 & Parasesarma sp 10 & 0 & 0 & 0 & 0 & 0 & 0 & 0 & 0 & 0 & 0 \\
\hline SP 45 & Uca sp 26 & 0 & 0 & 0 & 0 & 0 & 0 & 0 & 0 & 0 & 0 \\
\hline SP 46 & Uca sp 27 & 0 & 0 & 0 & 0 & 22 & 0 & 0 & 0 & 0 & 0 \\
\hline SP 47 & $\begin{array}{l}\text { Metopograpsus sp 02/ } \\
\text { Metopograpsusfrontalis (Miers, 1880) }\end{array}$ & 0 & 0 & 0 & 0 & 1 & 1 & 6 & 0 & 21 & 0 \\
\hline SP 48 & Parasesarma sp 11 & 0 & 0 & 0 & 0 & 0 & 7 & 0 & 0 & 8 & 0 \\
\hline SP 49 & Perisesarma sp 01 & 0 & 0 & 0 & 0 & 0 & 5 & 1 & 0 & 0 & 0 \\
\hline SP 50 & Myomenippe sp & 0 & 0 & 0 & 0 & 0 & 0 & 0 & 0 & 0 & 0 \\
\hline SP 51 & Perisesarma sp & 0 & 0 & 0 & 0 & 0 & 0 & 0 & 0 & 20 & 18 \\
\hline SP 52 & Selatium sp 02 & 0 & 0 & 0 & 0 & 0 & 0 & 0 & 0 & 0 & 0 \\
\hline SP 53 & Parasesarma sp 12 & 0 & 0 & 0 & 0 & 0 & 0 & 0 & 0 & 0 & 0 \\
\hline \multicolumn{2}{|c|}{ Total Individual } & 93 & 49 & 75 & 38 & 45 & 56 & 16 & 90 & 68 & 49 \\
\hline & Total Species & 18 & 12 & 13 & 10 & 7 & 10 & 5 & 17 & 6 & 3 \\
\hline
\end{tabular}

Notes: KPR is Station Kapisawar; WIP is Station War Iprim; WBR is Station War Beren; $B N I$ is Station Bun Iba; $B N M$ is

Station Bun Mkun; TPR is Station Tapor Pandera; KFR is Station Kim Far; WBI is Station War Beki; WOR is Station War Ongkor, $W M K$ is Station War Manak. 


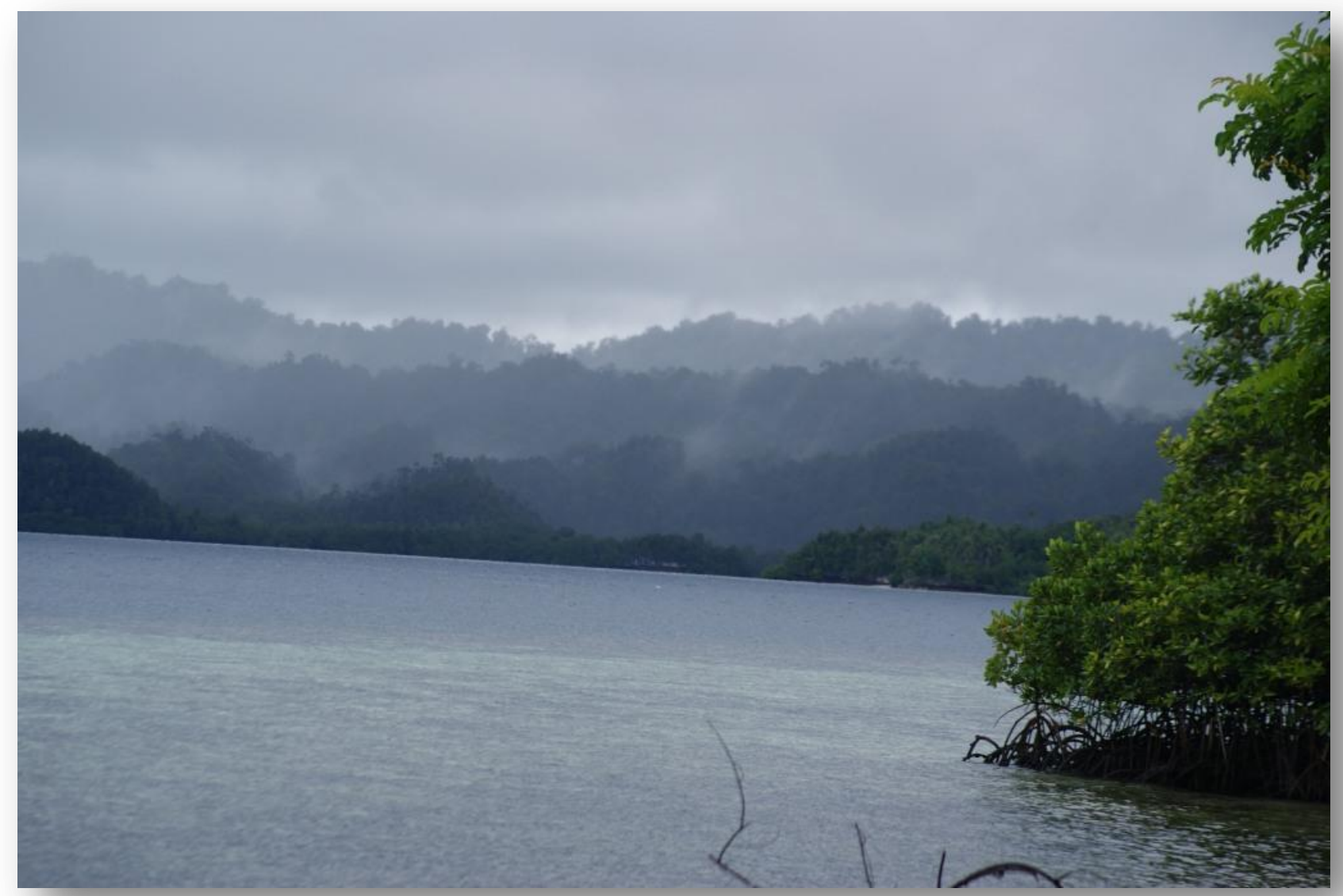

Gam Bay, Raja Ampat 


\section{Chapter V. Disscusion}

\section{A. Mangrove Ecosystem in Gam Bay: The Diversity of Crab Habitat and Disturbances Level}

\section{The Diversity of Crab Habitat and the Cluster of Mangrove Ecosystem in Gam Bay}

The suitable habitats and resources are very important for many organisms (Krebs, 1985; Begon, et al., 1990; Ricklefs, 1990; Brewer, 1994). There are 9 types of crab habitats in Gam bay area, such as: muddy, muddy-sand, muddy-sand-gravels, sandy, sandy-mud, sandy-gravel, flat rocky, the dead wood stemp, and mangrove roots. The types of crab habitat at ten stations are found in table 22. We founded that more various crab habitats are available in the coastlines area than in the river area, cove area, and islands area (appear in Table 22, Figure 10, and Figure 11). Schlacher et al. (2011), states the coastal dunes are structurally more complex than beaches, providing animals with a diversity of microclimates and habitats.

Probably the most reason for the variety of habitats in an area is the largest area may have more type of habitat than smallest area (Begon, et al., 1990). The first possible reason for the habitat diversity in the coastline is those stations are connected with the main island or Gam Island, due to the habitats in that ecosystem are more affected by the mainland characteristic and their fluctuation. For example by sedimentation, the rainwater will bring more mud particles in the mangrove ecosystem during reany season.

Other possible reason is the zonation pattern of the ecosystems in seashore area, for example St. Kapisawar, St. War Iprim, and St. Warberen. We have found, the continue ecosystem are following the coast vegetations ecosystem (consist by shrubs and many different trees), mangroves ecosystem, sea-grass ecosystem, and coral reef ecosystem. However, this type of zonation is uncommon in Gam Bay, only view location has complete zonation like that. The affected of seashore in the variety of crab habitat, for example if a mangrove ecosystem close to the coral reef ecosystem, because of the daily tides and waves fluctuations are bring many sand particle include gravels of corals to the mangrove ecosystem, as the result that mangrove ecosystem will have sandy or gravels as the substrates.

These oceanographic conditions are contributed to the variety of crab habitat as well, such as the low and high tides fluctuation, winds, rainwater and sea current, was carrying many sediment in to the coast line. For example the rains are carryies and 
deposits more mud sediments from the coast vegetation ecosystem than created the muddy substrate. While the sea current and low-high tides fluctuation bring more sand particles from coral reef ecosystem to coast line. A strong wind can break down large threes than became a micro habitat for several crab species.

Geographically islands are isolated from the mainland. These are affected the numbers of crabs habitat and crab itself, for example in St. Bun Iba and St. Bun Mkun Island, both island have few crab habitats (Appear in Table 22), such as sandy and sandymud. These islands are being shelter from the strong waves and current. Commonly waves and currents flucatuation are carrying more sand particles are coming from the sea, however mud particles are coming from the island itself. On the other hand mangrove trees in these islands are not too tall, perhaps that trees are difficult to breakdown by strong wins. Dominanted trees are founded in these islands, such as: Bruguieria gymnorrhiza, B. mucronata, Sonneratia alba, and Rizophora stylosa.,

Table 22. The Variety of Mangrove Crabs Habitat in Gam Bay

\begin{tabular}{|c|c|c|c|c|}
\hline STATIONS & Substrates as crab habitat & Other crab habitat & $\begin{array}{c}\text { Type of } \\
\text { Ecosystem }\end{array}$ & $\begin{array}{c}\text { Number of } \\
\text { Crab Habitats }\end{array}$ \\
\hline St. Kapisawar & $\begin{array}{l}\text { Muddy, Muddy-sand, Muddy-sand- } \\
\text { gravels, Sandy, Sandy-mud }\end{array}$ & $\begin{array}{l}\text { The dead wood stem, } \\
\text { mangrove root }\end{array}$ & Coastlines & 7 \\
\hline St. War Ipirm & $\begin{array}{l}\text { Muddy, Muddy-sand, Muddy-sand- } \\
\text { gravels, Sandy, Sandy-mud }\end{array}$ & $\begin{array}{l}\text { The dead wood stem, } \\
\text { mangrove root }\end{array}$ & Coastlines & 7 \\
\hline St. War Beren & $\begin{array}{l}\text { Sandy, Sandy-gravels, Sandy-mud, } \\
\text { Muddy, Flat rocky }\end{array}$ & mangrove root & Coastlines & 6 \\
\hline St. Bun Iba & $\begin{array}{l}\text { Muddy, Sandy-mud, Sandy, Flat } \\
\text { rocky. }\end{array}$ & mangrove root & Islands & 5 \\
\hline St. Bun Mkun & Sandy, Sandy-mud, Muddy-sand & mangrove root & Islands & 4 \\
\hline St. Tapor Pandera & $\begin{array}{l}\text { Muddy, Muddy-sand, Sandy, } \\
\text { Sandy-mud }\end{array}$ & $\begin{array}{l}\text { The dead wood stem, } \\
\text { mangrove root }\end{array}$ & Rivers & 6 \\
\hline St. Kim Far & Sandy-mud, Gravels-sand & mangrove root & Rivers & 3 \\
\hline St. War Beki & $\begin{array}{l}\text { Muddy, Clay, Clay-muddy, } \\
\text { Muddy-clay, Flat rocky }\end{array}$ & $\begin{array}{l}\text { The dead wood stem, } \\
\text { mangrove root }\end{array}$ & Cove & 6 \\
\hline St. War Ongkor & Muddy & $\begin{array}{l}\text { The dead wood stem, } \\
\text { mangrove root }\end{array}$ & Cove & 3 \\
\hline St. War Manak & Muddy, Clay & $\begin{array}{l}\text { The dead wood stem, } \\
\text { mangrove root }\end{array}$ & Cove & 4 \\
\hline
\end{tabular}

The habitats diversity in Gam Bay is consists by different type of substrates and dead stems of trees and others. The substrate properties have a major impact on mangrove nutrition and its growth. Some of the most important substrates characteristics are saltiness, electrical conductivity, $\mathrm{pH}$, and cation-exchange capacity (Kathiresan \& Bingham, 2001). The most important factor, however, appears to be nutrient concentrations. Mangroves are finely balanced, highly effective nutrient sinks with net imports of dissolved nitrogen, phosphorus, and silicon (Kathiresan \& Bingham, 2001). 


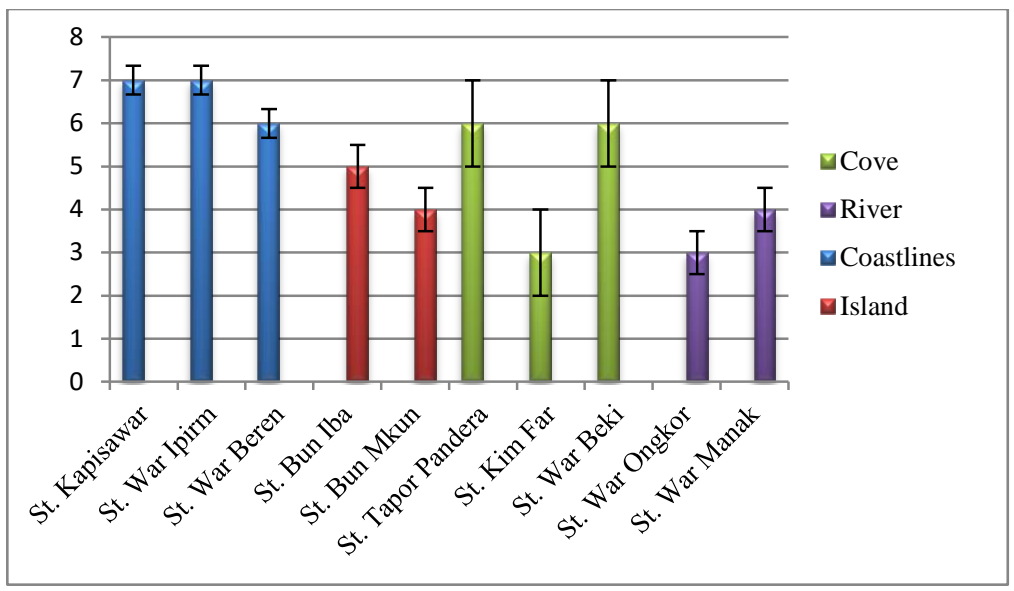

Figure 10. The Variety of Crabs Habitat in Ten Stations

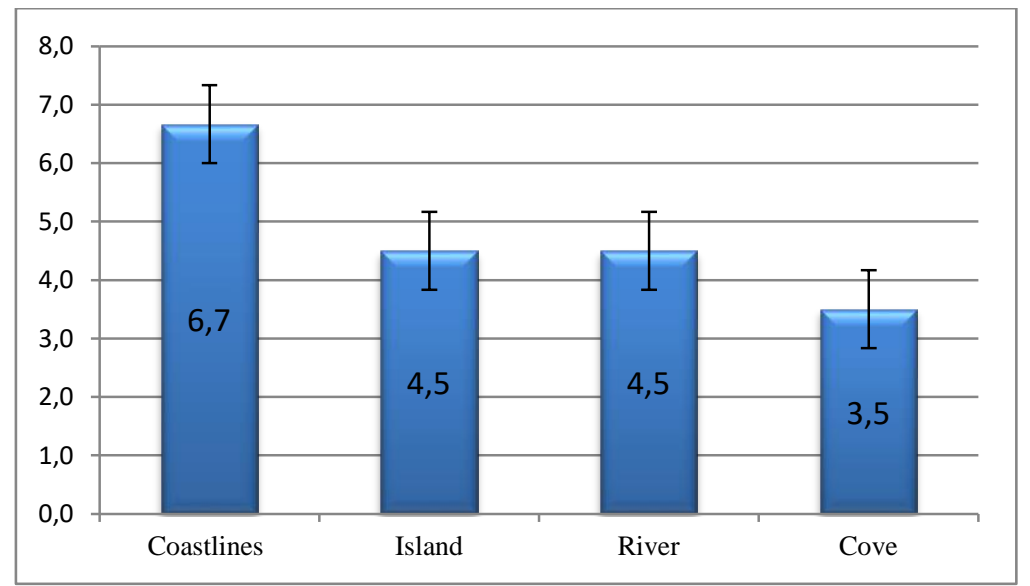

Figure 11. The Comparison between the Type of Mangrove Ecosystem and the Average Numbers of Crabs Habitat

The cluster of mangroves ecosystem in Gam Bay, consists of the coastline mangrove forest ecosystem, islands, rivers, and coves. Each cluster type of mangroves ecosystem have different attributes, such as characteristics (Table 11), species diversity of crab (Table 18) and mangrove diversity (Table 14), density of crab (Table 20) and mangroven density (Table 16), and habitat diversity (Table 22). Based on the cluster of mangroves ecosystem, and then we got the various crabs habitat. For example, the shoreline clusters, on this cluster follows as: muddy, muddy-sand, muddy-sand-gravels, sandy, and sandy-mud, it excludes the dead wood stem and mangrove roots (See table 22, Figure $10, \&$ Figure 11). The habitat diversity in the river clusters of mangrove ecosystem is different, only few crab habitats are available, such as muddy, clay, the dead wood stem, and mangrove roots. These circumstances appear in St. War Manak and St. War Ongkor. 
The diversity of habitats, especially the substrate are very important for the mangroves community as well, most mangrove species do best on muddy soils, i.e. in areas where silt accumulates (Geisen et. al, 2007), and typical for muddy substrates in Gam Bay are the well-developed in St. War Manak and War Ongkor, this substrate are suitable for Rhizophora mucronata and Avicennia marina (Geisen et. al, 2007), in both station we have found two dominant species $R$. mucronata and Bruguiera sexangula (See Table 15). Other example Rhizophora stylosa also do well on sands, and even on coral islands which have a substrate consisting of coral debris, shells and Halimeda (calcareous seaweed) fragments (Geisen et. al, 2007). This species $R$. stylosa are occupying $60 \%$ of ten stations in Gam Bay area, mostly stations are consisting by sands substrates. Gam Island is forming by more entisols and inceptisols soils, and view percent of histosols, vertisols, and mollisols. However, the entisols have mud content are more suitable for the mangrove communities (Marshall, et al. 2007). Within this observation, we did 120 measurement of soil deepness, and then average deepness is about $38.06 \mathrm{~cm}$. This data shows that the soil layers are very thin, due to all soil formation commonly form on flat rocky.

\section{The Disturbances of Mangroves Ecosystem in Gam Bay}

Like other coastal ecosystems however mangroves are threatened by both natural and human-induced stresses (FAO, 2007). Among these stresses are the occurrences of typhoons, barnacle infestation, pollution, commercial harvest for timber and fishery products, and aquaculture developments (Primack, 2006; FAO, 2007). The world's mangroves area are under some form of pressure and have been seriously damaged due to human activities including climate change and others factors (FAO, 2007; Primack, 2006). In the future, sea-level rise could be the biggest threat to mangrove ecosystems (Giri, et al., 2010).

These disturbances factors decrease the global mangrove ecosystem area a lot, as a result lost many mangrove area without recognizing the value of ecological, biological, economical, and more. In fact, we have been faced an alarming 20 percent or 3.6 million hectares of mangroves have been lost since 1980 (FAO, 2007). About 185.000 ha were lost every year in the 1980s, this figure dropped to some 118.500 ha per year in the 1990 s and to 102.000 ha per year (-0.66 percent) during the 2000-2005 period (FAO, 2007). The total mangroves area in Raja Ampat are about 27,180 ha (Appear in Table 23) or 0.16 percent of the total mangrove in the world. Regarding to the FAO estimation 
mangroves area are dropped -.0.66 percent per year indicated the mangroves area in Raja Ampat are decrease approximately 179.33 ha per year (this is an estimation).

Table 23. Mangrove area in Raja Ampat and Others

\begin{tabular}{|l|l|r|l|}
\hline Mangrove Area in & Country & Area (ha) & Sources \\
\hline The World & 112 & $17,075,600$. & FAO, 2007 \\
\hline The Southeast Asia & 11 & $6,800,000$. & Geisen et al, 2007 \\
\hline Indonesia & 1 & $2,930,000$. & FAO, 2003 \\
\hline Papua & - & $1,622,000$. & Noor et al, 2006 \\
\hline Raja Ampat & - & $27,180$. & CII, 2011 \\
\hline
\end{tabular}

Who is the main actor for these worse circumstances? To answer this question we need a fundamental explanation. Over half of the human populations are live in shoreline and coastal area (Turner, et al., 1996) includes on mangrove ecosystem (Macintosh, et $a l ., 2002)$. It's very common that people are using the natural resources for their daily needs. While, the mangrove forest ecosystems are fulfilling numerous of important functions, benefits, and uses for people (Kathiresan \& Bingham, 2001; FAO, 2007; Geisen, et al., 2007). As the consequences people are exploring more mangrove resources without any conservation approach. However, people needs and pressures might be occurred in the same times (Turner et al., 1996).

There 5 villages are nearby Gam Bay area, than the total human population is about 1.615 and density 9, 52/ $\mathrm{km}^{2}$ (BAPPEDA Kabupaten Raja Ampat, 2010). The human population cause more negative influences to the nature, in many areas of the world, particular on island and in locations where human population is high, most of the origin habitat has been destroyed (Primack, 2006). Therefore some scientists have argued strongly that controlling the size of the human population is the key to protect biological diversity (Primack, 2006). Although Gam Bay region does not have high population and density, but the disturbances has been occur (Appear in Table 9 and Figure 12).

In line with the explanantion before that Gam Island is forming by more entisols and inceptisols soils, and view percent of histosols, vertisols, and mollisols. However, the substrates deepness is also important for mangrove ecosystem itself, but geological factors are affected to the survivel of mangrove ecosystem too. Base on the geological characteristic of Gam Bay area, the soil formation are formed on the flat rocky, and the average soil deepness is about $38.06 \mathrm{~cm}$, it is very thin. If the level of disturbances is growing higher, than mangroves ecosystem be degraded more, it means that ecosystem will take longest times to be recovered, because the substrate characteristic especially soil 
deepness is very thin, as consequences the mangrove threes will easier to breakdown. Even so, the disturbance is reduced; the altered soil conditions and limited natural dispersal mean that natural recovery can be very slow.

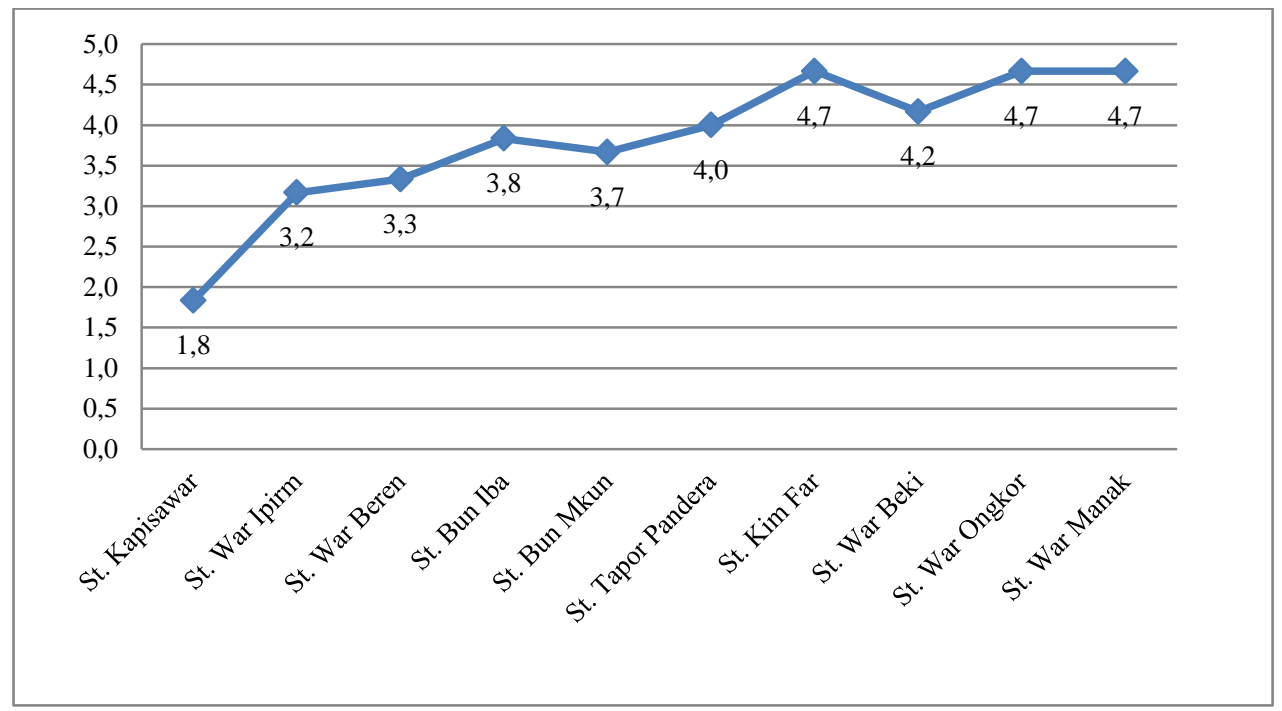

Figure 12. The Level of Disturbances at Ten Stations in Gam Bay Area Note: Where the mean value is the average of all rank from the whole variables, $\leq 1$ is highest disturbances, $>1 \leq 2$ high disturbances, $>2 \leq 3$ is moderate, and $>4 \leq 5$ is no disturbances.

\section{The Disturbances Factors in Gam Bay: the Remoteness as the Indirect Factor of Disturbances}

The mangrove ecosystems in Gam Bay area have been disturbing by several factors, such as: rubbish availability, logging, and transportation activities, harvesting or cutting trees activities for construction materials purpose, and traditional gardening, and then the distances from the village to the mangrove ecosystem as an indirect factor. For all factors are based on human activities. Many scientists have proved that human population and density are the major factors on habitat and ecosystem degradation (Primack, 2006). Within this part we want to explain that there is one indirect factor contributes to the level disturbances and degradation of mangrove forest ecosystem.

In addition, if the disturbances are high in a station nearby the villages, and then the levels of disturbances are increase followed the distances expansion, where St. Kapisawar has high disturbances, while other stations have low to no status of disturbances (See in Table 9 and Figure 12). The possible assumption is the distances from human population to the mangrove ecosystem have significant relationship to the level of disturbances. The distances also will affect to the accessibility and human intervention on mangrove ecosystem. If a mangrove ecosystem is very close to the village, it cause peoples will invest low cost and gain more benefit from resources. in 
other side if the distances of an ecosystem is too far or more remote, people will invest more cost and gain less benefit. As usual every citizen will look for the easy way, close distance, lowest cost, and gain more. That is why; many coastal ecosystems have lost their integrity and the crab habitat being degradation a lot, especially mangrove ecosystem in the coastal area.

Table 24. The Relationship of Disturbances Factors

\begin{tabular}{|l|l|l|l|l|l|l|}
\hline \multicolumn{1}{|c|}{ Comparison } & df & $\alpha$ & $\begin{array}{c}\mathrm{t}- \\
\text { Value }\end{array}$ & $\begin{array}{c}\mathrm{t}- \\
\text { Table }\end{array}$ & $\mathrm{R}^{2}$ & $\begin{array}{l}\text { The } \\
\text { Regression } \\
\text { status }\end{array}$ \\
\hline $\begin{array}{l}\text { The Relationship among the distances from } \\
\text { the station to village and the availability of } \\
\text { Rubbish }\end{array}$ & 9 & 0.0005 & 4.184 & 4.781 & 0.788 & Significant \\
\hline $\begin{array}{l}\text { The Relationship among the distances from } \\
\text { the station to village and harvesting for the } \\
\text { construction material uses }\end{array}$ & 9 & 0.05 & 3.88 & 1.833 & 0.247 & $\begin{array}{l}\text { Less } \\
\text { significant }\end{array}$ \\
\hline $\begin{array}{l}\text { The Relationship among the distances from } \\
\text { the station to village and the availability of } \\
\text { traditional garden }\end{array}$ & 9 & 0.0005 & 2.109 & 4.781 & 0.736 & Significant \\
\hline $\begin{array}{l}\text { The Relationship among the distances from } \\
\text { the station to village and the transportation } \\
\text { activities }\end{array}$ & 9 & 0.0005 & 1.819 & 4.781 & 0.744 & Significant \\
\hline $\begin{array}{l}\text { The Relationship among the distances from } \\
\text { the station to village and logging activities }\end{array}$ & 9 & 0.05 & 6.660 & 1.833 & 0.360 & $\begin{array}{l}\text { Less } \\
\text { significant }\end{array}$ \\
\hline
\end{tabular}

Notes: $t$ statistic > t table: not significant, $\mathrm{t}$ statistic < t table: significant

The comparison between $t$ values and t table, and the comparison determination $\left(\mathrm{R}^{2}\right)$ has been showing that there were no significant relationship among the distances and logging activities, the distances and harvesting mangroves woods for construction material. We are able to accept this because the local people usually look for better quality of mangrove woods. They often travelling to remote mangroves area and do harvesting mangrove trees, because in remote area there are many tallest mangroves trees, especially in St. War Manak, St. War Onkor, St. War Beki, and St. Kim Far. On the other hand, if the mangrove areas are nearby of the village, the local people often harvest mangroves to build their traditional garden attributes and other housing materials. While the logging activities does not often occurr in this Gam Bay area, mainly logging activities take place around 5 to 10 years ago, in the present there are no logging activities has been occur. But we are able to found the marks of logging activities in place nearby the village such as: St. Sawingrai, and then an area is away from the village such as: St. War Beki.

The three comparisons above have significant relationship, such as: the relationship among the distances from mangrove ecosystem area to villages and the 
availability of rubbish, and traditional garden, and the transportation activities (Table 24 and Figure 13). The rubbish availability, it also might influences by the sea current and waves. Both current and waves can carry garbage in to the mangrove ecosystem area, as we mention before that the sea current are periodically strong in this area. Its mean the mangrove area along the coastline and outlet probably will have more polluted than in the rivers system and coves, due the position of this area are surrounding by 10 villages, includes 5 villages from Manswar Island and Arborek Island such as, Yenbuba, Yenbekwan, Sawandarek, Kurkapa, and Arborek (BAPPEDA Kab. Raja Ampat, 2010). We have found a lot of rubbishes in stations along the coast line, such as St Kapisawar, St. War Beren, St. Bun Iba, and St. Bun Mkun. Then other stations in the coves and river system have no garbage, such as St. Tapor Pandera, St. Kim Far, St. Warbeki, St. War Ongkor and St. War Manak.

Traditional gardens are often very close the mangrove ecosystem. Geologically, the characteristic of the main land in Gam Bay area consist of flat surfaces, slopes, rocky hills, and hills. In spite of that the flat surfaces only small portions of the whole area and the rest area have slopes contour. As the consequences people use all flat surfaces of Gam island area for gardening activities. Therefore, many flat lands area along the coastline and even small islands in Gam Bay area has been used for long times. We have found only three locations do not have traditional garden in the land nearby the mangrove ecosystem, such as: St. Kim Far, St. War Ongkor, and St. War Manak. For the transportation activities are often followed by the main activities of the local people, for example harvesting the mangrove tree, fisherman, and so on. Hence this factor has more significant relationship with the distances (See in Figure 13).

However, by using the comparison between $t$ values and $t$ table, and the comparison determination $\left(\mathrm{R}^{2}\right)$ on the simple linear regression has proved, that three factors have significant relationship (Appear in Table 24 and Figure 13), and two factors have less significant relationship with the distances. This result is comparable with table 25 , which is the improvement of the distances level, where $x=1$, the result states, all variables response to the distances expansion, it means the level of disturbances decrease, because the increasing of the values of $y$ indicated the rank of disturbances decrease, while the lowest rank state the highest disturbances and the higher rank states the lowest disturbances. 


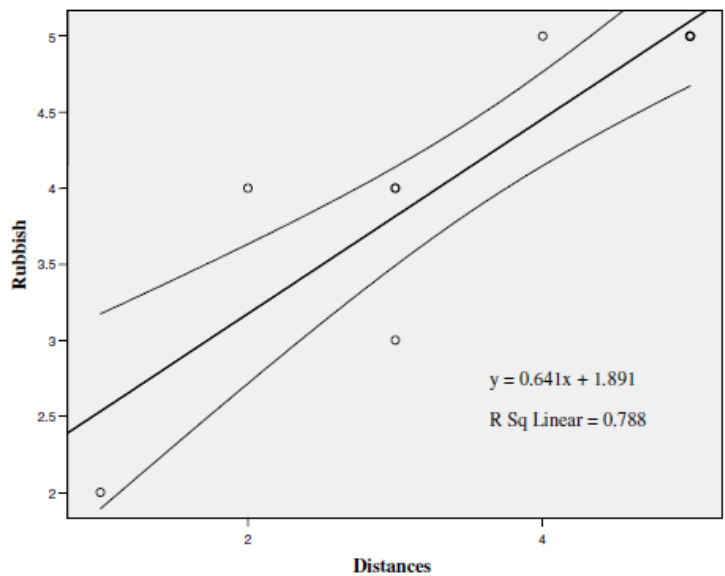

$a$
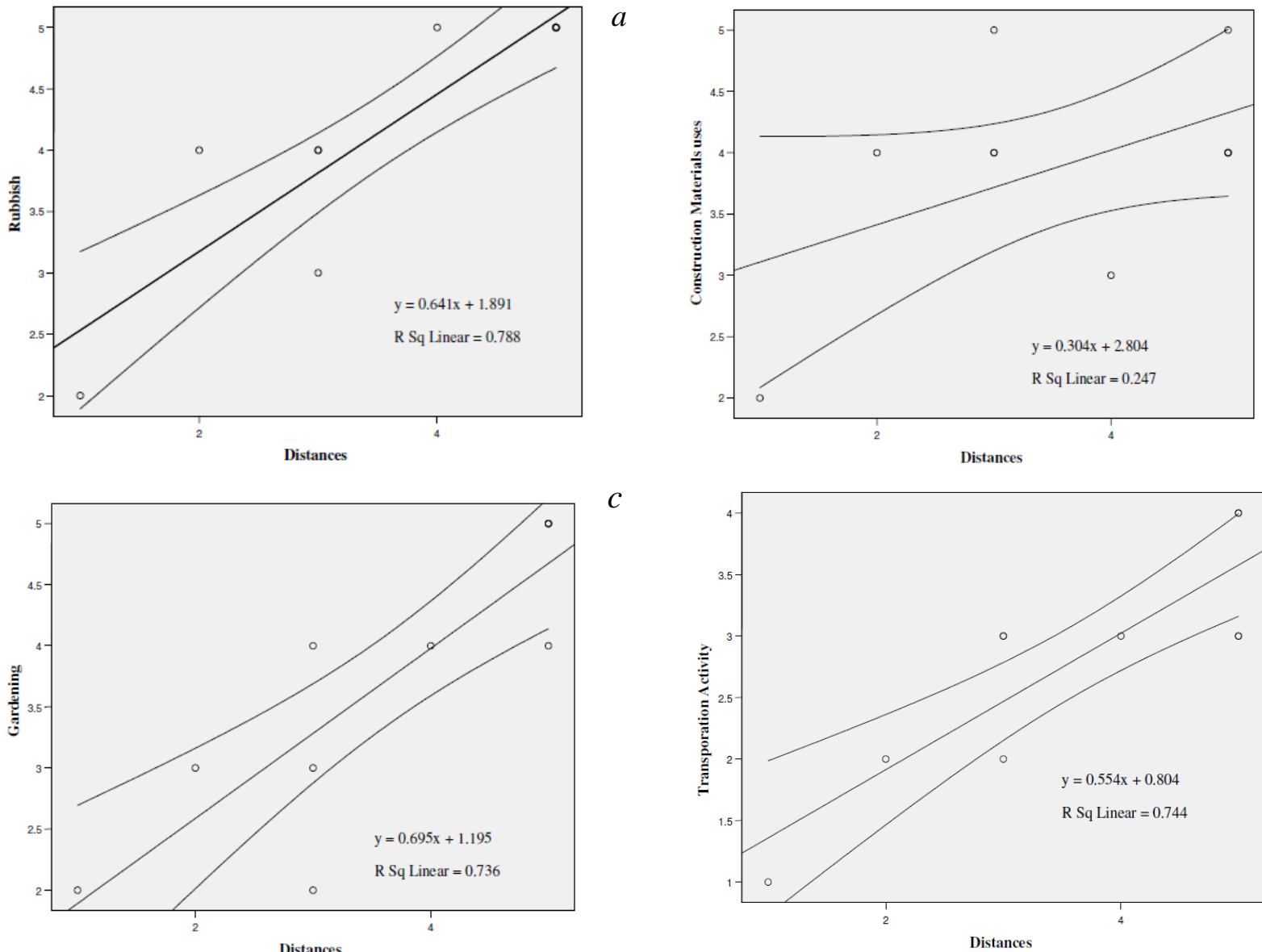

$c$
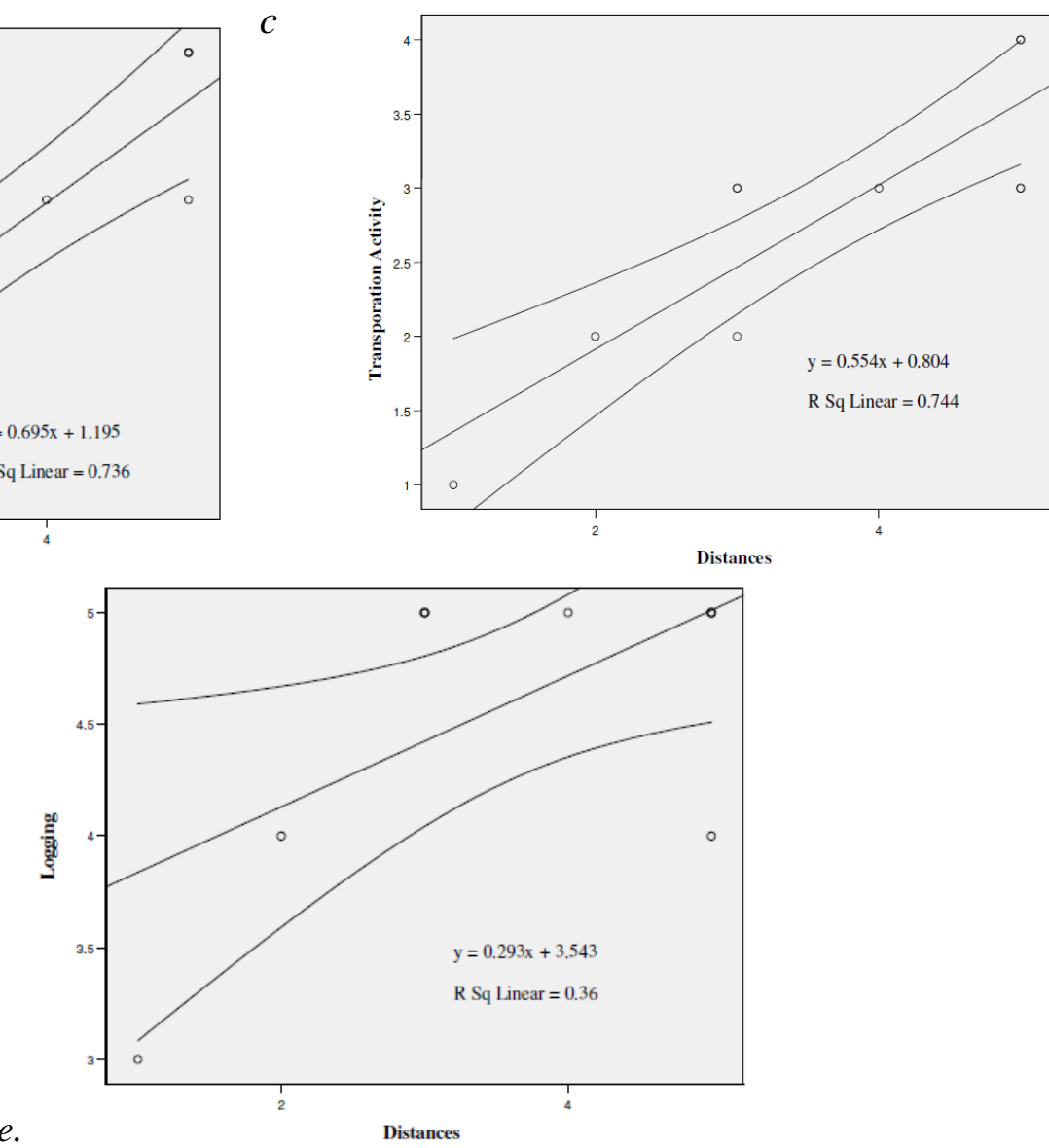

Figure 13. The Relationship among the Distances and Disturbances Factors: Rubbish, Harvesting for the Construction Material Uses, Traditional Garden, Transportation Activity, and Logging Activity

Note: $x$ is distance from a village to a mangrove ecosystem. $\mathrm{y}$ is a disturbance factor, $a$. relationship between distances and rubbish, $b$. relationship between distances and harvesting for construction material, $c$. relationship between distances and traditional garden, $d$. relationship between distances and transportation activity, $e$. relationship between distances and logging activity. 
Table 25. The Relationship among Disturbances Factors, if $x=1$

\begin{tabular}{|l|l|l|l|l|l|}
\hline Comparison & $\mathrm{A}$ & $\mathrm{B}$ & $\mathrm{x}$ & $\mathrm{y}$ & Explanation \\
\hline $\begin{array}{l}\text { The Relationship among the distances from the } \\
\text { station to village and the availability of Rubbish }\end{array}$ & 1.891 & 0.641 & 1 & 2.5 & $y$ value increase \\
\hline $\begin{array}{l}\text { The Relationship among the distances from the } \\
\text { station to village and harvesting for the construction } \\
\text { material uses }\end{array}$ & 2.804 & 0.304 & 1 & 3.1 & $y$ value increase \\
\hline $\begin{array}{l}\text { The Relationship among the distances from the } \\
\text { station to village and the availability of traditional } \\
\text { garden }\end{array}$ & 1.195 & 0.695 & 1 & 1.9 & $y$ value increase \\
\hline $\begin{array}{l}\text { The Relationship among the distances from the } \\
\text { station to village and the transportation activities }\end{array}$ & 0.804 & 0.554 & 1 & 1.4 & $y$ value increase \\
\hline $\begin{array}{l}\text { The Relationship among the distances from the } \\
\text { station to village and logging activities }\end{array}$ & 3.543 & 0.293 & 1 & 3.8 & $y$ value increase \\
\hline
\end{tabular}

Note: increasing the $\mathrm{x}$ values or the distances affected to decrease level of disturbances.

The other consideration is the relationship is not too strong, due to the numbers of factors we use are not big enough to draw the conclusion. But, the figure 14 found that the levels of disturbances are following the distances. These results can be representing the current circumstances, where those factors have considerable relations with the distances as the indirect factor causes disturbances on mangrove ecosystem. In addition this explanation is very helpful because we want to use this information as the additional data to investigate the mangrove crabs diversity as the indicator of ecological status of mangrove ecosystem. On the other side this information can be used as the basic information for the future research about the relationship between remoteness and the ecological status of mangrove ecosystem area. In line with Begon and friends (1990), the remoteness its can simply refer to the degree of physical isolation and also a single island.

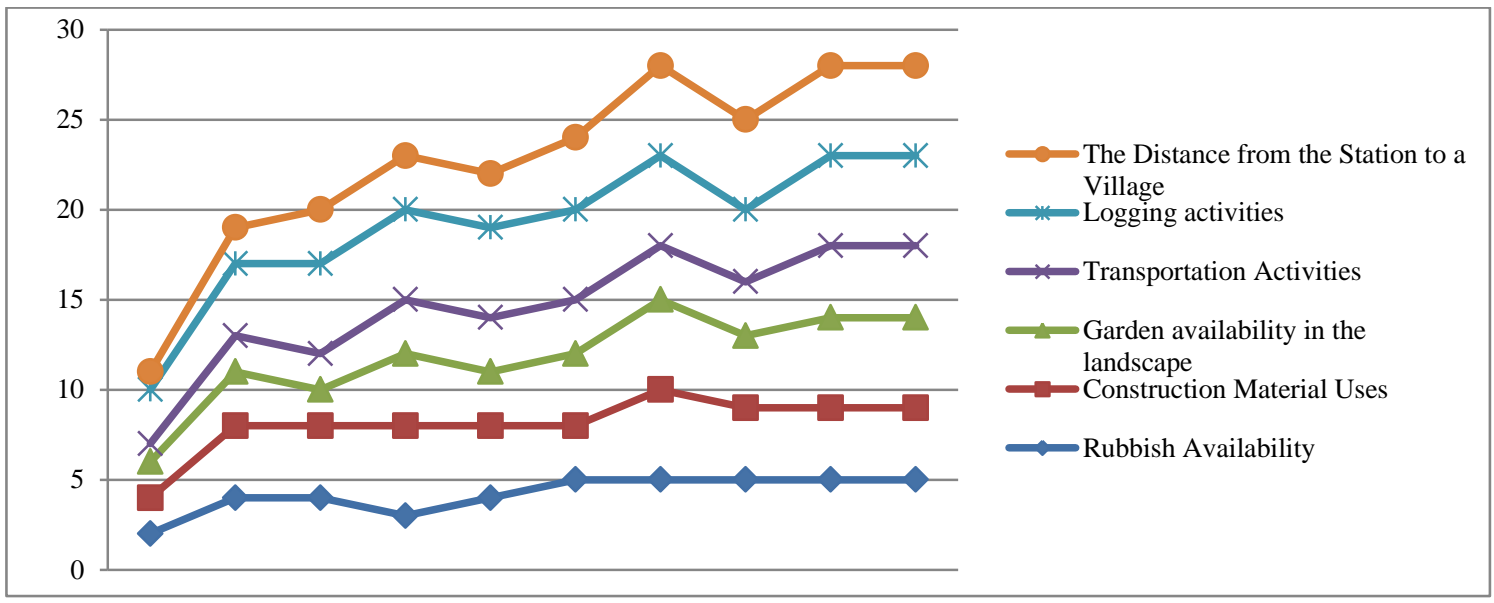

Figure 14. Distances as Indirect Disturbance Factor significantly affected Others Disturbances Factors

Note: All disturbances factors are increase following the distances spread out, each point is represented a station. 


\section{B. The Community Ecological Association among Mangrove Crabs and Mangrove Trees in Gam Bay}

Every single organism in an ecosystem is connected eachothers (Stilling, 1992; Brewer, 1994). Interaction of an organism with the environment is fundamental need for survival and the main functions of the ecosystem. Equally with mangrove crabs, they are connected one an others. Ecologically, mangrove crabs have a strong relationship with the mangrove ecosystem (Kathiresan \& Bingham, 2001). The relationship between mangrove ecosystem and mangrove crabs describe how they are connected. In other words, mangrove ecosystems have gain benefit through the existence of mangrove crabs, than mangrove crabs receive many advantages as well from the ecosystem. This is positive relationship or mutualism relationship between mangroves ecosystem and mangrove crabs.

We categorize two types of association between mangroves ecosystem and mangrove crabs. Firstly the ecological relationship is the affiliation between mangrove crabs as the organism and mangroves forest as the ecosystem. Secondly, the biological interaction is the effects of crabs' community on mangroves community, then the effects of mangroves community toward the mangrove crabs.

In term of the ecological relationship, there are six types of relationship; three of them, such as predation, mutualism, and commensalism. In the case of predation, crab species are categorized as the plant predation, their consuming big amount of mangrove leaf s and propagules (Brown, 1992; Kathiresan \& Bingham, 2001; Gillikin \& Schubart, 2004; Soundarapandian, et al., 2008). Other example for the mutualism and commensalism is crab species usually use mangroves as their microhabitat, while mangrove gets advantage from the recycle nutrients. Mostly crabs family Sesarmidae is plant predation or herbivore, we have indentifying 17 species are inhabited in mangrove ecosystem in Gam Bay area (Table 19). Then among 53 species of mangrove crabs only two migratory species Thalamita creanata (Latreille, 1829) and Myomenippe sp. Its means the majority of crab community are performing the mutualism and commensalism relationship with the mangrove ecosystem.

In term of biological interaction, there is one type of interaction is symbiosis. For example, the individual mangrove tree has provided shelter, microhabitat, and food for the crabs. Probably all mangrove crabs species in Gam Bay area gain the same benefit from the mangroves ecosystem, in this case we want to suggest three climbing crabs as the most dependent species of symbiosis interaction, such as: Selatium sp 01, 
Metopograpsus frontalis (Miers, 1880), and Selatium sp 02. According to Fartini and friends (2005), has give emphasis to the tree-climbing crabs, where these crabs have been showing different degrees of dependence on arboreal life. The suitable assumption is those three climbing crabs may not live without the mangrove ecosystem.

To observe the ecological relationship between mangrove crabs community and mangrove trees community in Gam Bay, we selected three main variables, such as diversity, richness, and density from both communities. After that we investigating their relationship one another. Back to the basic question of this study: whether mangroves ecosystems are affected the mangrove crabs? In order to answer this question, we need to describe the community ecological relationship; base on Odum (1971) this study is called synecology or the study of groups of organisms which are associated together as a unit. Overall will be describing below:

\section{The Association between Mangroves Diversity and the Mangrove Crabs}

\section{Community: Diversity, Richness, and Density}

Four variables has used on this calculation, such: mangroves diversity, mangrove crabs diversity, mangrove crabs richness, mangrove crabs density. Whereas, the diversity of mangroves community is the independent variable and mangrove crab community are the dependent variables. Firstly we use the values of coefficient correlation or $R^{2}$ (Appear in Table 26 and Figure 16). Second, we use the simple linear regression equation (Appear in Table 27 and 28).

Table 26. The Relationship among the Mangrove Diversity and Crabs Community: Diversity, Richness, and Density

\begin{tabular}{|l|l|l|l|}
\hline Comparison & Index & $\mathrm{R}^{2}$ & Correlation \\
\hline \multirow{2}{*}{$\begin{array}{l}\text { The Relationship among mangroves } \\
\text { diversity and mangrove crabs diversity }\end{array}$} & Shannon-Wiener & 0.394 & Less significant \\
\cline { 2 - 4 } & Simpson & 0.19 & Less significant \\
\hline \multirow{2}{*}{$\begin{array}{l}\text { The Relationship among mangroves } \\
\text { diversity and mangrove crabs richness }\end{array}$} & Shannon-Wiener & 0.409 & Less significant \\
\cline { 2 - 4 } & Simpson & 0.297 & Less significant \\
\hline \multirow{2}{*}{$\begin{array}{l}\text { The Relationship among mangroves } \\
\text { diversity and mangrove crabs density }\end{array}$} & Shannon-Wiener & 0.284 & Less significant \\
\cline { 2 - 4 } & Simpson & 0.215 & Less significant \\
\hline
\end{tabular}

The coefficient correlations $\left(\mathrm{R}^{2}\right)$ state all variables have less significant relationship or in other words the influences of mangrove diversity to crabs diversity is weak (Appear in Table 26 and Figure 17). According to Johnson \& Bhattacharyya 
(1996), the high correlation does not necessarily imply a causal relation, but how to describe the relation of the response $y$ to the input variable $x$. In order to describe how the mangrove diversity may affect on crabs community, we will compare the value of $\mathrm{R}^{2}$ and the linear regression calculations. The linear regression equation shows the mangroves diversity positively increase the ecology community of mangrove crabs, it means both variables have a relationship. If we increase the $x$ value (the diversity value of mangroves) about 0.1 , the diversity value, richness, and density of mangroves crabs will increase as well (Appear in Table 27). Although we decrease the $\mathrm{x}$ value became -0.1 , it does not change the prediction value a lot (See in Table 28). The same result appear in table $14,16,18$, and 20 , where the diversity values, species richness, and density values of both community in ten stations have confirmed the result of regression analysis, especially in St. Kim Far, St. War Beki, St. War Ongkor, and St. War Manak. It may indicate the community ecology of mangroves and crabs are connected one to another (Brewer, 1994). According to Brewer (1994), in the ecosystem, community and habitat are bound together by action and reaction.

Table 27. The Relationship among Mangrove Diversity and Mangrove Crabs: if $\mathbf{x}=\mathbf{0 . 1}$

\begin{tabular}{|l|l|l|l|l|l|l|}
\hline Comparison & Index & $\mathrm{A}$ & $\mathrm{b}$ & $\mathrm{x}$ & $\mathrm{y}$ & Explanation \\
\hline \multirow{2}{*}{$\begin{array}{l}\text { The Relationship among } \\
\text { mangroves diversity and } \\
\text { mangrove crabs diversity }\end{array}$} & $\begin{array}{l}\text { Shannon- } \\
\text { Wiener }\end{array}$ & 1.785 & 0.593 & 0.1 & 1.844 & $\begin{array}{l}y \text { value } \\
\text { increase }\end{array}$ \\
\cline { 2 - 8 } & Simpson & 0.651 & 0.244 & 0.1 & 0.67 & $\begin{array}{l}y \text { value } \\
\text { increase }\end{array}$ \\
\hline \multirow{2}{*}{$\begin{array}{l}\text { The Relationship among } \\
\text { mangroves diversity and } \\
\text { mangrove crabs richness }\end{array}$} & $\begin{array}{l}\text { Shannon- } \\
\text { Wiener }\end{array}$ & 0.703 & 1.103 & 0.1 & 0.813 & $\begin{array}{l}y \text { value } \\
\text { increase }\end{array}$ \\
\cline { 2 - 8 } & Simpson & 0.058 & 4.413 & 0.1 & 0.499 & $\begin{array}{l}y \text { value } \\
\text { increase }\end{array}$ \\
\hline \multirow{2}{*}{$\begin{array}{l}\text { The Relationship among } \\
\text { mangroves diversity and } \\
\text { mangrove crabs density }\end{array}$} & $\begin{array}{l}\text { Shannon- } \\
\text { Wiener }\end{array}$ & 5667.884 & 8462.365 & 0.1 & 6514.121 & $\begin{array}{l}y \text { value } \\
\text { increase }\end{array}$ \\
\cline { 2 - 8 } & Simpson & 231.302 & 34586.234 & 0.1 & 3689.925 & $\begin{array}{l}y \text { value } \\
\text { increase }\end{array}$ \\
\hline
\end{tabular}

The same situations are showed in the figure 18, even though the relationship between the mangroves diversity and crabs diversity has weak correlation. But, the result of linear regression equation calculation show the numbers of crab density are increase a lot, if the $\mathrm{x}$ value is 0.1 (Appear in Table 27). Even though we decrease the $\mathrm{x}$ value became -1.0 (Appear in Table 28), then we get the comparison of the result. However, if we compare the Shannon-Wiener and the Simpon index, the results still the same on 
mangroves diversity and two crab community variables (Crab diversity and richness). However, the result for the relationship among mangroves diversity and crab density show unpredicted value, where $y$ value decrease a lot, we will discuss about this issue latter.

Table 28. The Relationship among Mangrove Diversity and Mangrove Crabs: Predicted Value of Mangrove Crabs Community, if $\mathrm{x}=\mathbf{- 0 . 1}$

\begin{tabular}{|c|c|c|c|c|c|c|}
\hline Comparison & Index & $\mathrm{A}$ & $\mathrm{b}$ & $\mathrm{x}$ & $\mathrm{y}$ & Explanation \\
\hline \multirow{2}{*}{$\begin{array}{l}\text { The Relationship among } \\
\text { mangroves diversity and } \\
\text { mangrove crabs diversity }\end{array}$} & $\begin{array}{l}\text { Shannon- } \\
\text { Wiener }\end{array}$ & 1.785 & 0.593 & -0.1 & 1.726 & $\begin{array}{l}y \text { value } \\
\text { increase }\end{array}$ \\
\hline & Simpson & 0.651 & 0.244 & -0.1 & 0.627 & $\begin{array}{l}y \text { value } \\
\text { increase }\end{array}$ \\
\hline \multirow{2}{*}{$\begin{array}{l}\text { The Relationship among } \\
\text { mangroves diversity and } \\
\text { mangrove crabs richness }\end{array}$} & $\begin{array}{l}\text { Shannon- } \\
\text { Wiener }\end{array}$ & 0.703 & 1.103 & -0.1 & 0.593 & $\begin{array}{l}y \text { value } \\
\text { increase }\end{array}$ \\
\hline & Simpson & 0.058 & 4.413 & -0.1 & -0.383 & $\begin{array}{l}y \text { value } \\
\text { increase }\end{array}$ \\
\hline \multirow{2}{*}{$\begin{array}{l}\text { The Relationship among } \\
\text { mangroves diversity and } \\
\text { mangrove crabs density }\end{array}$} & $\begin{array}{l}\text { Shannon- } \\
\text { Wiener }\end{array}$ & 5667.884 & 8462.365 & -0.1 & 4821.648 & $\begin{array}{l}y \text { value } \\
\text { increase }\end{array}$ \\
\hline & Simpson & 231.302 & 34586.234 & -0.1 & $\begin{array}{l}- \\
3227.321\end{array}$ & $\begin{array}{l}y \text { value } \\
\text { increase }\end{array}$ \\
\hline
\end{tabular}

Based on data analysis $\mathrm{R}^{2}$, simple linear regression, and comparison result between Simpon index and Shannon-Wiener, therefore the possible assumptions are the crab density may not response to the changing of mangroves diversity, then crab diversity and richness may response a lot on mangroves diversity or in the other words mangrove diversity increase and aslo crabs diversity and richness will increase as well. Concerning on the relationship between mangrove diversity and crab density it will discuss later, next we are going to discuss about the possible reason of the relationship between mangroves diversity and crab community (diversity and richness).

a. The relationship between mangrove diversity and crab community (diversity and richness)

Several biological and ecological factors contributed on this positive relation between crab and mangroves. First, the physical characteristic of mangroves three species and the substrates as microhabitat are offering significant contribution on this relationship. Each characteristic of mangrove trees can provide a suitable habitat for crab species, for example the roots system, there are six types of mangrove root (Kathiresan \& Bingham 2001), however the knee root and still root are the best for crab habitat. There are 12 types' os substrates, such as, clay, clay-muddy, flat rocky, gravels-sand, muddy, muddy-clay, muddysand, muddy-sand-gravels, sandy, sandy-gravels, sandy-gravels, and sandy-mud 
substrate (See Table 11). The suitable habitat is very important for mangrove trees and crab; the high diversity of habitat in a mangrove area positively indicated mangrove trees and crabs diversity is high, oppositely low habitat diversity indicated mangrove trees and crab diversity is low. We have found that coastline have more variances on crabs habitat than other cluster stations (Appear in Figure 10 and 11), yet mangroves species and crabs species are more divers in coastline then other area (See in Figure 15).

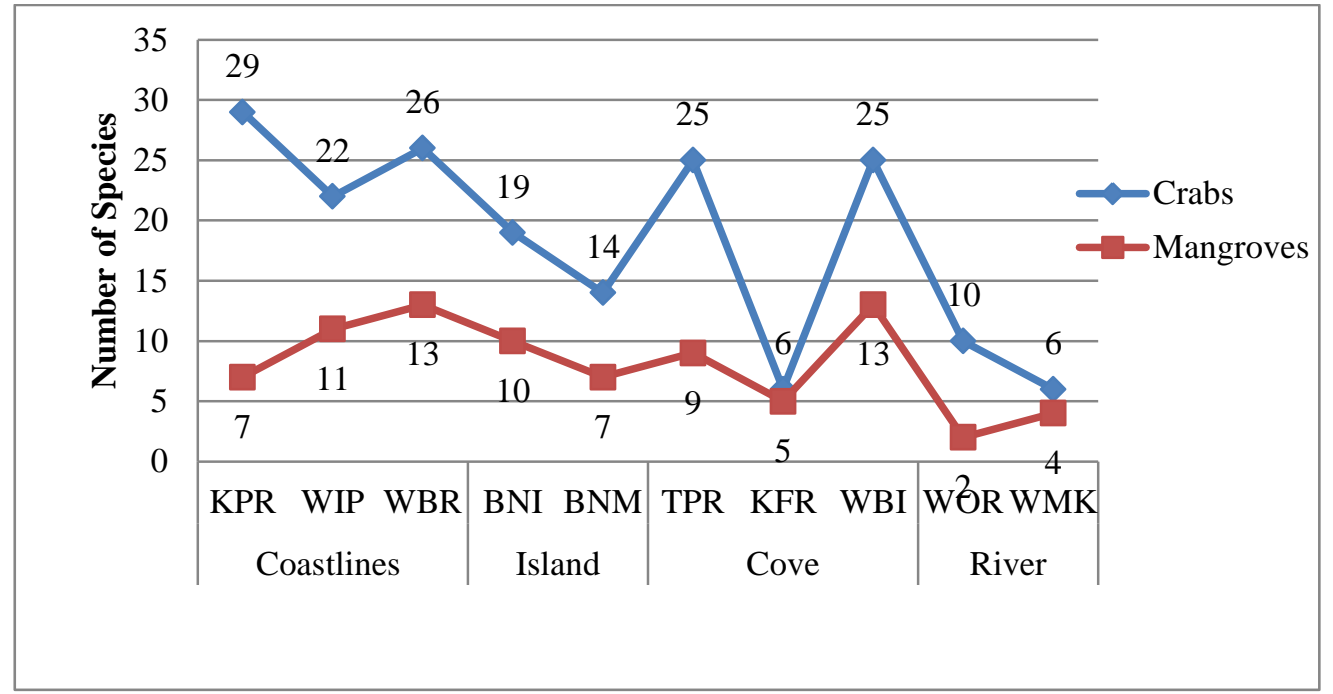

Figure 15. The Comparison between Mangroves and Crabs diversity in Mangrove cluster Notes: KPR is Station Kapisawar; WIP is Station War Iprim; WBR is Station War Beren; BNI is Station Bun Iba; BNM is Station Bun Mkun; TPR is Station Tapor Pandera; KFR is Station Kim Far; WBI is Station War Beki; WOR is Station War Ongkor, WMK is Station War Manak.

Second, mostly mangrove crabs are herbivores; it denotes crabs needs mangroves leafs and propagules for their food (Brown, 1992, Mcivor \& Smith III, 1995; Kathiresan \& Bingham, 2001; Macintosh \& Ashton 2002; Soundarapandian, 2008). There are two herbivores crab families in Gam, such as Ocypodidae and Sesarmidae. Ocypodidae Crab is the greatest family in Gam Bay, there is 28 species on this family or $53 \%$ of mangroves crab diversity (Appear in table 17, 19 and 20), they feed on decaying plant material present in salt marsh mud and sediment. Sesarmidae crab has 17 species, distributed on entire area or $32 \%$ of total mangrove crabs species in Gam Bay area (Appear in table 17, 19 and 20), again Sesarmidae crab often uses mangrove three as their habitat and feeding on it, especially Rhizophora mangroves trees. According to 
Brewer (1990), that selective herbivore plays in determining the species composition of vegetation, although his argue is substantial poorly known. On the other hand, Brewer (1990) gives emphasis that herbivore and predation may increase species diversity of vegetation by preventing competitive exclusion from going to completion. An example, there are two locations have dominance by two mangrove species Brugeria sexangula and Rhizopora mucronata, both locations are St. War Manak and St. War Ongkor (See Table 15). In these locations we found six crab species at St. War Manak and 10 crab species in St War Onkor, While St. War Beki have 13 mangrove species, have 25 species of crab (See Table 15 and 19). This example tells us that the places with many mangrove species may have a great crabs diversity and richness (Appear in Figure 16).

Other possible reason for this relationship is the types and the physical characteristic of mangroves ecosystem, in Gam Bay there are four cluster of mangrove ecosystem, such as coastline mangrove ecosystem, rivers, coves, and small islands (See in Figure 15). Each location has different type of habitat (Appear in Table 22, Figure 10, and 11), therefore some mangroves species may be found in an area and others area no. According to Suryani (2006), state on her thesis, that Scylla serata population is following the cluster pattern of mangrove ecosystem in Enggano Island, Bengkulu Province, Indonesia. We have found the same things in Gam Bay, where species diversity, richness of mangrove crabs are follows the clusters of ecosystem and the availability of suitable habitat (See Figure 10, 11, and 15).

Species distribution of crab is also contributes to this relationship. Ocypodidae is good example for this factor. This species itself contribute $53 \%$ of crab diversity in Gam Bay area. Because this group of species has good ability to live in different ecological charactersics of mangrove ecosystem or they have large homeranges, therefore they play siginificant contribution on this type of relationship. The distribution ability of 53 crabs species are well describes at table 15, some among them are, Uca crassipes, Uca sp 12, are present at 7 different stations or $70 \%$ of entire area. While, Uca sp 02, Uca sp 20, Uca sp 21, and Uca sp 22 (See Figure 16).

Other factors contribute to this relationship is the migratory species, we recognize two species as the migratory species, Thalamita creanata are often 
appearing in sea-grass ecosystem and Myomenippe $s p$. is often in the coast land nearby the mangrove ecosystem. There are five stations are connect with sea grass and coral ecosystem directly, such as St. War Iprim, St. War Beren, and St. Kim Far, St. Bun Iba, and Bun Mkun, While St. War Beki is connected with sea grass ecosystem. Thalamita creanata is appearing in St. Bun Iba, St.War Kim Far, and St War Beki. While these two crabs Selatium spp and Metopograpsus frontalis (Miers, 1880) both of them are the climbing crabs, they move from one microhabitat to another microhabitat in mangrove ecosystem. Within this thesis, we assume that there are some species as the true mangrove crabs and the untrue mangrove crabs. The true mangrove crabs mean mangrove crabs species are only found in mangrove forest ecosystem. The migratory mangrove crab means the individual crabs species are often found in two or more different ecosystem, and then we can describe them as untrue mangrove crab. Therefore, the migratory species will be excluded in this classification it means we have 50 true mangrove crabs.

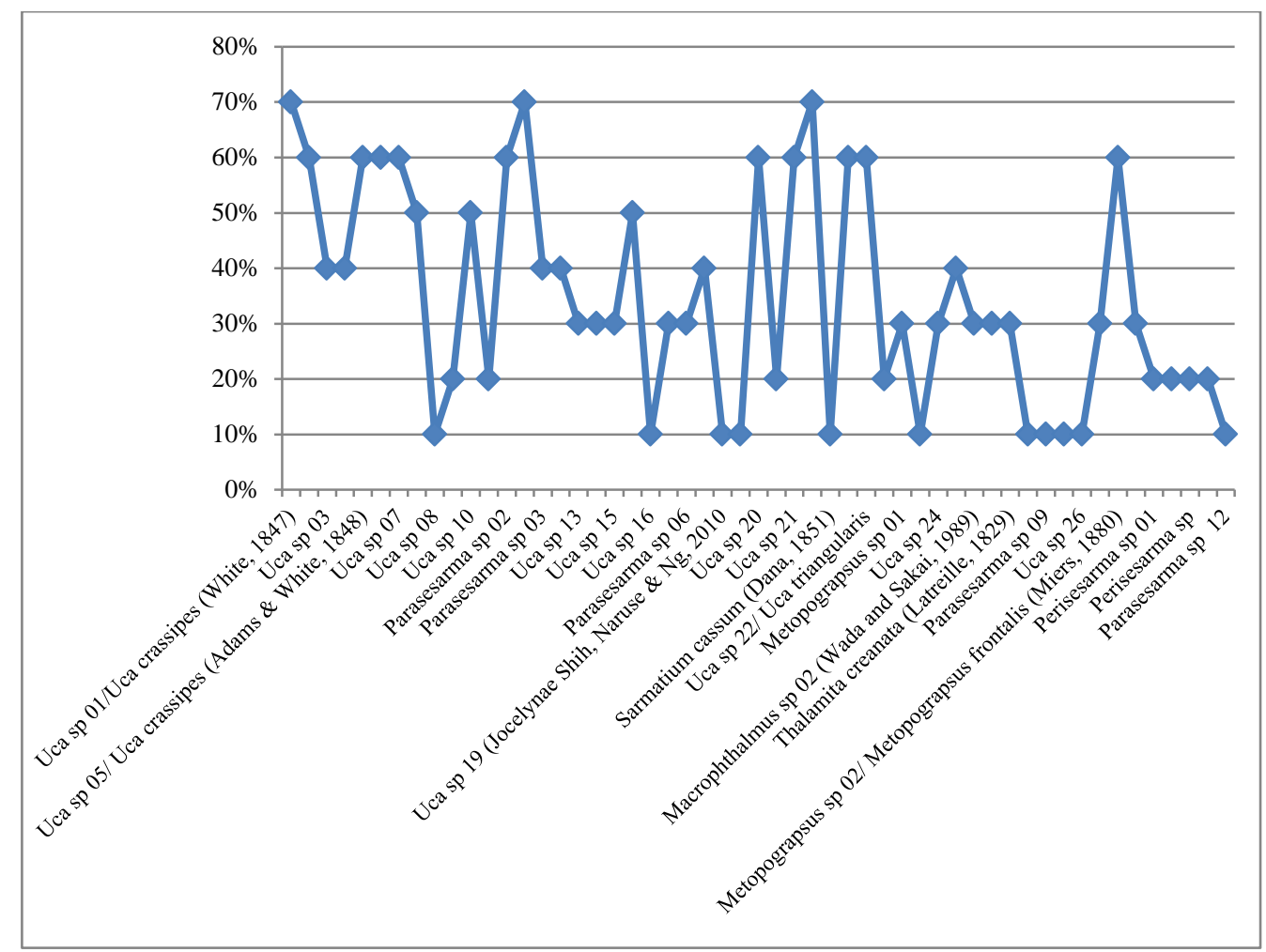

Figure 16. The Home Range of Crabs Species at Ten Station in Raja Ampat

Ecologically, if an environment change by succession on a mangroves ecosystem, it will affect many ecological component, includes the species 
diversity of mangroves. Human impacts on mangrove ecosystems will decrease the stability and integrity these ecosystem, includes the number of mangrove trees species. On the other hand the changing of mangroves diversity could change the structure of mangrove crabs population, includes crab diversity and crab richness. Although in this time we not have enough data to support the impact of human activities on mangrove ecosystem and crab community. However, we argue that human impacts are significantly decreasing the crabs' diversity. We assume that Ocypodidae and several Sesarmidae crabs have high ability to diffense their commubity toward human influences on mangrove forest ecosystem. There these two families are good candidate to measure and discribe the impacts of human activities on mangrove ecosystem. For example, Ocypodidae crabs, although a mangrove ecosystem is close at the village, we are able to find this crab, for example St. Kapisawar, in this place it looks like no distance at all between this group of species and village.

b. The relationship between mangrove diversity and crab community (density) The dependence of crab diversity and richness on mangroves diversity is reasonable. However it is different with the correlation mangroves diversity and crabs density. There are many factors contribute to the density of mangrove crab, two main factors are natality or birth rate and mortality or death rate of a population. These factors are density dependent factors (Odum, 1971; Ricklefs, 1990; Brewer, 1994) that contribute to fluctuation and stabilizion of crab population.

Beside those factors above there is physical stress of ecosystem as the external factor (Odum, 1971). This physical stress or density independent factor is unpredictable due to physical component alteration, such as weather, water current, chemical limiting factors, pollution and so forth (Ricklefs, 1990). For example, the weather condition particularly in rainy day, the crabs will choose to hide in their burrow during the rain. We assume that the crab population might be decreased during the rainy season and may have low density. Because they will have limitation for feeding and access the resources, this limited factor base 


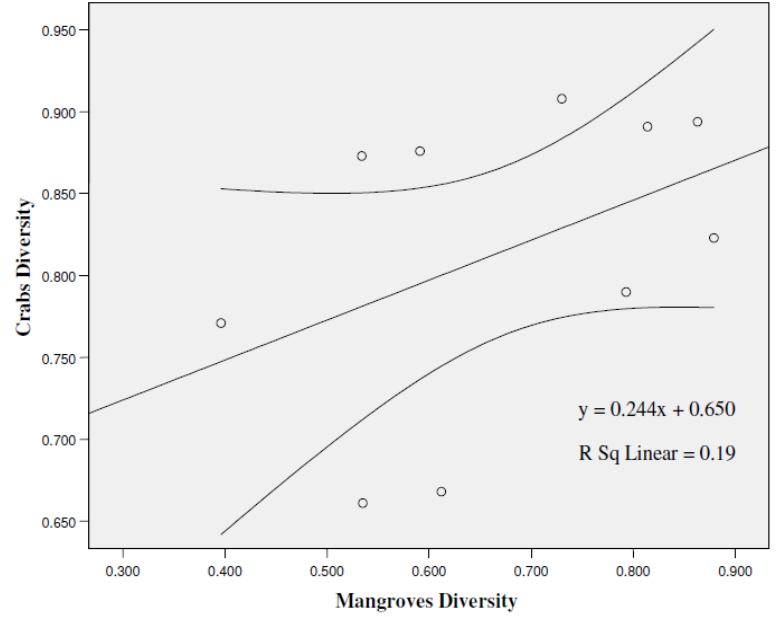

a.1.

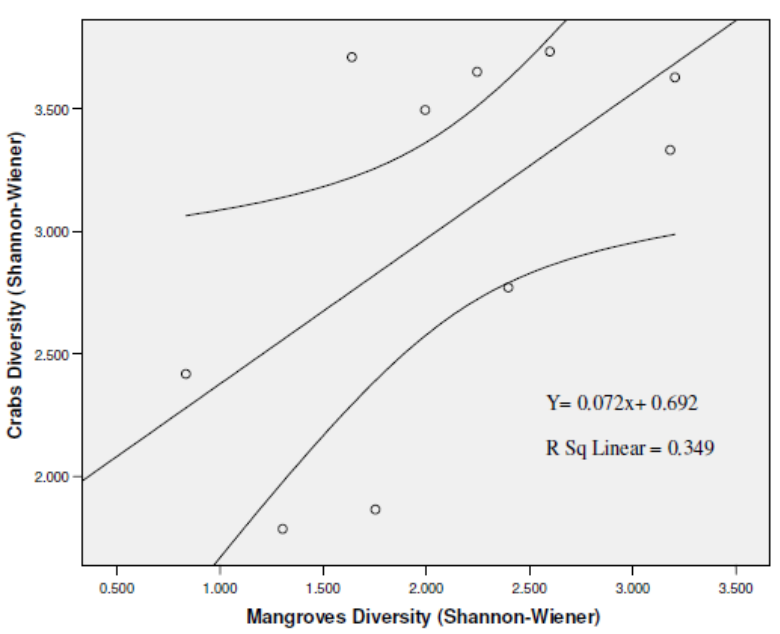

a.2.

a. The relationship between mangroves diversity and crab diversity, where mangrove diversity is the independent variable, and crabs diversity is dependent variable; a.1. is the comparison using the Shannon-Wiener index, and a.2. Simpson. Both diagram showing a petite relationship.

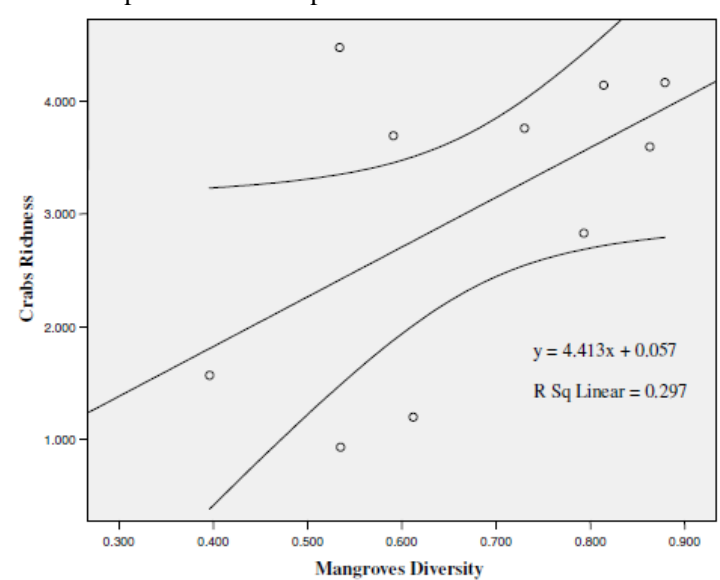

b.1.

b. The relationship between mangroves diversity and crab richness, where mangrove diversity is the independent variable, and crabs richness is dependent variable; b.1. is the comparison using the Shannon-Wiener index, and b.2. is Simpson index. Both diagram showing strong enough relationship.
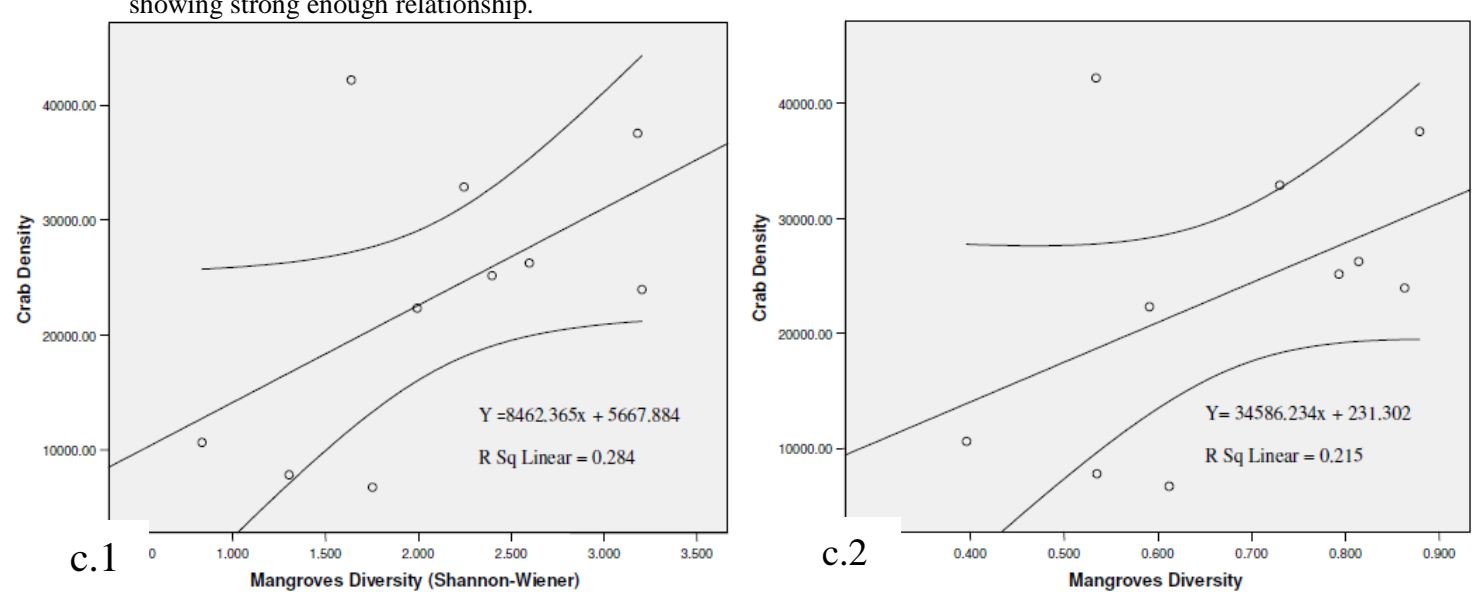

Figure 17. The Relationship between Habitat Diversity and Crabs Community: Crab Diversity, Richness, and Density

c. The relationship between mangroves diversity and crab density, where mangrove diversity is the independent variable, and crabs density is dependent variable; c.1. is the comparison using the Shannon-Wiener index, and c.2. using the Simpson index. Both diagram showing very weak relationship. 
Ocypodidae Crab or fiddler crabs are influenced more on this relationship, due to this crab is often feeding on the ground at the low tides circumstances and often living together in larges cluster, and has great numbers of species is about 28 species on this family or $53 \%$ of mangroves crab diversity (Appear in table 18). During our field observation we distinguish this particular crabs behavior, where crab are being inactive during the rainfall, and is being active again where the rain stop. For example, if the rain was coming, then we have to wait for a couple hours until the rain stopped, and again we waiting for around 30- 40 minutes more, because the crab does not immediately do their daily activities, they will wait until the ground was well dried of, then continue with their activities (This behavior was recognized during the crab observation in the field). Therefore crabs have limited times to access the resources and do their daily activities, includes feeding and breeding. As consequence the changing of this family will change a lot to the number of species and density of crab community in Gam Bay. These circumstances directly effect to fluctuation of crab density, however it would be depended on the frequency of the rain itself. We realized that too difficult to draw the relationship between this explaination and the mangrove trees diversity.

However, based on density dependent factors and density independent factors of mangrove crab community, we may not easily accept the result of the linear regression analysis. Probably the high numbers of mangrove species indicate the lowest mangroves density, it could be represented there were any gaps or spaces among individual mangrove species (this statement will be discussed later in the relationship between mangrove density and crab community). It means there are suitable habitats and feeding ground for crab species, therefore we are be able to find a various populations of crabs over there. These circumstances appear in several stations in Gam Bay, Such as St. Kapisawar, St. War Iprim, St. War Manak, and St. Tapor Pandera. Base on this viewpoint, we suggest the mangroves diversity as the indirect factors on crab density, because we realize and we knew the $x$ values of crab density can be predicted base on the linear regression analysis, therefore it could be recommended topic for the future research. According to Wisley and Stirling (2001) that empirical relationship observations could not be explained without including indirect effects. 
The explanation on this relationship between mangrove diversity and crabs density is not clear yet. Therefore the future research is recommended about this topic and should be focused on Sesarmidae crab, especially genus Parasesarma and Perisesarma. Here on this observation we find there are seven species of Sesarmidae crab in St. War Manak and War Ongkor, such as: Parasesarma sp 07 with 56 individual, Parasesarma sp 08 with 105 individual, Parasesarma sp 11 with individual, Metopograpsus frontalis (Miers, 1880) with 4 individuals, Perisesarma sp 02 with 183 individual, Selatium sp 02 with 9 individual, and Parasesarma sp 12 have 1 individual. In other hand the total mangroves density in St. War Onkor is 649.631 individual/ha and St. War Manak is 1524.762 individual/ha (See Table 18), and the total density of crab in St. War Manak is about 7823.19 and in St, War Ongkor is about 10641. We believe it would be significant relationship between mangrove density and Sesarmidae crab community in both areas.

\section{The Association between Mangroves Richness and the Mangrove Crabs Community: Diversity, Richness, and Density}

There are number of factors to which the species richness of a community can be related, such as geographic, productivity of environment, climatic variability, and the age of environment, and then the harshness of the environment (Begon, et al. 1990; Primack, 2006). Others group of factors are the biological attributes, Begon and friends (1990) state four factors, three of them such as, productivity, the spatial or architectural heterogeneity generated by the organisms themselves, and the succession status of a community (Begon, et al. 1990). However, within this section we want discuss about how the mangrove richness are correlated with mangrove crabs community.

The values of coefficients correlations have proved crab diversity and richness have strong relationship with mangroves richness, than crab density have weak relationship (Appear in table 29 and and Figure 18). The great values of $\mathrm{R}^{2}$ indicate mangrove richness is affected crab community, it means positively the diversity and richness of mangrove crabs are influences by mangrove richness. Whereas the tiny values of $\mathrm{R}^{2}$ states the mangrove richness may not significantly influences the crab community. Similarity with the linear regression equation, where the mangroves richness positively increases the ecology community of mangrove crabs. In this case, the $x$ value (the richness values of mangroves) is 0.1 , and then diversity value, richness 
value, and density value of mangroves crabs are increasing (Appear in table 30 and and Figure 18).

Table 29. The Relationship among the Mangrove Richness and Crabs Community: Diversity, Richness, and Density

\begin{tabular}{|c|c|c|c|}
\hline \multicolumn{2}{|l|}{ Comparison } & $\mathrm{R}^{2}$ & Correlation \\
\hline \multirow{2}{*}{$\begin{array}{l}\text { The Relationship among mangroves richness } \\
\text { and mangrove crabs diversity }\end{array}$} & Shannon-Wiener & 0.579 & Significant \\
\hline & Simpson & 0.502 & Significant \\
\hline \multicolumn{2}{|c|}{$\begin{array}{l}\text { The Relationship among mangroves richness and mangrove crabs } \\
\text { richness }\end{array}$} & 0.611 & Significant \\
\hline \multicolumn{2}{|c|}{$\begin{array}{l}\text { The Relationship among mangroves richness and mangrove crabs } \\
\text { density }\end{array}$} & 0.443 & Significant \\
\hline
\end{tabular}

In point of fact the species richness is comparable with the diversity (Primack, 2007), according to Begon et al. (1990) species richness is the number of species present at a site. Its mean the result of the regression analysis of mangrove diversity and their variables may represent the regression analysis mangrove richness. On other world, the reason why the mangrove richness may affect on crab community, it is similar with the mangrove diversity relationship analysis, includes the relationship between mangroves richness and crab density (See Chapter V. B.1. The Association between the Diversity of Mangroves and Mangrove Crabs Community)

Table 30. The Relationship among Mangrove Richness and Mangrove Crabs: if $\mathrm{x}=\mathbf{0 . 1}$

\begin{tabular}{|l|l|l|l|l|l|l|}
\hline Comparison & \multicolumn{1}{c|}{$\mathrm{a}$} & $\mathrm{b}$ & $\mathrm{x}$ & $\mathrm{y}$ & Explanation \\
\hline $\begin{array}{l}\text { The Relationship } \\
\text { among mangroves } \\
\text { richness and mangrove } \\
\text { crabs diversity }\end{array}$ & $\begin{array}{l}\text { Shannon- } \\
\text { Wiener }\end{array}$ & 0.692 & 0.072 & 0.1 & 0.699 & $\begin{array}{l}\text { increasing the } \\
y \text { value }\end{array}$ \\
\cline { 2 - 8 } & Simpson & 1.922 & 0.650 & 0.1 & 1.987 & $\begin{array}{l}\text { increasing the } \\
\text { value }\end{array}$ \\
\hline $\begin{array}{l}\text { The Relationship among mangroves } \\
\text { richness and mangrove crabs } \\
\text { richness }\end{array}$ & 1.063 & 1.149 & 0.1 & 1.178 & $\begin{array}{l}\text { increasing the } \\
y \text { value }\end{array}$ \\
\hline $\begin{array}{l}\text { The Relationship among mangroves } \\
\text { richness and mangrove crabs density }\end{array}$ & 8511.051 & 8767.008 & 0.100 & 9387.752 & $\begin{array}{l}\text { increasing the } \\
y \text { value }\end{array}$ \\
\hline
\end{tabular}



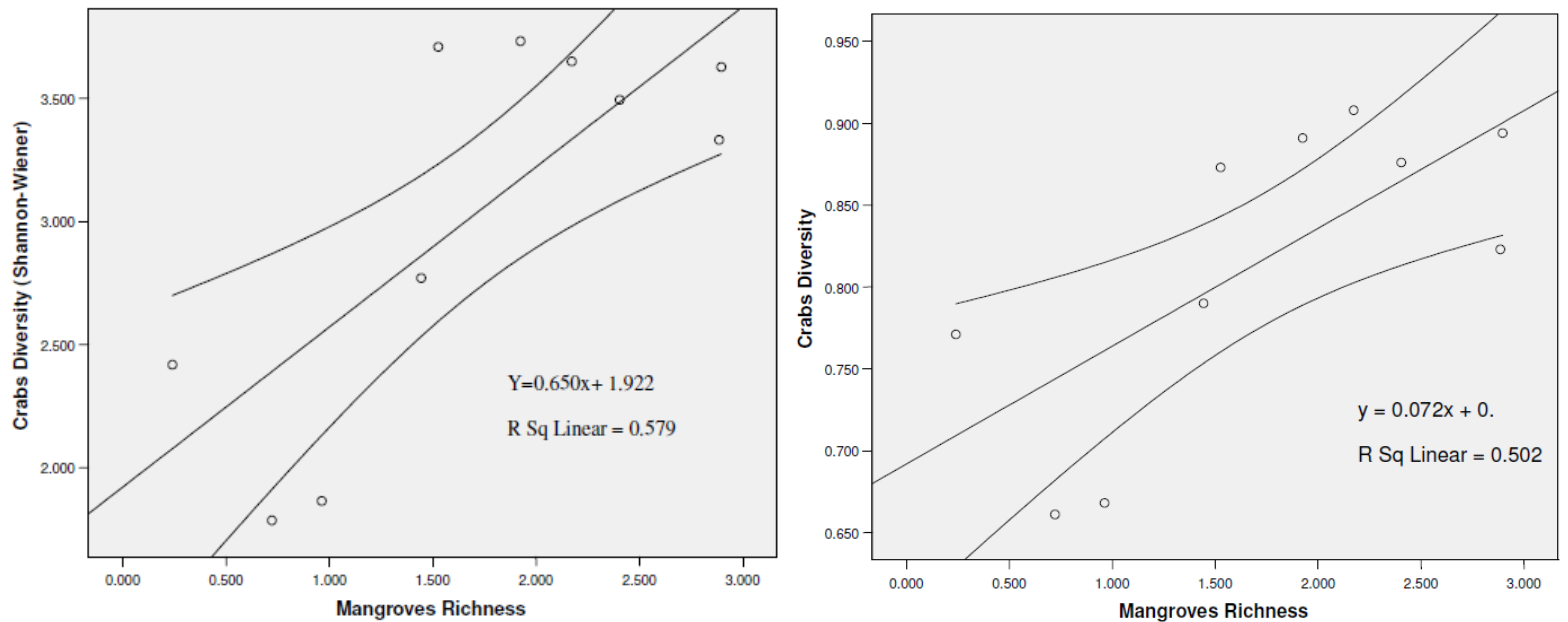

a.1
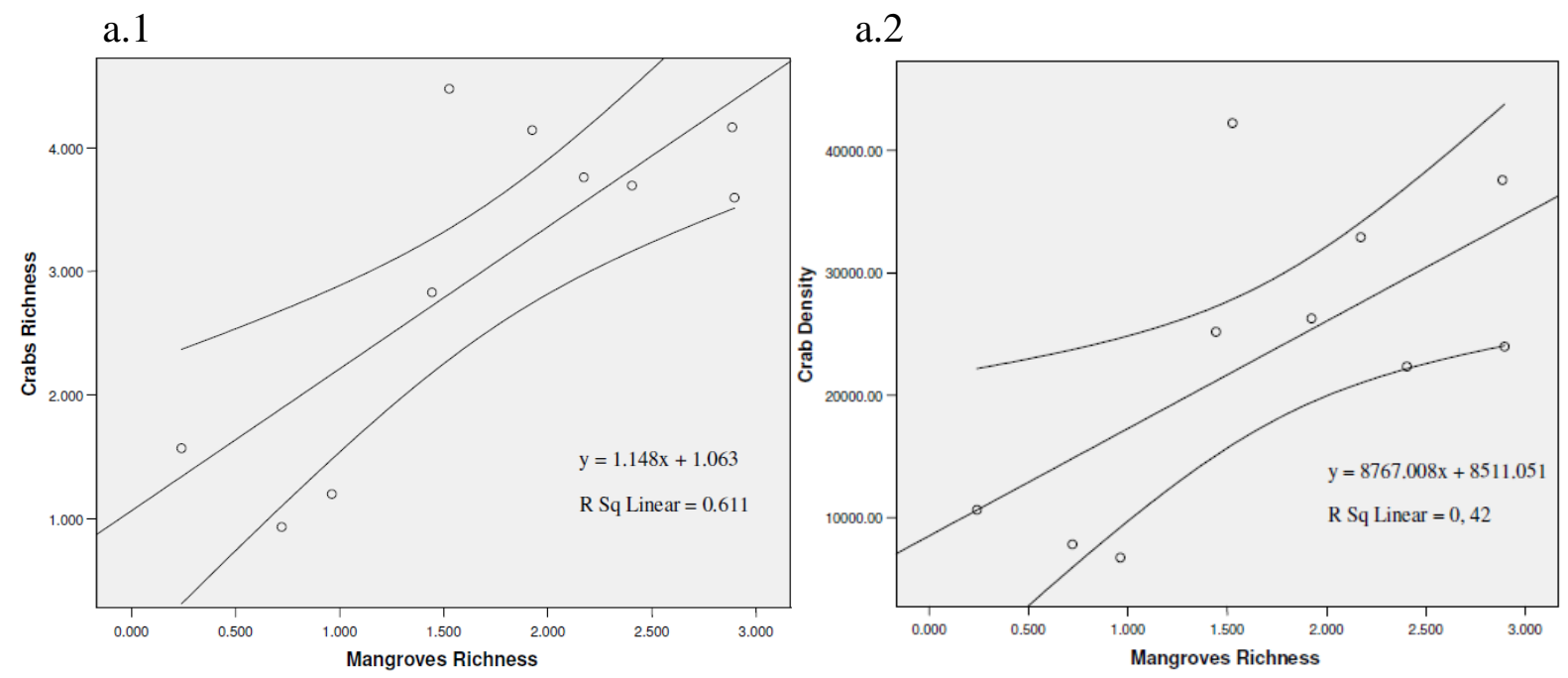

$b$.

$c$

Figure 18. The Relationship between Mangroves Richness and Crabs Community: Crab Diversity,

Richness, and Density

Where mangrove richness is the independent variable, and crabs community (diversity, richnees, and density) is dependent variable; a.1. Mangrove richness and crab diversity of the Shannon-Wiener index, and a.2. Mangrove richness and crab diversity of the Simpson index. Both diagram showing strong relationship; $b$. Relationship mangrove richness and crab richness, where the relationship is strong anough , $c$. Relationship mangrove richness and crab density, where the relationship is not too strong . 


\section{The Association between Mangroves Density and the Mangrove Crabs Community: Diversity, Richness, and Density}

Table 31. The Relationship between Mangrove Density and Mangrove Crab Community: Diversity, Richness, and Density

\begin{tabular}{|l|l|l|l|}
\hline \multicolumn{2}{|l|}{ Comparison } & $\mathrm{R}^{2}$ & Correlation \\
\hline $\begin{array}{l}\text { The Relationship among mangroves density } \\
\text { and mangrove crabs diversity }\end{array}$ & Shannon-Wiener & 0.712 & Significant \\
\cline { 2 - 5 } & Simpson & 0.696 & Significant \\
\hline $\begin{array}{l}\text { The Relationship among mangroves density and mangrove crabs } \\
\text { richness }\end{array}$ & 0.619 & Significant \\
\hline $\begin{array}{l}\text { The Relationship among mangroves density and mangrove crabs } \\
\text { density }\end{array}$ & 0.443 & Significant \\
\hline
\end{tabular}

The coefficients correlations values and the linear regression (See the Figure 19, Table 31 and 32) are well illustrating how the association pattern between communities, mangrove density and crab community. All variables of crab community have strong relationship with the mangrove density, so called negative linear relationship (McCarthy, 2007). Within the linear regression, crabs community is predicted by mangroves density value (Appear in Table 32), in this case we are deal with the $x$ value of mangroves density is 0.1 , then we got the $y$ values of crab community are increasing. Yet, the graph shows all components of mangrove community have strong relationship with the mangrove density, where the average of coefficient correlation values $\left(R^{2}\right)$ is about 0.586 (See the Table 31).

Table 32. The Relationship among Mangrove Density and Mangrove Crabsif $\mathbf{x}=\mathbf{0 . 1}$

\begin{tabular}{|l|l|l|l|l|l|l|}
\hline Comparison & $a$ & $b$ & $\mathrm{x}$ & $\mathrm{y}$ & Explanation \\
\hline $\begin{array}{l}\text { The Relationship among } \\
\text { mangroves density and } \\
\text { mangrove crabs diversity }\end{array}$ & $\begin{array}{l}\text { Shannon- } \\
\text { Wiener }\end{array}$ & 0.973 & 0.000 & 0.1 & 0.973 & $\begin{array}{l}\text { increasing the } \\
y \text { value }\end{array}$ \\
\cline { 2 - 8 } & Simpson & 4.350 & 0.002 & 0.1 & 4.350 & $\begin{array}{l}\text { increasing the } \\
y \text { value }\end{array}$ \\
\hline $\begin{array}{l}\text { The Relationship among mangroves } \\
\text { density and mangrove crabs richness }\end{array}$ & 5.165 & -0.003 & 0.1 & 5.165 & $\begin{array}{l}\text { increasing the } \\
y \text { value }\end{array}$ \\
\hline $\begin{array}{l}\text { The Relationship among mangroves } \\
\text { density and mangrove crabs density }\end{array}$ & 40141.660 & -23.857 & 0.1 & 40139.274 & $\begin{array}{l}\text { increasing the } \\
y \text { value }\end{array}$ \\
\hline
\end{tabular}

The relationship between mangrove density and all variables of crab community, such as diversity, richness, and density are comparable, where mangrove density goes up then crab diversity, richness, and density goes down. Mangrove density goes down 
then crab diversity, richness, and density goes up. This correlation situation is a causeand-effect relationship (Johnson \& Bhattacharyya, 1996).

How mangrove density affected on crabs diversity, richness, and density? And how crabs would response to changeability of mangrove density? These are important questions to be solved. In order to discuss those questions, we need to determine which factors lead on the negative association between mangroves density and crabs community. Overall the descriptions below explain the possible factors and description on this relationship.

a. The relationship between mangrove density and crab community (diversity and richness)

Ecologically, the mangrove ecosystem is the habitat for many crab species. Two important components of mangrove ecosystem for crab community are various substrates and anaerobic soil (Kathiresan \& Bingham, 2001; Alongi, 2007). The habitat suitability and physical habitat characteristic are important for individual crab. Unlike plant, most plant can not choose where they grow and survive (Ricklefs, 1990), animals includes crab can choose where they live. Those may allow the individual crab to follow the most suitable condition within a habitat. Commonly, the dead wood stems of mangroves three are often appear on a mangroves ecosystem, and beside that others micro habitat is the mangrove roots system as other suitable habitat for mangrove crab. A mangrove area with low density indicated there are more spaces or gaps on mangrove ecosystem, a gap may occur because of falling threes and a particular morphological characteristic of mangroves ecosystem. According to Brewer (1990) communities and ecosystems are dynamic, they change constantly, one tree dies and sapling will grow up to take its place. Therefore, we added to be the crab habitats as well, such us various substrates, the dead stems of mangroves, and the root system of mangroves.

In mangrove ecosystem, we are able to find the various micro habitats for crab (See Table 11, 22, figure 10, and 11). Habitat diversity in an ecosystem is contributed to the availability of species, its mean that mangrove ecosystem can support more crabs species for life by provides fundamental niche, such as habitat, food, and others resources. On the other side, the adaptation ability for live in different type of habitat on the mangrove ecosystem also contributes to the geographic ranges of mangrove crabs species (See Table 19), however these 
two factors is parallel. It is indicate that not every crab can present in a particular mangrove ecosystem, it will depend on the ability to find suitable habitat and their home range. We have found that mangrove ecosystem in coastline have low density than other stations (Appear in Figure 10 and 11), because this types of mangrove ecosystem provide suitable fundamental niche for many crabs species, therefore on this particular mangroves ecosystem have high numbers mangrove crab species (Appear in Figure 15).

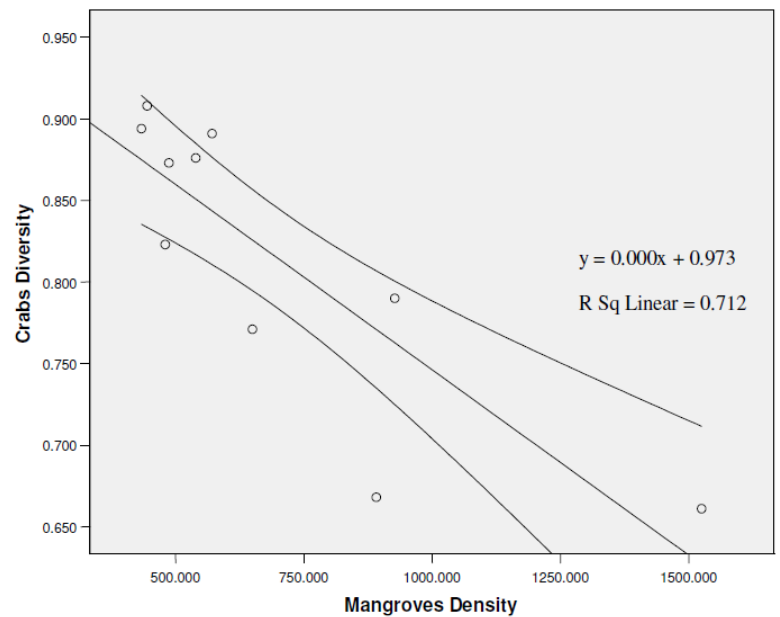

a. 1

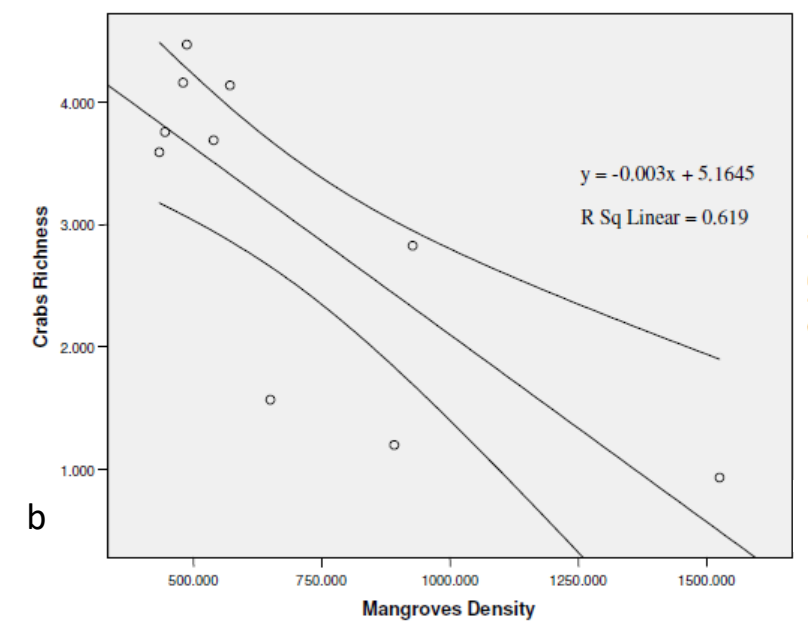

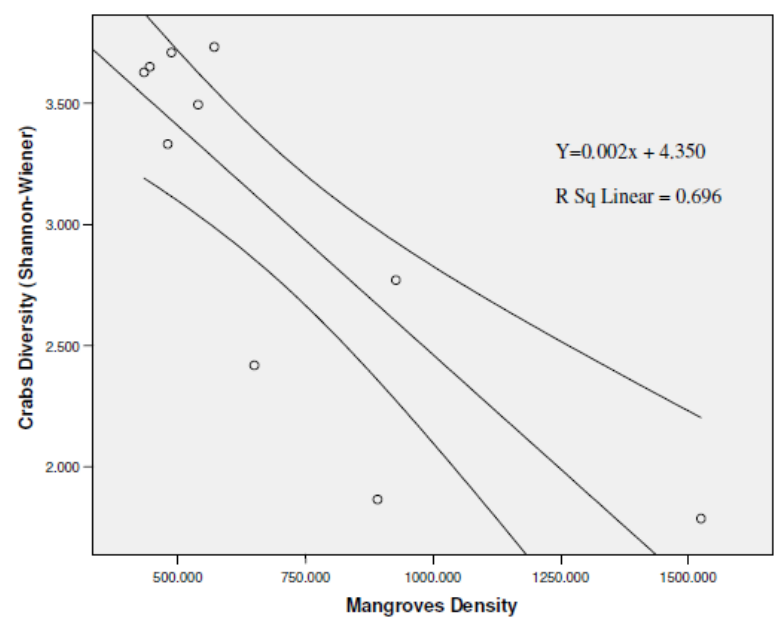

a. 2

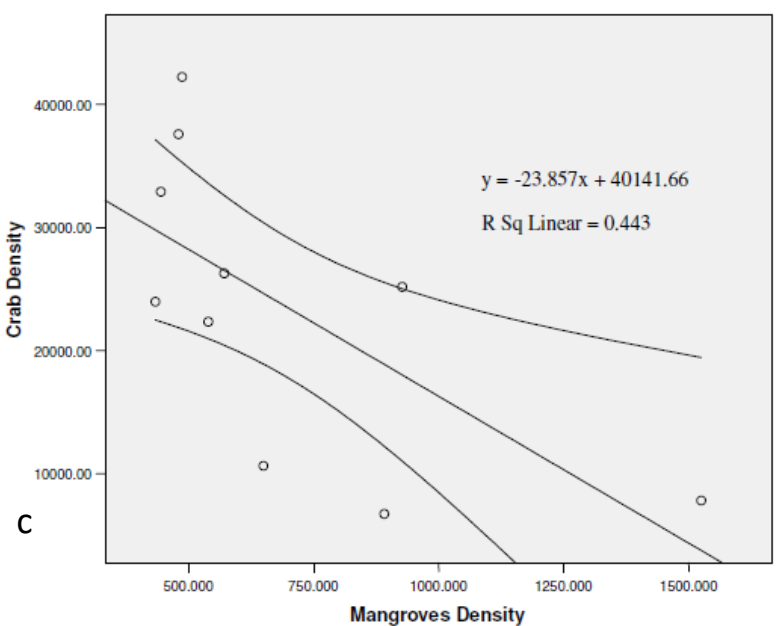

Figure 19. The Relationship between Mangroves Density and Crabs Community: Crab Diversity, Richness, and Density

The relationship between mangroves density and crab community, where mangrove density is the independent variable, and crabs density is dependent variable; $a .1$. is the relationship between mangroves density and crab diversity (the Shannon-Wiener index), a.2. is the relationship between mangroves density and crab diversity (the Simpson index), $b$. is the relationship between mangroves density and crab richness, $c$. is the relationship between mangroves density and crab density. All relationship between mangroves density and crabs community (Crab diversity, richness, and density) shows negative linear relationship. 
The figure 20 is confirmed on that explanation, where habitat diversity is higher than mangrove ecosystem which has low density (Figure 20.d.). Where the relationships between habitat diversity and crabs community (crab diversity, richness, and density) have shows positive linear relationship (Figure 20.a1. 20. a2., 20.b, and 20.c.), while the relationship between mangrove density and habitat diversity has show negative linear relationship (Figure 20.d). Its means, the high or low habitat diversity will increased or might be decreased crab diversity and richness, then crab community is depend of habitat diversity. While, high habitat diversity are indicated mangrove density is low. Oppositely, low diversity of habitat states mangroves density is high. These correlation situations are cause-and-effect relationship, where mangrove density is high than habitat diversity is low in, while crab communities have low diversity and richness. If, mangroves density are low than habitat diversity is high than crab community has high diversity and richness.

Food and resources are also important factors for this relationship. Ecologically, most animals choose their food to be eaten, includes mangrove crabs. Base on the food web structure, within a mangrove crab community there are primary consumers, secondary consumers. Those crabs that eat secondary consumers are called tertiary consumers and crabs that eat the dead bodies of organisms or their waste products are called detritivores or decomposers. Here, we are able to categorize Ocypodidae crab (28 species or $53 \%$ of total mangrove crabs) and Glyptograpsidae crabs Eriphiidae (2 species or $3.77 \%$ ) as the decomposer species. Then, Sesarmidae crab (17 species or $32 \%$ of total crabs species) are secondary consumer and decomposer, 1 Species Dotillidae crab is Ilyoplax sp (1 species or $1.8 \%$ ) and Macrophthalmidae crabs (2 species or $3.77 \%$ ) are the decomposer species, and there are tertiary consumer or predator species such as, Eriphiidae ( 2 species or $3.8 \%$ ), and 1 Species Ocypodidae crab is Ocypode pallidula (1 species or $1.8 \%$ ). We assume that low density of mangrove ecosystems provide limited food and other resources, therefore this ecosystem are appropriate for the secondary consumer and decomposer, here we find Sesarmidae crab (17 species or $32 \%$ of total crabs species) are fulfill this circumstances, for example in St. War Manak and St. War Ongkor, both location has high density of mangrove ecosystem, therefor in both location have high number Sesarmidae crabs. 
Low density of mangrove ecosystem has provided a complex food web system and variety of foods for crabs, therefore many crab species present on this type of ecosystem. On the other hand high density of mangrove ecosystem provides limited food and resources. Low density of mangroves indicated there are many suitable habitats for crabs, each habitat provides a specific resources and food. Oppositely, high density of mangrove ecosystem may supply limited resources and foods. Again this description is needed more detail information, therefore we suggest this topic for the future research about the ecological community of mangrove crabs: the food web structures.

The species interaction in a community is another factor wich is contributed to the relationship between mangroves density and crabs community (diversity and richness). However, this internal factor significantly contributes to the relationship between mangroves density and crab community (diversity and richness). Due to many crab species in Gam Bay area have good ability to share their microhabitat with others (See Figure 21). If, individual crabs species are often appear together with other species in different habitat, indicates that species have strong interactions ability, called the inter-associated ability or the ability of crab species to share their micro habitat with other different crabs' species. This situation habitually occurs in a low density level of mangrove forest ecosystem, such as St. Kapisawar, St. Sawinggrai, and St. War Beren. This perspective will have different connotation for predator species, because the presences of predator species is related to the food web. According to Ricklefs (1990) all interaction between species are strictly additive and are independent of the presences or absences of other species.

These three components, variety of habitat, the number of species, and the level of species interaction have a significant relationship. It means the habitat diversity increase, and numbers of species are increase as well, if the number of species increase then the level of interaction among species will increase and is being more complex. Table 21 shows the numbers of crab species, which is allowed to share their micro habitat with other species. The graphic below shows the number of species are often appear together in a micro habitat or the main habitat at ten stations in Gam Bay area (See Figure 22). The ability of crab species to share a micro habitat, such as 27 species of Ocypodidae crab, 16 
species of Sesarmidae crab, 2 species of Macrophthalmidae, 2 species

Glyptograpsidae, and 2 species of Metopograpsus (See table 21).

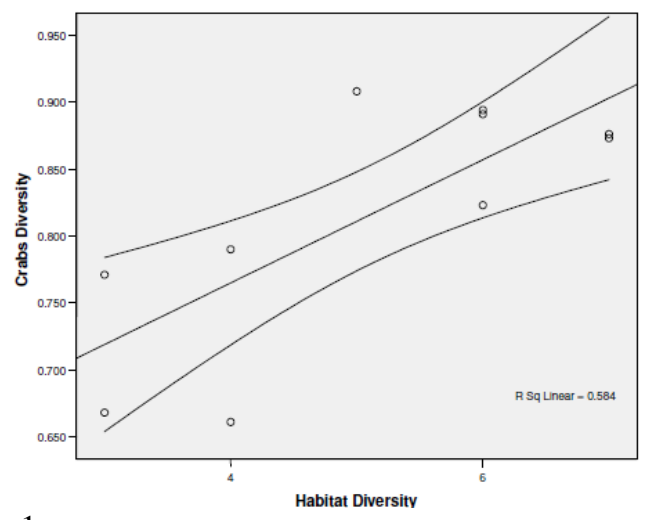

a1.

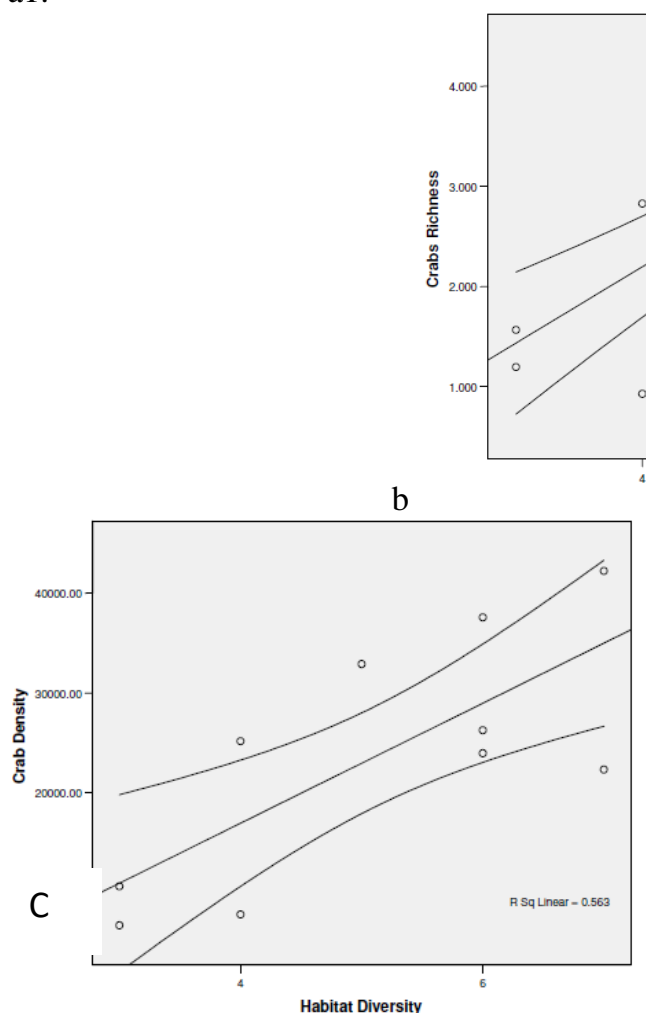

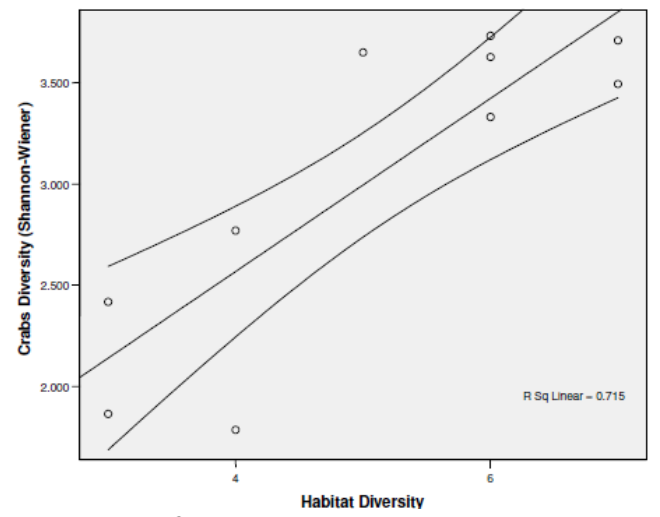

a.2

Figure 20. The Relationship between Habitat Diversity and Crabs Community: Crab Diversity, Richness, and Density

a.1. the relationship between habitat diversity and crab diversity (the Shannon-Wiener index), a.2. the relationship between habitat diversity and crab diversity (the Simpson index), $b$. the relationship between habitat diversity and crab richness, $c$. the relationship between habitat diversity and crab density, $d$. the relationship between habitat diversity and mangroves density. 


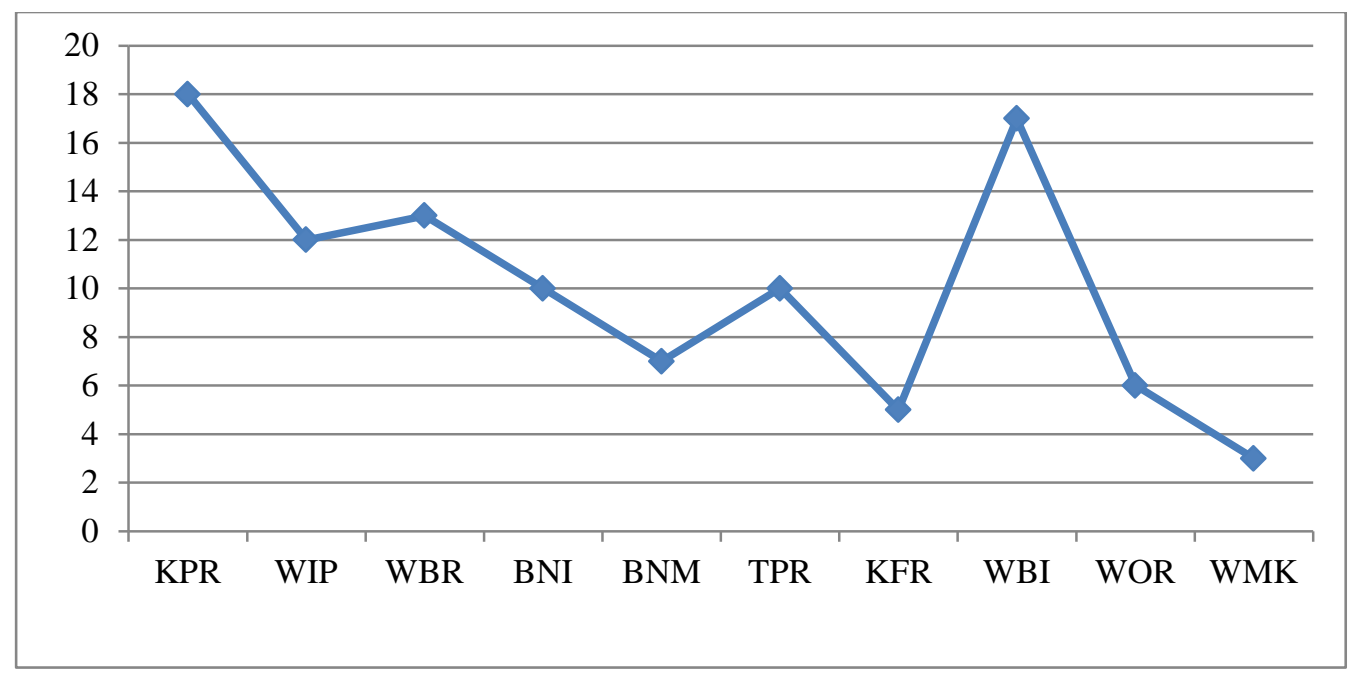

Figure 21. The Numbers of Mangrove Crabs Species are often appear together at Ten Station in Gam Bay Area

Notes: $K P R$ is Station Kapisawar; WIP is Station War Iprim; WBR is Station War Beren; $B N I$ is Station Bun Iba; BNM is Station Bun Mkun; TPR is Station Tapor Pandera; KFR is Station Kim Far; WBI is Station War Beki; WOR is Station War Ongkor, WMK is Station War Manak.

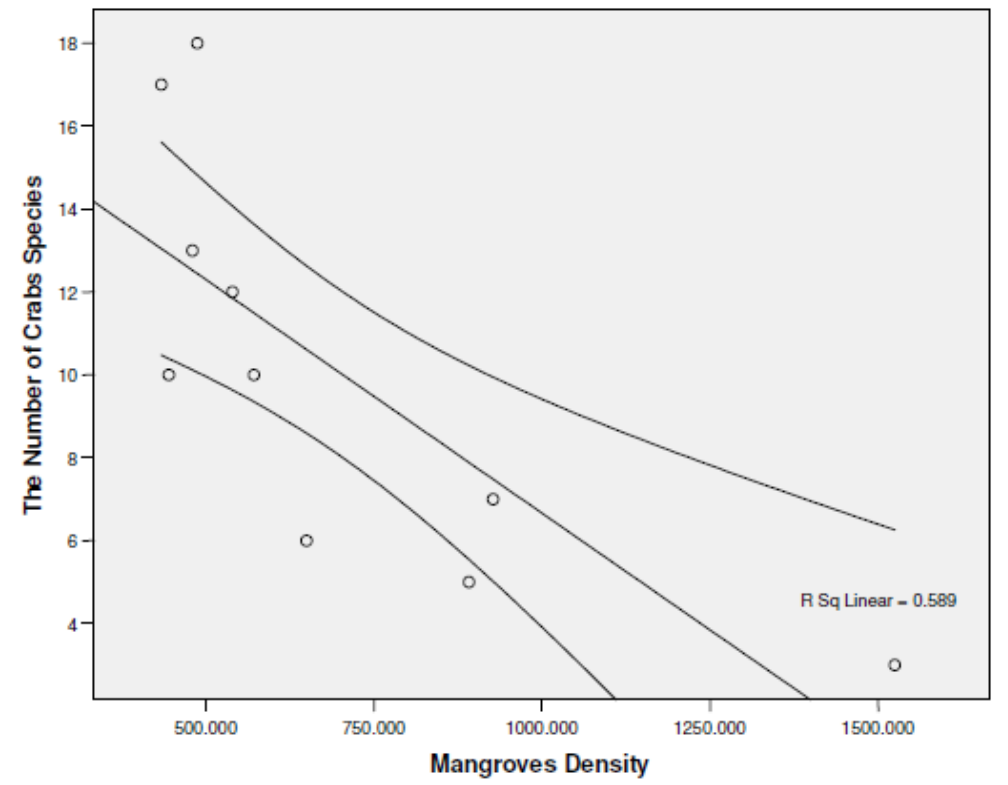

Figure 22. The Relationship between Mangrove Density and the Numbers of Species which have Interaction Ability

Notes: The numbers of crabs which have interaction ability are decrease following the mangrove density fluctuation.

The pattern of species interaction between crabs in term of sharing habitat, called the Meta population or the population of populations (Primack, 2006), because this crabs consist of many colony which attendance together in an open area or in mangrove forest with low density. Each colony is dominated in every different pieces of habitat, however they also shows a particular interactions between each 
populations. We discovered this pattern in St. Kapisawar, St. War Iprim, St. War Beren, St. War Beki, and St. Tapor Pandera. Regarding to Primack (2006) we classified the Meta population pattern of crab population in Gam Bay area in to: the simple meta-population between several small populations, meta-population with complex populations, and meta-population with a large core population and three satellite populations. Again about meta-population are still open for future research, because we have lack of information about ecological and behavioral. However, these patterns of population interactions have contribute to the relationship between mangrove density and crab community (Species Diversity and Richness), because the meta-population is connected with the habitat diversity of crabs.

b. The relationship between mangrove density and crab community (density)

The relationship between mangroves density and crab community (crab diversity, richness, and density) shows negative linear relationship (See Figure 20). Actually, density of particular organism is more connected on densitydependent factors and density-independent factors (Ricklefs, 1990; Begon, 1990; Brewer, 1994). However, the explanation about the negative linear relationship between mangroves density and crab density, little bit similar to relationship between mangrove density and crab community (crab diversity and richness), therefore see onec the chapter V. B. 3.a. The relationship between mangrove density and crab community; diversity and richness.

However, the limitation factors on this association, such as species population, size, distribution, migration, habitat diversity, food and resources, species dominances, parasitism, disease, and predations. We highlight the predation on a crab community, it will discuss here. The predation is also the main factors whic contributes to species density of crab community. This factor is a part of the density dependent factor (Brewer, 1994). We have recognized three crab as predator species, they are often appear together with Ocupodidae crabs, such as Eriphiidae ( 2 species, $3.8 \%$ of the total population of crabs species), and Ocypodidae crab are ( 1 species, $1.8 \%$ of the total population of crabs species).

The comparison between the numbers of individual on these predators' species and the total population is not equal a lot. It means the presence of predator does not have significant effect to the stability of crab population. Regarding to the habitat diversity and foods as the limited factors of crabs community, we 
presume that the habitat and food are the main factors on this relationship between mangrove density and crabs density. Whereas, the lowest density of mangroves indicated that a mangrove ecosystem consists of various crabs habitat, and the highest mangrove density specified the crab's habitat is low (See Figure 20.d). Therefore, the habitat diversity has significant effect to crab density.

\section{Mangrove Crab as the Biological Indicator for the Ecology of Mangrove Ecosystem at Gam Bay}

Whether mangrove crabs community (diversity, richnees, and density) are biological indicator of the ecology of mangrove ecosystem? This basic question is the main problems on this research. To answer this question it must be used a set of criteria species must exhibit to be considered good bioindicators (Holt \& Miller, 2011). Therefore, crabs community must be fulfilled a set of criteria below (Table 33).

Table 33. The Criteria of Biological -indicator

\begin{tabular}{|l|l|}
\hline \multirow{4}{*}{ Good indicator ability } & $\begin{array}{l}\text { Provide measurable response (sensitive to the disturbances or } \\
\text { stress but does not experience mortality or accumulate pollutants } \\
\text { directly from their environment) }\end{array}$ \\
\cline { 2 - 2 } & $\begin{array}{l}\text { Response reflects the whole population/ Community/ Ecosystem } \\
\text { response }\end{array}$ \\
\hline Abundant and common & Adequate local population density (rare species are not optimal) \\
\cline { 2 - 2 } & Common, including distribution within area of question \\
\hline Well-studied & Ecology and life history well understood \\
\cline { 2 - 2 } & Taxonomically well documented and stable \\
\cline { 2 - 2 } & Easy and cheap to survey \\
\hline Economically/ & Species already being harvested for other purposes \\
\cline { 2 - 2 } commercially & Public interest in or awareness of species \\
\hline
\end{tabular}

Adapted from Holt \& Miller (2011)

According to Ricklefs (1990), animals can control instability across their surfaces by seeking appropriate the environments, by adjusting the internal and external environment with respect to condition of surroundings. Ricklefs (1990), states:

When conditions exceed range of tolerance, organism may migrate elsewhere, rely on material stored during period of abundance or enter inactive states (for example tarpor, hibernantion, and diapauses). In many case, to respond appropriately to environment change, the individual must anticipate in condition. 
The descriptions below explain about how the mangrove crabs community will fulfill these criteria.

\section{The Criteria of Good Indicator Ability of Mangrove crabs}

a. Provide measurable response (sensitive to the disturbances or stress but does not experience mortality or accumulate pollutants directly from their environment).

The average level of disturbances at table 9, state that the entire mangroves areas in Gam Bay have low level of disturbances. The level mangrove diversity is moderate, where the total number of mangrove trees is 25 species (15 of the true mangrove species and 10 of the untrue or associated mangrove species) and 623 individual. The level of crab diversity, richness, and density are high, where the total numbers of mangrove crabs is 53 species and 2846 individual. These populations live in the mangrove ecosystem, which have low level of disturbances. It indicates the environment can be able to support all organisms or both populations under the level the carrying capacity of mangrove ecosystem in Gam Bay area, and then crab community as integrator of environmental condition. We are going to agree with this explanation, but the future research are needed, in order to compare this conclusion with other location which has high or moderate level of disturbances.

b. Response reflects the whole population/community/ ecosystem response.

This variable is comfortable with the result of all relationships among crab community and crab community (Table 34), it reasonable that crab community is fitting with this criterion. According to (Ashton et al. 2003), crab community structure and species number were positively correlated with tree and seedling community structure and diversity, suggesting that the mangrove vegetation is important for the crab as a habitat and food supply. According Primack (2006), particular area may contain critical habitat and resources is the keystone resources, then Ricklefs (1990) states the numbers of species are affected by variety of suitable habitats in particular area. Base on both statements, mangrove ecosystem is categorize as the keystone resources for mangrove crab. On the other hand mangrove crabs is the "keystone" of mangrove ecosystem itself (Nordhaus, 2003; Mazimder \& Saintilan, 2003; Gillikin, et al., 2004; Amarasinghe, 2009). According to Muehlenberg (2011), states several important roles of mangrove crabs, such as: 
1) Most important form of crab herbivory is the eating of leaves and the reproductive products of mangrove trees (destruction of propagules is significant)

2) The bigger the gap in mangrove forest, the lower the rate of seedling predation by mangrove crabs

3) Selective destruction of propagules determines the distribution pattern of tree species (affects zonation)

4) Crabs prefer decayed leaves (as leaves decay, flavolans [condensed tannins] decrease)

5) Processing of leaf litter expedites breakdown and makes this crucial energy source more readily available to other organisms

There are many theories about the relationship among species diversity and physical characteristic of particular area, for example species-area relationship, islands-mainland relationship (Begon, et. al, 1990), and then lowland-highland relationship (Ricklefs, 1990). Base on our data we have proved that mangrove crab are responsd to mangrove ecosystem, that is why mangrove crabs have very strong relationship with mangrove ecosystem. Therefore, mangrove crabs are fulfilling this condition as the bio-indicator for the ecology of mangrove ecosystem.

Table 34. The Status of The Relationship between Mangrove Community and Crab Community

\begin{tabular}{|l|l|l|}
\hline Relationships & $\begin{array}{l}\text { The status of the } \\
\text { Linear Relation }\end{array}$ & $\begin{array}{l}\text { The Status of } \\
\text { Association }\end{array}$ \\
\hline Mangrove Diversity vs Crabs diversity & Less significant & Positive linear \\
\hline Mangrove Diversity vs Crabs Richness & Less significant & Positive linear \\
\hline Mangrove Diversity vs Crabs density & Less significant & Positive linear \\
\hline Mangrove Richness vs Crabs Diversity & Significant & Positive linear \\
\hline Mangrove Richness vs Crabs Richness & Significant & Positive linear \\
\hline Mangrove Richness vs Crabs Density & Significant & Positive linear \\
\hline Mangrove Density vs Crabs Diversity & Significant & negative linear \\
\hline Mangrove Density vs Crabs Richness & Significant & negative linear \\
\hline Mangrove Density vs Crabs Density & Significant & negative linear \\
\hline
\end{tabular}

\section{The Criteria of Abundant and Common}

a. Adequate local population density (rare species are not optimal)

Mangrove crab communities in Gam have 7 families, 53 species, and 2846 individual, not all crabs species in Gam Bay have great density. There are three families with great population, such as: Ocypodidae, Sesarmidae, and 
Glyptograpsidae (Table 20), where Ocypodidae crab has two genus, Uca have 27 species, 1818 individual and Ocypode have 1 species, 2 individual. While Sesarmidae crabs have four genus, such as Parasesarma (13 species and 630 individual), Perisesarma (1 species, 185 individual), Sermatium (1 species, 1 individual), and Selatium (1 species, 1 individual). Glyptograpsidae only has one species but has great number of individual is about 156. These three families are well influences to the entire population of mangrove crab in Gam Bay. The data sugges the crab community in Gam Bay is fitting on this variable.

\section{b. Common, including distribution within area of question}

The clusters pattern, morphological characteristic, and zonation pattern of mangrove ecosystem in Gam Bay have provides various crab habitats and resources. Base on this observation, each type of crab habitats and resources in Gam Bay are attended by different crab species and density. Attendances of crab community in an area depend on the distribution ability of crab species itself and cluster of mangrove ecosystem. On the other words, the presence of crab habitats and resources in mangrove ecosystems in a region are the main factor for the attendances mangrove crabs. This is a form of the cause-affects relationship between habitat diversity/resources and crab community. There are 4 super families, 7 families, 12 genus, 53 species of crabs are distributed in entire mangrove areas of Gam Bay. Therefore we are going to accept this variable.

\section{The Criteria of Well-studied}

Many authors has successful to explain about the association among mangrove crab species and the mangrove ecosystem (Brown, 1992; Kathiresan \& Bingham, 2001; Macintosh \& Ashton 2002; Ashton, et al., 2003). Taxonomically this mangrove community is well documented and stable. Therefore, possible answer on this point is the mangrove community in Gam Bay was positively confirms the first variable and the second variables.

The last variable is easy and cheap to survey. Regarding to the experiences on this field work and data collection, we argue that, to do it would depend on the distances of the survey locations and the physical characteristic of mangrove ecosystem. The third variable on this point is more depending on the distances to the survey locations and the physical characteristic of mangrove ecosystem. 
4. The Criteria of Economically/ Commercially

Only one species has the economical and commercial values is Thalamita creanata (Latreille, 1829) or the blue swimming crab. Therefore, this species could be use to confirm this variable. The mangrove crab has receives seriously interest in particular from the scientist (Ashton, et al., 2003). But it is different for the layman, common people often interest in the economically and commercially values only. However, globally perspectives, mangrove crabs have receive much attention from the public (Kathiresan \& Bingham, 2001; Alongi, 2007). Again, we are going to accept these criteria. 


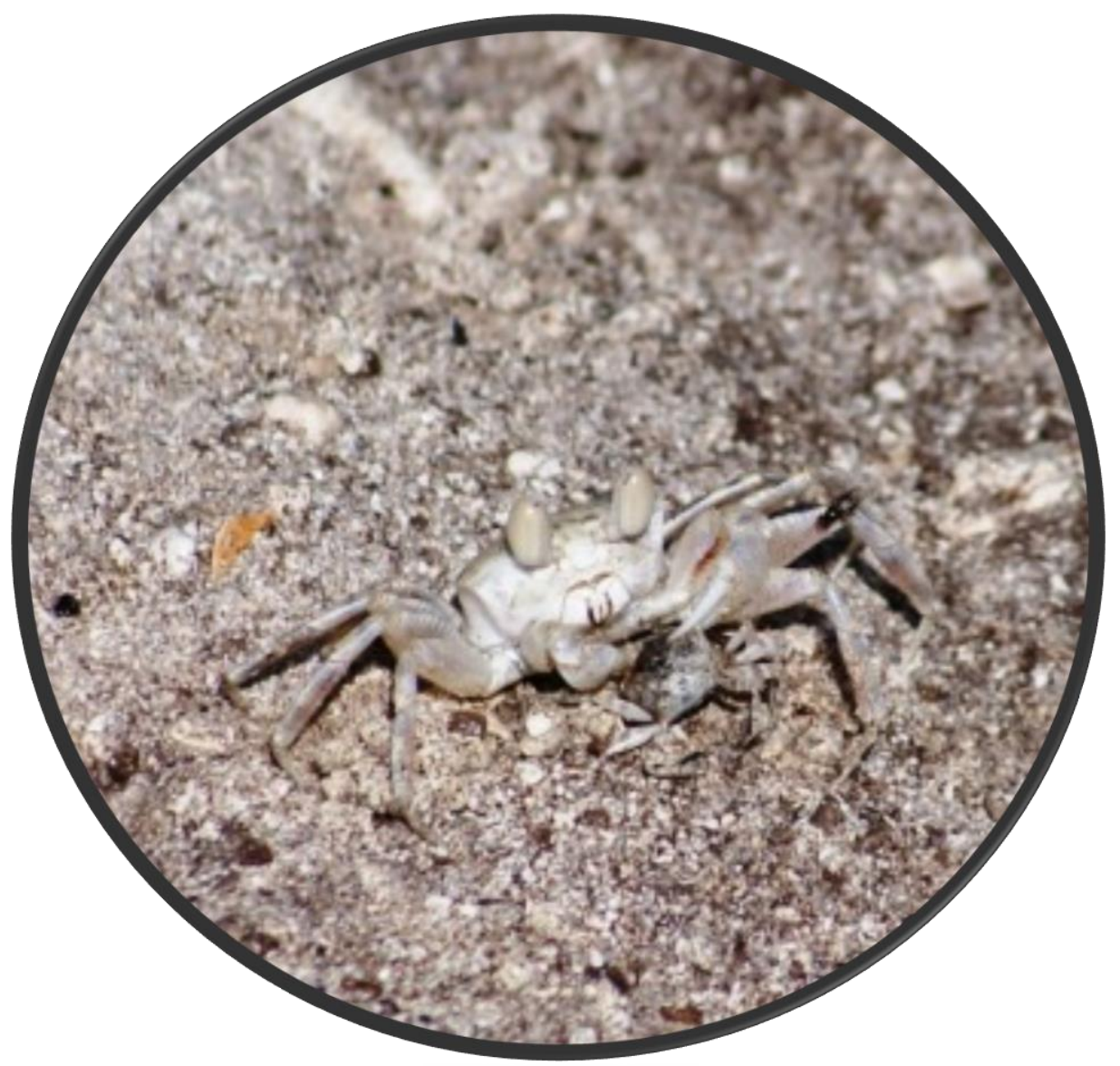

Ocypode pallidula eating Uca sp 


\section{Chapter VI. Conclusions and Recommendations}

\section{A. Conclusions}

\section{The Current Conditions of Mangrove Ecosystems in Gam Bay}

In order to examine and recognize the current conditions of mangrove ecosystems in Gam bay, therefore we use mangrove crabs as the bio-indicator, and we did an investigation at 10 locations, 40 transects, 160 sample points, and 160 quadrates. Here, we discover four clusters or types of mangrove ecosystem in Gam Bay, such as reverine mangrove ecosystems (St. War Manak \& St. War Ongkor), coves (St. War Beki, St. Kim Far, and St. Tapor Pandera), islands (St. Bun Iba and St. Bun Mkun), and coastlines cluster (St. Kapisawar, St. War Iprim, and St. War Manak).

Every type of mangrove ecosystems has exclusives ecological and biological compositions, includes mangrove trees and crabs community. There are 5 families, 9 genus, and 15 species of the true mangrove tree, the total individual is about 585. While, the associated species, we had 10 families, 10 genus, and 10 species, however $\mathrm{Sp} \mathrm{Z}$ still unknown species, and the total individual is 38 . However, Ceriops decandra is the new species for the Raja Ampat Island, therefore the total numbers of species should be change became 26 , therefore about $58 \%$ (15 from 26 species) of the true mangrove diversity in Raja Ampat are appear in Gam Bay Island. These two families have the great numbers of density among others, such as Rhizophoracea (Bruguiera: 2 species and 278 individual, Ceriops: 2 species and 37 individual, and Rhizophora: 3 species and 146 indvidual).

Here, we discover various mangrove crabs species, 4 super family such as Ocypodoidea, Eriphioidea, Grapsoidea, Ocypodoidea, Portunidae, and Grapsoidea; 7 families, such as Dotillidae, Eriphiidae, Glyptograpsidae, Macrophthalmidae, Ocypodidae, Portunoidae, and Sesarmidae, 14 genus such as Ilyoplax, Epixanthus, Myomenippe, Metopograpsus, Macrophthamus, Ocypode, Uca, Thalamita, Parasesarma, Perisesarma, Sarmatium, and Selatium; and they are 53 species and 2846 individual of mangrove crabs. Our data states, there are $41 \mathrm{crab}$ species have associated ability and 12 species does not have associated ability. We suggested the association ability as the ability to share their microhabitat, called inter-association crab species.

The data states, three predators species are present in Gam Bay area, Myomenippe sp, Epixanthus dentatus (white, 1847), Ocypode pallidula (Jacquinot, 1852), and two migratory species Thalamita creanata (Latreille, 1829) and Myomenippe sp. Those 
predator species usually present together or nearby the colony of $u c a$, while $T$. creanata often in sea grass ecosystem and Myomenippe $s p$ appear in coastland near by the mangrove ecosystem. We describes that not all crabs have the greatest density, only these crabs: Ocypodidae, Sesarmidae, and Glyptograpsidae. Where Ocypodidae: Uca have 27 species, 1818 individual and Ocypode have 1 species, 2 individual. Sesarmidae crabs: Parasesarma (13 species and 630 individual), Perisesarma (1 species, 185 individual), Sermatium (1 species, 1 individual), and Selatium (1 species, 1 individual). Glyptograpsidae only have species, but have great number of individual is about 156.

In conclusion that Gam Bay region have high mangrove crab diversity and richness, the values of Shannon-Wiener is about 4.823, Simpson index is about 0,954, and Margalef index is about 6.538. Mangrove trees diversity and richness have moderate to high values, Shannon-Wiener index is about 2.411, Simpson index is high or 0.854 , and the Margalef index 3.884.

Eventhough this region have low human population, but human activities was distressed the integrity of mangroves ecosystem. Base on the ranks of disturbances, we summarized that mangroves forest ecosystems in Gam Bay have low level of disturbances. Correlated with the biological component and the integrity of mangrove ecosystem, we verified mangrove ecosystems capable to support and provide a suitable fundamental niche for the diversity and density of mangrove crab species. Therefore, the current disturbances on mangrove ecosystems in Gam Bay are under the carrying capacity, their integrity and stability are secure from being degradation.

\section{The Relationship between Mangroves Community and Mangrove Crabs Community (Diversity, Richness, and Density)}

Our data shows that mangrove crabs communities have very strong relationship with mangroves community. We categorize two types of association between mangroves ecosystem and mangrove crabs. First the ecological relationship is the affiliation between mangrove crabs as the organism and mangroves forest as the ecosystem. Second, the biological interaction is the effects of crabs community have on the mangroves community, then oppositional the effects of mangroves on the mangrove crabs community.

The results of the linear regression analysis and Pearson's index shows, mangroves diversity and crabs community (diversity, richness, and density) positively have less significant relationship, mangrove richness and crab community positively have significant relationship, and then mangrove density and crab community 
negatively have significant relationship. Therefore we are going to reject $\mathrm{H}_{0}$ and accept $\mathrm{H}_{1}$; there is a relationship between mangrove crabs diversity and the ecology of mangrove ecosystem in Gam Bay, Raja Ampat.

The coastal mangrove ecosystems provide: high diversity and richness of mangrove trees; high diversity, richness, and density of mangrove crabs; and also high diversity of crab habitats; but these ecosystems have low mangrove density. The rivers mangrove ecosystems have high density of mangrove trees than others types of mangrove ecosystems, but these ecosystems have low diversity and richness of mangrove trees; low diversity, richness, and density of mangrove crab; and also low diversity of crab habitats. While the coves and islands mangrove ecosystems are suitable for both relationships. These correlations are cause-and-effect relationship, where mangroves community affected on mangrove crabs, and crab community affected on mangroves community.

Therefore, the high diversity, richness, density of mangarove crabs indicates a mangrove ecosystem has low density, high diversity and richness of mangrove trees, and also high diversity of crab habitats. This is appropriate for the coastline mangrove ecosystem. While, low diversity, richness, density of mangrove crabs indicates a mangrove ecosystem has high density, low diversity and richness of mangrove trees, and low crab habitat. This is suitable for the riverine mangrove ecosystem. However, the islands and the coves mangrove forests are compatible for both typical of ecological and biological correlation.

The contribution factors on these relationships, such as:

a. The types and the physical characteristics of mangroves ecosystem in Gam Bay, there are four cluster or types, such as coastline mangrove ecosystems, rivers, coves, and small islands. Our data states that the coastline mangrove ecosystem provide better fundamental niche for mangrove crabs community, therefore the great crab diversity, richness, and density are available in this type of mangrove ecosystem.

b. Habitat diversity in an ecosystem contributed to the availability of species in Gam Bay area; they are 12 various substrates, the dead stems wood, and mangrove roots system. Types of substrates such as: clay substrate, clay-muddy substrate, flat rocky substrate, gravels-sand substrate, muddy substrate, muddy-clay substrate, muddysand substrate, muddy-sand-gravels substrate, sandy substrate, sandy-gravels substrate, sandy-gravels substrate, and sandy-mud substrate. 
c. Significantly contribution of Ocypodidae and Sesarmidae as the greatest population of entire crab population in Gam Bay. Ocypodidae 28 species or 53\% and 1830 individual, Sesarmidae crabs have 17 species or $32 \%$ and 828 individual of mangrove crabs in Gam Bay area. Ocypodidae crab often feeding on the ground, living together in larges cluster, being prey for other crab predators, and need space for their daily activities. Sesarmidae crab often uses mangrove three as their habitat and feeding on it, especially Rhizophora mangroves trees, they often together with Uca spp.

d. The inter-association ability or the ability of crab species to share their micro habitat with other different species, such 27 species Ocypodidae crabs, 16 species Sesarmidae, 2 species Macrophthalmidae, 2 species Glyptograpsidae, and 2 species Metapograpsus.

e. The adaptation ability or the capability crabs species to live in different types of mangrove ecosystem or crab which is great home range. Ocypodidae is good example for this factor, for example Uca crassipes, Uca sp 12, are present at 7 different stations or $70 \%$ of entire area. While, Uca sp 02, Uca sp 20, Uca sp 21, and Uca sp 22.

f. The contribution of migratory species, migration trough two micro-habitats and two nearest ecosystems. We recognize two species as the migratory species, Thalamita creanata are often appearing in sea-grass ecosystem and Myomenippe sp. often in the coast land nearby the mangrove ecosystem. Some crabs also move from one microhabitat to another microhabitat for example Selatium spp and Metopograpsus frontalis (Miers, 1880), they are the climbing crabs which usually doing feeding activity together with Uca spp. However, this factor have less significant contribution.

g. Food and resources are also important factors for this relationship. Base on the foodweb structure we classifying crab community became, primary consumers, secondary consumers of crabs, tertiary consumers, and detritivores or decomposers. Here, we are able to categorize Ocypodidae crab (28 species or $53 \%$ of total mangrove crabs) and Glyptograpsidae crabs Eriphiidae (2 species or $3.77 \%$ ) as the decomposer species. Then, Sesarmidae crab (17 species or $32 \%$ of total crabs species) are secondary consumer and decomposer, 1 Species Dotillidae crab is Ilyoplax sp (1 species or $1.8 \%$ ) and Macrophthalmidae crabs (2 species or $3.77 \%$ ) are the decomposer species, and there are tertiary consumer or predator species such 
as, Eriphiidae (2 species or $3.8 \%$ ), and 1 Species Ocypodidae crab is Ocypode pallidula (1 species or $1.8 \%$ ). However, predator crabs have not significant affect on these relationships; because only three crab as predator species have found in Gam Bay and they have small population.

Table 35. Review the Criteria of Biological -Indicator

\begin{tabular}{|c|c|c|c|}
\hline Criteria & Sub criteria & Review & $\begin{array}{l}\text { My Personal } \\
\text { Statement }\end{array}$ \\
\hline \multirow[t]{2}{*}{$\begin{array}{l}\text { Good indicator } \\
\text { ability }\end{array}$} & $\begin{array}{l}\text { Provide measurable response (sensitive to the } \\
\text { disturbances or stress but does not experience } \\
\text { mortality or accumulate pollutants directly } \\
\text { from their environment) }\end{array}$ & Yes & $\begin{array}{l}\text { Clear, but need future } \\
\text { research to compare } \\
\text { the role of crabs } \\
\text { diversity as the } \\
\text { biological indicator in } \\
\text { a mangrove forest } \\
\text { which has high } \\
\text { disturbances and low } \\
\text { disturbances }\end{array}$ \\
\hline & $\begin{array}{l}\text { Response reflects the whole population/ } \\
\text { Community/ Ecosystem response }\end{array}$ & Yes & Clear \\
\hline \multirow[t]{2}{*}{$\begin{array}{l}\text { Abundant and } \\
\text { common }\end{array}$} & $\begin{array}{l}\text { Adequate local population density (rare } \\
\text { species are not optimal) }\end{array}$ & Yes & Clear \\
\hline & $\begin{array}{l}\text { Common, including distribution within area of } \\
\text { question }\end{array}$ & Yes & Clear \\
\hline \multirow[t]{3}{*}{ Well-studied } & Ecology and life history well understood & Yes & Clear \\
\hline & Taxonomically well documented and stable & Yes & Clear \\
\hline & Easy and cheap to survey & Yes & $\begin{array}{l}\text { Depend on the } \\
\text { distances and the main } \\
\text { problem of survey } \\
\text { itself }\end{array}$ \\
\hline \multirow[t]{2}{*}{$\begin{array}{l}\text { Economically/ } \\
\text { commercially }\end{array}$} & $\begin{array}{l}\text { Species already being harvested for other } \\
\text { purposes }\end{array}$ & Yes & $\begin{array}{l}\text { Clear, but needed to } \\
\text { compare other crabs } \\
\text { which has } \\
\text { economical and } \\
\text { commercial in } \\
\text { different type of } \\
\text { ecosystem, such as } \\
\text { mangrove ecosystem } \\
\text { and sea grass } \\
\text { ecosystem }\end{array}$ \\
\hline & Public interest in or awareness of species & Yes & Clear \\
\hline
\end{tabular}

Adapted from Holt \& Miller (2011)

\section{Mangrove Crabs as Bio-Indicator for the Ecology of Mangrove Ecosystem in Gam Bay}

Mangroves crab community (diversity, richness, and density) are appropriate as biological indicator for the ecology of mangrove forest, therefore scientists are called mangrove crab is the keystone of seashore and the ecosystem engineers of mangrove forest ecosystem. Base on this study mangrove crabs have significant relationship with the mangrove forest ecosystem and compatible for the criteria of biological indicator 
(See Table 35). Therefore crab community as the biological indicator is usefull to describe the ecological condition of particular mangrove forest area.

An assessment for the affect of human activities on mangrove ecosystem is needed a suitable crab species. Therefore we are suggesting three climbing crabs as the most dependent species such as: Selatium sp 01, Metopograpsus frontalis (Miers, 1880), and Selatium sp 02, they are the Sesarmidae crabs. Our assumption these crabs cannot life without the mangrove forest ecosystem. Therefore it is suitable for the assessment of the human impact on mangrove forest ecosystem.

\section{B. Recommendations}

\section{Recommendation for the Future Research}

a. The current condition of mangrove ecosystems shows that the environments in Gam Bay Island have capability to support both population crabs and mangrove trees under the level of the carrying capacity of mangrove ecosystems. But the future research is needed, in order to compare this conclusion with other location which has high or moderate level of disturbances.

b. Probably, there are some species as the true mangrove crabs and the migratory mangrove crabs or untrue mangrove crabs. The true mangrove crabs means mangrove crabs species are only found in mangrove forest ecosystem, for example Selatium spp and Metopograpsus frontalis (Miers, 1880), they may life without the mangrove forest ecosystem, because they are more depend to mangrove ecosystem. In order to make this conclusion became more sense, the future research is needed.

c. The patterns of population interactions are contribute to the relationship between mangrove density and crab community (Species Diversity and Richness), because the meta-population is connected with the habitat diversity of crabs. Again about meta-population of crab community is still open for future research, because we have limited information about ecological and behavioral of mangrove crabs.

d. We are categorized Ocypodidae crab (28 species or $53 \%$ of total mangrove crabs) and Glyptograpsidae crabs Eriphiidae (2 species or $3.77 \%$ ) as the decomposer species. Then, Sesarmidae crab (17 species or $32 \%$ of total crabs species) are secondary consumer and decomposer, Dotillidae (1 species or $1.8 \%)$ and Macrophthalmidae crabs (2 species or $3.77 \%$ ) are the decomposer species, and there are tertiary consumer or predator species such as, Eriphiidae ( 2 species or $3.77 \%$ ), and Ocypodidae crab are (1 species or $1.89 \%)$. Again this description is needed 
more detail information, therefore we suggest this topic for the future research about the food web structures of mangrove crabs.

e. The explanation on this relationship between mangrove diversity and crabs density is not clear yet. Eventhough, the $\mathrm{x}$ values of crab density can be predicted base on the linear regression analysis, therefore we suggesting the mangroves diversity as the indirect factors on crab density. However the future research is recommended about this relationship and should be focus on Sesarmidae crab, especially genus Parasesarma and Perisesarma. There are seven species of Sesarmidae crab in St. War Manak and War Ongkor, such as: Parasesarma sp 07 with 56 individual, Parasesarma sp 08 with 105 individual, Parasesarma sp 11 with individual, Metopograpsus frontalis (Miers, 1880) with 4 individuals, Perisesarma sp 02 with 183 individual, Selatium sp 02 with 9 individual, and Parasesarma sp 12 have 1 individual. Then the total mangroves density in St. War Onkor is 649.631 individual/ha and St. War Manak is 1524.762 individual/ha (See Table 19), and the total density of crab in St. War Manak is about 7823.19 and in St, War Ongkor is about 10641. We believe it would be significant relationship between mangrove density and Sesarmidae crab community in both areas.

f. Is there a zonation of different crab species along the flooding gradient? In order explaining this question, we needed another future research as well. Our assumptions for this porpuse we have to use the systematic transect design and vertically transect direction toward the sea. Because this design is able to collect the zonation pattern of different crabs along the flooding gradient on a mangrove ecosystem.

g. There are several groups of crabs are found in Gam Bay too, such as sea grass crabs, coral reef crabs, land crabs, and freshwater crabs. Surely each group provides enormously different crab species. It is very attractive for the future research.

h. We are promoting mangrove crab diversity as the biological indicator for ecology of mangrove ecosystem. However, we also suggest the future research should be focus on the intermediate and high level of disturbances, in order to compare this results and conclusion with the intermediate and high level of disturbances. This approach also useful to measure the human impacts on the mangrove forest ecosystem.

i. We recognize a relationship between the distances of mangrove forest toward human population is contributes to the level of disturbances. However this is the basic information for the future research. Therefore we are suggesting this topic: The 
relationship between remoteness and the ecological status of mangrove ecosystem area.

\section{Conservation Approaches: How to conserve the Crabs and Mangrove Ecosystem in Gam Bay}

a. The government agencies and conservation organization in Raja Ampat have set priorities to establishing new protected area in Gam Bay. This area is the tourism priority area and includes extensive zone, therefore establishing new protected area is recommended. Trough this protected area, we are able to protect the mangrove ecosystem and their biological components, includes mangroves crab, regarding to Primack (2006) protected area are often established to protect individual species, endangered species, keystone species, and culturally significant species.

This scenario is called the adaptive protected area (APA), which mean we not close the entire area, but we divided Gam bay area to be three zonations, such as extensive zone (totally close), intensive (very limited harvesting), and semi-intensive (limited harvesting). The main purposes for this scenario is to protect the natural resources in Gam Bay and to arrange the special zone for harvesting. The classical reasons for this scenario is about the local people, such as: (1) Gam bay is the heritages of the local peoples or Baik Betew tribe, (2) their are usual harvesting the natural resources for their daily needs, (3) they had very strong relationship with Gam bay, (4) they are more dependent to Gam Bay.

We are also suggest the procedural to establish the APA, such as: (1) do assessment of the current status of a particular mangrove forest area, (2) Created the list of priority area as the extensive zone (is better to adopt the Sasi or the Pemali area base on the traditional knowledge), intensive, and semi-intensive zone, (3) Prepare the regulation, (4) launching the ADA in Gam Bay.

b. There are no mangroves conservation areas in Raja Ampat Islands, therefore the local government have to establish the special regulation to protect the mangrove forest area. 
है

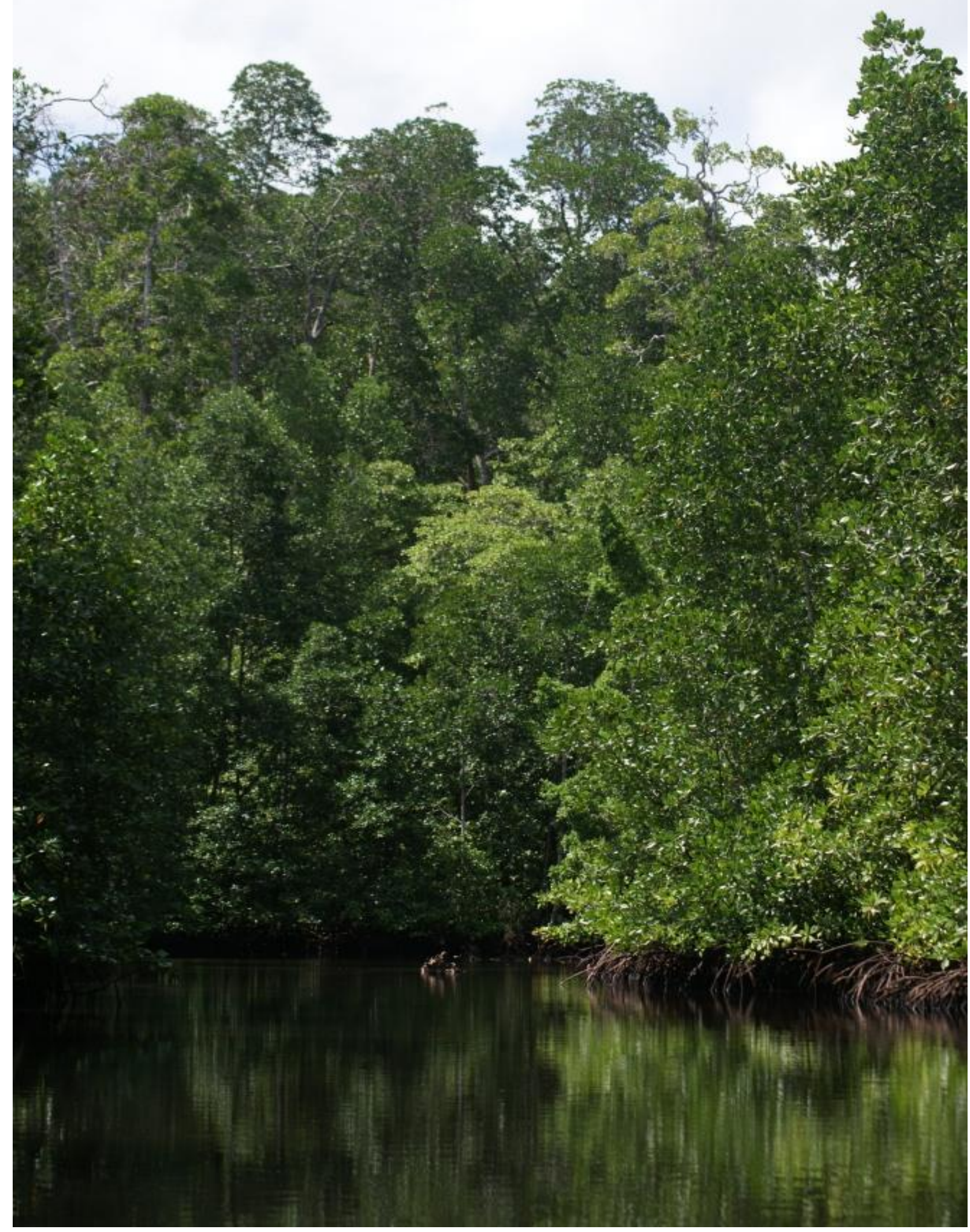

Mangrove Ecosystem at Station War Ongkor, Gam Bay 


\section{Glossary}

Associated ability

Bioturbation

Biological interaction

Carnivore

Carrying Capacity

Community

Density
Density-dependent
factors
Density-independent
factors
Ecology

Ecological relationship Ecosystem

Ecosystem health

Ecosystem integrity Ecosystem services

Entisols

Fundamental niche

Histosols

Herbivore

Limiting factor

LIPI

Inceptisols

Indicator species
: The ability of crab species to share their microhabitat or to live to gather with other different species in a micro habitat.

: The changes to the physical, chemical and biological nature of the ecosystem as a result of the presence particular organisms.

: The effects organisms in a community have on one another.

: A secondary consumer or predator is an animal species that consumes other animals to survive.

: The number of individuals an environment can support without significant negative impacts to the given organism and its environment.

: Collection of species living together with implication of strong interdependence and resulting patterns sensitive to precise combination of species present

: The number of individual per unit space.

: A factor whose effects on the size or growth of population vary with the population density.

: A factor that affects the size of a population independent or regardless of the population density.

: Relationship of a species to its biological and physical environment.

: The relationship between organisms in an ecosystem.

: An ecological unit made up of a complex system of interactions between living communities (plant, animal, fungi, and microorganisms) and the environment they live in.

: Property of an ecosystem in which all processes are functioning normally.

: The ability of an ecosystem to maintain its organization.

: The benefits people obtain from ecosystems. These includes provisioning services such foof and water; regulating services such as spiritual, recreational, and cultural benefits; and supporting services.

: Very young soil, with little or no profile except for a thin humic surface horizon. This soil occurs mainly on recent alluvium or on steep slopes where soil erosion take place, or on coastal deposits.

: The full range of environmental conditions (biological and physical) under which an organism can exist.

: Soil that contain very high levels of organic matter (peat soils). These soils are mostly dark brown to black in color, and occur in swampy areas.

: Primary consumer is species that eat plants and other photosynthetic organisms.

: A Limiting factor is somthing that limits the growth, reproduction or distribution of organisms.

: Sciences Institute of Indonesia (Indonesian: Lembaga Ilmu Pengetahuan Indonesia).

: Moderately weathered soil, with slightly developed soil horizons.

: Species used in a conservation plan to indentify and often 
Keystone species

Limiting factor

Metapopulation

Microhabitat

Mutualism

Mollisols

Mutaulistic

Pamali area/ Sasi area

Predation

Species richness

Species-area relationship

Station

Succession

Synecology

Vertisols protect a biological community or set of ecosystem process. : A single kind of organism or a small collection of different kinds of organisms that occupy a vital ecological niche in a given location.

: A Limiting factor is somthing that limits the growth, reproduction or distribution of organisms.

A regional population consisting as a number of spatially discrete subpopulations distributed among habitat fragments and connected via dispersal.

: The smallest part of the environment that supports a distinct flora and fauna

: Association between organisms of different species that is essential for, or significantly improves, their survival and vitality.

: Soil in which there is accumulation and decomposition of organic matter.

: Refers to an interaction between two or more distinct biological species in which members benefit from the association. Describes both symbiotic mutualism (a relationship requiring an intimate association of species in which none can carry out the same functions alone) and nonsymbiotic mutualism (a relationship between organisms that is of benefit but is not obligatory: that is, the organisms are capable of independent existence).

The traditional protected area base on the indigenous knowledge of Biak Betew Tribes of Raja Ampat.

: Act of killing and consuming another organism for food.

: A type of approach to assessing biodiversity that examines the distribution of all resident terrestrial vertebrates: amphibians, reptiles, birds, and mammals.

Number of species found in an area increase with the size of the area; i.e., more species are found on large island than small islands.

: The single research station.

: The change in numbers and kinds of organism leading to a stable (climax) community, replacement of communities, one by another, on an area.

: The study of groups of organisms which are associated together as a unit.

: Soil with high montmorillonite clay content those are sticky when wet and very hard when dry. 


\section{Acknowledgments}

The greatest thanks addressed to my Lord Jesus for answering my requests regarding to the thesis project and for everything in my life. I would like to acknowledge the Cenderawasih University, the MINC Program of both Gottingen University-Germany and Lincoln University, the Directorate General of Higher Education Ministry of National Education Indonesia (DIKTI) for the scholarship since August 2008- August 2010.

Here, I would like to thanks and shows truthful appreciation to Prof. B. Kambuaya as the Rector of Cenderawasih University; he had provides permission and recommendation to continue this postgraduate study. To Prof. M. Muehlenberg, as my supervisor and lecturer, I was receives a lot kindness and advises from him, I'm able study at the MINC program because of him. Prof. Daniel Jackson, at that time too difficult to found the examiner, and finally he accepted the request as the examiner. Mr. Sam Renyaan, as the senior lecturer at Biology Department of Cenderawasih University, he gives guidances and supports to me along my studies. Michaela Duetinger, she is very good person, she always give many important advices and information's to me. I would like to show my thankfulness to my teachers from both universities, Prof. Dr. Christoph Kleinn, Dr. Matthias Waltert, Dr. Stephen Espiner, Dr Shaun C. Ogilvie, Dr. James Ross, Dr. Jon. J. Sullivan, Dr. Laura E. Molles. Dr. Adrian M. Paterson, and Prof. Dr. Charles Eason.

The special thanks also to Paulus Sawiyai, Salma Mayor, Heji Dimara, Metu Dimara, Nikolas Sawiyai, Kalvin Ronsumbre, Bertha Ronsumbre, Esther Mayor, there are very nice people, who are working together with me in Gam Bay. Peoples at Sawainggrai and Kapisawar villages, without questions they accepted and allowed me to do my research in Gam Bay area. The special thanks to my mother Hellena Kalorbobir/R, my young brother Dehir P. Kalorbobir and Yohan Mensiani, my nephew Estevany Rosye Gaspers. To my class mates, Alice Mercier, Anna Reuleaux, Andrea Höing, Carmen Gischke, Christoph Rehse, Flora Mueller, and Haojin Tan. Many thanks also to Ibu M. Flassy, Ibu H. Keiluhu, Ibu H. Ohee, Ibu Konni, Ibu Dawiaa, Evie L. Warikar, and Erlani Rahareng. 


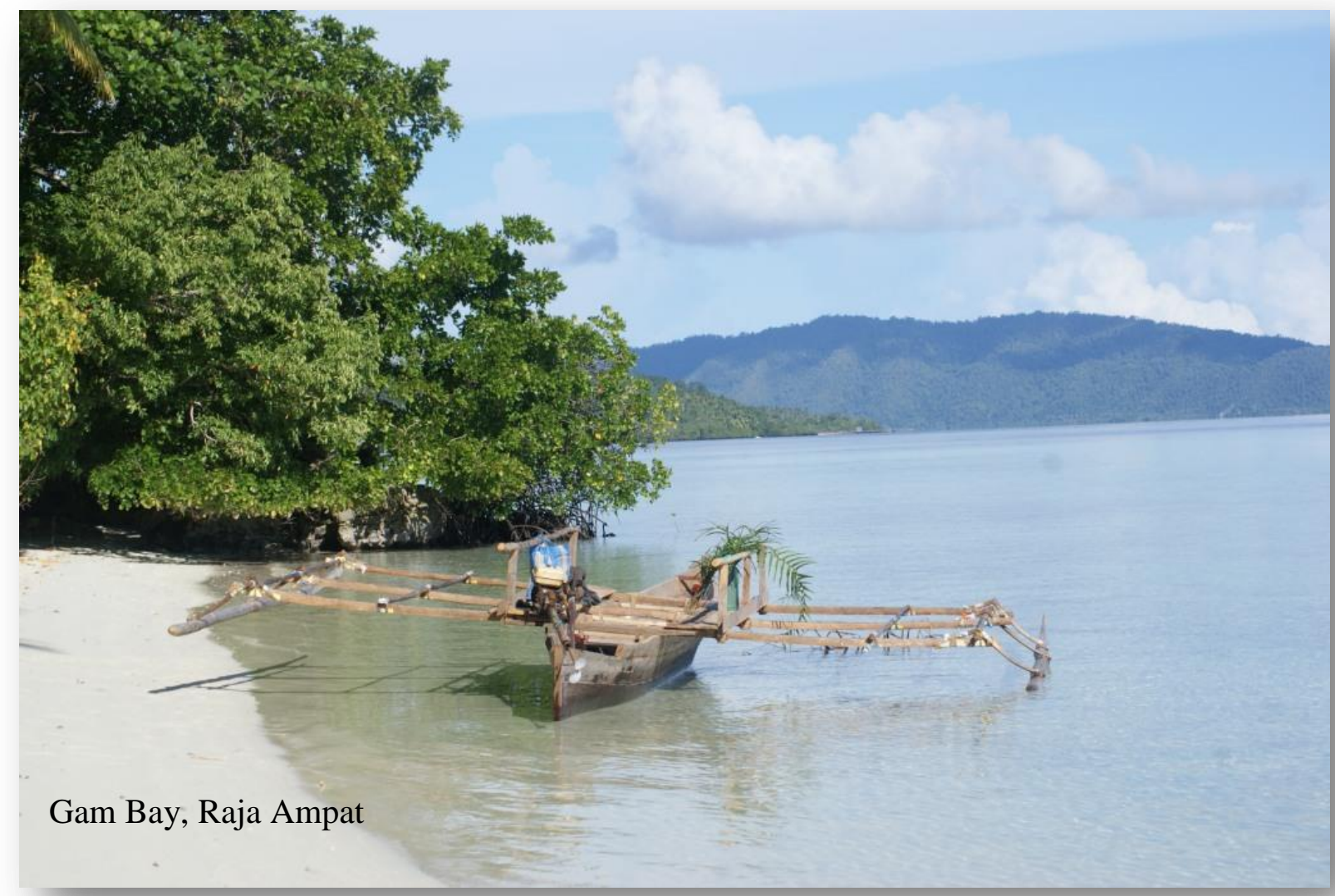




\section{Bibliography}

Ahyong, S. T. \& Ng, P. K. L. (2009) The Cymonomidae of the Philippines (Crustacea: Decapoda: Brachyura), with of Zoology, 20: 233-246. Descriptions of Four New Species. The Raffeles Bulletin.

Ainsworth, C. H., Varkey, D. A., \& Pitcher, T. J. (2008) Chapter 1. Ecosystem Simulation Models of Raja Ampat, Indonesia, in Support of Ecosystem Based Fisheries Management. Bailey, M. \& Pitcher, T. J. (Eds). Ecological and Economic Analyses of Marine Ecosystems in the Bird's head Seascape, Papua, Indonesia: II. Fisheries Centre Research Report. University of British Colombia, Canada. Vol. 16.1: 3-52.

Akil, J. M. \& Jiddawi, N. S. (1997) A Preliminary Observation of the Flora and Fauna of Jozani-Pete Mangrove Creek, Zanzibar, Tanzania.

Allen, G. R. \& Erdmann, M. V. (2009) List of Species: Reef Fishes of the Bird's Head Peninsula, West Papua, Indonesia. Check List 5. 3: 587-628.

Alongi, D. M. (2007) Mangrove Forest of Papua, in Marshall, A. J., \& Beehler, B. M.(Eds) The Ecology of Papua: Part One (Vol. 4: 824-857), Periplus Editions (HK), Singapore.

Amarasighe, M. (2009) Mangrove crabs: the ecosystem engineers and keystone species, posted on 28 October 2009, accessed at 4 October 2011

Ashton, E. C., Macintosh, D. J., \& Hogarth P. J. (2003) A Baseline study of the diversity and community ecology of crabs and mollusca macrofaunca in Sematan Mangrove forest. Sarawak, Malaysia. Journal of tropical ecology.

Badan Perencanaan Pembangunan Daerah Kabupaten Raja Ampat (BAPPEDA Kab Raja Ampat), (2010) Draft Rencana Tata Ruang Wilayah Kabupaten Raja Ampat 20102013: Laporan Akhir Tahun 2012. [Development and Planning Agency or Raja Ampat Regency (BAPPEDA Kab. Raja Amapat).(2010) The Regional Master Plan of Raja Ampat Regency 2010-2013: The Annual Report 2012 ] PT. Genta Prima.

Bailey, M. (2003) Economic analysis of Unregulated and Illegal fishing in Raja Ampat, Indonesia. (Master's Thesis) The University of Western Ontario. UK.

Barnes, B. V., Zak, D. R., Denton, S. R., \& Spurr, S. H. (1997) Forest Ecology, Forth Edition. John Wiley \& Sons, inc. USA.

Begon, M., Harper, J. L., \& Townsend, C. R. (1990) Ecology: Individual, Populations, and Cummunities. Second Edition. Blackwell Scientific Publications, London, England.

Bonine, K. M., Bjorkstedt, E. P., Ewel, K. C., \& Palik, M. (2008) Population characteristics of the mangrove crab Scylla serrata (Decapoda: Portunidae) in Kosrae, Federated State 
of Micronesia: Effects of Harvest and Implocation for Management. Pasific Science, Vol. 62.1:1-19.

Buckland, S. T., Anderson, D. R., Burnham, K. P., \& Laake, J. L. (1993). Distance sampling: Estimating Abundance of Biological Populations. London, UK: Chapman and Hall .

Buckland, S. T. , Anderson, D. R., Burnham, K. P., \& Laake, J. L. (2001). Introduction to distance sampling: Estimating abundance of biological populations. Oxford, UK: Oxford University Press.

Buckland, S. T. , Summers, R. W., Borchers, L. D., \& Thomas, L. (2006). Methodological Insights. Point Transecr Sampling with Traps or Lures. Journal of Applied Ecology. Vol. 43: 377-384

Brewer, R. (1994) The Science of Ecology, Second Edition. Sounders College Publishing. USA.

Brown, I. W. (1992) Mangrove Crabs, Pasific Islands Forum Fisheries Agency (FFA)

Conservation International Indonesia (CII), (2010). Atlas Sumberdaya Pesisir Kabupaten Raja Ampat Provinsi Papua Barat, [The Atlas of Seashore Resources in Raja Ampat Regency, West papua Province].

Campos, E. (2009). A New Species and Two New Genera of Pinnotherid Crabs the Northeastern Pacific Ocean, With A Reappraisal of the Subfamily Pinnotherinae de Haan, 1833 (Crustacea: Brachyura: Pinnotheridae). Zootaxa, 2022: 29-44.

Collins, J. S. H., Mitchell, S. F., \& Donovan, S. K. (2009). A Nes Species of Land Crab, Sesarma Say, 1817. (Decapoda, Brachyura), from the Pleitocene of Jamaica. Scripta Geologica, Leiden. 138: 11-21,

Echeverria-Saenz, S., Vargas, R. \& Wehrtmann, I. S. (2003) Diversity of Decapods inhabiting the Largest Mangrove System of Pacific Costa Rica. Nauplius, 11 (2): 91- 97.

Elzinga, C.L., Salzer, D.W. \& Willoughby, J.W. (1998). Measuring and Monitoring Plant Populations. Technical Reference 1730-1. Bureau of Land Management. Denver, Colorado. USDI, BLM Fachrul, M. F. (2007) Metode Sampling Bioekologi, Bumi Aksara, Jakarta.

Faber-Langendoen, D., Rocchio, J., Schafale, M., Nordman, C., Pyne, M., Teague, J., Foti, T., \& Comer, P. (2006) Ecological Integrity Assessment and Performance Measures for Wetland Mitigation. NatureServe, Arlington, Virginia.

FAO (2007) The worlds mangroves 1980-2005. FAO Forestry paper 153. Rome. 
Fratini, S., Vannini, M., Cannicci, S., \& Schubart, C. D. (2005) Tree-climbing Mangrove Crabs: A Case of Convergent Evolution. Evolutionary Ecology Research, 7: 219233.

Galil, B. S. and Ng, P. K. L. (2010) On A Collection of Calappoid and Leucosioid Crabs (Decapoda, Brachyura) From Vanuatu, with Description of a New Species of Leucosiidae. Koninklijke NV Brill NV, Leiden. Studies on Brachyura: 139- 152

Geisen, W., Wulffraat, S., Zieren, M., \& Scholten, L. (2007) Mangrove Guide for Southeast Asia. FAO Regional Office for Asia and the Pacific Maliwan Mansion

Gillikin, D. P. \& Schubart C.D. (2004) Ecology and systematics of mangrove crabs of the genus Perisesarma (Crustacea: Brachyura: Sesarnudae) From East Africa. Zoological Jurnal of the Linnean Society, 141: 435- 445.

Gillikin, D. P., Wachter, D. B., \& Tack, J. F. (2004) Physiological Response of Two Ecologically Important Kenyan Mangrove Crabs Exposed to Altered Salinity Regimes. Journal of Experimental Marine Biology and Ecology, 30: 93- 109.

Gillikin, D. P. \& Kamanu C. P. (2005) Burrowing in the East African Mangrove Crab, Chiromantes ortmanni (CROSNIER, 1965) (Decapoda, Brachyura, Sesarnudae) . Crustaceana, 78.10: 1273- 1275.

Giri, C., Ochieng, E., Tieszen, L. L., Zhu, Z., Singh, A., Loveland, T., Masek, J., \& Duke, N. (2010) Status and Distribution of the World using Earth Observation Satellite Data. Global Ecology and Biogeography, Blackwell Publishing Ltd. 1-6.

Gray, M. J. (__ FWF 410. Area, Distance and Plotless Sampling, the lecturer material, College of Agricultural Science and Natural Resources, University of Tennessee, Knoxville.

Hsi-Te Shih \& Jhy-Yun Shy (2009), Geothelphusa makatao sp. Nov. (Crustcea: Brachyura: Patomidae), a new freshwater crab from an uplifted Pleistocene reef in Taiwan. Zootaxa, 2106: 51- 60 .

Hsi-Te Shih \& Peter K. L. NG (2011) Diversity and biogeography of freshwater crabs (Crustacea: Brachyura: Potamidae, Gecarcinucidae) from East Asia, Systematics and Biodiversity, 9:1, 1-16.

Holt, A. E. \& Miller, S. W. (2011) Bioindicators: Using Organisms to Measure Environmental Impact. Nature Education Knowledge, 2.2: 1-8

Jiang Wei \& Liu Ruiyu. (2011a) New species and new records of pinnotherid crabs (Crustacea: Decapoda: Brachyura) from the Yellow Sea. Zooloischer Anzeiger - A Journal of Comaparative Zoology. Vol 250. 4 : 488-496. 
Jiang Wei \& Liu Ruiyu. (2011b) On A New Species of Paragoneplax Castro (Crustacea: Decapoda: Goneplacidae, P. chenae sp. nov. from the South China Sea. Chinese Journal of Oceanology and Limnology, Vol. 29.1: 213-216.

Johnson, R. A. \& Bhattacharyya, G. K. (1996) Statistics: Principles and Methods. John Wiley and Sons. New York. USA

Jorgensen, S.E., Costanza, R. \& Fu-Liu Xu (edited) (2005) Handbook of ecological indicators for assessment of ecosystem health, CRC Press.

Kangas A, \& Maltamo, M (edited) (2006) Forest Inventory Methodology and Applications. Springer. Nederland.

Kathiresan, K. \& Bingham, B. L. (2001) Biology of Mangrove and Mangrove Ecosystem. Advances in Marine Biology. Vol. 40: 81-251.

Kleinn, C. \& Vilcko, F. (2006a) A new empirical approach for estimation in k-tree sampling. Institute of Forest Management, Faculty of Forest Sciences and Forest Ecology, Georg-August-University of Goettingen, Germany.

Kleinn, C. \& Vilcko, F. (2006b) Design-unbiased estimation for point-to-tree distance Sampling. Institute of Forest Management, Faculty of Forest Sciences and Forest Ecology, Georg-August-University of Goettingen, Germany.

Kleinn C. (2007). Forest Inventory. Lecture Notes for the teaching module. Institute of Forest Management Faculty of Forest Sciences and Forest Ecology. Georg August University of Goettingen, Germany.

Koch, V., Wolff, M., \& Diele, K. (2005) Comparative Population Dynamics of Four Fiddler Crabs (Ocypodidae, Genus Uca) from a North Brazilian Mangrove Ecosystem. Marine Ecology Progress Series, 291: 177- 188.

Komai, T. \& Wada, K. (2008) A Revision of the Estuarine Crab Genus Ilyopgrapsus Barnard, 1955 (Crustacea: Decapoda: Brachyura: Macrophthalmidae), with descriptions of A New Genus and One New Species. The Raffeles Bulletin of Zoology, 56.2: 357-384.

Komatsu, H \& Takeda, M. (2009a). A New Species of the Genus Pinnixa (Decapoda: Brachyura: Pinnotheridae) from Otsuchi bay, Northeastern Japan. Bull. Natl. Mus. Nat. Sci., Ser. A, Suppl. 3: 199-204.

Komatsu, H \& Takeda, M. (2009b). Rare Crabs (Crustacea, Decapoda, Brachyura) from Okinawa Island, with Description of a New Species of the Family Leucosiidae. Bull. Natl. Mus. Nat. Sci., Ser. A, Suppl. 35. 2: 125-236. 
Krebs, C. J., (1985) Ecology: The Experimental analysis of distribution and abudance, Third Edition. Harper \& Row, Publisher, Inc.

Lee, Y. S. (1989). The Importance of Sesarminae Crabs Chiromanthes spp. and Inundation Frequency on Mangrove (Kandelia Candel L. Druce) Leaf Litter Turnover in a Hong Kong Tidal Shrimp Pond. J.Exp. Mar. Biol.Ecol. Vol. 131: 23-43.

Macintosh, D. J. \& Ashton, E. C. (2002) A Review of Mangrove Biodiversity Conservation and Management. Centre for Tropical Ecosystem Research, University of Aarhus, Denmark.

Macintosh, D. J. \& Ashton, E. C., \& Havanon, S. (2002) Mangrove Rehabilitation and Intertidal Biodiversity: a Study in the Ranong Mangrove Ecosystem, Thailand. Estuarine, Coastal and Shelf Science, Vol. 55: 331-345.

Magurran, A. E. (1983) Ecological Diversity and Its Measurement. Royal Society, University Research Fellow University College of North Wales, Bangor. Croom Helm Limited.

Magurran, A. E. (1988) Ecological Diversity and Its Measurement. Princeton University Press. Princeton, New Jersey, USA.

Magnussen, S., Kleinn, C., \& Picard, N. (2007) Two New Density Estimators for Distance Sampling. Eur J Forest Rs. 127: 213-224

Mangel, M. (2006) The Theoretical Biologist' Toolbox: Quatitative Methods for Ecology and Evolutionary Biology. Cambridge University Press.

Marshall, A. J., \& Beehler, B. M. (2007). The Ecology of Papua, Part One. Conservation International Foundation, Periplus Eddition (HK), Singapore.

Maurer, B. A. (1992) Biological Diversity, Ecological Integrity, and Neotropical Migrants: New Prespectives for Wildlife Management. General Technical Report (RM)

Mazimder, D. \& Saintilan, N. (2003) A Comparison of Sampling Techniques in the Assessment of Burrowing Crab Abudance in Saltmarsh and Mangrove Environments. Wetlands, Australia, 21 (1): 1-12

McIvor, C. C. \& Smith III, T. J. (1995) Differences in the Crabs Fauna of Mangrove Areas at a Southwest Florida and a Northeast Australia Location: Implication for leaf litter processing. Estuaries, Vol. 18. 4: 591-597.

McCarthy, M. A. (2007) Bayesian Methods for Ecology. Cambridga University Press.

McLeod, E., Brian, S. \& Rodney, S. (2009). Sasi and Marine Conservation in Raja Ampat, Indonesia, Coastal Management, 37: 6, 656-676. 
McKenna, S. A., Allen, G. R., \& Suryadi, S. (Eds.). (2002). A Marine Rapid Assesment of the Raja Ampat Island, Papua Province, Idonesia. RAP Bulletin of Biological Assessment 22. Conservation International, Washington, DC.

Mendoza, J. C. E. \& Naruse, T. (2009) A new species of Macrophthalmus desmarest, 1823 (Crustacea: Decapoda: Bracyura: Macrophthalmidae) from Bohol Island, the Philipenes. The Raffles Bulletin of Zoology, 57.2: 475- 480.

Mendoza, J. C. E. \& Naruse, T. (2010) A new species of the Genus Sundathelphusa Bott, 1969 (Crustacea: Brachyura: Gecarcinucidae) from Northeastern Luzon, Philippines. Philippine Journal of Science, 139. 1: 61-70.

Mitchell Micheli, F., Gherardi, F., \& Vannini, M. (1991) Feeding and Burrowing Ecology of two East African Crabs. Marine Biology, 111: 147- 254.

Mühlenberg, M. (2011) Mangroves, (The Lecturer Material). Depertement Conservation Biology, University of Goettingen, Germany

Naderloo, R., Türkay, M., \& Hui-Lian Chen. (2010) Taxanomic revision of the wide-front fiddler crabs of the Uca lacteal group (Crustacea: Decapoda: Brachyura:Ocypodidae) in the Indo-West Pacific.

Naruse, T., \& Ng, P. K. L. (2008) A New Species of Chiromantes s. str. (Decpoda: Brachyura: Sesarmidae) from Ryuku Islands, Japan with a Note onn the Identity of Holometopus sereneis Soh, 1978.

Nature Conservancy- Southeast Asia Center for Marine Protected Areas. (2003). Report on a rapid ecological assessment of the Raja Ampat Islands, Papua, Eastern Indonesia, held October 30 - November 22, 2002. Nature Conservancy- Southeast Asia Center for Marine Protected Areas.

Ng, P. K. L., (1998) Crabs: FAO species identification guide for fishery purposes. The living marine resources of the Western Central Pacific. Cephalopods, crustaceans, holothurians and sharks. Carpenter, K.E.; Niem, V.H. (eds). Rome, FAO. Vol 2: 1046- 1155 .

Ng, P. K. L., Guinot, D., \& Davie, P. J. F. (2008) Systema Brachyurorum: Part I. An Annotated Checklist of Extant Brachyuran Crabs of the World. The Raffeles Bulletin of Zoology, 17: 1-286.

Ng, P. K. L., \& Naruse, T. (2009) On the Identity of Pinnix Brevipes H. Milne Edwards, 1853, and A New Species of Aphanodactylus Tesch, 1918 (Crustacea: Decapoda, Brachyura: Pinnotheroidea) from the Philippines. The Raffeles Bulletin of Zoology, 20: $283-290$. 
Noor, R. Y., Khazali, M., \& Suryadiputra, I. N. N. (2006) Paduan Pengenalan Mangrove di Indonesia, PHKA/WI-IP, Bogor. [A Field Guide of Indonesia Mangrove], Adapted from Geisen, W., Stephan, Wulffraat, Schoelten, Z. \& L. (__ A Field Guide of Indonesia Mangrove, WI-IP.

Nordhaus, I. (2003) Feeding Ecology of the semi-terrestrial crab Ucides cordatus ( Decapoda: Brachyura) in a Mangrove Forest in Northern Brazil (Dissertation). Zentrum für Marine Tropenökologie (ZMT), Universität Bremen.

Nordhaus, I., Wolff, M., \& Diele, K. (2006) Litter Processing and Population Food Intake of the Mangrove Crab Ucides cordatus in a High Intertidal Forest in Northern Brazil. Elsevier.

Odum, E. P. (1971) Fundamentals of Ecology, Third Eddition. W. B. Suanders Company, London, UK

Pan-Wan Hsueh, Jung-Fu Huang, \& Ng, P. K. L. (2009) On a New Genus and New Species of Pilumnid Crab from Taiwan, and the Generic Placements of Heteropanope changensis (Ratbun, 1909) and Pilumnopeus pereiodontus Davie and Gahni, 1993. Journal of Natural History, Vol. 43, Nos. 5-6: 323- 334.

Primack B. R. (2006) Essential of Conservation Biology, Fourt Edition. Sinauer Associates, Inc. Publisher. Massachusetts, USA.

Rahayu, D. L. \& Setyadi, G. (2009) Mangrove Estuary Crabs of the Mimika Region- Papua, Indonesia. PT Freeport Indonesia. Timika, Papua.

Rangka, N. A. (2007) Status Usaha Kepiting Bakau ditinjau dari Aspek Peluang dan Prospeknya. [The Marketable Status base on the Opportunity and Prospect of Mangrove Crabs]. Neptunus, Vol 14. 1: 90- 100.

Ravichandran, S., Anthonisamy, A., Kannupandi, T., \& Balasubramanian, T. (2007) Leaf Choice of Herbivorous Mangrove Crabs. Research Journal of Environmental Sciences I, 1: 26-30.

Ricklefs, R. E. (1990) Ecology, Third Edition. W. H. Freeman and Company, New York, USA.

Robertson, A. I. (1986) Leaf-burying Crabs: Their Influence on Energy Flow and Export from Mixed Mangrove Forest (Rhizopora spp.) in Northeastern Australia. Elsevier Publisher B.V. (Biomedical Division).

Schlacher, T. A., de Jager, R., Nielsen, T. (2011). Vegetation and Ghost Crabs in Coastal dunes as Indicators of Putative Stressors from Tourism. Ecological Indicator 11: 284294. 
Schwamborn, R., Ekau, W., Voss, M., \& Saint- Paul, U., (2002) How Important are mangroves as a carbon source for decapods crustacean larvae in a tropical estuary? Mar Ecol Prog Ser, 229: 195-205.

Schweitzer E. C., \& Feldmann, R. M. (2009a) New species of Longodromitidae Schweitzer and Feldmann, 2009, from the Ernstbrunn Formation, Late Jurassic (Tithonian), Austria. Ann. Naturhist. Mus. Wien, 111A: 207- 224.

Schweitzer E. C., \& Feldmann, R. M. (2009b) Revision of the Prosoponae sensu Glaessner, 1969 (Crustacea: Decapoda: Brachyura) Including Four New Families, Four New Genera, and Five New Species. Austria. Ann. Naturhist. Mus. Wien. 111A: 55- 121.

Soundarapandian, P., Samuel, J. N., Ravichandran, \& Kannupandi, T., (2008) Biodiversity of Crabs in Pichavaram Mangrove Environment, South East Coast of India. International Journal of Zoological Research. Vol: 4. 2: 113-118.

Stiling, P. D. (1992) Ecology: Theories and Application. Second Edition. Prentice Hall International, Inc.

Suryani, M. (2006). Ecology Mud Crab (Scylla serrate Forskal) in Mangrove Ecosystem in Enggano Island Bengkulu Province. (Master Thesis) The Postgraduate Program of Diponegoro University, Semarang, Indonesia.

Taylor, M., Ravilious, C., \& Green, E. P. (2003) Mangroves of East Africa. UNEP (United Nations Environment Programme)- WCMC (World Conservation Monitoring Center)

Thomas, L., Buckland S. T., Burnham, K. P., Anderson, D. R., Laake, J. L., Borchers, D. L. \& Strindberg, S. (2002) Distance Sampling. Encyclopedia of Environ metrics. Vol. 1: 544-552. El-Shaarawi A. H and Piegorsch, W. W. (Editor) @ John Wiley \& Sons, Ltd, Chichester.

Thongtham, N. \& Kristensen, E. (2003) Physical and Chemical Characteristics of Mangrove Crab (Neoepisesarma versicolor) Burrows in the Bangrong Mangrove Forest, Phuket, Thailand, with Emphasis on Behavioural Response to changing environmental conditions. Vie Milieu, 53 (4): 141-151

Turner, R. K., Subak, S., \& Adger, W. N. (1996) Pressures, Trends, and Impacts in Coastal Zones: Interactions between Socioeconomic and Natural Systems. Springer-Verlag. New York Inc. Environmental Management, 20, 2: 158-173.

Varela, C. \& Schweitzer, C. E. (2011). A New Genus and New Species of Portunidae Rafinesque, 1815 (Decapoda, Brachyura) from the Colon Formation, Cuba. Bulletin of the Mizunami Fossil Museum, 37: 13-16. 
Veron, J.E.N. \& Turak, E. (2006). Coral Diversity. In: Green, A., P. Lokani, W. Atu, P. Ramohia, P. Thomas and J. Almany (eds). 2006. Solomon Islands marine assessment: Technical report of survey conducted May 13 to June 17, 2004. TNC Pacific Island Countries Report No 1/06.

Vinay P. Padate, Chandrashekher U. Rivonker, A. Chandrashekar Anil, Subhash S. Sawant \& Venkat Krishnamurthy (2010): A new species of portunid crab of the genus Charybdis (De Haan, 1833) (Crustacea: Decapoda: Brachyura) from Goa, India, Marine Biology Research, 6.6: 579-590.

Wells, F. E. (2007) Marine Invertebrates of Papua, in Marshall, A. J., \& Beehler, B. M. (Eds) The Ecology of Papua: Part One , Periplus Editions (HK), Singapore, Vol. 4: 506507.

FAO, (2003) Status and Trends in Mangrove Area Extent Worldwide. By Wilkie, M. L. \& Fortuna, S. Forest Resources Assessment Working Paper No. 63. Forest Resources Division. FAO, Rome. (Unpublished)

Wowor, D. \& Ng, P. K. L. (2009). Two New Species of Sesarmid Crabs (Crustacean: Decapoda: Bracyura) Associated with limestone formation in West Papua, Indonesia. Zootaxa, 2025: 21- 31 . 


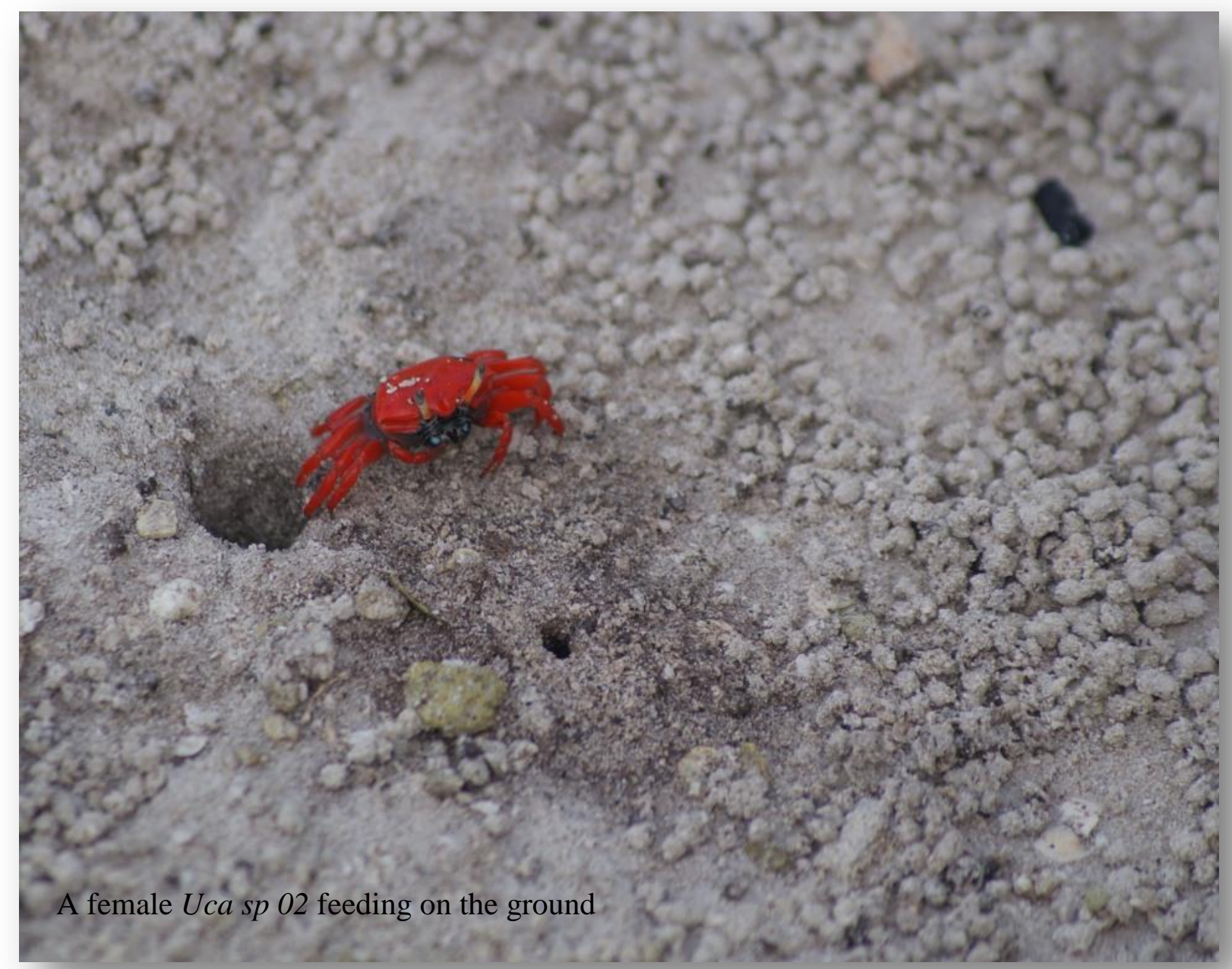




\section{Declaration}

Hiermit versichere ich gemäß $§ 9$ Abs. 5 der Prüfungsordnung für den integrierten binationalen Master-Studiengang Internationaler Naturschutz (engl.: International Nature Conservation) vom 16.08.2006, dass ich die vorliegende Arbeit selbstständig verfasst und keine anderen als die angegebenen Hilfsmittel verwendet habe. Diese Arbeit wurde nicht in der gleichen oder einer ähnlichen Form bereits einem anderen Prüfungsausschuss vorgelegt und wurde bisher noch nicht veröffentlicht.

Hereby I affirm - according to $\S 9$ section 5 of the examination regulations for the integrated bi-national Master programme International Nature Conservation (deutsch: Internationaler Natur-schutz) from 16.08.2006 - that I have penned the present thesis autonomously and that I did not use any other resources than those specified above. This work was not submitted previously in same or similar form to another examination committee and was not yet published.

Langgur, 16 July 1979

John Dominggus Kalor

Ort/ Place, Datum/Date

Name/ name 


\section{Appendixes}

1. The Time Scedules

a. Time Schedules of Thesis Project

\begin{tabular}{|c|c|c|c|c|c|c|c|c|c|c|}
\hline \multirow{2}{*}{ Activities } & \multicolumn{7}{|c|}{2011} & \multicolumn{3}{|c|}{2012} \\
\hline & 05 & 06 & 07 & 08 & 10 & 11 & 12 & 01 & 02 & $\mathbf{0 3}$ \\
\hline \multicolumn{11}{|c|}{ Field works } \\
\hline \multicolumn{11}{|c|}{ Entering data } \\
\hline \multicolumn{11}{|c|}{$\begin{array}{l}\text { Crabs and mangrove } \\
\text { Identification }\end{array}$} \\
\hline \multicolumn{11}{|c|}{ Data analysis } \\
\hline \multicolumn{11}{|c|}{ Writing thesis and consultations } \\
\hline \multicolumn{11}{|l|}{ Submitted } \\
\hline Locations & Raja & ipat & Jaya & $\mathrm{i}-\mathrm{Pa}$ & & & & & & \\
\hline
\end{tabular}

\section{b. Time Schedules of Field Work}

\begin{tabular}{|c|c|c|c|c|c|c|}
\hline Dates & Activities & $\begin{array}{l}\text { Low/high } \\
\text { Tides }\end{array}$ & Stations & Location & $\begin{array}{l}\text { Weather } \\
\text { conditions }\end{array}$ & Team \\
\hline \multirow{5}{*}{$5 / 2 / 2011$} & Field work Perparation & & \multirow{5}{*}{ Sawinggrai } & \multirow{5}{*}{ Sawinggrai } & \multirow{5}{*}{ Sunny } & \multirow{5}{*}{ John } \\
\hline & Submitted the Permit latter & & & & & \\
\hline & Accommodation & & & & & \\
\hline & Boat and driver arrangements & & & & & \\
\hline & Local Quid man & & & & & \\
\hline \multirow{2}{*}{$5 / 3 / 2011$} & Submitted the Permit latter & & \multirow{2}{*}{ Sawinggrai } & \multirow{2}{*}{ Sawinggrai } & \multirow{2}{*}{ Sunny } & \multirow{2}{*}{ John } \\
\hline & Boat and driver arrangements & & & & & \\
\hline \multirow{3}{*}{$5 / 4 / 2011$} & Field Work Training (theory) & & \multirow{3}{*}{ Wariprim } & \multirow{3}{*}{ Sawinggrai } & \multirow{3}{*}{ Sunny } & \multirow{3}{*}{$\begin{array}{l}\text { Mettu D., Niklaus S., Salma } \\
\text { M, John }\end{array}$} \\
\hline & Boat and driver arrangements & & & & & \\
\hline & Field Work Training (Practicum) & & & & & \\
\hline $5 / 5 / 2011$ & Mangroves and crab Observation & Low Tide & $\begin{array}{l}\text { it was delayed and changed } \\
\text { with field work preparation }\end{array}$ & Sawinggrai & Sunny & $\begin{array}{l}\text { Mettu D., Niklaus S., Salma } \\
\text { M, John }\end{array}$ \\
\hline
\end{tabular}




\begin{tabular}{|c|c|c|c|c|c|c|}
\hline $5 / 6 / 2011$ & Mangroves and crab Observation & Low Tide & Kapisawar & Gam Bay & Sunny & $\begin{array}{l}\text { Mettu D., Niklaus S., Salma } \\
\text { M, John }\end{array}$ \\
\hline $5 / 7 / 2011$ & Mangroves and crab Observation & Low Tide & Wariprim & Gam Bay & Sunny & $\begin{array}{l}\text { Mettu D., Niklaus S., Salma } \\
\text { M, John }\end{array}$ \\
\hline $5 / 08 / 2011$ & Mangroves and crab Observation & & & Sawinggrai & Sunny & \\
\hline $5 / 9 / 2011$ & Mangroves and crab Observation & Low Tide & Warbeki I & Gam Bay & Sunny & $\begin{array}{l}\text { Mettu D., Niklaus S., Salma } \\
\text { M, John }\end{array}$ \\
\hline $5 / 10 / 2011$ & Mangroves and crab Observation & Low Tide & Warbeki II & Gam Bay & Sunny & $\begin{array}{l}\text { Mettu D., Niklaus S., Salma } \\
\text { M, John }\end{array}$ \\
\hline $5 / 11 / 2011$ & Mangroves and crab Observation & Low Tide & Bun Iba & Gam Bay & Sunny & $\begin{array}{l}\text { Niklaus S., Salma M, Heji, } \\
\text { John }\end{array}$ \\
\hline $5 / 12 / 2011$ & Mangroves and crab Observation & Low Tide & Bun Iba & Gam Bay & Sunny & $\begin{array}{l}\text { Niklaus S., Salma M, Heji, } \\
\text { John }\end{array}$ \\
\hline $5 / 13 / 2011$ & Break & & & Sawinggrai & & \\
\hline $5 / 14 / 2011$ & Break & & & Sawinggrai & & \\
\hline $5 / 15 / 2011$ & Break & & & Sawinggrai/ Waisai & & \\
\hline $5 / 16 / 2011$ & Break & & & Waisai/Sawinggrai & & \\
\hline $5 / 17 / 2011$ & Mangroves and crab Observation & Low Tide & Warberen & It was canceled & Sunny & \\
\hline $5 / 18 / 2011$ & Mangroves and crab Observation & Low Tide & Taporpandera & Gam Bay & Sunny & $\begin{array}{l}\text { Jawi M, Persiel, Salma M, } \\
\text { John }\end{array}$ \\
\hline $5 / 19 / 2011$ & Mangroves and crab Observation & Low Tide & Taporpandera and Bun Mkun & Gam Bay & Sunny & Steven, Salma M., John \\
\hline $5 / 20 / 2011$ & Break & & Wariprim & Sawinggrai-Waisai & & \\
\hline $5 / 21 / 2011$ & Break & & Wariprim & Sawinggrai & & \\
\hline $5 / 22 / 2011$ & Break & & Wariprim & Sawinggrai & & \\
\hline $5 / 23 / 2011$ & Break & & Wariprim & Sawinggrai & & \\
\hline $5 / 24 / 2011$ & Evaluation and preparation & & Wariprim & Gam Bay & Reany & Nikolas S. \& John \\
\hline $5 / 25 / 2011$ & Searching the appropriate stations & Low Tide & $\begin{array}{l}\text { Warongkor, Warmanak, and } \\
\text { Waisirim }\end{array}$ & Gam Bay & Reany & Nikolas S., Mr. Albert S., John \\
\hline $5 / 26 / 2011$ & Searching the appropriate stations & Low Tide & Warberen & Gam Bay & Sunny & Nikolas S., John \\
\hline $5 / 27 / 2011$ & Searching the appropriate stations & Low Tide & Warberen & Gam Bay & Reany & Nikolas S., John \\
\hline $5 / 28 / 2011$ & Mangroves and crab Observation & Low Tide & Warberen & Gam Bay & Reany & Nikolas S., Salma M., John \\
\hline
\end{tabular}




\begin{tabular}{|c|c|c|c|c|c|c|}
\hline $5 / 29 / 2011$ & Break & & & Sawinggrai & & \\
\hline $5 / 30 / 2011$ & Mangroves and crab Observation & Low Tide & Warberen & Gam Bay & Reany, Cluody & Nikolas S., Salma M., John \\
\hline $5 / 31 / 2011$ & Mangroves and crab Observation & Low Tide & Warberen & Gam Bay & $\begin{array}{l}\text { Reany, Cluody, } \\
\text { Sunny }\end{array}$ & Nikolas S., Salma M., John \\
\hline 6/1/2011 & Mangroves and crab Observation & Low Tide & Bun Mngkun & Gam Bay & Reany, Sunny & Nikolas S., Salma M., John \\
\hline 6/2/2011 & Mangroves and crab Observation & Low Tide & Wariprim & Gam Bay & Sunny, Reany & Nikolas S. \& John \\
\hline 6/3/2011 & Mangroves and crab Observation & Low Tide & Kimfar & Gam Bay & $\begin{array}{l}\text { Sunny, Reany, } \\
\text { Claudy }\end{array}$ & Nikolas S., Salma M., John \\
\hline 6/4/2011 & Mangroves and crab Observation & Low Tide & Taporpandera, Bun Iba & Gam Bay & Sunny & Nikolas S., John \\
\hline 6/5/2011 & Mangroves and crab Observation & & Sawinggrai & Sawinggrai & Sunny & Nikolas S. \& John \\
\hline 6/6/2011 & Mangroves and crab Observation & Low Tide & Warmanak & Gam Bay & Sunny & Nikolas S., Salma M., John \\
\hline 6/7/2011 & Mangroves and crab Observation & Low Tide & Warongkor & Gam Bay & $\begin{array}{l}\text { Sunny and } \\
\text { claudy }\end{array}$ & $\begin{array}{l}\text { Nikolas S., Salma M., Calvin } \\
\text { Ronsumbre, John }\end{array}$ \\
\hline 6/8/2011 & Mangroves and crab Observation & Low Tide & Warbeki & Gam Bay & $\begin{array}{l}\text { Cloudy and } \\
\text { Reany }\end{array}$ & $\begin{array}{l}\text { Nikolas S., Salma M., Calvin } \\
\text { Ronsumbre, John }\end{array}$ \\
\hline 6/9/2011 & Mangroves and crab Observation & Low Tide & Warbeki & Gam Bay & $\begin{array}{l}\text { Cloudy and } \\
\text { Reany, Sunny }\end{array}$ & $\begin{array}{l}\text { Nikolas S., Salma M., Calvin } \\
\text { Ronsumbre, John }\end{array}$ \\
\hline 6/10/2011 & Mangroves and crab Observation & Low Tide & Kapisawar & Gam Bay & $\begin{array}{l}\text { Sunny and } \\
\text { claudy }\end{array}$ & Salma M., John \\
\hline 6/11-19/2011 & Evaluation & \multicolumn{2}{|c|}{ Final Evaluation } & \multicolumn{3}{|l|}{ Sawinggrai } \\
\hline 6/20/2011 & \multicolumn{6}{|l|}{ Time to go home } \\
\hline
\end{tabular}




\section{Mangrove trees Diversity in Raja Ampat and Gam Bay \\ a. Mangrove Diversity in Raja Ampat}

\begin{tabular}{|c|c|c|c|c|}
\hline No & Scientist Name & Famili & Indonesian Name & $\begin{array}{l}\text { Local Name (Biak } \\
\text { Language) }\end{array}$ \\
\hline 1 & Acanthus ebracteatus & Acanthaceae & Daruju & \\
\hline 2 & Acanthus ilicifolius & Acanthaceae & Daruju & \\
\hline 3 & Acrosticum speciosum & Pteridaceae & Paku laut & Mampenas \\
\hline 4 & Aegiceras corniculatum & Myrsinaceae & Jangkar tunggung & \\
\hline 5 & Aegiceras floridum & Myrsinaceae & Jangkar tunggung & \\
\hline 6 & Avicennia alba & Verbenaceae & Api-api & \\
\hline 7 & Avicennia lanata & Verbenaceae & Api-api & \\
\hline 8 & Avicennia marina & Verbenaceae & Api -api & \\
\hline 9 & Bruguiera gymnorrhiza & Rhizophoraceae & Jangkar kendeka & Ayuwom \\
\hline 10 & Bruguiera sexangula & Rhizophoraceae & Jangkar kendeka & Ayuwom \\
\hline 11 & Ceriops tagal & Rhizophoraceae & Jangkar tinggi & Pararus \\
\hline 12 & Excoecaria agallocha & Euphorbiaceae & Kayu buta-buta & \\
\hline 13 & Heritiera littoralis & Sterculiaceae & Cerlang laut & \\
\hline 14 & Lumnitzera racemosa & Combretaceae & Taruntun & \\
\hline 15 & Lumnitzera littorea & Combretaceae & Taruntun & \\
\hline 16 & Nypa fruticans & Arecaceae & Nipah & Caricis/Sanenem \\
\hline 17 & Rhizophora apiculata & Rhizophoraceae & Jangkar tanjang & Kor \\
\hline 18 & Rhizophora lamarckii & Rhizophoraceae & Jangkar tanjang & Kor \\
\hline 19 & Rhizophora mucronata & Rhizophoraceae & Jangkar tanjang & Kor \\
\hline 20 & Rhizophora stylosa & Rhizophoraceae & Jangkar tanjang & Kor \\
\hline 21 & Scyphiphora hydrophyllacea & Rubiaceae & & \\
\hline 22 & Sonneratia alba & Sonneratiaceae & Jangkar bogem & Suai/Tawawir \\
\hline 23 & Sonneratia caseolaris & Sonneratiaceae & Jangkar bogem & Suai/Tawawir \\
\hline 24 & Xylocarpus granatum & Meliaceae & Jangkar nyiri & Kabau/Awayu \\
\hline 25 & Xylocarpus moluccensis & Meliaceae & Jangkar nyiri & Kabau/Awa \\
\hline
\end{tabular}

Sources: The Nature Conservancy (2003)

\section{b. 15 Mangrove Species in Gam Bay}

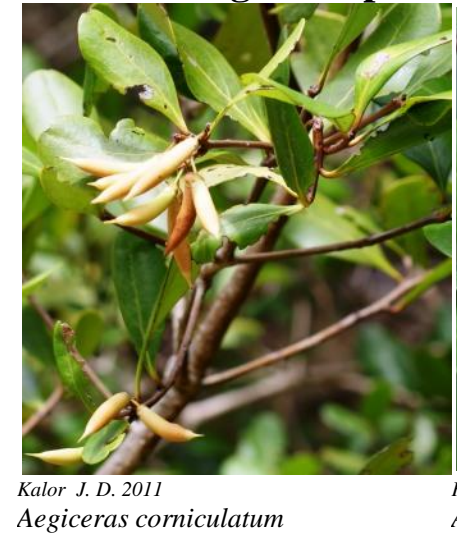

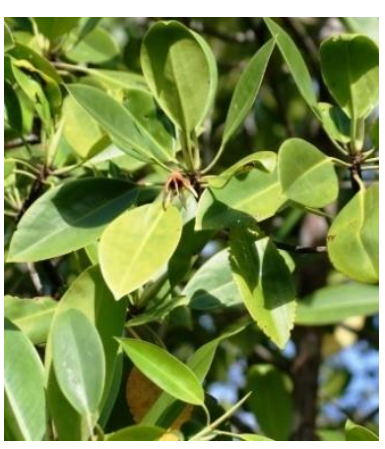

Kalor J. D. 2011 Bruguiera gymnorrhiza

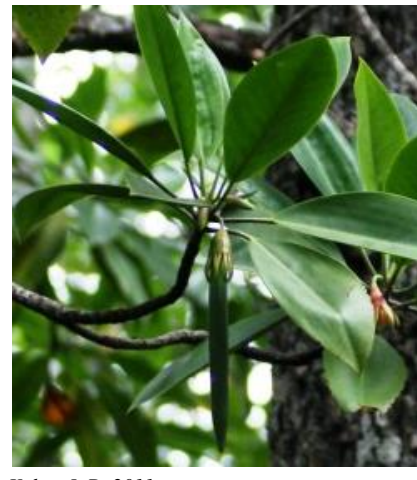

Kalor J. D. 2011

Bruguiera sexangula 


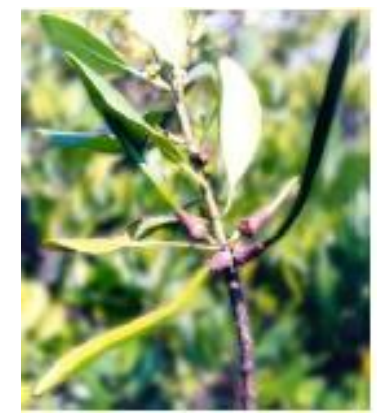

Ceriops decandra

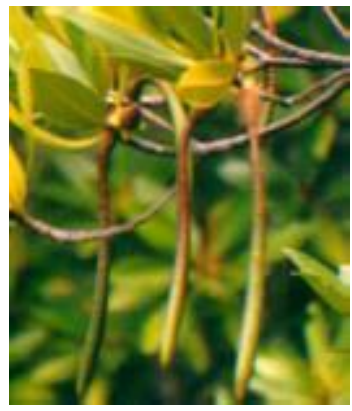

Rhizophora apiculata $\mathrm{BI}$

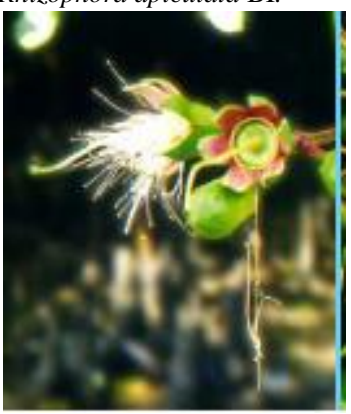

Sonneratia alba J.E. Smith

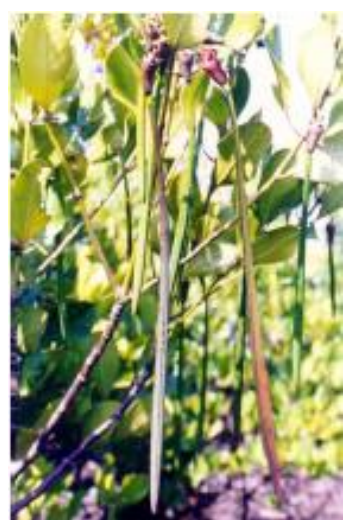

Ceriops tagal

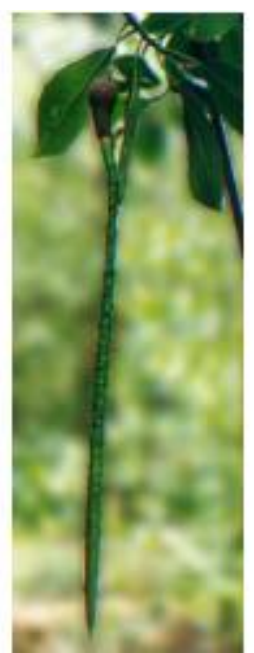

Rhizophora mucronata Lmk

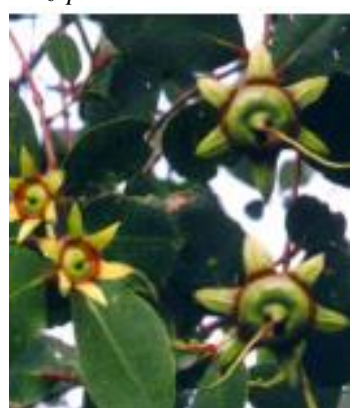

Sonneratia caseolaris (L.) Engl.

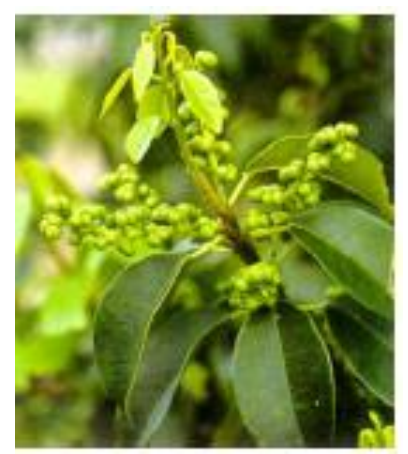

Excoecaria agallocha

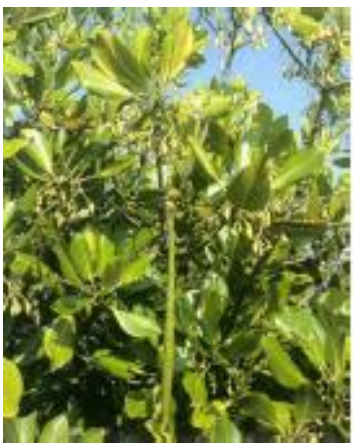

Rhizophora stylosa Griff

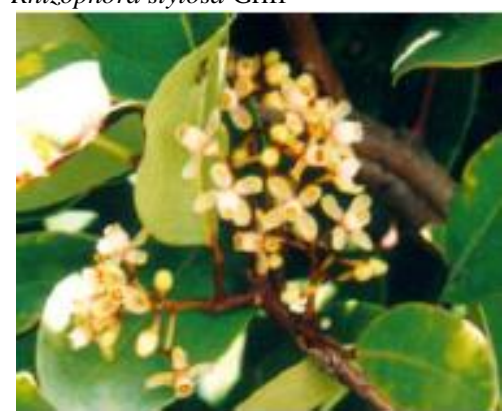

Xylocarpus granatum Koen

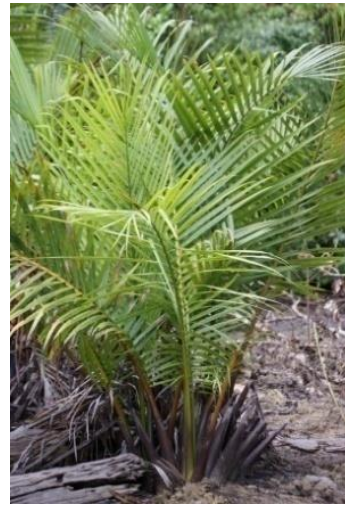

Kalor J. D. 2011

Nypa fruticans $\mathrm{W}$.

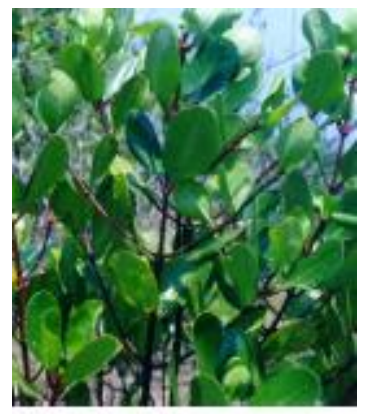

Scyphiphora hydrophyllacea 
3. Mangrove Crabs Diversity in Gam Bay 